Transport phenomena during nanofiltration of concentrated solutions

Gerrald Bargeman 
TRANSPORT PHENOMENA DURING NANOFILTRATION OF CONCENTRATED SOLUTIONS 


\section{Graduation committee:}

Prof. dr. ir. J.W.M. Hilgenkamp (Chairman) University of Twente

Prof. dr.-ing. M. (Matthias) Wessling (Promotor) University of Twente / RWTH Aachen

Prof. dr. ir. R.G.H. (Rob) Lammertink University of Twente

Prof. dr. ir. N.E. (Nieck) Benes University of Twente

Prof. dr. ir. D.C. (Kitty) Nijmeijer Eindhoven University of Technology

Prof. dr. ir. C.G.P.H. (Karin) Schroën Wageningen University

Dr. ir. F.P. (Petrus) Cuperus SolSep b.v.

Transport phenomena during nanofiltration of concentrated solutions

ISBN: 978-90-365-4195-4

DOI: $10.3990 / 1.9789036541954$

URL: http://dx.doi.org/10.3990/1.9789036541954

Printed by: Ipskamp Drukkers, Enschede

@ Copyright 2016 Gerrald Bargeman 


\title{
TRANSPORT PHENOMENA DURING NANOFILTRATION OF CONCENTRATED SOLUTIONS
}

\author{
DISSERTATION
}

to obtain

the degree of doctor at the University of Twente,

on the authority of the rector magnificus,

Prof. dr. H. Brinksma

on account of the decision of the graduation committee,

to be publicly defended

on Wednesday October 5, 2016 at 16:45 h

by

Gerrald Bargeman

born on May 4, 1962

at Groningen, The Netherlands 
This dissertation has been approved by the promotor:

Prof. dr.-ing. M. Wessling 


\section{Contents}

$\begin{array}{lr}\text { Summary } & 7\end{array}$

$\begin{array}{lll}\text { Chapter } 1 & \text { Introduction } & 17\end{array}$

Chapter $2 \quad$ Nanofiltration of multi-component feeds. Interactions between neutral and charged components and their effect on retention

Chapter 3

The effect of $\mathrm{NaCl}$ and glucose concentration on retentions for nanofiltration membranes processing concentrated solutions

Chapter 4

Nanofiltration as energy-efficient solution for sulfate waste in vacuum salt production

Chapter 5

The effect of membrane characteristics on nanofiltration membrane performance during processing of practically saturated salt solutions

Chapter 6

Conclusions and recommendations

Acknowledgement

Publications and

Patents

About the author 


\section{Summary}

In most scientific studies on nanofiltration either the development of new membrane materials or the characterization of membranes is reported. In the latter case most studies use single solute salt or sugar solutions and/or investigate nanofiltration of solutions with mixtures of ions at low concentrations relative to solution concentrations often used in industrial applications. Furthermore, several of these studies have tried to predict retention performance of nanofiltration membranes for salt solutions containing two different salts, on the basis of these characterization experiments and derived model parameters, often with limited success. Only limited knowledge is available in open literature on the effect of salt ions in an aqueous feed solution on retention of neutral solutes such as glucose and vice versa. A better insight in these phenomena is needed, since several nanofiltration applications treat solutions containing a combination of salts and (neutral) components such as sugars, amino acids, peptides or proteins. In addition, there has been limited attention in open literature for nanofiltration membrane performance during treatment of more concentrated salt solutions, such as depleted brine in chlor/alkali production and saturated brines in the production of salt crystals, despite the fact that a substantial amount of (potential) nanofiltration applications deals with these types of solutions. A better understanding of the phenomena occurring during nanofiltration of these types of solutions is a pre-requisite for proper design of membrane units for these types of applications. These research questions form the basis for the work presented in this thesis.

In Chapter $\mathbf{1}$ of this thesis a general introduction on nanofiltration is provided, followed by a brief overview of the models that are available to describe the transport through these membranes. A major part of this chapter focusses on nanofiltration applications for concentrated sodium chloride salt solutions ranging from sea water up to and including saturated salt solutions. In Chapter 2 the effect of different salts on the nanofiltration membrane characteristics based on glucose retention measurements is described and evaluated for several nanofiltration membrane types. Chapter 3 describes the extension of the concentration window to solutions nearly saturated in sodium chloride in combination with various glucose concentrations. Furthermore, the range of commercially available nanofiltration membrane types evaluated is extended. The effect of sodium chloride concentration on glucose retention and of glucose concentration on sodium chloride retention is studied, and is related to changes in 
membrane characteristics. Chapter 4 shows and discusses the feasibility of nanofiltration of salt solutions saturated in both sodium chloride and sodium sulfate to produce a retentate supersaturated in sodium sulfate and saturated in sodium chloride in combination with a permeate lean in sodium sulfate and saturated in sodium chloride. In Chapter $\mathbf{5}$ the knowledge base is extended to salt solutions saturated in sodium chloride containing significantly lower amounts of sodium sulfate. In this chapter thermodynamic considerations are used to explain the observations made in these chapters. Furthermore, a relation between sulfate and chloride retentions with membrane characterization results is discussed. Finally, Chapter 6 provides conclusions and recommendations from the research reported in this thesis.

The research presented in this thesis shows that for several commercially available nanofiltration membranes the addition of salt ions to a glucose solution can lead to a considerable reduction in glucose retention, even at low concentrations. The reduction in glucose retention is membrane specific, and furthermore depends on the retention of the salt ion added. A relatively low retention for the salt results in a stronger decrease in glucose retention. For addition of $\mathrm{NaCl}, \mathrm{CaCl}_{2}$, and $\mathrm{KCl}$ to the glucose solution, the retention drop appears to be a function of the chloride concentration in the permeate for the nanofiltration membranes Desal $5 D K$ and NF. This function is independent of the cation used. The observed effect is important for prediction of membrane performance during the demineralization of sugar solutions. However, it is not well described by a predictive model on the basis of the Maxwell-Stefan equation, which uses only pore size exclusion, Donnan exclusion, and average pore size to describe the separation process. The reduced glucose retention in the presence of salt can be described well when the pore radius value substituted in the model is increased at constant glucose radius. Several hypotheses are available to explain the observed phenomenon. One of these hypotheses is that the glucose retention reduction is caused by an increased effective average pore size, as a consequence of higher repulsion forces between the double layers in the pores when the concentration of ions and therefore the membrane charge as is predicted by the model, is increased. Another possible explanation is the presence of a pore size distribution. The Maxwell-Stefan model shows that the addition of salt with relatively low retention reduces the flux of the small pores to a higher extent than the larger pores. Thus the retention of glucose is determined to a larger extent by the larger pores and reduces when salt is added. This explains why in experiments where salts with low retention characteristics are present, the glucose retention drop is 
relatively large and a larger pore size estimate in the Maxwell-Stefan model is required to predict the glucose retention more accurately.

Extending the evaluated sodium chloride concentration range in the glucose solution to almost $300 \mathrm{~g}^{-\mathrm{L}^{-1}}$ (practically saturated solutions) and extending the window of nanofiltration membrane types investigated, shows that the glucose retention for a solution containing $1 \mathrm{~g} . \mathrm{L}^{-1}$ glucose decreases strongly when the sodium chloride concentration is increased from $0 \mathrm{~g} \cdot \mathrm{L}^{-1}$ to $100 \mathrm{~g} \cdot \mathrm{L}^{-1}$, when compared at similar flux. However, a further increase in sodium chloride concentration results in only minor further reduction of the glucose retentions. This means that the effect of adding salt to the glucose solution stabilizes at higher salt concentration. As for the earlier reported results a change in the pore radius at assumed constant glucose radius or alternatively a change in the ratio of glucose molecular radius over the membrane effective pore radius explains the obtained results.

At very high glucose (of around $80 \mathrm{~g} . \mathrm{L}^{-1}$ ) and sodium chloride (in excess of $175 \mathrm{~g} . \mathrm{L}^{-1}$ ) concentrations in the feed solution, a sodium chloride retention of around 0 is obtained for all nanofiltration membranes evaluated. The presence of glucose has a minor 'salting-out' effect on sodium chloride, leading to slightly negative sodium chloride retentions for high glucose concentration differences between retentate and permeate. For all membranes evaluated, mean pore radii and effective membrane thicknesses have been determined. The obtained parameters can be used to facilitate the development of nanofiltration applications for desalination of concentrated glucose solutions in industry and to get a feel for changing membrane characteristics for solutions with high salt concentrations.

Nanofiltration of brines saturated in not only sodium chloride, but in sodium sulfate as well has been studied. The use of nanofiltration for concentrating these brines and producing a retentate which is supersaturated in sodium sulfate is shown to be technically feasible and an attractive alternative for evaporative or cooling concentration. Crystallization of sodium sulfate in the membrane modules can be avoided by the presence of a primary nucleation inhibitor in the feed to the nanofiltration unit. Sodium sulfate crystallization can be induced in a separate crystallizer outside of the membrane unit by addition of crystal seeds. Chloride and bromide retentions are negative and they are a function of the difference in sulfate concentration between 
concentrate and permeate. Carbonate retentions are linearly dependent on sulfate retentions. Calcium retention for NF270 is in excess of $95 \%$ and proven to be stable during 1200 hours of continuous operation. The same applies for the potassium retention albeit at a lower level of $10 \%$.

During nanofiltration of salt solutions practically saturated in sodium chloride, but sodium sulfate concentrations far below saturation, the sulfate retention can be estimated from the mean pore radius of the nanofiltration membrane as determined from simple characterization experiments. For all nanofiltration membranes, ranging from tight to relatively open, the sulfate retention obtained for nanofiltration of these salt solutions is lower than that obtained during characterization experiments with a single salt sodium sulfate solution at similar sulfate concentration. This reduction is ascribed to the presence of sodium chloride in the solution causing a lower sulfate radius over mean pore radius at high ionic strength of the solution and possibly reduced Donnan exclusion. As a first estimate, the chloride retention of the nanofiltration membranes for processing of practically saturated salt solutions, irrespective of the openness of the nanofiltration membrane, can be obtained from the difference in sulfate concentration between concentrate (retentate) and permeate, irrespective of the sulfate concentration in the feed solution. This difference in sodium sulfate concentration between retentate and permeate can be obtained from the sulfate retention and therefore indirectly from the mean pore radius obtained from characterization experiments. The fact that this correlation between chloride retention and the difference in sulfate concentration between retentate and permeate is practically independent of the membrane type used, is caused by the low resistance of the membrane for sodium chloride transport and the negligible difference between activity coefficients for sodium chloride in retentate and permeate, as indicated by thermodynamic considerations.

The results obtained and reported in this thesis consequently provide a comprehensive insight in the effect of salt ions on glucose retention and vice versa, during processing of solutions containing both components. Furthermore, they have led to improved insight in the transport process through the nanofiltration membranes. In addition, nanofiltration of saturated salt solutions has been shown to be feasible. Even nanofiltration using solutions super-saturated in a soluble salt such as sodium sulfate is shown to be possible. During nanofiltration of these solutions retentates and permeates practically saturated in sodium chloride are obtained. Sulfate and chloride retentions for 
nanofiltration membranes can furthermore be determined from a simple membrane characterization method and thermodynamic considerations. 


\section{Samenvatting}

In de meeste wetenschappelijke studies naar nanofiltratie wordt de ontwikkeling van nieuwe membraanmaterialen of de karakterisering van membranen beschreven. In het laatste geval wordt in de meeste studies gebruik gemaakt van een zout- of suikeroplossing en/of van een oplossing van een ionenmengsel in een laag concentratiegebied ten opzichte van de concentraties die vaak voorkomen in industriële applicaties. Verder zijn er, meestal met beperkt succes, verscheidene studies beschikbaar waarin is geprobeerd om het retentiegedrag van nanofiltratiemembranen voor zoutoplossingen die twee verschillende zouten bevatten, te voorspellen op basis van deze karakteriseringsexperimenten en daaruit bepaalde modelparameters. In de openbare literatuur is er tevens weinig informatie te vinden over het effect van zoutionen in een waterige oplossing op de retentie van ook aanwezige neutrale opgeloste componenten zoals glucose, en omgekeerd. Een beter inzicht in deze fenomenen is noodzakelijk, aangezien verscheidene nanofiltratie toepassingen voedingsstromen behandelen, die een combinatie van zouten en (neutrale) componenten, zoals suikers, aminozuren, peptiden of proteïnen, bevatten. Tevens is er in de openbare literatuur beperkt aandacht voor het gedrag van nanofiltratiemembranen gedurende de behandeling van meer geconcentreerde zoutoplossingen, zoals uitgeputte pekelstromen in chloor/loog-productie en verzadigde pekelstromen in de productie van vast zout, ondanks het feit dat een substantieel deel van de (potentiele) nanofiltratie toepassingen dit type oplossingen behandelt. Een beter begrip van de fenomenen die gedurende het nanofiltratie proces met dit type oplossingen optreden, is een voorwaarde voor een goed ontwerp van membraaninstallaties voor dit soort applicaties. Deze onderzoeksvragen vormen de basis voor het werk dat in dit proefschrift wordt gepresenteerd.

In Hoofdstuk 1 van dit proefschrift wordt een algemene introductie over nanofiltratie beschreven, gevolgd door een kort overzicht van de modellen die beschikbaar zijn om het transport door deze membranen te beschrijven. Een groot deel van dit hoofdstuk legt de nadruk op nanofiltratie toepassingen met geconcentreerde op natriumchloride gebaseerde zoutoplossingen, variërend van zeewater tot en met verzadigde zoutoplossingen. In Hoofdstuk 2 wordt het effect van verschillende zouten op de nanofiltratiemembraan kenmerken gebaseerd op glucoseretentie metingen beschreven en geëvalueerd voor verscheidene nanofiltratiemembraan types. Hoofdstuk 3 beschrijft 
de extensie van het concentratiebereik naar oplossingen die vrijwel verzadigd zijn in natriumchloride in combinatie met verschillende glucoseconcentraties. Verder wordt het bereik van geëvalueerde commercieel beschikbare nanofiltratiemembraan types uitgebreid. Het effect van de natriumchlorideconcentratie op de glucoseretentie en van de glucoseconcentratie op de natriumchlorideretentie wordt bestudeerd, en wordt gerelateerd aan veranderingen in membraankarakteristieken. Hoofdstuk 4 toont en bespreekt de haalbaarheid van nanofiltratie van zoutoplossingen die verzadigd zijn in zowel natriumchloride als natriumsulfaat, waarbij een retentaat oververzadigd in natriumsulfaat en verzadigd in natriumchloride wordt geproduceerd in combinatie met een permeaat dat verzadigd is in natriumchloride en dat vrijwel geen natriumsulfaat bevat. In Hoofdstuk 5 wordt de kennisbasis uitgebreid naar nanofiltratie van zoutoplossingen verzadigd in natriumchloride met significant lagere natriumsulfaatconcentraties. In dit hoofdstuk worden thermodynamische beschouwingen gebruikt om de observaties die zijn gedaan in deze laatste hoofdstukken te verklaren. Verder wordt een relatie tussen sulfaat- en chlorideretenties met membraankarakteriseringresultaten besproken. Tot slot bevat Hoofdstuk 6 conclusies en aanbevelingen uit het onderzoek dat in dit proefschrift wordt gerapporteerd.

Het in dit proefschrift gepresenteerde onderzoek laat zien dat voor verschillende commercieel beschikbare nanofiltratiemembranen de toevoeging van zoutionen aan een glucoseoplossing kan leiden tot een substantiële verlaging van de glucoseretentie, zelfs al bij lage zoutconcentraties. De verlaging in glucoseretentie is membraan specifiek en hangt verder af van de retentie van het toegevoegde zout ion. Een relatief lage retentie van het zout resulteert in een sterkere verlaging van de glucoseretentie. Voor toevoeging van $\mathrm{NaCl}, \mathrm{CaCl}_{2}$, of $\mathrm{KCl}$ aan de glucoseoplossing, blijkt de retentiedaling een functie van de chlorideconcentratie in het permeaat te zijn voor de nanofiltratiemembranen Desal $5 D K$ en NF. Deze functie is onafhankelijk van het gebruikte cation. Het waargenomen effect is belangrijk voor de voorspelling van het membraangedrag gedurende de ontzouting van suikeroplossingen. Echter, dit gedrag wordt niet goed beschreven door een voorspellend model op basis van de MaxwellStefan vergelijking, dat alleen gebruik maakt van poriegrootte-exclusie, Donnanexclusie, en een gemiddelde poriegrootte om het scheidingsproces te beschrijven. De gereduceerde glucoseretentie in aanwezigheid van zout kan wel goed worden beschreven wanneer de in het model gesubstitueerde poriestraal wordt verhoogd onder 
aanname van een constante glucoseradius. Verschillende hypotheses zijn beschikbaar om dit geobserveerde gedrag te verklaren. Een van deze hypotheses is dat de afname van de glucoseretentie wordt veroorzaakt door de verhoogde effectieve gemiddelde poriegrootte, die ontstaat als consequentie van grotere afstotingskrachten tussen de dubbellagen in de poriën wanneer de ionenconcentratie en dientengevolge de membraanlading (zoals voorspeld door het model) wordt verhoogd. Een andere mogelijke verklaring is de aanwezigheid van een poriegrootte distributie. Het MaxwellStefan model laat zien dat de toevoeging van een zout met een relatief lage retentie de flux in de kleine poriën sterker reduceert dan die in de grotere poriën. Daarom wordt de glucoseretentie sterker door de grotere poriën bepaald en gereduceerd wanneer er zout wordt toegevoegd. Dit verklaard waarom in experimenten waar zout met lage retentiekarakteristieken aanwezig is, de glucoseretentie relatief sterk daalt en een grotere poriegrootte nodig is in het Maxwell-Stefan model om de glucoseretentie nauwkeuriger te voorspellen.

Uitbreiding van het bestudeerde natriumchloride concentratiegebied in de glucose oplossing tot bijna $300 \mathrm{~g} . \mathrm{L}^{-1}$ (een vrijwel verzadigde oplossing) en uitbreiding van het aantal onderzochte nanofiltratiemembraan types, laat zien dat de glucoseretentie voor een oplossing die 1 g. $\mathrm{L}^{-1}$ glucose bevat sterk daalt wanneer de natriumchlorideconcentratie wordt verhoogd van $0 \mathrm{~g} \cdot \mathrm{L}^{-1}$ tot $100 \mathrm{~g} \cdot \mathrm{L}^{-1}$, vergeleken bij dezelfde flux. Echter, een verdere verhoging van de natriumchlorideconcentratie resulteert in slechts een beperkte verdere verlaging van de glucoseretentie. Dit betekent dat het effect van het toevoegen van zout aan de glucoseoplossing stabiliseert bij hogere zoutconcentraties. Net zoals bij eerder gerapporteerde resultaten verklaart een verandering van de poriestraal, onder aanname dat de glucosestraal onveranderd is gebleven, of als alternatief, een verandering van de ratio van de glucosestraal over de effectieve poriestraal van het membraan, de verkregen resultaten.

$\mathrm{Bij}$ zeer hoge glucose- (van ongeveer $80 \mathrm{~g} . \mathrm{L}^{-1}$ ) en natriumchlorideconcentraties (groter dan $\left.175 \mathrm{~g} . \mathrm{L}^{-1}\right)$ in de voedingsoplossing, wordt een natriumchlorideretentie van ongeveer 0 verkregen voor alle geëvalueerde nanofiltratiemembranen. De aanwezigheid van glucose heeft een beperkt 'salting-out' effect op natriumchloride. Dit leidt tot licht negatieve natriumchlorideretenties voor grote verschillen tussen de glucoseconcentratie in het retentaat en het permeaat. Voor alle geëvalueerde membranen, zijn gemiddelde poriestralen en effectieve membraandiktes bepaald. De verkregen parameters kunnen 
worden gebruikt om de ontwikkeling van nanofiltratie toepassingen voor ontzouting van geconcentreerde glucoseoplossingen in de industrie te faciliteren en om een gevoel te krijgen voor de veranderende membraankarakteristieken voor oplossingen met hoge zoutconcentraties.

Nanofiltratie van pekeloplossingen die niet alleen verzadigd zijn in natriumchloride maar tevens in natriumsulfaat, is eveneens onderzocht. $\mathrm{Er}$ is aangetoond dat het gebruik van nanofiltratie voor het concentreren van deze pekelstromen en het produceren van een retentaat oververzadigd in natriumsulfaat niet alleen technisch haalbaar is, maar ook een attractief alternatief is voor indampen en koelconcentratie. Kristallisatie van natriumsulfaat in de membraanmodules kan worden voorkomen door de aanwezigheid van een primaire nucleatieremmer in de voeding naar de nanofiltratie installatie. Kristallisatie van natriumsulfaat kan worden geïnitieerd in een gescheiden kristallisatiestap buiten de membraaninstallatie door toevoeging van ent-kristallen. Chloride- en bromideretenties zijn negatief en zijn een functie van het verschil tussen de sulfaatconcentratie in het concentraat en in het permeaat. De verkregen carbonaatretenties zijn lineair afhankelijk van de sulfaatretenties. De calciumretentie voor NF270 is hoger dan $95 \%$ en stabiel gedurende 1200 uur van continue operatie. Voor de kaliumretentie geldt hetzelfde, maar op een lager niveau (van 10\%).

Gedurende nanofiltratie van zoutoplossingen die vrijwel verzadigd zijn in natriumchloride, maar sterk onderverzadigd in natriumsulfaat, kan de sulfaatretentie worden geschat uit de gemiddelde poriestraal van het nanofiltratiemembraan zoals bepaald uit simpele karakteriseringsexperimenten. Voor alle nanofiltratiemembranen, van dicht tot relatief open, is de verkregen sulfaatretentie voor nanofiltratie van deze zoutoplossingen lager dan de sulfaatretentie die verkregen is tijdens karakteriseringsexperimenten met een zoutoplossing met alleen natriumsulfaat (bij dezelfde natriumsulfaatconcentratie). Deze verlaging wordt toegeschreven aan de aanwezigheid van natriumchloride in de oplossing die leidt tot een lagere ratio van de sulfaatstraal over de gemiddelde poriestraal bij hoge ionsterkte van de oplossing en mogelijkerwijs gereduceerde Donnan-exclusie. Als eerste schatting kan de chlorideretentie van de nanofiltratiemembranen voor het behandelen van praktisch verzadigde zoutoplossingen, onafhankelijk van de openheid van het nanofiltratiemembraan en de sulfaatconcentratie in de voedingsoplossing, verkregen worden uit het verschil tussen de sulfaatconcentratie van het concentraat (retentaat) en 
het permeaat. Dit verschil tussen de sulfaatconcentratie van het retentaat en het permeaat kan worden verkregen uit de sulfaatretentie en daarom indirect uit de gemiddelde poriestraal verkregen uit karakteriseringsexperimenten. Het feit dat deze correlatie tussen chlorideretentie en het verschil tussen de sulfaatconcentratie van het retentaat en het permeaat praktisch onafhankelijk is van het gebruikte membraantype wordt veroorzaakt door de lage weerstand van het membraan voor natriumchloridetransport en het verwaarloosbare verschil tussen de activiteitscoëfficiënten voor natriumchloride in het retentaat en het permeaat, zoals blijkt uit thermodynamische beschouwingen.

De resultaten verkregen en gerapporteerd in dit proefschrift geven een compleet inzicht in het effect van zoutionen op glucoseretentie en vice versa, gedurende het behandelen van oplossingen die beide componenten bevatten. Verder, hebben ze geleid tot een verbeterd inzicht in de transportprocessen door nanofiltratiemembranen. Daarnaast is aangetoond dat nanofiltratie van verzadigde zoutstromen mogelijk is. Zelfs nanofiltratie waarin oplossingen ontstaan die oververzadigd zijn in oplosbare zouten zoals natriumsulfaat, blijkt haalbaar te zijn. Gedurende nanofiltratie van deze oplossingen worden retentaten en permeaten verkregen die vrijwel verzadigd zijn in natriumchloride. Sulfaat- en chlorideretenties voor nanofiltratiemembranen kunnen verder worden bepaald uit een simpele membraankarakteriseringsmethode en thermodynamische beschouwingen. 


\section{Chapter 1}

\section{Introduction}

Parts of this chapter have been published in:

G. Bargeman, Separation technologies to produce dairy Ingredients, Chapter 17 in Dairy Processing. Improving Quality, Editor, G. Smit, (2003), 366-390, Woodhead Publishing Limited, Cambridge, UK.

G. Bargeman, M. Timmer, C. van der Horst, Nanofiltration in the food industry, Chapter 12 in Nanofiltration - Principles and Applications $1^{\text {st }}$ edition, Eds. A.I. Schaefer, A.G. Fane and T. D. Waite, (2005), 305-328, Elsevier Advanced Technologies, Oxford, UK. 


\section{The role of membrane technology in industry as alternative for thermal separations}

In the oil, chemical and food industries, product concentration and the separation from by-products and/or impurities consume high amounts of energy. Most of the processes in these industries use distillation or evaporation to separate or concentrate the obtained products. These thermal separation technologies intrinsically have low thermodynamic efficiencies [1]. However, as a consequence of technological developments, distillation and evaporation processes are nowadays operated closer to the minimal energy requirements for the separation of the product mixtures into the individual components based on thermodynamics. These thermal separation technologies are more and more intensified, e.g. through the use of multi-effect vapor recompression systems to re-use produced vapors as heat source [2, 3], dividing wall columns to increase energy efficiency in multi-product separation [4], heat pumps to allow upgrading and optimal use of available (waste) heat $[5,6]$, or the addition of components that affect the relative volatility between the products to be separated (e.g. in extractive distillation) $[7,8]$. Despite these improvements the use of distillation alone still accounts for approximately $50 \%$ of the energy consumption and the investment costs required for processes in the chemical and oil industries [9], and new developments of the thermal separation and alternative technologies are needed to further reduce energy consumption of separation processes in the near future. Membrane technology is one of the separation technologies which have the potential to contribute to this further reduction in energy demand (e.g. [10, 11]).

Membranes have been implemented in industry from the late 1960s on [12], and have played a major role in the production of water, dairy products, chemicals, oil and pharmaceuticals ever since. The amount of membrane surface area implemented in the industry has grown significantly in the $20^{\text {th }}$ century, as illustrated for the ultrafiltration membrane surface area installed in the dairy industry $[13,14]$ in Figure 1. In the same time frame $80,000 \mathrm{~m}^{2}$ reverse osmosis membrane surface area has been implemented in the dairy industry $[13,14]$. At present, new membrane applications are still being developed and implemented in industrial applications. Generally, membranes are used for processing of aqueous streams, but membranes are being used for separation of solvent streams as well (e.g. $[13,15])$. 


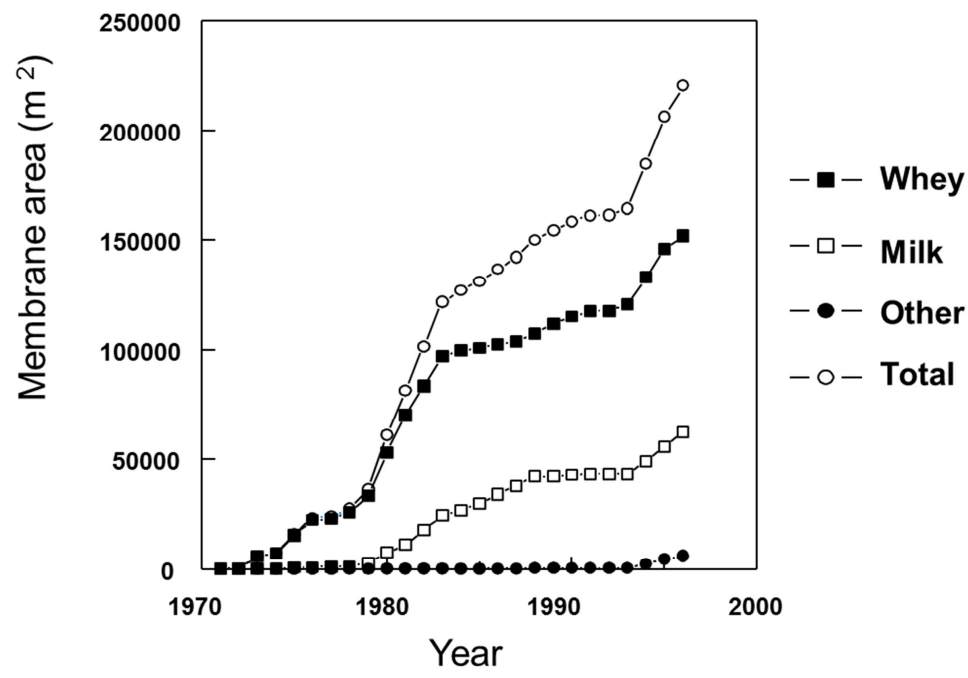

Figure 1: Implemented ultrafiltration membrane surface area in the dairy industry from $1970-1995[13,14]$.

\section{Description of membrane technologies}

Membrane processes used for concentration or the separation of products can make use of different driving forces. These driving forces include [16]:

- $\quad$ pressure differences (for pressure driven membrane technology)

- partial pressure differences (for pervaporation, membrane distillation, and membrane degassing)

- electrical potential differences (for electro-dialysis for desalting or separation of charged from neutral components, bi-polar membrane electro-dialysis, electromembrane filtration and membrane electrolysis for chlor/alkali products)

- activity differences (e.g. for diffusion dialysis and gas separation)

- temperature differences (e.g. for thermo-osmosis)

The studies reported in this thesis focus on pressure driven membrane technology. This membrane technology area consists of four distinct membrane types called reverse osmosis, nanofiltration, ultrafiltration and microfiltration. The characterization of the different types is mainly based on the tightness of the membrane, identified by the 
retention of specific molecules by the membrane. The four categories are illustrated for their retention characteristics of dairy and salt feed component streams in Figure 2.

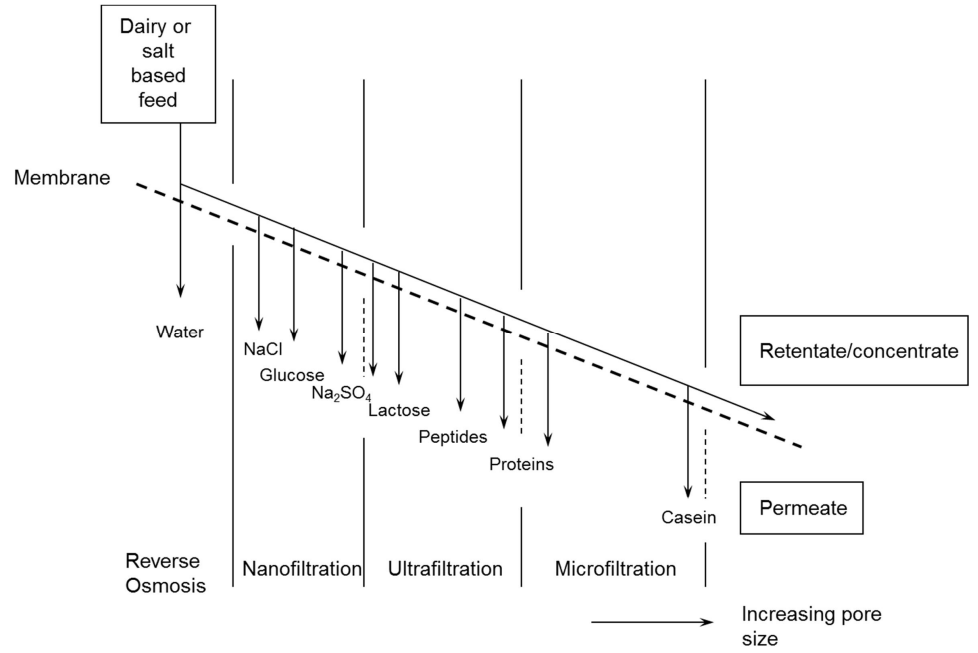

Figure 2: Schematic representation for typical passage of water and solutes through the pressure driven membrane technologies microfiltration, ultrafiltration, nanofiltration and reverse osmosis.

There are no uniform definitions for the four categories, but often the molecular weight cut-off (MWCO) of the membrane is used to define the different categories. According to the commonly used definition the MWCO is equal to the molecular weight of the solute that is retained by the membrane for $90 \%$ [17-19]. Alternatively, the membrane is categorized through the pore size of the membrane. Often the problem of membrane characterization lies in the difficulty that not only the membrane resistance determines separation, but the mass transport at the membrane/fluid interface as well. The latter strongly depends on geometrical and process parameters. It should be noted that despite several efforts to harmonize characterization methods, such as conducted in the European project CHARME [20], there are still no standardized tests commonly used for the determination of the MWCO. This means that specific membranes from different membrane suppliers can show similar membrane characteristics, despite the fact that these membrane suppliers quote a different MWCO for these membranes [19]. A typical membrane characteristic for the different membrane categories for pressure driven membrane technology can be found in Table 1. 
Table 1: Definition of pressure driven membrane categories as function of molecular weight cut-off and pore size.

\begin{tabular}{ccc}
\hline Category & $\begin{array}{c}\text { Molecular weight cut-off range } \\
(\mathrm{Da})\end{array}$ & $\begin{array}{c}\text { Pore size } \\
(\mu \mathrm{m})\end{array}$ \\
\hline Reverse Osmosis & $<200$ & \\
Nanofiltration & $200-1000$ & \\
Ultrafiltration & $1000-250,000$ & $>0.1$ \\
Microfiltration & & \\
\hline
\end{tabular}

\section{Description of nanofiltration membrane technologies}

The studies discussed in this thesis focus specifically on nanofiltration membrane technology. As can be seen from Table 1 and Figure 2, nanofiltration is especially suitable to permeate water and to separate relatively small ions and organic molecules from bigger ions or organic molecules. The separation characteristics of nanofiltration membranes will be discussed in more detail later in this chapter.

Nanofiltration membranes can consist of polymeric and/or ceramic materials. Even though there are strong developments in the production of ceramic membrane materials (e.g. [21]) and polymer grafted ceramic membranes (e.g. [22]) especially for the processing of feed streams at high temperature or the processing of solvent streams which require chemically stable membrane modules, commonly polymeric nanofiltration membranes are used in industry. These polymeric membranes are either asymmetric membranes or thin film composite membranes on an ultrafiltration type support (see e.g. [23-25]). Typical polymers used include polyamide, polyimide, (sulfonated) polyether sulfone, sulfonated polyether ether ketone, and (originally) cellulose acetate. Supports often consist of (sulfonated) polyether sulfone, cellulose acetate or polyacrylonitrile. However, there are many other polymeric materials or hybrid materials, such as ultrathin polyhedral silsesquioxane - polyamide layers [26], used or under investigation as well. The selection of the proper membrane type and membrane material depends on the composition of the solution processed and the temperature and pressure used during nanofiltration operation. For processing of aqueous solutions 
a relatively hydrophilic membrane material usually has clear benefits over the use of very hydrophobic membrane material, since the use of the latter material will usually lead to relatively low permeability at the same membrane pore size [27] and stronger membrane fouling by organic molecules due to better adsorption of these molecules on the surface of the membrane [28]. Furthermore, chemical stability of the membrane material becomes more important for operation with organic solvents, aqueous streams with an extreme $\mathrm{pH}$ ( $<2$ or $>10$ ), or for feed solutions containing oxidizing agents.

In the studies reported in this thesis only commercially available polymeric nanofiltration membranes have been used. This has clear advantages when the obtained knowledge needs to be used for the development of commercial applications, however, the disadvantage is that the exact composition of the membrane material is usually not known, which might make interpretation of results a bit more difficult.

\section{Available models to support development of nanofiltration membrane applications}

As stated earlier, nanofiltration is suitable for the concentration of liquid streams and the separation of relatively small ions and organic molecules from bigger molecules. For the development of nanofiltration applications it is important that suitable models are available to support and speed up the development of such applications. To describe the separation in nanofiltration processes, several models are available in open literature. Models most commonly used to describe nanofiltration processes are [29]:

- the homogeneous solution diffusion model

- the Spiegler-Kedem model

- the irreversible thermodynamic equations of Kedem-Katchalsky

- the (extended) Nernst-Planck model

- the Maxwell-Stefan model

The Spiegler-Kedem model and Kedem-Katchalsky equations based model originate historically from modelling of reverse osmosis processes [29, 30]. In these models the membrane is treated like a black box. Consequently, characterization of structural and electrical properties is not possible using these models. On the other hand, the extended Nernst-Planck and Maxwell-Stefan models were introduced simultaneously 
with the advent of nanofiltration to describe the transport of components through the membrane via sieving and electrical mechanisms [30], which are more suitable to describe ultrafiltration processes. Identification of the model that describes the nanofiltration process most accurately has been subject to intensive debates during the last decades, and despite numerous efforts has not been fully unraveled yet. The discussion on this debate is outside of the scope of the work reported in this thesis, although modelling of the obtained experimental results is done to improve (fundamental) understanding of the nanofiltration separation process and to describe membrane characteristics. As suggested by Bowen and Welfoot [30] the challenge is to develop models that convey a fundamental understanding and simple qualification of the governing phenomena in a way that has potential for industrial applications. This means that it is important to use models 'fit for purpose'. Since for nanofiltration of aqueous streams as studied in this thesis it is important to obtain insight in structural aspects of the membranes evaluated, and the extended Nernst-Planck and MaxwellStefan based models are most commonly used to describe these membrane characteristics (the sieving effect and charge interaction effects of the membrane with the solutes), these models have been used to describe and explain observed nanofiltration results.

For the Nernst-Planck and Maxwell-Stefan model several membrane characteristics are required for proper description of the transport of solutes through the nanofiltration membrane. More detailed information about these models can be obtained from [3032]. Usually, single salt solutions and single sugar solutions with concentrations in the range of $10^{-3}-10^{-1} \mathrm{M}$ are used to determine these characteristics. Although obtaining the membrane characteristics is relatively straightforward, predicting the retention characteristics of mixed salt solutions on the basis of these characteristics is not [31]. For example, limited attention has been paid in open literature to the interaction between salt ions and neutral components such as sugars, during transport of these components through nanofiltration membranes, even though many (potential) applications of nanofiltration deal with solutions consisting of multiple salt and sugar mixtures. Consequently, a better fundamental insight in the interaction between salt and sugar transport through nanofiltration membranes is needed to assist implementation of new membrane systems in industry. This does not only apply to nanofiltration of dilute solutions, but to processing of more concentrated solutions as well. 


\section{Applications of nanofiltration systems in industry}

Nanofiltration is widely applied in industry [33], with the water, food and chemical industries as main industrial sectors. Applications include the production of drinking water and process water [34, 35], the desalination of cheese whey, sugar beet thin juice and carboxymethylinulin (CMI) [13], the concentration of glucose syrup [13], the treatment of sea water and depleted brine from the chlor/alkali production process [36], and processing of textile dye solutions [37] and pulp and paper industry waters [38]. In most of these applications the solution supplied to the nanofiltration unit consists of a combination of ions and/or a combination of neutral solutes and ions. Furthermore, the concentrations of the solutes are relatively high, at least higher than the solute concentration normally used in nanofiltration membrane characterization experiments. One of the important applications areas for nanofiltration membranes is in treating solutions containing mixtures of sodium sulfate and sodium chloride as mainly present in sea water, depleted brine in the chlor/alkali industry and brine in the salt production industry. These applications are discussed in more detail in the next section since the separation of sulfate and chloride is one of the main topics of the research reported in this thesis.

\section{Nanofiltration for processing of sodium chloride brines}

Nanofiltration membranes are characterized by a molecular weight cut-off between 200 $\mathrm{Da}$ and $1000 \mathrm{Da}$. Therefore these membranes are especially suitable for the separation of mono-valent ions from multivalent ions and/or organic solutes as mentioned earlier. One of the commonly studied and industrially used applications of nanofiltration is the separation of sulfates from chlorides. Most studies reported in open literature focus on the separation of mono-valent anions from multivalent anions at relatively low concentrations. However, most industrial applications commonly deal with the processing of more concentrated solutions. Examples of such solutions in order of increasing sodium chloride concentration are seawater (typically $30 \mathrm{~g} \cdot \mathrm{L}^{-1} \mathrm{NaCl}$ ), reverse osmosis retentate from seawater desalination (around $40-70 \mathrm{~g} \cdot \mathrm{L}^{-1} \mathrm{NaCl}$ ), depleted brines from chlor/alkali production (ranging from $150-200 \mathrm{~g} \cdot \mathrm{L}^{-1} \mathrm{NaCl}$ ), and practically saturated brines in sodium chloride crystalline salt production (around $300 \mathrm{~g} \cdot \mathrm{L}^{-1} \mathrm{NaCl}$ ). 


\subsection{Production of low sulfate containing seawater for oil and gas stimulation}

Nanofiltration of raw seawater is commonly used on off-shore oil and gas platforms (see Fig. 3). Water is needed for stimulation of oil and gas recovery. However, fresh water is not abundantly available at these platforms, whereas seawater is. Even though the presence of typically $30 \mathrm{~g} \cdot \mathrm{L}^{-1}$ sodium chloride in the (sea) water is not a strong disadvantage for the use of seawater, the presence of contaminants such as calcium, barium, strontium and especially sulfate is [39].

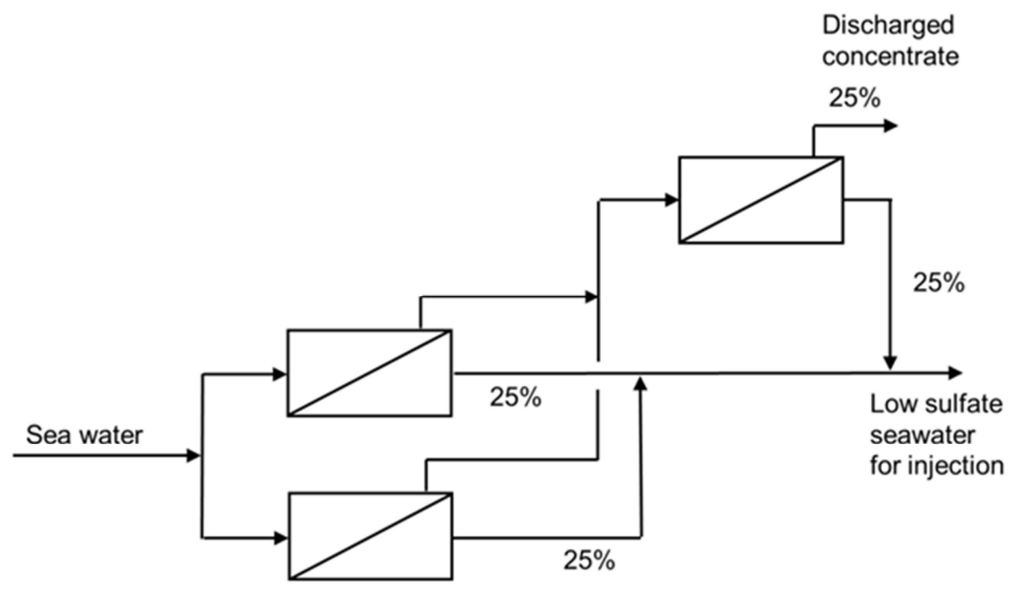

Figure 3: Schematic representation of nanofiltration for production of low sulfate containing injection water for stimulating off-shore oil recovery.

To avoid the disadvantages of the use of seawater, nanofiltration membranes are used to produce permeate with low contaminants concentrations, which can be safely injected into the well. Sulfate concentrations are claimed to be reduced from typically $2800 \mathrm{mg} \cdot \mathrm{L}^{-1}$ to less than $50 \mathrm{mg} \cdot \mathrm{L}^{-1}$ [40], indicating that sulfate retention is in excess of $98 \%$. Sodium chloride retentions are only marginally positive, meaning that sodium and chloride concentrations in permeate are only slightly lower than those in raw seawater [39]. Scaling of the pipe lines and wells, and the production of hydrogen sulfide gas by sulfate reducing micro-organisms [39] in the sub-surface oil wells is sufficiently reduced by the strong reduction of sulfate concentrations in well-injection brine. The retentate, which has increased contaminant concentrations, is discharged back into the sea. Often pre-treatment (filtration and de-aeration), a Christmas tree design and spiral wound thin film composite FilmTec ${ }^{\mathrm{TM}}$ SR90 (originally FilmTec ${ }^{\mathrm{TM}}$ NF40 [39]) membranes are being used for this application [41]. Operating pressures range between 20 and 30 bar [40]. A 
lot of these Sulphate Removal systems, originally developed in 1987 by DOW and Marathon, have been implemented by Aker Solutions [40], as shown in Table 2.

More nanofiltration applications for preparation of injection water can be found in [39]. Several alternative nanofiltration membranes are available for this application, as will be discussed in the next paragraph discussing the use of nanofiltration as pre-treatment for seawater desalination using reverse osmosis. One of the membrane suppliers claiming better performance (permeance and sulfate retention) of its membranes (NFW, NFX and NFS) is Synder Filtration [44, 45].

Table 2: Examples of implemented off-shore Sulphate Removal Systems [40, 42, 43]

\begin{tabular}{l|c|c|c}
\hline Location & $\begin{array}{c}\text { Capacity } \\
\left(\mathbf{m}^{\mathbf{3}} \mathbf{h}\right)\end{array}$ & End-user & $\begin{array}{c}\text { Completion } \\
\text { year }\end{array}$ \\
\hline OSX 3 & 1790 & Petrobas & 2012 \\
P62 & 2520 & Petrobas & 2011 \\
P58 & 670 & Modec & 2009 \\
Cidade de Angra dos Reis MV22 & 1540 & Modec & 2009 \\
Kwame Nkrumah MV21 & 205 & Modec & 2009 \\
Cidade de Santos MV20 & 915 & Modec & 2008 \\
Cidade de Niteroi MV18 & 795 & Modec & 2006 \\
Cidade do Rio de Janerio MV14 & 1630 & Petrobras & 2006 \\
P54 - Roncador & 1460 & Petrobras & 2003 \\
P50 -Albacora Leste & 895 & BWO & 2001 \\
Ceiba & \multicolumn{2}{|}{} \\
\hline
\end{tabular}

\subsection{Pre-treatment for reverse osmosis seawater desalination}

Nanofiltration is used as pre-treatment for seawater desalination by reverse osmosis as well. At least one industrial application has been reported, Umm Lujj in Saudi Arabia [46]. In September 2000 Desal DK (GE/Osmonics) modules were installed in 27 parallel housings containing 6 eight inch modules each, resulting in approximately $5300 \mathrm{~m}^{2}$ effective membrane surface area. The feed is supplied at a flow of $360 \mathrm{~m}^{3} \cdot \mathrm{h}^{-1}$, and $65 \%$ permeate recovery and a permeate flux of approximately $40-45 \mathrm{~L} . \mathrm{m}^{-2} \cdot \mathrm{h}^{-1}$ were obtained at 25 bar operating pressure. Sulfate and divalent cation concentrations in the feed to the reverse osmosis unit were drastically reduced as a consequence of the 
obtained high retentions of more than $99 \%$ for sulfate, $98 \%$ for magnesium, $92 \%$ for calcium and $44 \%$ for bicarbonate. Chloride retention was between $45-50 \%$, dropping chloride concentration from $2.16 \%$ in the seawater to $1.64 \%$ in the NF permeate. The implementation of the nanofiltration unit resulted in $30 \%$ higher overall recovery from the desalination system, next to the 11 bar lower operating pressure that could be used in the RO unit (reducing from 65 to 54 bar) which leads to lower overall energy consumption [46]. As additional benefit the production of salts such as sodium chloride salt from the NF/RO retentate is mentioned. The initial concentration for the suggested solar salt production is around $5 \% \mathrm{w} \mathrm{NaCl}$ in brine at $98 \%$ purity in this case. The application of nanofiltration as reverse osmosis desalination pre-treatment step is not always economically viable, but especially suitable when the reverse osmosis membranes experience strong fouling [46]. Alternative nanofiltration membranes from Dow Chemical (NF-200, NF-270 and NF-90), Hydranautics (ESNA 1-LF2), Alfa Laval Membranes (NF99HF) and Koch Membrane Systems (K-SR2) were studies by Llenas et al. [47]. Apart from ESNA 1-LF2 all membranes showed sulfate retentions in excess of $95 \%$ and chloride retentions between $10-40 \%$, depending on the membrane selected, for processing a synthetic solution mimicking seawater. For most membranes magnesium and calcium retentions were in the range of $80-90 \%$ and $60-70 \%$, respectively. NF-90 and ESNA 1-LF2 membranes had considerably higher and lower retentions, respectively. Furthermore, strong differences in bicarbonate retentions were found for the different membranes evaluated, again with NF-90 at the high and ESNA 1LF2 at the low side of the spectrum. High bicarbonate retention is desired to further reduce scaling of the $\mathrm{RO}$ membranes. On the basis of observed retention and permeance characteristics NF-270, NF99HF and K-SR2 were mentioned to be the most suitable membranes for the application [47]. Pontie et al. [48] used a synthetic solution containing $35 \mathrm{~g} . \mathrm{L}^{-1} \mathrm{NaCl}$ and seawater from Le Croisic (Loire-Atlantique, west of France) to evaluate the use of nanofiltration as pre-treatment of desalination via RO. They reported that NF-200 (Dow FilmTec) is superior over NF (Dow FilmTec), MPS-34 and MPS-44 (both Koch Membrane Systems), especially since this membrane shows higher permeance than especially the Koch membranes for processing of the synthetic solution. Furthermore, this membrane also showed higher $\mathrm{NaCl}$ retention $(60 \%$ at 30 bar operating pressure) than the others, which is favorable for the subsequent $\mathrm{RO}$ treatment as this will lead to reduced osmotic pressure in the RO unit. Sulfate retentions were not presented in the study. It should be noted, that Desal DK was not evaluated in these studies. 


\subsection{Nanofiltration of reverse osmosis concentrates from seawater desalination processes}

As mentioned earlier, reverse osmosis is extensively used for the production of water in areas where potable water is scarce, such as in Saudi Arabia, but in many other countries as well. Either brackish ground water or seawater is used as feed. Often the RO retentates (concentrates) from sea water desalination, either pre-treated with nanofiltration or by other pre-filtration steps, are discharged back into the sea. However, the discharge of these retentates can negatively affect marine environment and has become more and more restricted. Therefore alternative usage for this stream is being sought. Perez-Gonzales et al. $[49,50]$ have evaluated the production of hydrochloric acid and sodium hydroxide from this RO retentate via bi-polar membrane technology. This seems to be feasible provided that (especially) sulfate is removed from the RO retentate. Typical sodium chloride and sulfate concentrations for these types of streams from seawater desalination plants in Spain are mentioned to be $40-60 \mathrm{~g} \cdot \mathrm{L}^{-1} \mathrm{NaCl}$ and $5000-7500 \mathrm{mg} \cdot \mathrm{L}^{-1}$ sulfate. Due to the use of RO for concentrating the seawater, these retentates obviously contain higher sodium chloride and sulfate concentrations than seawater. Using a NF-270 (FilmTec) membrane and processing a synthetic solution consisting of $70 \mathrm{~g} \cdot \mathrm{L}^{-1} \mathrm{NaCl}$ and $8000 \mathrm{mg} \cdot \mathrm{L}^{-1}$ sulfate, retentions for chloride and sulfate in the range of $0-10 \%$ and $75-85 \%$, respectively were reported, depending on membrane flux [51].

\subsection{Nanofiltration in Chlor-Alkali production}

Nanofiltration also provides a solution for the avoidance of sulfate build-up in the brine recycle to Chlor/Alkali producing (membrane) electrolysis cells. In this application $\mathrm{NaCl}$ salt is dissolved in the depleted recycle brine from the Chlor/Alkali cell. Although high purity vacuum $\mathrm{NaCl}$ salt, which contains only minor amounts of impurities such as sulfate and divalent cat-ions, is often used for $\mathrm{Cl}_{2}$ and caustic production, removal of these impurities is needed to avoid scaling on and plugging of the cation exchange membranes. Scaling and plugging leads to higher membrane resistance and therefore higher energy consumption, which is a major cost factor in the Chlor/Alkali production. Multi-valent cations are usually removed from the feed stream by ion exchange. Sulfate removal can be done by purging part of the recycle brine, leading to production of considerable brine waste streams and loss of valuable $\mathrm{NaCl}$ resources, or by treating part of the recycle brine with a barium source, leading to $\mathrm{BaSO}_{4}$ precipitation and 
removal. However, purchase costs and disposal costs, next to environmental concerns prohibit this latter option more and more [46]. The use of nanofiltration to treat part of the recycle stream (see Fig. 4), thereby producing a retentate high in sodium sulfate which can be discharged, and a permeate low in sulfate which can be returned to the recycle brine, can reduce the discharge of valuable $\mathrm{NaCl}$ containing brine and can avoid the use and discharge of environmentally unfriendly barium [51].

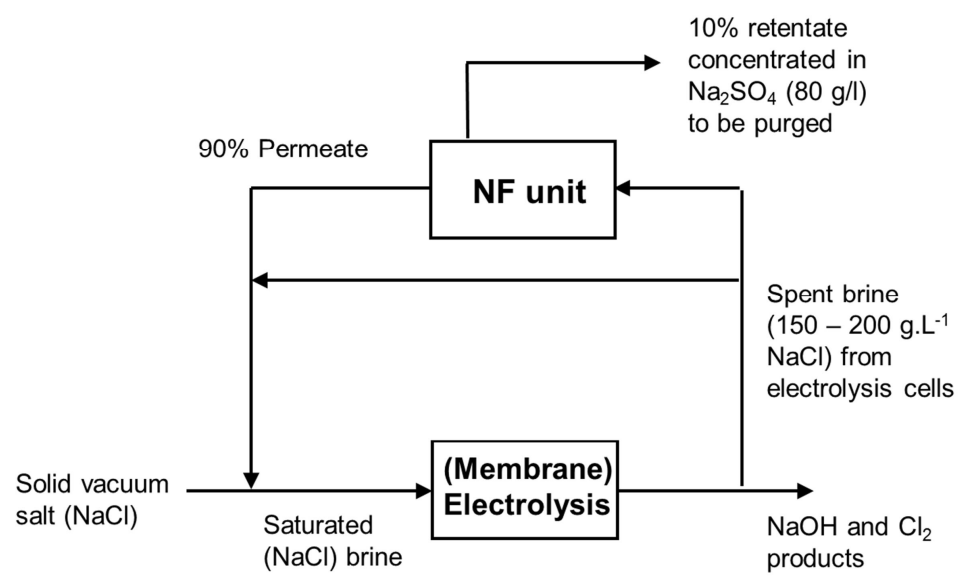

Figure 4: Schematic representation of the use of nanofiltration in Chlor/Alkali production

The application has been developed by Chemetics and has been protected by patents (e.g. [52]). The commercialization of this application started with a first industrial unit at the Occidental Chemical Chlor/Alkali production plant in Delaware in 1997 [53]. The application and its development have been described in detail by Barr [54], Maycock et al. [53] and Bessarabov and Twardowski [51]. Since that time more than 70 plants have been installed world-wide [55]. One of these plants is Solvic Chlor-alkali plant in Jemeppe (Belgium) where the sulfate concentration is increased in three concentration steps to $70 \mathrm{~g} \cdot \mathrm{L}^{-1}$ [55]. The unit is operated at 40 bar pressure [55]. Desal 5DK (GE/Osmonics) is often used as membrane in this application [46] with claimed membrane life time in excess of 18 months [55]. Other membrane types can be used for this application as well. Sulfate retention for Desal DK is reported to be in excess of $95 \%$, whereas sodium chloride retention is reported to be close to zero or even slightly negative $[46,56,57]$. These observations are confirmed in lab-scale experiments in a 
DSS labstak unit (Bargeman, Guerra-Miguez and Westerink, unpublished results). In these experiments it is shown that for other nanofiltration membranes similar retention results could be obtained for processing a synthetic solution containing $175 \mathrm{~g} . \mathrm{L}^{-1} \mathrm{NaCl}$ and sodium sulfate concentrations ranging from $5-60 \mathrm{~g} \cdot \mathrm{L}^{-1}$ at pressures between 5 and 25 bar (see Fig. 5). When sulfate concentrations in the retentate increase, chloride retentions tend to decrease slightly for these membranes. Furthermore, at constant sulfate concentrations in the feed (leading to similar differences in sulfate concentrations between retentate and permeate) a lower flux leads to slightly lower chloride retention. Desal 5DK did show the highest sulfate retentions (up to 99\%) of the membranes evaluated, with NTR-750, Desal $5 \mathrm{HL}$ and NF-270 showing measured sulfate retentions in excess of $95 \%, 90 \%$ and $85 \%$, respectively. The membrane fluxes of these membranes differed by only $20 \%$.

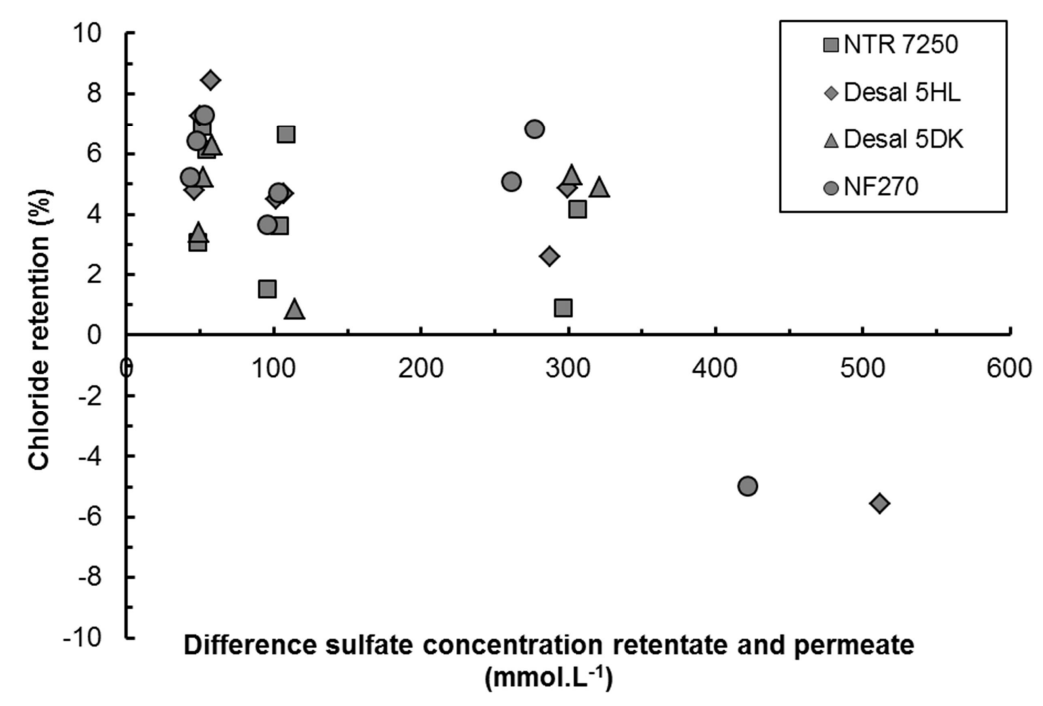

Figure 5: Chloride retention as function of the difference in sulfate concentration between retentate and permeate for lab-scale test with membrane fluxes in excess of $10 \mathrm{~L} \cdot \mathrm{m}^{-2} \cdot \mathrm{h}^{-1}$ processing synthetic brine solutions containing 175 g. $\mathrm{L}^{-1} \mathrm{NaCl}$ and sodium sulfate concentrations ranging from $5-60 \mathrm{~g} \cdot \mathrm{L}^{-1}$.

\subsection{Nanofiltration in solid sodium chloride salt production}

One of the incentives of using nanofiltration in the production of crystalline sodium chloride vacuum salt (see Fig. 6 for a schematic representation of a salt plant) is the 
removal of impurities from the salt brine obtained via solution mining. Obviously, the crystallization process is an important purification step in the production of the salt, but normally other measures to produce sufficiently pure vacuum salt have to be taken as well, especially when these salt crystals will be used for the production of chlorine or its derivatives. Impurities that need to be removed from the produced salt brine are multivalent cations such as magnesium, calcium and strontium and divalent anions such as sulfate and carbonate [58]. In the current process, in most cases sulfate and carbonate are added to the brine in the raw brine purification step of the process as well. This is done to remove the multivalent cations by solidifying salt impurities, such as calcium sulfate. Additionally caustic is often added to the brine to remove magnesium ions as magnesium hydroxide particles. These solidified impurities can subsequently be removed from the saturated brine by settling. The purified brine or feed brine thus obtained is sent to the evaporators where the brine is further concentrated and sodium chloride is crystallized. This process is often continued until the brine becomes saturated in sodium sulfate as well. Since there usually is an excess of sulfate in the process, purging part of the brine or crystallizing sodium sulfate and removing it from the process is needed.

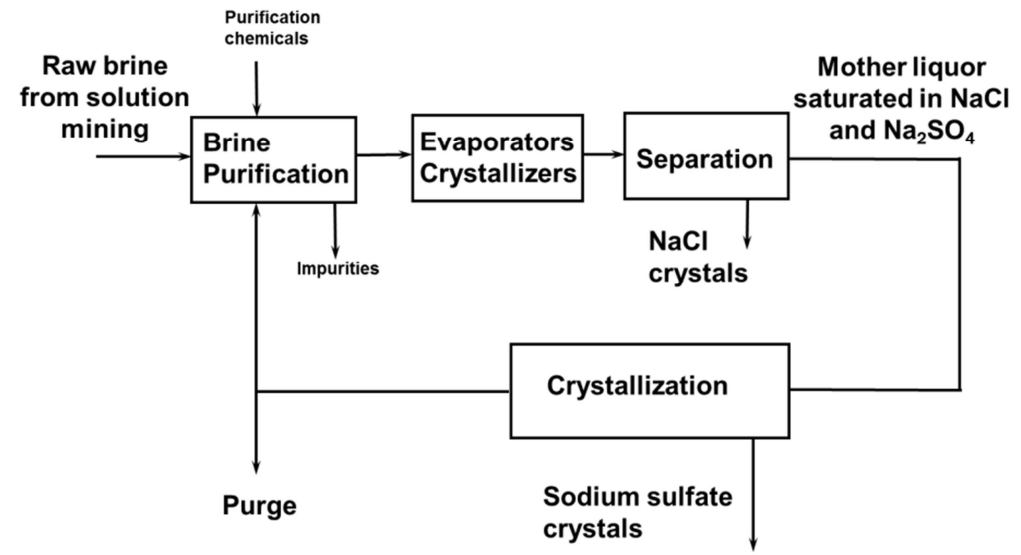

Figure 6: Schematic representation of a vacuum salt plant.

Nanofiltration technology can be implemented at different parts of the salt plant when efficient removal of sulfate or divalent cations from the process is needed. Removal of sulfate from practically saturated raw brine at high sulfate retentions $(>95 \%)$ can be obtained by different nanofiltration membranes [59]. 
Nanofiltration can thus (partly) replace the brine purification step in the salt production plant. To achieve this it is essential that not only sulfate concentration in the raw brine is decreased, but calcium, strontium and magnesium concentrations as well. The removal of these ions by nanofiltration is improved by the presence of minor amounts of a socalled positive retention enhancing compound [59]. Calcium retentions in raw brine can be increased substantially, as can be seen by comparing calcium retentions for processing raw brine without any addition of positive retention enhancing components and raw brine to which 600 ppm Drewsperse 747A has been added, as illustrated in Figure 7 for Desal DK. For this membrane strontium and magnesium retentions in excess of $90 \%$ were obtained, while sulfate retention was in excess of $96 \%$ [59] for raw brine containing Drewsperse 747A. For NF-270 slightly lower divalent cation retentions, but slightly higher sulfate retention was obtained.

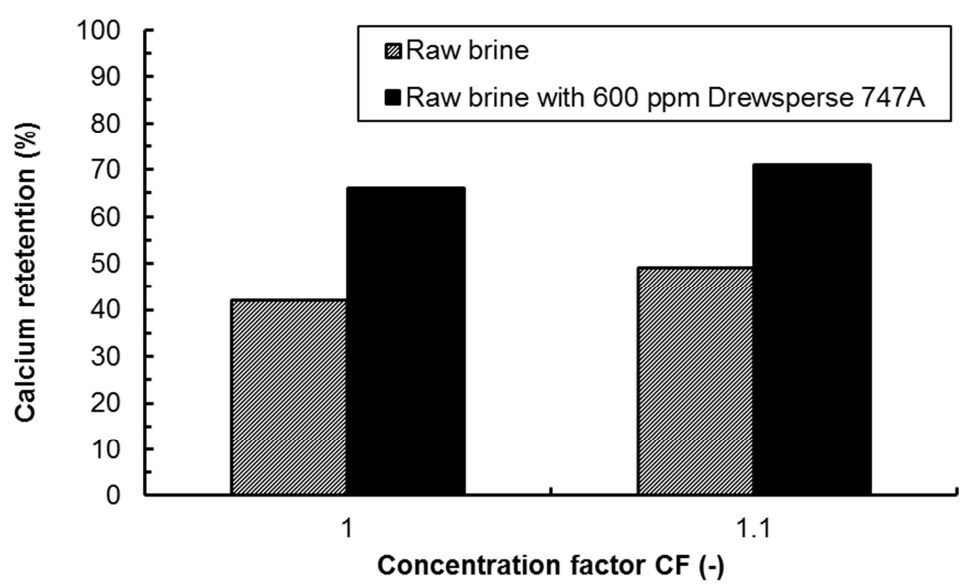

Figure 7: The effect of addition of Drewsperse 747A on calcium retention as function of concentration factor for Desal 5DK during lab-scale processing of raw brine at room temperature and 31 bar operating pressure [59].

Samhaber at al. evaluated the potential of nanofiltration for the concentration of sodium sulfate in mother liquor from the salt crystallization process in pilot trials at Austrian Salt Works in Ebensee [60]. The intention of this application is to concentrate and recycle the sulfate to the brine purification, where it is used as purification chemical for the removal of calcium and to produce sodium chloride salt crystals from the purified permeate lean in sulfate. In these trials the mother liquor was diluted by $10-15 \%$ water 
or raw brine, prior to feeding it to the nanofiltration membranes to decrease the sulfate concentration and to avoid crystallization of sodium sulfate in the nanofiltration membranes [60]. The $\mathrm{pH}$ of the mother liquor was kept below 10 , the temperature was reduced to $30^{\circ} \mathrm{C}$ and the operating pressure was set at 30 bar. Obtained sulfate retentions were between 98 - 99\%, while negative chloride (ranging from $0 \%$ to $-5 \%$ ) and bromide (ranging from $-10 \%$ to $-15 \%$ ) retentions were reported. Based on the performance a membrane lifetime in excess of 18 months was predicted. The membrane that was used for these trials was Desal 5DK [61, 62]. In their process excess sulfate was removed from the plant via a purge waste stream, super-saturation was avoided and sodium sulfate crystallization was not used.

A disadvantage of the nanofiltration option proposed by Samhaber et al. is the need for dilution of the mother liquor. Furthermore, the absence of sodium sulfate crystallization for removal of excess of sulfate in the plant leads to relatively high purge streams. The presence of sodium sulfate crystallization consequently has clear benefits, but is usually quite energy intensive as well. The high energy consuming sodium sulfate removal crystallization process fed with salt crystallization mother liquor (saturated in both sodium sulfate and sodium chloride) can be replaced by a nanofiltration step to create a retentate supersaturated in sodium sulfate, which is subsequently sent to a crystallizer to produce anhydrous sodium sulfate crystals. Crystallization of the sodium sulfate in the nanofiltration membrane modules is avoided by the presence of small amounts of crystal growth inhibitor [63]. In this process a permeate lean in sodium sulfate and practically saturated in sodium chloride is produced.

Nanofiltration is used in the salt production plant of AkzoNobel Industrial Chemicals in Hengelo (the Netherlands) since 2012, removing sulfate from brine [64]. The application of nanofiltration installed in a partnership with Chemetics (a Jacobs Company), leads to $1.5-2 \%$ efficiency increase (less salt loss) and is reported to save 2.75 million $\mathrm{m}^{3}$ of natural gas per year.

\section{Scope and outline}

In most scientific studies on nanofiltration either the development of new membrane materials or the characterization of membranes is reported. In the latter case most studies use single solute salt or sugar solutions and low concentrations relative to 
solution concentrations used in industrial applications. Several of these studies try to predict retention performance of nanofiltration membranes for salt solutions containing two different salts, on the basis of these characterization experiments and derived model parameters (e.g. [31]), often with limited success. Furthermore, only limited knowledge is available from open literature on the effect of salt ions on retention of neutral solutes such as glucose and vice versa. A better insight in this phenomenon is needed, since several nanofiltration applications treat solutions containing a combination of salts and neutral components such as sugars. In Chapter 2 of this thesis the results of the effect of different monovalent and divalent salts on the retention of glucose are discussed and explained for several commercially available nanofiltration membranes. In Chapter 3 the results of the effects of much high sodium chloride and glucose concentrations in the solution (300 g. $\mathrm{L}^{-1}$ and $80 \mathrm{~g} \cdot \mathrm{L}^{-1}$, respectively) on salt and glucose retention are presented and discussed to extend the concentration window. In the work described in this chapter several other commercially available membranes have been evaluated as well.

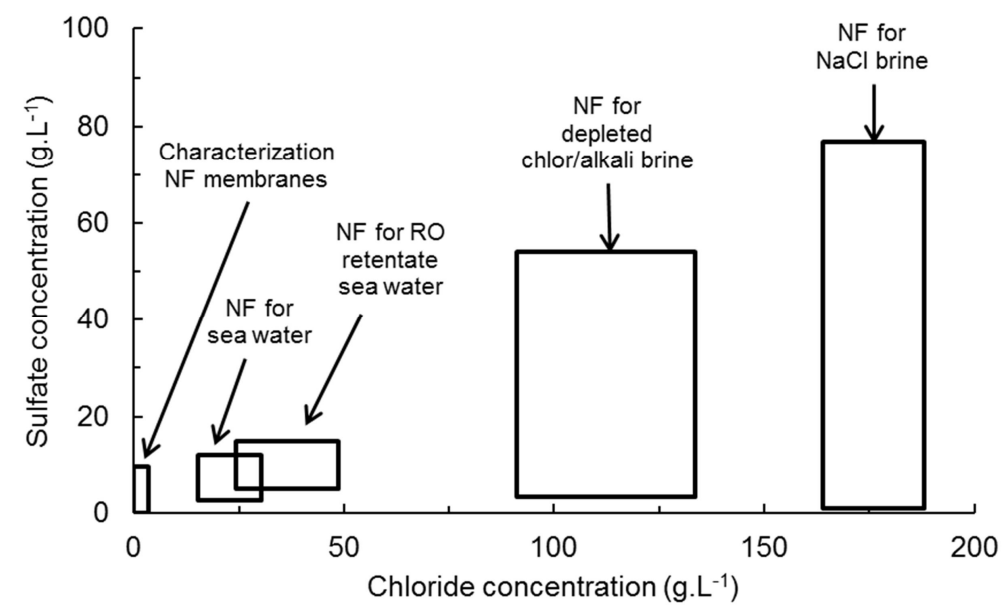

Figure 8: Chloride and sulfate concentrations of solutions used in nanofiltration membrane characterization, and nanofiltration of sea water, RO retentate of sea water, depleted brine from chlor/alkali production and $\mathrm{NaCl}$ salt production.

Furthermore, there has been limited attention in open literature for nanofiltration membrane performance for more concentrated salt solutions, despite the fact that a 
substantial amount of (potential) applications deals with these types of solutions (see Fig. 8) as shown in the previous sections.

Therefore, the other chapters deal with creating a better understanding of nanofiltration of salt solutions containing mainly sodium chloride and sodium sulfate at practically relevant concentrations. Chapter 4 discusses nanofiltration of solutions saturated in both sodium sulfate and sodium chloride using commercially available membranes, thus creating a concentrate super-saturated in sodium sulfate and saturated in sodium chloride, and a permeate practically saturated in sodium chloride and lean in sodium sulfate. A relation between chloride retention and the sulfate concentration difference between retentate and concentrate is presented.

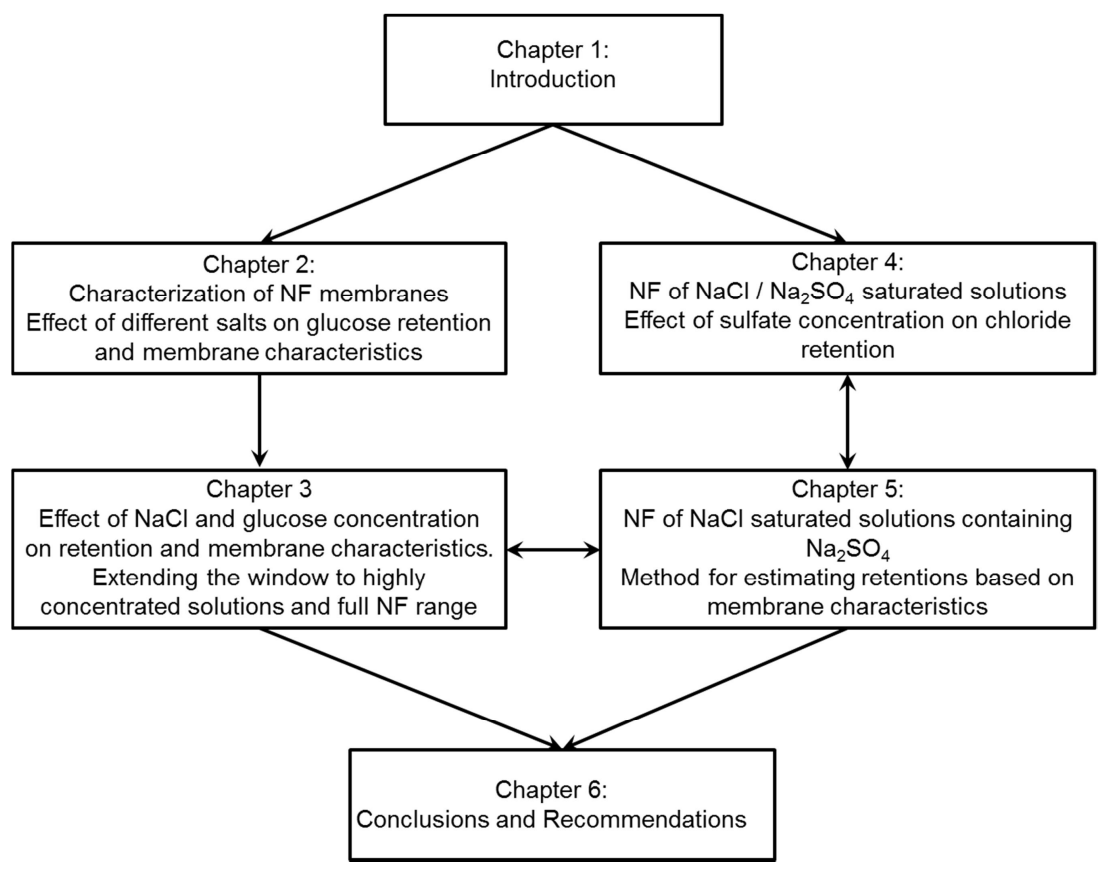

Figure 9: Structure of the dissertation and relationship between the different chapters.

In Chapter $\mathbf{5}$ nanofiltration of a solution saturated in sodium chloride and lean in sodium sulfate is presented and discussed. In this chapter it will be shown that the same retention relation for chloride with the difference in sulfate concentration between 
retentate and permeate will be obtained, irrespective of the nanofiltration membrane type used, and that this can be explained on the basis of thermodynamic considerations.

In Chapter 6, the conclusions and recommendations will be presented. The relationship between the different chapters is furthermore outlined in Fig. 9.

\section{References}

[1] A.A. Kiss, S.J. Flores Landaeta, C.A. Infante Ferreira, Towards energy efficient distillation technologies - making the right choice, Energy 47 (2012) 531-542.

[2] P.H. Fergusson, Developments in the evaporation and drying of dairy products, International Journal of Dairy Technology 42 (1989) 94-101.

[3] D.H. Kim, A review of desalting process techniques and economic analysis of the recovery of salts from retentates, Desalination 270 (2011) 1-8.

[4] O.Yildirim, A.A. Kiss, E.Y. Kenig, Dividing wall columns in chemical process industry: a review on current activities, Sep. Purif. Technol., 80 (2011) 403417.

[5] S.J. Flores Landaeta, A.A. Kiss, Selection of heat pump technologies for energy efficient distillation, Computer Aided Chemical Engineering 30 (2012) 267-271.

[6] A.A. Kiss, S.J. Flores Landaeta, C.A. Infante Ferreira, Mastering heat pumps selection for energy efficient distillation, Chem. Eng. Trans. 29 (2012) 397-402.

[7] M.T.G. Jongmans, A. Londono, S. Babu Mamilla, H. Pragt, K. Aaldering, G. Bargeman, M. Nieuwhof, A. ten Kate, P. Verwer, T. Kiss, C. van Strien, B. Schuur, A.B. de Haan, Extractant screening for the separation of dichloroacetic acid from monochloroacetic acid by extractive distillation, Sep. Purif. Technol. 98 (2012) 206-215.

[8] A.A. Kiss, Distillation | Extractive Distillation, In Reference Module in Chemistry, Molecular Sciences and Chemical Engineering (2013) current as of 22 January 2015, http://dx.doi.org/10.1016/B978-0-12-409547-2.05949-7.

[9] A. Gorak and E. Sorensen (Eds.), Distillation: Fundamentals and Principles 1st ed. (2014), Academic Press - Elsevier, Amsterdam, The Netherlands.

[10] H. Strathmann, L. Giorno and E. Drioli, Introduction to membrane science and technology Vol. 544 (2011), Wiley-VCH Verlag \& Company. 
[11] B. Van der Bruggen and C. Vandecasteele, Distillation vs. membrane filtration: overview of process evaluations in seawater desalination Desalination 143 (2002) 207-218.

[12] R.W. Baker, Membrane technology and applications, $3^{\text {rd }}$ edition (2012), John Wiley \& Sons Ltd, Chichester, UK.

[13] G. Bargeman, M. Timmer, C. van der Horst, Nanofiltration in the food industry, Chapter 12 in Nanofiltration - Principles and Applications $1^{\text {st }}$ edition, Eds. A.I. Schaefer, A.G. Fane and T. D. Waite, (2005), 305-328, Elsevier Advanced Technologies, Oxford, UK.

[14] J.M.K. Timmer, H.C. van der Horst, Whey processing and separation technology: State-of-the-art and new developments, WHEY Proceedings of the second International Whey Conference, held in Chicago, USA, 27-29 October 1997, IDF Special Issue 9804 (1998), International Dairy Federation, Diamant Building 80, Boulevard Auguste Reyers, 1030 Brussels, Belgium, 40-65.

[15] F.P. Cuperus and K. Ebert, Non-aqueous applications of NF, Chapter 21 in Nanofiltration - Principles and Applications $1^{\text {st }}$ edition, Eds. A.I. Schaefer, A.G. Fane and T. D. Waite, (2005), 305-328, Elsevier Advanced Technologies, Oxford, UK.

[16] M. Mulder, Energy requirements in membrane separation processes, chapter 4 in J.G. Crespo and K.W. Böddeker (Eds.), Membrane processes in separation and purification, 272 (1994) Springer Science \& Business Media.

[17] C.M. Tram and A.Y. Tremblay, Membrane pore characterisation-comparison between single and multicomponent solute probe techniques, J. Membr. Sci., 57 (1991) 271-287.

[18] P. Pradanos, J.I. Arribas and A. Hemandez, Hydraulic permeability, mass transfer, and retention of PEGs in cross-flow ultrafiltration through symmetric microporous membrane, Sep. Sci. Tech, 27 (1992) 2121-2142.

[19] S. Platt, M. Mauramo, S. Butylina and M. Nystrom, Retention of pegs in crossflow ultrafiltration through membranes, Desalination 149 (2002) 417-422.

[20] CHARMME Network, Harmonization of characterization methodologies for porous membranes, EC Contract SMT4-CT 98-7518, 2001.

[21] S. Zeidler, P. Puhlfürß, U. Kätzel, I. Voigt, Preparation and characterization of new low MWCO ceramic nanofiltration membranes for organic solvents, J. Membr. Sci. 470 (2014) 421-430. 
[22] A.F.M. Pinheiro, D. Hoogendoorn, A.I. Nijmeijer and L. Winnubst, Development of a PDMS-grafted alumina membrane and its evaluation as solvent resistant nanofiltration membrane, J. Membr. Sci. 463 (2014) 24-32.

[23] M. Dalwani, G. Bargeman, S. Hosseiny, M. Boerrigter, M. Wessling, N. Benes, Sulfonated poly (ether ether ketone) based composite membranes for nanofiltration of acidic and alkaline media, J. Membr. Sci. 381 (2011) 81-89.

[24] M. Dalwani, N.E. Benes, G. Bargeman, D. Stamatialis, M. Wessling, Effect of $\mathrm{pH}$ on the performance of polyamide/polyacrylonitrile based thin film composite membranes, J. Membr. Sci. 372 (2011) 228-238.

[25] K.P. Lee, J. Zheng, G. Bargeman, A.J.B. Kemperman, N.E. Benes, pH stable thin film composite polyamine nanofiltration membranes by interfacial polymerization, J. Membr. Sci. 478 (2015) 75-84.

[26] M. Dalwani, J. Zheng, M. Hempenius, M.J.T. Raaijmakers, C.M. Doherty, A.J. Hill, M. Wessling and N.E. Benes, Ultra-thin hybrid polyhedral silsesquioxanepolyamide films with potentially unlimited $2 \mathrm{D}$ dimensions. Journal of Materials Chemistry 22 (2012) 14835-14838.

[27] I.F.J. Vankelecom, K. De Smet, L.E.M. Gevers, P.A. Jacobs, Nanofiltration membrane materials and preparation, Chapter 3 in Nanofiltration - Principles and Applications $1^{\text {st }}$ edition, Eds. A.I. Schaefer, A.G. Fane and T. D. Waite, (2005), 305-328, Elsevier Advanced Technologies, Oxford, UK.

[28] M.H.V. Mulder, E.M. van Voorthuizen, J.M.M. Peeters, Membrane Characterization, Chapter 5 in Nanofiltration - Principles and Applications $1^{\text {st }}$ edition, Eds. A.I. Schaefer, A.G. Fane and T. D. Waite, (2005), 305-328, Elsevier Advanced Technologies, Oxford, UK.

[29] C. Bellona, J.E. Drewes,P. Xu and G. Amy, Factors affecting the rejection of organic solutes during NF/RO treatment-a literature review, Water Research 38 (2004) 2795-2809.

[30] W.R. Bowen and J.S. Welfoot, Modelling the performance of nanofiltration membranes, Chapter 6 in Nanofiltration - Principles and Applications $1^{\text {st }}$ edition, Eds. A.I. Schaefer, A.G. Fane and T. D. Waite, (2005), 305-328, Elsevier Advanced Technologies, Oxford, UK.

[31] J. Straatsma, G. Bargeman, H.C. van der Horst, J.A. Wesselingh, Can nanofiltration be fully predicted by a model?, J. Membr. Sci. 198 (2002) 273. 
[32] W.R. Bowen, A.W. Mohammad, N. Hilal, Characterization of nanofiltration membranes for predictive purposes- use of salts, uncharged solutes and atomic force microscopy, J. Membr. Sci. 126 (1997) 91-105.

[33] A.I. Schaefer, A.G. Fane and T. D. Waite (Eds.), (2005), Nanofiltration Principles and Applications $1^{\text {st }}$ edition, 305-328, Elsevier Advanced Technologies, Oxford, UK.

[34] E. Wittmann and T. Thorsen, Water treatment, Chapter 10 in Nanofiltration Principles and Applications $1^{\text {st }}$ edition, Eds. A.I. Schaefer, A.G. Fane and T. D. Waite, (2005), 305-328, Elsevier Advanced Technologies, Oxford, UK.

[35] T. Fane, P. Macintosh and G. Leslie, Water reclamation, remediation and cleaner production with nanofiltration, Chapter 11 in Nanofiltration - Principles and Applications $1^{\text {st }}$ edition, Eds. A.I. Schaefer, A.G. Fane and T. D. Waite, (2005), 305-328, Elsevier Advanced Technologies, Oxford, UK.

[36] M. Kyburz and G.W. Meindersma, Nanofiltration in the chemical processing industry, Chapter 13 in Nanofiltration - Principles and Applications $1^{\text {st }}$ edition, Eds. A.I. Schaefer, A.G. Fane and T. D. Waite, (2005), 305-328, Elsevier Advanced Technologies, Oxford, UK.

[37] C. Tang and V. Chen, Nanofiltration of textile dye effluent, Chapter 15 in Nanofiltration - Principles and Applications $1^{\text {st }}$ edition, Eds. A.I. Schaefer, A.G. Fane and T. D. Waite, (2005), 305-328, Elsevier Advanced Technologies, Oxford, UK.

[38] M. Nyström, J.M.K. Nuortila-Jokinen and M. Mänttäri, Nanofiltration in the pulp and paper industry, Chapter 14 in Nanofiltration - Principles and Applications $1^{\text {st }}$ edition, Eds. A.I. Schaefer, A.G. Fane and T. D. Waite, (2005), 305-328, Elsevier Advanced Technologies, Oxford, UK.

[39] R.A. Davis and J.E. McElhiney, The advancement of sulfate removal from seawater in offshore waterflood operations, Corrosion 2002, paper 02314, http://msdssearch.dow.com/PublishedLiteratureDOWCOM/dh_0044/0901b803 80044462.pdf?filepath=liquidseps/pdfs/noreg/016-

00045.pdf\&fromPage $=$ GetDoc

[40] http://www.akersolutions.com/Global/ProcessSystems/SRU\%20final.pdf [41]

http://www.akersolutions.com/Documents/Drilling\%20Technologies/Process $\%$ 20Systems/Processing_solution_brochure.pdf 
[42] Kvaerner Process Systems 2000, rev. 02, Water Treatment - Injection Water, Seawater Sulphate Reduction Systems, Seawatersulfatereductionsystem. PDF from www.akersolutions.com.AkerSolutions Seawater Sulphate Reduction Systems, November 2009, from www.akersolutions.com.

[43]

http://www.akersolutions.com/Documents/Process\%20Systems/Refer ence $\% 20$ List $\% 20-\% 20$ Water\%20injection.pdf

[44] http://www.synderfiltration.com/wp-content/uploads/2011/12/Synder-SeawaterSulfate-Removal.pdf

[45] http://synderfiltration.com/synder-introduces-new-nfs-membrane-for-sulfateremoval-applications/

[46] P. Eriksson, M. Kyburz and W. Pergrande, Nanofiltration membrane characteristics and evaluation for sea water processing applications, Desalination 184 (2005) 281-294.

[47] L. Llenas, X. Martinez-Llado, A. Yaroshchuk, M. Rovira, J. de Pablo, Nanofiltration as pretreatment for scale prevention in seawater reverse osmosis desalination, Desalination and Water Treatment 36 (2011) 310-318.

[48] M. Pontié, J.S. Derauw, S. Plantier , L. Edouard \& L. Bailly, Seawater desalination: nanofiltration-a substitute for reverse osmosis?, Desalination and Water Treatment 51 (2013) 485-494.

[49] A. Pérez-González, R. Ibáñez, P. Gómez, A. Urtiaga, I. Ortiz, Integration of nanofiltration for the sustainable management of reverse osmosis brines Chem. Eng. Trans. 39 (2014) 85-90.

[50] A. Pérez-González, R. Ibáñez, P. Gómez, A.M. Urtiaga, I. Ortiz, J.A. Irabien, Nanofiltration separation of polyvalent and monovalent anions in desalination brines, J. Membr. Sci. 473 (2015) 16-27.

[51] D. Bessarabov and Z. Twardowski, Industrial application of nanofiltration new perspectives, Membrane Technology 9 (2002) 6-9.

[52] Z. Twardowski, Nanofiltration of concentrated aqueous salt solutions, EP 0821 615 B2

[53] K. Maycock, C. Kotzo, F. Muret, Z. Twardowski, J. Ulan, Commercialisation of Kwaerner Chemetics' Sulphate Removal System, Chapter 11 in J. Moorehouse (eds.), Modern Chlor Alkali Technology, vol. 8, 2008, John Wiley \& Sons. 
[54] A. Barr, Sulphate Removal by Nanofiltration, Filtration \& separation 8 (2001) 18-20.

[55] T. Brinkmann, G. Giner Santonja, F. Schorcht, S. Roudier, L. Delgado Sancho, Best Available Techniques (BAT) reference document for the production of Chlor-alkali, EU JRC Science and policy report (2014), ISBN 978-92-7940945-5 (PDF),

http://www.prtr-es.es/Data/images/BREF_Chlor_alkali_2014.pdf

[56] F.N. Karelin, A.A. Askerniya, M.L. Gril, O.F. Parilova, Salt concentration and recovery from aqueous solution using barometric membrane processes, Preprints $7^{\text {th }}$ International Symposium on Synthetic Membranes in Science and Industry, Tübingen (Fed. Rep. of Germany), August 29 - September 1, 1994, 308-311.

[57] F.N. Karelin, A.A. Askerniya, M.L. Gril, O.F. Parilova, Salt concentration and recovery from aqueous solutions using pressure-driven membrane processes Desalination 104 (1996) 69-74

[58] R.M. Geertman, Sodium chloride: Crystallization, Reference Module in Chemistry, Molecular Sciences and Chemical Engineering (2000) 4127-4134.

[59] G. Bargeman, R.L.M. Demmer, A. ten Kate, B. Kuzmanovic, C.E.J. van Lare, M.J.J. Mayer, M.A.I. Schutyser, J.B. Westerink, Process to prepare salt, EP 1 858806 B1, CN101119930 B, US 8038883 B2 (WO06/087302 A1).

[60] W.M. Samhaber, K. Krenn, T. Raab, H. Schwaiger, Field test results of a NF application for separating almost saturated brine solutions of the vacuum salt production ECCE Nurnberg June 2001, www.ivt.unilinz.ac.at/Forschung/Publikationen/pdf/ecce1.pdf.

[61] W. Samhaber, Die Industrielle Anwendung der Nanofiltration - Potentiale, Erfahrungen und Grenzen, Chemie Ingenieur Technik 77 (2005) 566-572.

[62] W.M. Samhaber and H. Schwaiger, The application of nanofiltration in the salt industry, 14th International Congress of Chem. and Proc. Eng. (CHISA 2000), Prague, August 2000.

[63] G. Bargeman, R.L.M. Demmer, B. Kuzmanovic, C.E.J. van Lare, M.J.J. Mayer, M.A.I. Schutyser, J.B. Westerink, Method for crystallizing soluble salts of divalent anions from brine, US 7858058 B2, CN 101044091 B and EP 1807 349 B1 (WO06/045718 A1).

[64] http://www.akzonobel.com/ic/system/images/AkzoNobel_Nano_GBmed_tcm18-75380.pdf. 


\section{Chapter 2}

\section{Nanofiltration of multi-component feeds. Interactions between neutral and charged components and their effect on retention}

This chapter has been published as:

G. Bargeman, J.M. Vollenbroek, J. Straatsma, C.G.P.H. Schroën, R.M. Boom, Nanofiltration of multi-component feeds. Interactions between neutral and charged components and their effect on retention, J. Membr. Sci. 247 (2005), 11-20. 


\begin{abstract}
Membrane characterization and modeling of membrane processes are essential steps in the development and implementation of new membrane filtration processes. The generalized Maxwell-Stefan equation is frequently used to describe these processes. However, predictive modeling on the basis of characterization experiments using single solutes is still troublesome in a lot of cases. Consequently, a better understanding of the effect of the interaction between different components on the membrane separation characteristics is required. In this work, four well-known commercially available membranes, Desal 5DK, Desal 5DL, Desal G5, NTR-7450, and a newly introduced membrane NF have been characterized. The pore radii of these membranes determined from glucose retention experiments increase in the following sequence: Desal $5 D K \approx N F<$ Desal $5 D L<$ Desal $G 5<N T R-7450$. The pore radii and effective membrane thickness determined on the basis of glycerin experiments are within $6 \%$ of those determined using glucose. The presence of salt ions, especially of those for which the membranes show low retention, leads to reduction of the retention of neutral components (glucose). The retention reduction, at maximum 10\% (absolute) in this study, depends on the membrane selected. For NF and Desal 5DK a high glucose retention drop coincides with a high concentration of the anion salt $\left(\mathrm{Cl}^{-}\right)$ions in the permeate, independent of the cation salt ion used. This phenomenon can be explained by several hypotheses. One of these, supported by generalized Maxwell-Stefan model calculations, is that the presence of a pore size distribution leads to the observed shift in selectivity. In the presence of salt ions in the pores, the flux through small pores is reduced to a larger extent than that in bigger pores. Consequently, the retention for glucose drops and a shift in the apparent pore radius is determined. Regardless of the mechanism that causes the reduction of the glucose retention, it is essential that this effect is incorporated in predictive models for nanofiltration to predict the loss of organic components to the permeate sufficiently accurately since this loss may affect permeate disposal costs or product yield.
\end{abstract}




\section{Introduction}

Nanofiltration membranes are a relatively new class of membranes, with properties in between those of ultrafiltration (UF) and reverse osmosis (RO) membranes. These membranes are amongst others used in the food industry for the demineralization of whey and UF whey permeates [1]. The availability of a fundamental mathematical model that would predict the separation efficiency and the capacity of a nanofiltration membrane for industrial processes would facilitate the development of new processes and the design of nanofiltration installations. Several (e.g. extended Nernst-Planck and Maxwell-Stefan) models have been or are being developed for this purpose [2-10]. In these models generally steric hindrance (sieving effect), Donnan exclusion [2,3], dielectric exclusion $[4,11]$ and/or increased solute solvation energy are assumed to be responsible for the retention of solutes by nanofiltration membranes [12].

One of the most fundamental ways to predict the transport through a nanofiltration membrane is by means of a model using the generalized Maxwell-Stefan (GMS) equations [13]. In these equations, the diffusive movement of a species is described as a result of the friction of that species with all the other components in the system. This generalized Maxwell-Stefan description attracted increased attention [8-10] after several empirical relations to calculate all the friction coefficients in a multi-component system became available in the 1990s [14-16].

The parameters required in a Maxwell-Stefan (or extended Nernst-Planck) model to describe the sieving effect and Donnan exclusion are the mean pore radius, the effective membrane thickness, and the surface charge density [2, 4, 5]. These parameters are usually obtained by fitting the model to solute retentions and membrane fluxes measured in membrane characterization experiments using pure water, single salt, and single sugar solutions [8]. When dielectric exclusion or changes in solvent structure are taken into account as well, the number of model parameters involved will of course increase [12].

With several models, e.g. the Maxwell-Stefan model as proposed by Straatsma et al. [8], the membrane performance for processing a solution containing a mixture of salts can be fitted well. However, generally the results cannot be predicted on the basis of the parameters obtained in membrane characterization experiments with single component solutions. Clearly, the interactions between different components and the 
membrane, and their effect on the separation characteristics of nanofiltration membranes, are not yet sufficiently understood [8]. In this study the membrane characteristics and the interactions between different components on the separation efficiency for five commercially available nanofiltration membranes have been investigated to get a better insight into these phenomena. Special attention has been paid to the effect of salt ions on the retention of neutral components. To evaluate the experimental results the Maxwell-Stefan model as proposed by Straatsma et al. [8] has been used. The description of concentration polarization, not used in the original Straatsma model [8], has now been implemented.

\section{Theoretical background}

The Maxwell-Stefan equation of a species $i$, worked out for one transport direction $(y)$ is:

$$
-\frac{d \mu_{i}}{d y}-V_{m, i} \cdot \frac{d P}{d y}-z_{i} \cdot F \cdot \frac{d \Phi}{d y}=\sum_{j=1}^{n}\left(x_{j} \cdot \zeta_{i, j} \cdot\left(u_{i}-u_{j}\right)\right)
$$

Straatsma et al. [8] have applied the Maxwell-Stefan equations to the interfaces at both sides of the membrane boundary and the membrane layer itself. A fourth transport layer, a stagnant layer where concentration polarization takes place, was described mathematically, but was not yet implemented in the model [8]. The common form of the Maxwell-Stefan equation (1) has now been implemented in Straatsma's model [8] to describe the transport through this layer.

For the calculation of the solute concentration at the membrane surface, the layer thickness is required. This thickness strongly depends on the flow intensity along the membrane and membrane characteristics like porosity and roughness [17]. On the basis of the film model theory [18], the thickness can be calculated from:

$$
S h=\frac{k \cdot L}{D}=\frac{L}{\delta_{l}}
$$

Many empirical correlations have been proposed to calculate the Sherwood number (Sh) [19]. One of the most popular correlations for turbulent flow is described by [19]: 
$S h=0.023 \cdot R e^{0.8} \cdot S c^{0.33}$

The concentration polarization layer thickness $\left(\delta_{l}\right)$ calculated for the flat sheet membranes used in our experiments varied from $1 \cdot 10^{-5}$ to $3 \cdot 10^{-5} \mathrm{~m}$. Because the exact flow characteristics of the membrane module used are insufficiently known and would require a separate study to determine, we have used $2 \cdot 10^{-5} \mathrm{~m}$ as an estimate for the concentration polarization layer thickness in the updated (GMS) model for all experiments described.

As in the original Straatsma model the membrane charge $Q_{m}$ has been calculated using the Freundlich isotherm [8]:

$Q_{m}=Q_{0}\left(\sum_{i}\left|z_{i}\right| x_{i}\right)^{K_{s}}$

\section{Experimental work \\ 3.1. Membranes}

Retention experiments were carried out with five different commercially available nanofiltration membranes (Desal 5DK, Desal 5DL, Desal G5, NF, and NTR-7450). Desal 5DK and Desal 5DL (Osmonics, USA) are three-layer thin film polysulfone based membranes with a polyamide top layer. Desal G5 (Osmonics, USA) is a two-layer thin film polysulfone based membrane with a polyamide top layer. NF (DOW Chemicals, USA) is a three-layer polysulfone based membrane with a polypiperazine top layer. This membrane was introduced recently and replaces the well known NF-45 and NF-70 membranes. NTR-7450 (Nitto Denko, Shiga, Japan) is a sulfonated polyethersulfone membrane. The molecular weight cut-offs (MWCO) of these membranes as reported by the suppliers are listed in Table 1. 
Table 1: Molecular weight cut-off (MWCO) of nanofiltration membranes as reported by suppliers.

\begin{tabular}{cc}
\hline Membrane & $\begin{array}{c}\text { MWCO } \\
(\mathrm{Da})\end{array}$ \\
\hline Desal 5DK & 200 \\
Desal 5DL & 400 \\
Desal G5 & 1000 \\
NF & $<200$ \\
NTR 7450 & 1000 \\
\hline
\end{tabular}

\subsection{Model solutions}

The neutral solutes used in the experiments were glucose (Brunschwig Chemie, the Netherlands) and glycerin (SIGMA, USA). The salts used were $\mathrm{NaCl}, \mathrm{KCl}$, and $\mathrm{CaCl}_{2}$ (Merck, Germany). The properties of the neutral solutes and the salts are listed in Table 2. All feeds used in the test were obtained by dissolving these components in RO permeate of tap water (see section 3.5).

Table 2: Diffusivities and Stokes radii of ions and neutral solutes

\begin{tabular}{cccc}
\hline Ions/ Solutes & $\begin{array}{c}A W \text { or } M W \\
\left(\mathrm{~g} \mathrm{~mol}^{-1}\right)\end{array}$ & $\begin{array}{c}D_{\infty} \\
\left(\mathrm{m}^{2} \mathrm{~s}^{-1}\right) \times 10^{-9}\end{array}$ & $\begin{array}{c}r_{s} \\
(\mathrm{~nm})\end{array}$ \\
\hline $\mathrm{K}^{+}$ & 39.1 & 1.95 & 0.125 \\
$\mathrm{Na}^{+}$ & 23 & 1.33 & 0.161 \\
$\mathrm{Cl}^{-}$ & 35.5 & 2.03 & 0.106 \\
$\mathrm{Ca}^{2+}$ & 40 & 0.78 & 0.233 \\
Glycerin & 92 & 0.81 & 0.264 \\
Glucose & 180 & 0.60 & 0.360 \\
\hline
\end{tabular}

$A W=$ Atomic weight, $M W=$ Molecular weight 


\subsection{Apparatus}

Retention experiments were carried out using a DDS Lab 20 unit as described by Van der Horst et al. [7]. The experiments were performed in batch circulation mode, recycling both the retentate and permeate to the feed tank. Four membranes at maximum were placed in series, each membrane having a surface area of $0.036 \mathrm{~m}^{2}$. From top to bottom in the module the following membranes were installed: Desal 5DK, NF, Desal 5DL, and NTR-7450. Desal G5 was tested separately. The solute concentrations in the feed to the last membrane in the series, as determined on the basis of mass balance and solute balance calculations, differed by less than $2 \%$ from those of the feed to the first membrane in the series. Furthermore the cross-flow velocity was practically constant throughout the module (see section 3.5 ). Therefore the position of the membrane in the module had no significant effect on the results obtained.

\subsection{Analyses}

Glucose concentrations were measured with a polarimeter from Perkin-Elmer. Glycerin concentrations were analyzed by HPLC using a Carbohydrates-Pb column (Varian) and refractive index detection. The salt concentrations were analyzed by conductivity measurements with a Metrohm conductometer.

\subsection{Experimental conditions}

Prior to the experiments the membranes were pre-compacted by increasing the pressure to 40 bar and maintaining circulation operation at this pressure, until the flux of the individual membranes remained constant for at least $30 \mathrm{~min}$. During pre-compaction at a temperature of $20^{\circ} \mathrm{C}, \mathrm{RO}$ permeate of tap water was used as feed.

The temperature and cross-flow velocity during all experiments were $20.0 \pm 0.5^{\circ} \mathrm{C}$ and $0.9 \mathrm{~m} \mathrm{~s}^{-1}$, respectively. Since the combined permeate flow of the membranes was always less than $5 \%$ of the retentate flow, the cross-flow velocity was practically equal for all membranes. The pressure-drop along the module was below $0.1 \mathrm{MPa}$ in all cases.

Pure water fluxes were measured using RO permeate of tap water to determine the permeability of individual membranes. The pressure was varied between 0.2 and 4.0 MPa. 
Retention experiments were carried out at outlet pressures ranging from 0.2 to $3 \mathrm{MPa}$. After each pressure adjustment, at least $30 \mathrm{~min}$. was allowed for equilibrium to be reached. At each pressure, the temperature, permeate flux, and permeate composition were determined.

Retention experiments with solutions containing neutral components (glucose or glycerin) were carried out to determine, in combination with the results of the pure water flux experiments, the pore radius and the effective thickness of the membranes. Feed solutions contained $1.5 \mathrm{~g} \mathrm{~kg}^{-1}$ glucose or $3 \mathrm{~g} \mathrm{~kg}^{-1}$ glycerin. The glucose concentrations of the permeates and retentate were measured (see section 3.4) directly and the samples were put back in the feed tank to keep the feed composition unchanged. To investigate whether the two neutral solutes would affect each other's retention, an experiment with $1.5 \mathrm{~g} \mathrm{~kg}^{-1}$ glucose and $1.5 \mathrm{~g} \mathrm{~kg}^{-1}$ glycerin was carried out.

To investigate the influence of the presence of salts on the glucose retention, experiments were carried out using feeds with a glucose concentration of $1.5 \mathrm{~g} \mathrm{~kg}^{-1}$ in combination with $\mathrm{NaCl}, \mathrm{CaCl}_{2}$ or $\mathrm{KCl}$. The salt concentrations used in these tests were 0.01-1.0 M, 0.005-0.05 M, and 0.1 M for $\mathrm{NaCl}, \mathrm{CaCl}_{2}$, and $\mathrm{KCl}$, respectively. During the entire set of experiments only one flat sheet per membrane type was used. Prior to the experiments with different solutions pure water fluxes of the individual membranes were determined at $1 \mathrm{MPa}$ and $2 \mathrm{MPa}$ to evaluate whether the membrane had changed or fouling had occurred during the previous experiment. Since the variation in the pure water flux of the individual membranes was $10 \%$ at maximum (and in most cases far less) during the entire experimental program, it is assumed that the condition of the membranes did not change significantly. Furthermore, the variation in the pure water flux of the individual membranes did not show a specific (e.g. reducing) trend with progressing of the experimental program, apart from NTR-7450, for which a gradual reduction of the pure water flux with progressing of the run was observed.

\section{Results and discussion}

\subsection{Pure water permeabilities of the membranes}

On the basis of pure water flux measurements, the permeabilities determined for NTR7450, Desal 5DL, NF, Desal 5DK, and Desal G5 are 2.05.10-11, $1.58 \cdot 10^{-11}, 1.53 \cdot 10^{-11}$, 
$1.42 \cdot 10^{-11}$, and $0.25 \cdot 10^{-11} \mathrm{~m} \mathrm{~s}^{-1} \mathrm{~Pa}^{-1}$ respectively (see Fig. 1 for pure water permeabilities of NTR-7450, NF, and Desal G5).

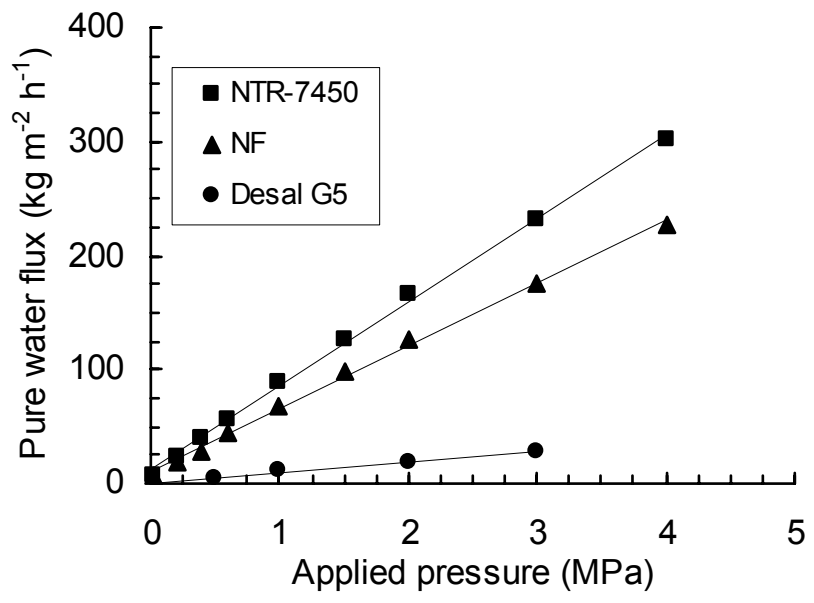

Figure 1: Pure water flux as a function of the applied pressure.

Table 3: Pure water permeabilities reported for Desal 5DK, Desal 5DL, and NTR7450

\begin{tabular}{ccc}
\hline Membrane & $\begin{array}{c}\text { Pure water permeability } \\
\left(\mathrm{m} \mathrm{s}^{-1} \mathrm{~Pa}^{-1}\right)\end{array}$ & Published by \\
\hline Desal 5DK & $1.4 \cdot 10^{-11}$ & Bowen and Mohammad \\
& & {$[20]$} \\
Desal 5DK (first batch) & $2.2 \cdot 10^{-11}$ & Hagmayer and Gimbel [4] \\
Desal 5DK (second batch) & $1.7 \cdot 10^{-11}$ & Hagmayer and Gimbel [4] \\
Desal 5DK & $1.3 \cdot 10^{-11}$ & Straatsma et al. [8] \\
Desal 5DK & $1.5 \cdot 10^{-11}$ & This work \\
Desal 5DL & $2.1 \cdot 10^{-11}$ & Bowen and Mohammad \\
& & [20] \\
Desal 5DL & $1.6 \cdot 10^{-11}$ & This work \\
NTR-7450 & $2.6 \cdot 10^{-11}$ & Bowen and Mohammad \\
& & [20] \\
NTR-7450 & $6.4 \cdot 10^{-11}$ & Schaep et al. [21] \\
NTR-7450 & $2.1 \cdot 10^{-11}$ & This work \\
\hline
\end{tabular}


The pure water permeability obtained for Desal 5DK is reasonably in line with those reported by Bowen and Mohammad [20] and Straatsma et al. [8]. Hagmayer and Gimbel [4] presented permeabilities for Desal 5DK that are more in line with those of Desal 5DL as found by Bowen and Mohammad [20] and in this study (see Table 3). The pure water permeability determined in this study for NTR-7450 is around $30 \%$ lower than that reported by Bowen and Mohammad [20]. Schaep et al. [21] presented a pure water permeability 2.5 times higher than that found by Bowen and Mohammad. Possible explanations for these differences in pure water permeabilities may be differences in pre-compaction procedures of the membranes (not always presented by the various authors), measurement of the pure water permeability at only one pressure in other studies, the module configuration used and the representativeness of the small membrane sheets used.

\subsection{Membrane characterization using uncharged solutes}

The glucose retentions for Desal 5DK, NF, and Desal 5DL are significantly higher than those for Desal G5 and NTR 7450 (Fig. 2 and Fig. 3), as expected on the basis of the MWCO values reported by the suppliers for these membranes (see Table 1). Surprisingly, there is a significant difference in glucose retention between Desal G5 and NTR-7450, despite the similar MWCO (1 kDa) as reported by their suppliers.

The mean pore size $\left(r_{p}\right)$ and the effective membrane thickness $\left(\delta_{m}=d_{m}{ }^{*} T / \varepsilon\right)$ for the membranes, calculated through fitting of the experimental flux and glucose retention results using the four layer (including concentration polarization) GMS model, are listed in Table 4. In this fitting procedure the effect of the membrane charge and the electrical forces on the transport of this neutral component are neglected $\left(z_{i}=0\right.$ in equation 4$)$.

Desal 5DK and NF have the smallest pore size, whereas Desal 5DL appears to be slightly more open. The effective membrane thickness for these three membranes is practically equal. The high flux of Desal $5 \mathrm{DL}$ as compared to Desal $5 \mathrm{DK}$ and NF is therefore mainly due to the bigger main pore radius of Desal $5 \mathrm{DL}$. The fitted mean pore radius and effective membrane thickness for Desal 5DK and NF as obtained from glycerin retention experiments deviate by less than $6 \%$ from those determined on the basis of glucose experiments (see Table 4). The retention data for NF using a solution containing $1.5 \mathrm{~g} \mathrm{~kg}^{-1}$ glucose and a solution containing $3.0 \mathrm{~g} \mathrm{~kg}^{-1}$ glycerin are shown in Fig. 3. The continuous lines are the fitted flux retention curves for glycerin and glucose 
resulting in the $r_{p}$ and $\delta_{m}$ as listed in Table 4 . The dashed lines show the model predictions for the uncharged solutes on the basis of the $r_{p}$ and $\delta_{m}$ determined using the other uncharged solute. As can be seen from Fig. 3, the solute retention can be predicted sufficiently accurately, even when a pore radius and effective membrane thickness determined for the other neutral solute are used. The marginal difference in the membrane characteristics found from the glucose and glycerin characterization may be due to a slight deviation of the actual Stokes radius for glucose and/or glycerin from the theoretical values as given in Table 2 .

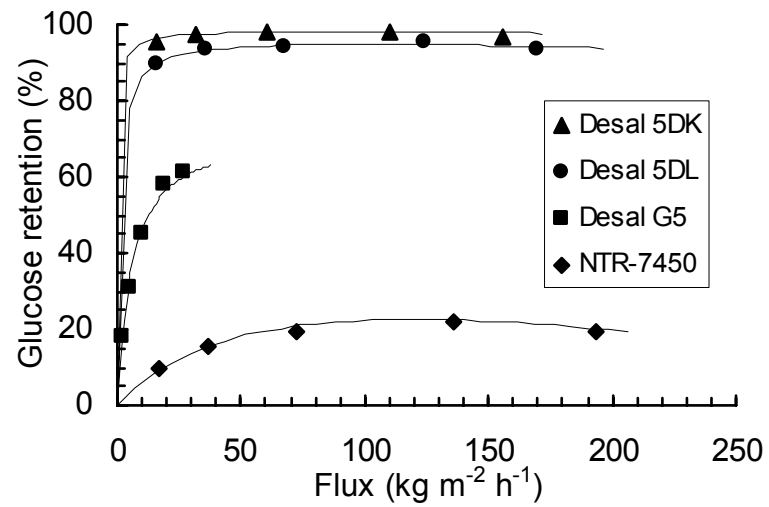

Figure 2: Glucose retention as a function of flux for Desal 5DK, Desal 5DL, Desal G5, and NTR-7450. Symbols are measured results; lines are model fitted curves.

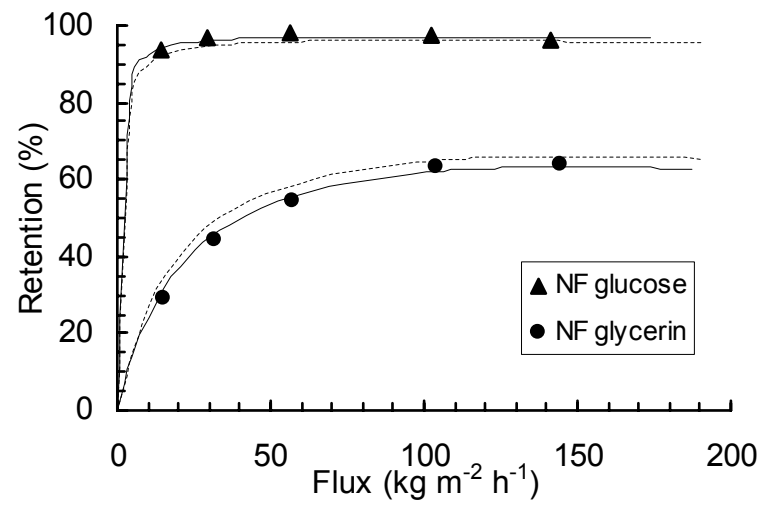

Figure 3: The retention of the NF membrane for glucose and glycerin as a function of the permeate flux. Uninterrupted lines are based on the fitted $r_{p}$ and $\delta_{m}$. Dashed lines are model predictions based on the $r_{p}$ and $\delta_{m}$ fitted for the other component. 
Table 4: Results of membrane characterization with uncharged solutes

\begin{tabular}{ccccc}
\hline & \multicolumn{2}{c}{ Glucose } & \multicolumn{2}{c}{ Glycerin } \\
Membrane & $r_{p}(\mathrm{~nm})$ & $\delta_{m}(\mu \mathrm{m})$ & $r_{p}(\mathrm{~nm})$ & $\delta_{m}(\mu \mathrm{m})$ \\
\hline NTR-7450 & 1.34 & 11.69 & - & - \\
Desal G5 & 0.84 & 40.54 & - & - \\
Desal 5DL & 0.45 & 2.54 & - & - \\
NF & 0.43 & 2.47 & 0.44 & 2.62 \\
Desal 5DK & 0.42 & 2.59 & 0.44 & 2.74
\end{tabular}

The mean pore radius determined for Desal $5 \mathrm{DK}$ is slightly lower $(0.42 \mathrm{~nm}$ vs. $0.46 \mathrm{~nm})$ than previously reported by Straatsma et al. [8], using their three layer model. The current result is considered to be more accurate, since more experimental data points were used, especially at relatively low fluxes, and concentration polarization is now taken into account. Bowen and Mohammad [20] reported pore radii for Desal 5DK and Desal 5DL in excess of $0.5 \mathrm{~nm}$. In their estimation the pore size was based on an assumed MWCO for these membranes of 225 Da. Furthermore, concentration polarization was not taken into account in their calculation.

Desal G5 and NTR-7450, both reported by the manufacturers to have a MWCO of 1 $\mathrm{kDa}$, are the most open membranes. Desal G5 has a very low permeate flux compared to NTR-7450. This is partly caused by a lower mean pore size, but mainly by a much higher effective membrane thickness (see Table 4). The mean pore radius for NTR7450 is slightly lower than that reported by Bowen and Mohammad $\left(r_{p}=1.41 \mathrm{~nm}\right.$ [20]). Schaep et al. [21] reported mean pore radii for NTR-7450 of $0.55 \mathrm{~nm}, 0.71 \mathrm{~nm}$, and $0.80 \mathrm{~nm}$ for solutions containing galactose, maltose, and raffinose, respectively. Timmer reported a lower pore radius for NTR-7450 (0.76 nm [22] and $0.82 \mathrm{~nm}$ [23]) on the basis of Paselli MD6 (glucose polymers with a sugar radius between 0.5 and $1.2 \mathrm{~nm}$ ) solution experiments and using the well-known Ferry equation. Also Wang et al. [24] reported a pore radius $(0.70 \mathrm{~nm})$ more in line with that found by Timmer et al. [22] and Schaep et al. [21]. The reason for the large spread in reported pore radii is not known.

\subsection{Prediction of retention for a solution containing glycerin and glucose}

The glucose and glycerin retention for NF and Desal 5DK predicted for a $1.5 \mathrm{~g} \mathrm{~kg}^{-1}$ glucose solution, a $3.0 \mathrm{~g} \mathrm{~kg}^{-1}$ glycerin solution, and a solution containing $1.5 \mathrm{~g} \mathrm{~kg}^{-1}$ glucose and $1.5 \mathrm{~g} \mathrm{~kg}^{-1}$ glycerin on the basis of average pore radius and effective 
membrane thickness as determined using a $3.0 \mathrm{~g} \mathrm{~kg}^{-1}$ glycerin solution are shown in Fig. 4 and 5, respectively. For both membranes the measured glucose retention with or without glycerin being present in the solution is predicted well by the model. This retention is hardly influenced by the presence of glycerin (see Fig. 4 and 5). The glycerin retention appears to be higher when part of the glycerin is replaced by glucose. The model predicts higher glycerin retention, since the friction between glycerin and glucose in the solution and in the membrane pores is higher than the friction between individual glycerin molecules, but the observed difference is higher than predicted by the model, especially for NF.

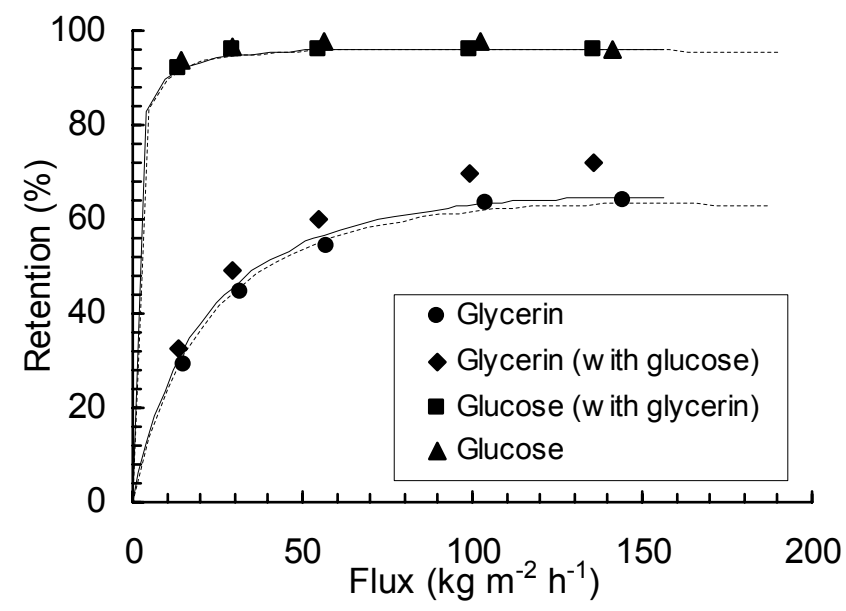

Figure 4: Measured (symbols) and predicted glycerin and glucose retention for NF. Predicted values for single sugar (glycerin or glucose) solutions presented with dashed lines; predicted values for mixed sugar (glycerin and glucose) solutions presented with full lines. 


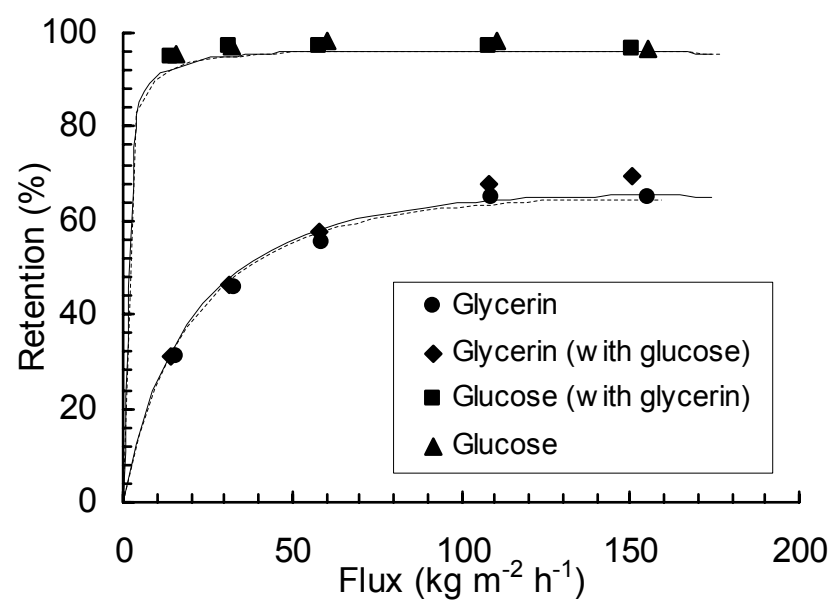

Figure 5: Measured (symbols) and predicted glycerin and glucose retention for Desal 5DK. Predicted values for single sugar (glycerin or glucose) solutions presented with dashed lines; predicted values for mixed sugar (glycerin and glucose) solutions presented with full lines.

\subsection{The effect of salt on glucose retention}

The effect of the presence of salt in the feed solution on the membrane characteristics for NF, Desal 5 DK and NTR-7450 was determined by measuring glucose retentions in the presence of different salts and using different salt concentrations. The salt retentions were measured as well, to determine the charge characteristics of the membrane, required for the prediction of the glucose retention in the presence of salt. Generally, the $\mathrm{NaCl}$ retention decreases with increasing salt concentration (see e.g. Fig. 6). The Freundlich parameters $Q_{0}$ and $K_{s}$ (see section 2) fitted for each membrane using the mean pore size obtained from glucose experiments without salt (Table 4) are summarized in Table 5. The measured $\mathrm{NaCl}$ retentions could be fitted well (see Fig. 6 for the fit results for NF).

The measured glucose retentions for NF using a $1.5 \mathrm{~g} \mathrm{~kg}^{-1}$ glucose feed solution with different $\mathrm{NaCl}$ concentrations are compared with model predictions (using $r_{p}=0.43 \mathrm{~nm}$, $\delta_{m}=2.47 \mu \mathrm{m}, Q_{0}=-1.9 \cdot 10^{4} \mathrm{~mol} \mathrm{~m}^{-3}$, and $\left.K_{s}=0.17\right)$ in Fig. 7. The model predicts the observed flux decrease when higher salt concentrations are used (see Table 6); however, calculated fluxes still deviate by up to around $20 \%$ from measured flux values. 
An increase in salt concentration increases the membrane charge density and consequently the friction between the components (including water) in the membrane. This results in a lower flux. On the basis of the model predictions it is expected that an increase in $\mathrm{NaCl}$ concentration would cause a slight increase of the glucose retention (see Fig.7). However, the experimental results show an opposite effect. Not only the salt retention, but also the glucose retention gradually decreases with increasing $\mathrm{NaCl}$ concentration. For a feed solution containing $1.0 \mathrm{M} \mathrm{NaCl}$, the decrease in glucose retention, as compared to a solution without $\mathrm{NaCl}$, is as high as $10 \%$.

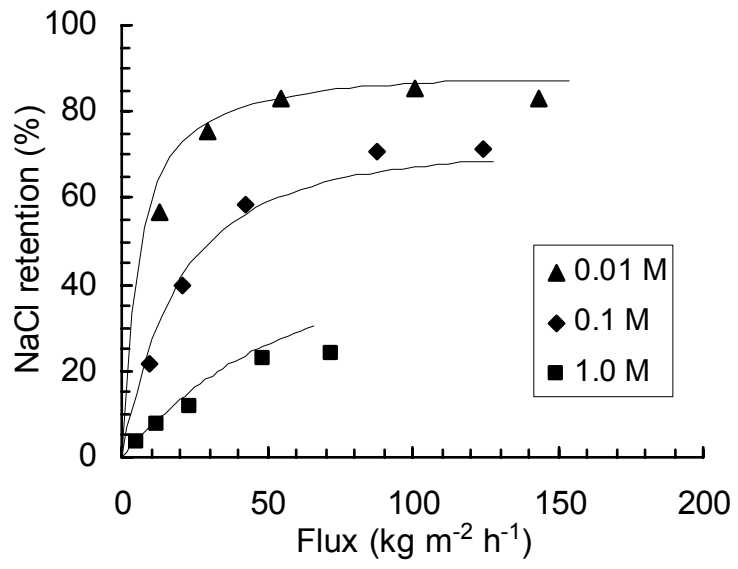

Figure 6: $\mathrm{NaCl}$ retention for $\mathrm{NF}$ as a function of flux at different $\mathrm{NaCl}$ concentrations in the presence of $0.15 \%$ glucose, using $Q_{0}=-1.9 \cdot 10^{4} \mathrm{~mol} \mathrm{~m}^{-3}$, and $K_{s}=0.17$. Lines represent model predictions.

Table 5: Freundlich parameters used in the model

\begin{tabular}{cccc}
\hline Membrane & Salt & $Q_{0}\left(\mathrm{~mol} \mathrm{~m}^{-3}\right)$ & $K_{s}$ \\
\hline Desal 5DK & $\mathrm{NaCl}$ & $-3.5 \cdot 10^{4}$ & 0.3 \\
& $\mathrm{KCl}$ & $-4.1 \cdot 10^{4}$ & 0.3 \\
& $\mathrm{CaCl}_{2}$ & $5.5 \cdot 10^{6}$ & 0.6 \\
$\mathrm{NF}$ & $\mathrm{NaCl}$ & $-1.9 \cdot 10^{4}$ & 0.17 \\
& $\mathrm{KCl}$ & $-2.1 \cdot 10^{4}$ & 0.17 \\
& $\mathrm{CaCl}_{2}$ & $1.6 \cdot 10^{5}$ & 0.6 \\
$\mathrm{NTR}-7450$ & $\mathrm{NaCl}$ & $-1.9 \cdot 10^{3}$ & 0.16 \\
& $\mathrm{KCl}$ & $-1.5 \cdot 10^{3}$ & 0.16 \\
& $\mathrm{CaCl}_{2}$ & $-1.3 \cdot 10^{3}$ & 0.16 \\
\hline
\end{tabular}




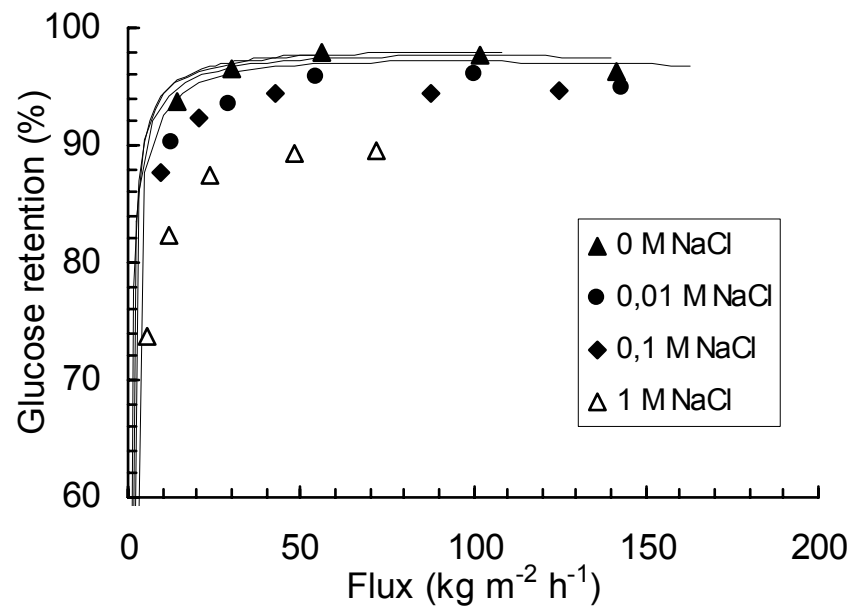

Figure 7: Glucose retention for NF as function of the flux for feeds containing glucose and $\mathrm{NaCl}$ with different $\mathrm{NaCl}$ concentrations (see legends). Continuous lines are model predictions using $r_{p}=0.43 \mathrm{~nm}, Q_{0}=-1.9 \cdot 10^{4} \mathrm{~mol} \mathrm{~m}^{-3}$, and $K_{s}=0.17$.

Table 6: Measured and predicted (using $r_{p}=0.43 \mathrm{~nm}, Q_{0}=-1.9 \cdot 10^{4} \mathrm{~mol} \mathrm{~m}^{-3}$ and $K_{s}=0.17$ ) fluxes for $\mathrm{NF}$ at $\mathrm{P}=30$ bar.

\begin{tabular}{cccc}
\hline $\begin{array}{c}\mathrm{NaCl} \\
\text { concentration } \\
(\mathrm{M})\end{array}$ & Predicted flux & Measured flux & Deviation \\
\hline 0 & $\left(\mathrm{~kg} \mathrm{~m}^{-2} \mathrm{~h}^{-1}\right)$ & $\left(\mathrm{kg} \mathrm{m}^{-2} \mathrm{~h}^{-1}\right)$ & $(\%)$ \\
0.01 & 163 & 141 & -16 \\
0.1 & 140 & 143 & 2 \\
1.0 & 108 & 124 & 13 \\
\hline
\end{tabular}

The decrease in glucose retention at increasing $\mathrm{NaCl}$ concentration can only be described accurately by adjusting the value of the mean pore size of the membranes in the model. The fitted values for the mean pore size and the effective membrane thickness for the different membranes at different $\mathrm{NaCl}$ concentrations are shown in Table 7. For all three membranes tested the fitted pore sizes increase when the $\mathrm{NaCl}$ concentration is increased. For NTR-7450 this increase in pore size is relatively large, whereas for Desal 5DK only a minor increase is found, since the glucose retention for 
the latter membrane is less dependent on the salt content of the feed. Vellenga and Trägård [25] also studied the effect of combined sugar and salt solutions on the sugar retention for Desal 5 (DS5). They did not observe any effect of the presence of $\mathrm{NaCl}$ on the sugar retention for Desal 5. This may seem to contradict with the results found in this study, however it should be noted that they used sucrose/ $\mathrm{NaCl}$ mixtures in their study. Sucrose has a higher molecular weight than glucose and therefore shows much higher retention. It is therefore expected that a slight increase in mean pore size as consequence of an increased amount of $\mathrm{NaCl}$ in the feed (as found for Desal 5DK in this study) affects the glucose retention to a larger extend than the sucrose retention. Since the glucose retention for Desal 5DK only changed little when $1.0 \mathrm{M} \mathrm{NaCl}$ was added to the solution, an unchanged sucrose retention would not be unexpected. Vellenga and Trägård [25] also reported that the observed high retention of sucrose could have hidden influences on transport phenomena.

Table 7: Results of membrane characterization with $1.5 \mathrm{~g} \mathrm{~kg}^{-1}$ glucose in the presence of different $\mathrm{NaCl}$ concentrations.

\begin{tabular}{lllllll}
\hline & \multicolumn{2}{l}{$\mathrm{NTR}-7450$} & $\mathrm{NF}$ & \multicolumn{2}{l}{ Desal 5DK } \\
$\mathrm{cNaCl}$ & $r_{p}$ & $\delta_{m}$ & $r_{p}$ & $\delta_{m}$ & $r_{p}$ & $\delta_{m}$ \\
$(\mathrm{M})$ & $(\mathrm{nm})$ & $(\mu \mathrm{m})$ & $(\mathrm{nm})$ & $(\mu \mathrm{m})$ & $(\mathrm{nm})$ & $(\mu \mathrm{m})$ \\
\hline 0 & 1.34 & 11.7 & 0.43 & 2.47 & 0.42 & 2.59 \\
0.01 & 1.70 & 18.4 & 0.45 & 2.62 & 0.43 & 2.66 \\
0.1 & 2.30 & 33.0 & 0.46 & 2.69 & 0.43 & 2.66 \\
1.0 & 2.25 & 31.7 & 0.48 & 2.84 & 0.44 & 2.74 \\
\hline
\end{tabular}

When glucose solutions containing $\mathrm{CaCl}_{2}$ or $\mathrm{KCl}$ are used, a reduction of the glucose retention as compared to a situation where salt is absent is also observed (see Fig. 8 and Fig. 9 for NF and NTR-7450, respectively). In the presence of $0.05 \mathrm{M} \mathrm{CaCl}_{2}$ this reduction is small for $\mathrm{NF}$, whereas for $0.1 \mathrm{M} \mathrm{KCl}$ the decline in glucose retention (approximately $5 \%$ ) is only marginally higher than that found for a glucose solution containing $0.1 \mathrm{M} \mathrm{NaCl}$. For NTR-7450 a similar pattern is observed. The presence of $0.05 \mathrm{M} \mathrm{CaCl}_{2}$ in the $0.15 \%$ glucose solution hardly affects the glucose retention, whereas the presence of $0.1 \mathrm{M} \mathrm{KCl}$ in the $0.15 \%$ glucose solution reduces the glucose retention to $50 \%$ of the retention found for the $0.15 \%$ glucose solution that does not contain any salt. The mean pore size and the effective membrane thickness, fitted on 
the basis of glucose retention in the presence of different salts at equal chloride concentration in the feed, are summarized in Table 8.

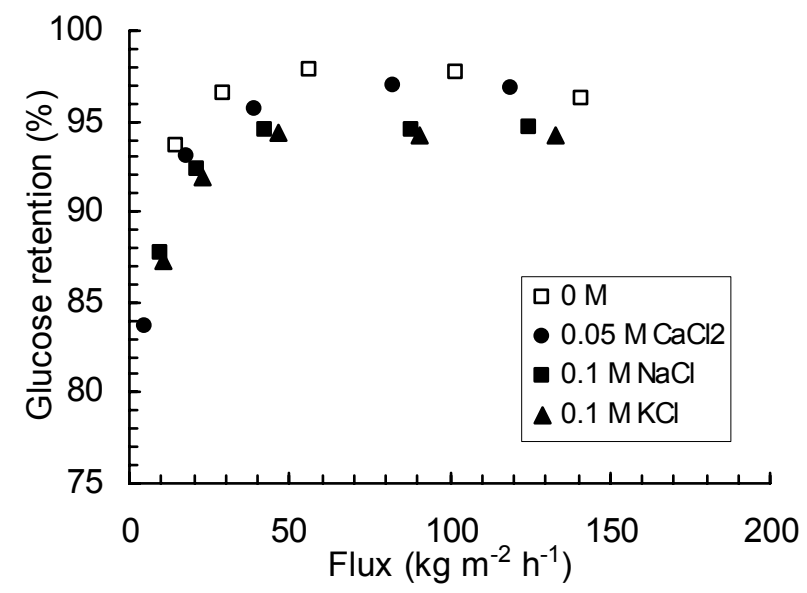

Figure 8: Glucose retention for feeds containing, apart from $0.15 \%$ glucose, different salts (see legends) as function of the flux for NF.

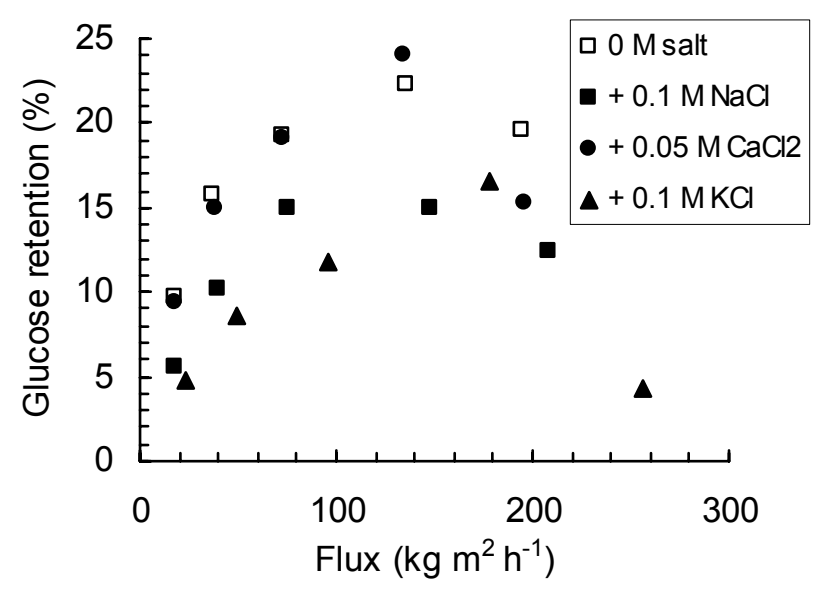

Figure 9: Glucose retention for feeds containing, apart from $0.15 \%$ glucose, different salts (see legends) as function of the flux for NTR-7450. 
Table 8: Results of membrane characterization with $1.5 \mathrm{~g} \mathrm{~kg}^{-1}$ glucose in the presence of different salts.

\begin{tabular}{|c|c|c|c|c|c|c|}
\hline \multirow[b]{2}{*}{ Salt } & \multicolumn{2}{|c|}{ NTR-7450 } & \multicolumn{2}{|l|}{ NF } & \multicolumn{2}{|c|}{ Desal 5DK } \\
\hline & $\begin{array}{l}r_{p} \\
(\mathrm{~nm})\end{array}$ & $\begin{array}{l}\delta_{m} \\
(\mu \mathrm{m})\end{array}$ & $\begin{array}{l}r_{p} \\
(\mathrm{~nm})\end{array}$ & $\begin{array}{l}\delta_{m} \\
(\mu \mathrm{m})\end{array}$ & $\begin{array}{l}r_{p} \\
(\mathrm{~nm})\end{array}$ & $\begin{array}{l}\delta_{m} \\
(\mu \mathrm{m})\end{array}$ \\
\hline $0.1 \mathrm{M} \mathrm{NaCl}$ & 2.30 & 33.0 & 0.46 & 2.69 & 0.43 & 2.66 \\
\hline $0.05 \mathrm{M} \mathrm{CaCl}_{2}$ & 1.45 & 13.6 & 0.44 & 2.54 & 0.43 & 2.66 \\
\hline $0.1 \mathrm{M} \mathrm{KCl}$ & $>3$ & $>55$ & 0.47 & 2.77 & 0.44 & 2.74 \\
\hline
\end{tabular}

For all three membranes addition of salts result in an increase in the fitted mean pore size $\left(r_{p}\right)$ as compared to the mean pore size fitted with only glucose. The smallest effect is seen in the presence of $\mathrm{CaCl}_{2}$. For Desal $5 \mathrm{DK}$ only a minor increase is observed for all three salts. Simultaneously measured salt retentions for NF using solutions containing $1.5 \mathrm{~g} \mathrm{~kg}^{-1}$ glucose and $0.1 \mathrm{M} \mathrm{Cl}^{-}$are shown in Fig. 10. The $\mathrm{CaCl}_{2}$ retention for $\mathrm{NF}$ is considerably higher than that for $\mathrm{NaCl}$ and $\mathrm{KCl}$. Since the glucose retention reduction, when $\mathrm{CaCl}_{2}$ is added to the solution, is relatively low as compared to addition of $\mathrm{NaCl}$ and $\mathrm{KCl}$, apparently there is a positive correlation between the glucose and salt retention (Fig. 8 and 10) at similar $\mathrm{Cl}^{-}$concentration in the feed. Independent of the $\mathrm{Cl}^{-}$ concentration in the feed and the type of cation used, for NF and Desal 5DK the decline in glucose retention (and consequently the fitted mean pore radius) appears to correlate well with the $\mathrm{Cl}^{-}$concentration in the permeate (see Fig. 11 for NF and Fig. 12 for Desal $5 \mathrm{DK}$, where glucose retentions at a permeate flux of $75 \pm 5 \mathrm{~kg} \mathrm{~m}^{-2} \mathrm{~h}^{-1}$ are shown as a function of the $\mathrm{Cl}^{-}$concentration in the permeate). For both NF and Desal 5 DK the presence of relatively low $\mathrm{Cl}^{-}$concentrations in the permeate already leads to a significant decrease of the glucose retention. For NTR-7450, the relation between glucose retention and $\mathrm{Cl}^{-}$concentration in the permeate, as found for NF and Desal $5 \mathrm{DK}$, is less evident. The $\mathrm{Cl}^{-}$concentration in the permeate increases when $\mathrm{KCl}$ is used instead of $\mathrm{NaCl}$, giving lower glucose retention (see Fig. 9), as for the other two membranes (see Fig. 10 and Fig. 11).

However, for a glucose solution containing $0.05 \mathrm{M} \mathrm{CaCl}_{2}$ a relatively low $\mathrm{Cl}^{-}$ concentration in the permeate, as compared to those for $0.1 \mathrm{M} \mathrm{NaCl}$ and $0.1 \mathrm{M} \mathrm{KCl}$ containing solutions, is found at low flux only. At high flux operation relatively low $\mathrm{CaCl}_{2}$ retention and consequently relatively high $\mathrm{Cl}^{-}$concentrations in permeate (as compared to those for $\mathrm{NaCl}$ and $\mathrm{KCl}$ ) are found. Despite these high $\mathrm{Cl}^{-}$concentrations in permeate 
the glucose retention is hardly different from that found for the glucose feed without salt added (see Fig. 9).

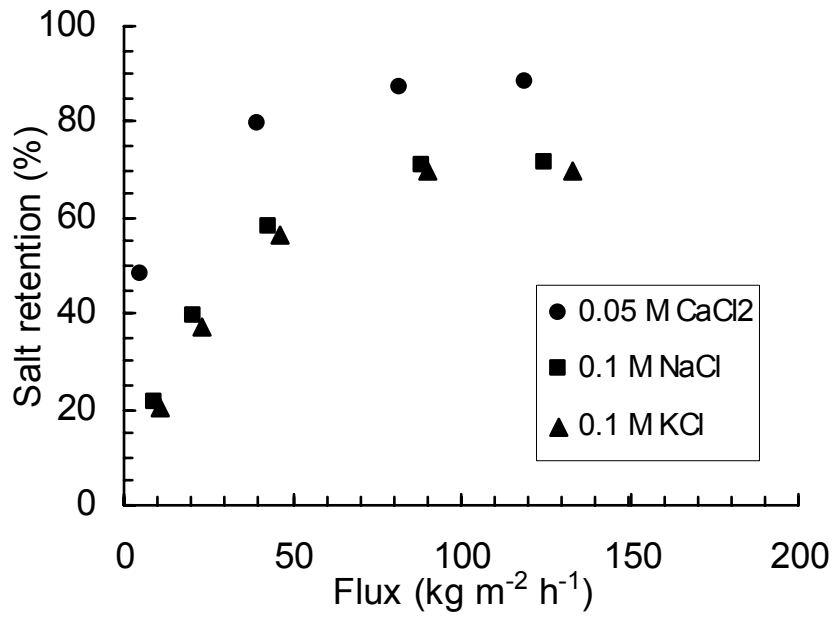

Figure 10: The salt retention for different salts as a function of the flux for NF using feeds containing salt and $0.15 \%$ glucose.

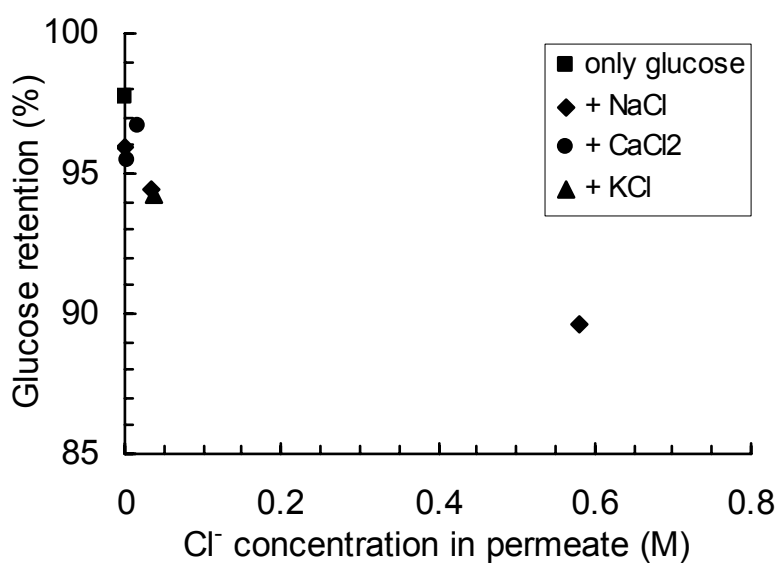

Figure 11: Glucose retention as a function of the chloride concentration in the permeate for NF at $J=75 \pm 5 \mathrm{~kg} \mathrm{~m}^{-2} \mathrm{~h}^{-1}$ using feeds containing either glucose, glucose with $\mathrm{KCl}$, glucose with $\mathrm{NaCl}$ or glucose with $\mathrm{CaCl}_{2}$ (see legends).

Several hypothetical explanations can be given for the observed effect of salt on glucose retention. Two of these will be discussed in more detail. The presence of high 
salt concentrations in the pores of the membrane generally results in a higher surface charge in the membrane pores, as predicted by the model. Furthermore, a higher concentration of counter-ions will be present in the electrical double layer in the pores. The higher repulsion forces, due to the presence of these charges, may result in swelling of the pores (higher pore radii) and consequently lead to reduced retention of neutral components.

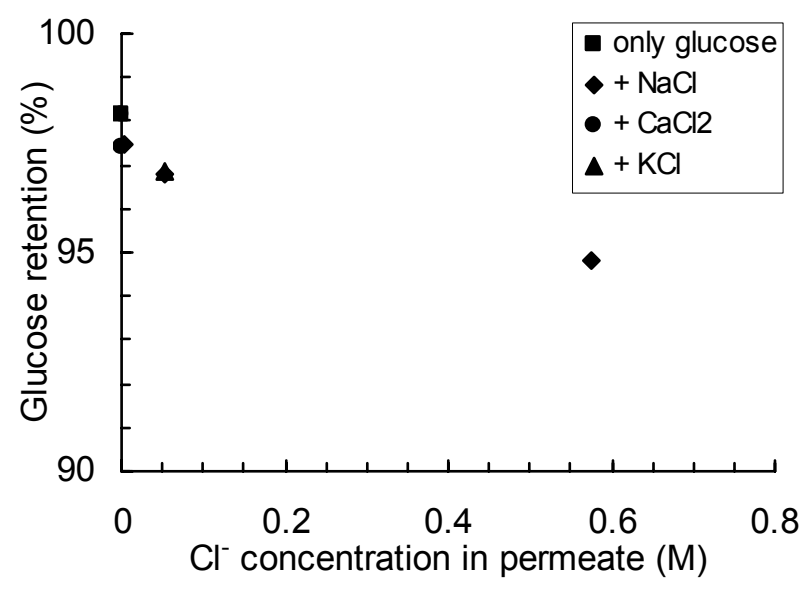

Figure 12: Glucose retention as a function of the chloride concentration in the permeate for Desal 5DK at $J=75 \pm 5 \mathrm{~kg} \mathrm{~m}^{-2} \mathrm{~h}^{-1}$ using feeds containing either glucose, glucose with $\mathrm{KCl}$, glucose with $\mathrm{NaCl}$ or glucose with $\mathrm{CaCl}_{2}$ (see legends).

An exception in swelling behavior may be NTR-7450. Schaep et al. [3] found that the charge of this membrane was very low and practically independent of the concentration of the di-valent cation, using feed solutions with $\mathrm{MgCl}_{2}$ concentrations ranging between 25 and $375 \mathrm{~mol} \mathrm{~m}^{-3}$. The membrane was charged and this charge depended on the concentration when a feed solution containing a monovalent cation $\left(50-750 \mathrm{~mol} \mathrm{~m}^{-3}\right.$ $\mathrm{NaCl}$ ) was used. Provided that the use of $\mathrm{CaCl}_{2}$ shows the same behavior as $\mathrm{MgCl}_{2}$, the relatively low membrane charge and consequently similar swelling behavior as for glucose solutions without salt added, may explain the unchanged glucose retention when $\mathrm{CaCl}_{2}$ is added to the glucose solution and the relatively large change in glucose retention when $\mathrm{KCl}$ or $\mathrm{NaCl}$ are added to the glucose solution. 
Another hypothetical explanation is that the observed phenomenon is caused by the presence of a pore size distribution in the membrane. When salt is added to the feed, the flux of the membrane is reduced. The effect of the addition of $1.0 \mathrm{M} \mathrm{NaCl}$ on the reduction of the flux as compared to a situation where no $\mathrm{NaCl}$ is present in the feed is shown in Fig. 13 and 14 for NF with varying pore radius. One case (see Fig. 13) represents a situation where the membrane charge per volume $Q_{0}$ was assumed to be independent of the pore radius, whereas the other (more likely) case (see Fig. 14) assumes that the membrane charge per surface area of the pore $\left(Q_{a, 0}=r_{p}{ }^{*} Q_{0} / 2\right)$ is independent of the pore radius. As can be seen from Fig. 13 and 14, this flux decrease as a consequence of salt addition is relatively high for low pore radii. Consequently, the larger pores contribute more to the permeate flux when a feedstock containing salt is used. Since these larger pores have lower glucose retention than the smaller pores (see Fig.13 and 14), reduced glucose retention is possible and consequently a shift in the apparent pore radius to higher values may result. A similar effect of the pore size distribution on retention has been reported by Bowen and Welfoot [26].

Regardless of the possible explanation, the observed effect of salts on the retention of uncharged solutes can be of great importance for several industrial applications, e.g. the desalination of carboxymethylinulin [27]. When the effect of salt on the retention of uncharged product components during desalting using a nanofiltration membrane is not taken into account properly in the selection of the membrane, higher than anticipated product losses and permeate discharge costs may be encountered. Therefore, for industrial application studies the effect of salt on the retention of neutral components has to be incorporated in the model predictions or application tests with the industrial feed, under conditions where only interpolation of the results is required to predict commercial operation, should be carried out. 


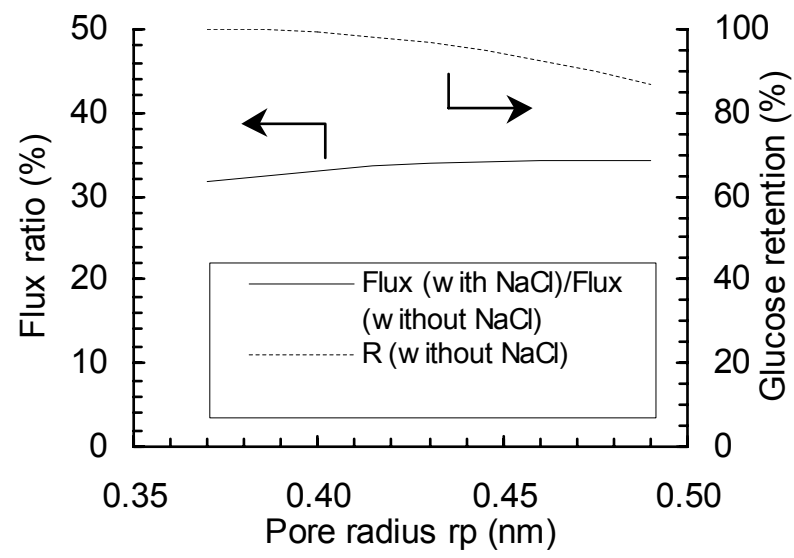

Figure 13: The calculated effect of the pore radius on the flux ratio (the flux in the presence of $1.0 \mathrm{M} \mathrm{NaCl}$ over the flux without the presence of $\mathrm{NaCl}$ ) and glucose retention (without $\mathrm{NaCl}$ ) for $\mathrm{NF}$ at $\mathrm{P}=30$ bar using a $0.15 \%$ glucose solution, assuming $Q_{0}$ to be independent of the pore size.

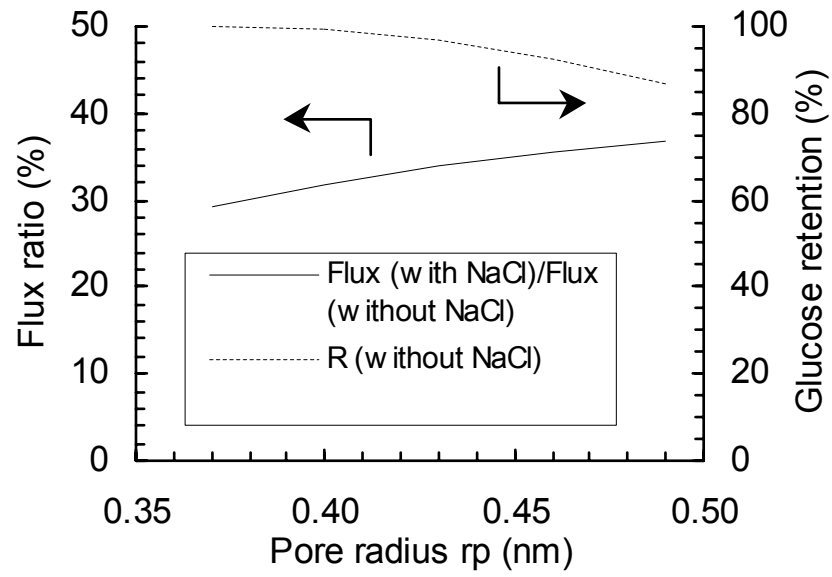

Figure 14: The calculated effect of the pore radius on the flux ratio (the flux in the presence of $1.0 \mathrm{M} \mathrm{NaCl}$ over the flux without the presence of $\mathrm{NaCl}$ ) and glucose retention (without $\mathrm{NaCl}$ ) for $\mathrm{NF}$ at $\mathrm{P}=30$ bar using a $0.15 \%$ glucose solution, assuming $Q_{a, 0}$ to be independent of the pore size. 


\section{Conclusions}

For nanofiltration membranes the addition of salt ions to a glucose solution can result in reduction of the glucose retention. This reduction is membrane specific and furthermore depends on the retention of the salt ion added. A low salt ion retention results in a higher decrease in glucose retention. For addition of $\mathrm{NaCl}, \mathrm{CaCl}_{2}$, and $\mathrm{KCl}$, the retention drop is a function of the $\mathrm{Cl}^{-}$concentration in the permeate for Desal 5DK and NF. This function is independent of the cation used. The observed effect is important for prediction of membrane performance during the demineralization of sugar solutions. However, it is not well described by a predictive model on the basis of the MaxwellStefan equation, which uses only pore size exclusion, Donnan exclusion, and average pore size to describe the separation process.

The reduced glucose retention in the presence of salt can be described well when the pore radius value substituted in the model is increased. Several hypotheses are available to explain the observed phenomenon. An example is that the glucose retention reduction is caused by an increased effective average pore size, as a consequence of higher repulsion forces between the double layers in the pores when the concentration of ions and therefore the membrane charge, as is predicted by the model, is increased. Another possible explanation is the presence of a pore size distribution. The Maxwell-Stefan model shows that the addition of salt with relatively low retention reduces the flux of the small pores to a higher extent than the larger pores. Thus the retention of glucose is determined to a larger extent by the larger pores and reduces when salt is added. This explains why in experiments where salts with low retention characteristics are present, the glucose retention drop is relatively large and a larger pore size estimate in the Maxwell-Stefan model is required to predict the glucose retention more accurately.

\section{Nomenclature}

$\begin{array}{lll}D_{\infty} & \text { Diffusion coefficient } & \mathrm{m}^{2} \mathrm{~s}^{-1} \\ d_{m} & \text { Thickness of the membrane layer } & \mathrm{m} \\ F & \text { Faraday constant } & \mathrm{C} \mathrm{mol}^{-1} \\ J & \text { Permeate flux } & \mathrm{kg} \mathrm{m}^{-2} \mathrm{~h}^{-1}\end{array}$




\begin{tabular}{|c|c|c|}
\hline$J_{w}$ & Pure water permeate flux & $\mathrm{kg} \mathrm{m}^{-2} \mathrm{~h}^{-1}$ \\
\hline k & Mass transfer coefficient & $\mathrm{m} \mathrm{s}^{-1}$ \\
\hline$K_{s}$ & Model constant Freundlich equation & - \\
\hline$L$ & Length & $\mathrm{m}$ \\
\hline$P$ & Pressure & $\mathrm{Pa}$ \\
\hline$Q_{0}$ & Model constant Freundlich equation & $\mathrm{mol} \mathrm{m}^{-3}$ \\
\hline$Q_{a, 0}$ & $\begin{array}{l}\text { Membrane charge constant based on pore surface } \\
\text { area }\end{array}$ & $\mathrm{mol} \mathrm{m}^{-2}$ \\
\hline$Q_{m}$ & $\begin{array}{l}\text { Membrane charge concentration based on pore } \\
\text { volume }\end{array}$ & $\mathrm{mol} \mathrm{m}^{-3}$ \\
\hline$r_{s}$ & Stokes radius of ions and solutes & $\mathrm{m}$ \\
\hline$R$ & Rejection & $\%$ \\
\hline $\operatorname{Re}$ & Reynolds number & - \\
\hline Sc & Schmidt number & - \\
\hline$S h$ & Sherwood number & - \\
\hline$u$ & Diffusive velocity & $\mathrm{m} \mathrm{s}^{-1}$ \\
\hline$V_{m}$ & Molar volume & $\mathrm{m}^{3} \mathrm{~mol}^{-1}$ \\
\hline$x$ & Mole fraction & - \\
\hline$y$ & Co-ordinate in the membrane & M \\
\hline$z$ & Ion valence & - \\
\hline \multicolumn{3}{|c|}{ Greek } \\
\hline$\delta_{l}$ & Thickness concentration polarization layer & $\mathrm{m}$ \\
\hline$\delta_{m}$ & Effective membrane thickness & $\mathrm{m}$ \\
\hline$\varepsilon$ & Membrane porosity & - \\
\hline$\Phi$ & Electrical potential & $\mathrm{J} \mathrm{C}^{-1}$ \\
\hline$\mu$ & Chemical potential & $\mathrm{J} \mathrm{mol}^{-1}$ \\
\hline$T$ & Membrane tortuosity & - \\
\hline$\zeta$ & Diffusive friction coefficient & $\mathrm{kg} \mathrm{s}^{-1} \mathrm{~mol}^{-}$ \\
\hline
\end{tabular}

\section{Subscripts}

$\begin{array}{ll}i & \text { i-th component } \\ j & \text { j-th component }\end{array}$




\section{References}

[1] G. Bargeman, M. Timmer, C. van der Horst, Nanofiltration in the food industry, Chapter 12 in Nanofiltration - Principles and Applications $1^{\text {st }}$ edition, Eds. A.I. Schaefer, A.G. Fane and T. D. Waite, (2005), 305-328, Elsevier Advanced Technologies, Oxford, UK.

[2] W.R. Bowen, A.W. Mohammad, N. Hilal, Characterization of nanofiltration membranes for predictive purposes — use of salts, uncharged solutes and atomic force microscopy, J. Membr. Sci. 126 (1997) 91.

[3] J. Schaep, C. Vandecasteele, A.W. Mohammad, W.R. Bowen, Modelling the retention of ionic components for different nanofiltration membranes, Separ. Purif. Technol. 22-23 (2001) 169.

[4] G. Hagmeyer, R. Gimbel, Modelling the salt rejection of nanofiltration membranes for ternary ion mixtures and for single salts at different $\mathrm{pH}$ values, Desalination 117 (1998) 247.

[5] W.R. Bowen, H. Mukhtar, Characterization and prediction of separation performance of nanofiltration membranes, J. Membr. Sci. 112 (1996) 263.

[6] Y. Garba, S. Taha, N. Gondrexon, G. Dorange, lon transport modelling through nanofiltration membranes, J. Membr. Sci. 160 (1999) 187.

[7] H.C. van der Horst, J.M.K. Timmer, T. Robbertsen, J. Leenders, Use of nanofiltration for concentration and demineralization in the dairy industry: Model for mass transport, J. Membr. Sci. 104 (1995) 205.

[8] J. Straatsma, G. Bargeman, H.C. van der Horst, J.A. Wesselingh, Can nanofiltration be fully predicted by a model?, J. Membr. Sci. 198 (2002) 273.

[9] T.R. Noordman, P. Vonk, V.H.J.T. Damen, R. Brul, S.H. Schaafsma, M. de Haas, J.A. Wesselingh, Rejection of phosphates by a $\mathrm{ZrO}_{2}$ ultrafiltration membrane, J. Membr. Sci., 135 (1997) 203.

[10] T.R. Noordman, High flux membrane filtration, PhD thesis, University of Groningen, 1994.

[11] A.E. Yaroshchuk, Dielectric exclusion of ions from membranes, Adv. Coll. Interface Sci. 85 (2000) 193.

[12] A.E. Yaroshchuk, V. Ribitsch, The use of trace ions for advanced characterization of transport properties of NF membranes in electrolyte solutions: theoretical analysis, J. Membr. Sci. 201 (2002) 85.

[13] E.A. Mason, H.K. Lonsdale, Statistical-mechanical theory of membrane transport, J. Membr. Sci. 51 (1990) 1. 
[14] J.A. Wesselingh, R. Krishna, Mass transfer, Ellis Horwood Limited, 1990.

[15] J.A. Wesselingh, P. Vonk, G. Kraaijeveld, Exploring the Maxwell-Stefan description of ion exchange, The Chemical Engineering Journal, 57 (1995) 75.

[16] J.A. Wesselingh, A.M. Bollen, Multicomponent diffusivities from the free volume theory, Trans IChemE, 75A (1997) 590.

[17] P. Vonk, Diffusion of large molecules in porous structures $\mathrm{PhD}$ Thesis, University of Groningen, Groningen, The Netherlands, 1994.

[18] R.B. Bird, W.E. Stewart, E.N. Lightfoot, Transport Phenomena, Wiley, New York, 1960.

[19] V. Gekas, B. Hallström, Mass transfer in the membrane concentration polarisation layer under turbulent cross flow. Part 1. Critical literature review and adaptation of existing Sherwood correlations to membrane operations, J. Membr. Sci. 30 (1987) 153.

[20] W.R. Bowen, A.W. Mohammad, Characterization and prediction of nanofiltration membrane performance-a general assessment, Trans IChemE, 76 A (1998) 885.

[21] J. Schaep, C VandeCasteele, A.W. Mohammad, W.R. Bowen, Analysis of the salt retention of nanofiltration membranes using the Donnan-steric partitioning pore model, Sep. Sci. Techn. 34 (1999) 3009.

[22] J.M.K. Timmer, M.P.J. Speelmans, F. Donkers, H.C. van der Horst, Mass transfer of amino acids through nanofiltration membranes, in A.J.B. Kemperman and G.H. Koops (Eds.), Progress in Membrane Science and Technology, Book of Abstracts, Euromembrane '97, Enschede, The Netherlands, 22-27 June 1997, Dinkeldruk Oldenzaal, The Netherlands, 459.

[23] J.M.K. Timmer, Properties of nanofiltration membranes; model development and industrial application, PhD thesis, Technical University of Eindhoven, Eindhoven, the Netherlands, 2001.

[24] X.-L. Wang, T. Tsuru, M. Togoh, S.-I. Nakao, S. Kimura, Evaluation of pore structure and electrical properties of nanofiltration membranes, J. Chem. Eng. Japan 28 (1995) 186.

[25] E. Vellenga, G. Trägårdh, Nanofiltration of combined salt and sugar solutions: coupling between retentions, Desalination 120 (1998) 211.

[26] W.R. Bowen, J.S. Welfoot, Modelling of membrane nanofiltration - pore size distribution effects, Chem. Eng. Sci. 57 (2002) 1393. 
[27] J. Houwing, R. Jonker, G. Bargeman, J.G. van Doorn, M.A. Jansens, M.P.J. Dohmen-Speelmans, H.C. van der Horst, Ontzouten en concentreren van carboxymethylinuline (CMI) met nanofiltratie, Procestechnologie, 3 (2001) 23. 


\section{Chapter 3}

The effect of $\mathrm{NaCl}$ and glucose concentration on retentions for nanofiltration membranes processing concentrated

solutions

This chapter has been published as:

G. Bargeman, J.B. Westerink, O. Guerra-Miguez, M. Wessling, The effect of $\mathrm{NaCl}$ and glucose concentration on retentions for nanofiltration membranes processing concentrated solutions, Sep. Pur. Techn. 134 (2014), 46-57. 


\begin{abstract}
Most nanofiltration studies deal with solutions containing less than $60 \mathrm{~g} \cdot \mathrm{L}^{-1}$ salts and low sugar concentrations. For concentrated solutions limited information is available about interactions between neutral and charged solutes during nanofiltration, and their effect on flux and retention. This study reports results for nanofiltration of solutions containing $\mathrm{NaCl}$ in concentrations between $1 \mathrm{~g} \cdot \mathrm{L}^{-1}$ and $300 \mathrm{~g} \cdot \mathrm{L}^{-1}$ and glucose concentrations as high as $80 \mathrm{~g} \cdot \mathrm{L}^{-1}$. Five membranes were characterized and evaluated. For mixed glucose $/ \mathrm{NaCl}$ solutions with $\mathrm{NaCl}$ concentrations higher than $90 \mathrm{~g} \cdot \mathrm{L}^{-1}$, a glucose concentration increase from $1 \mathrm{~g} \cdot \mathrm{L}^{-1}$ to $80 \mathrm{~g} \cdot \mathrm{L}^{-1}$ only affected glucose retention at the same flux for NTR 7450 . For the tightest membranes slightly negative $\mathrm{NaCl}$ retentions were obtained for high glucose concentrations in the feed. Glucose retention for solutions containing $1 \mathrm{~g} \cdot \mathrm{L}^{-1}$ glucose decreased strongly when the $\mathrm{NaCl}$ concentration was increased from $0 \mathrm{~g} \cdot \mathrm{L}^{-1}$ to $100 \mathrm{~g} \cdot \mathrm{L}^{-1}$. The observed glucose retention reductions were not caused by flux changes. A change in the ratio of glucose radius over membrane effective pore radius could explain the obtained results. Determined pore radii and effective thickness can be used for development of nanofiltration applications for desalination of concentrated glucose solutions.
\end{abstract}




\section{Introduction}

Nanofiltration membranes are a class of membranes, with properties in between those of ultrafiltration (UF) and reverse osmosis (RO) membranes. The development of new nanofiltration processes is facilitated by the availability of fundamental mathematical models, such as extended Nernst-Planck and Maxwell-Stefan models [1-9]. In these models generally steric hindrance, Donnan exclusion [1, 2], dielectric exclusion [3, 10] and/or the solvation energy are assumed to be responsible for the retention of solutes by nanofiltration membranes [11]. The extended Nernst-Planck model, which is more often used in publications related to membrane modeling, actually is a simplification of the Maxwell-Stefan model.

In both the Maxwell-Stefan and the extended Nernst-Planck model, the mean pore radius, the effective membrane thickness, and the surface charge density [1, 3, 4] are the parameters required to describe retention behavior on the basis of the sieving effect and Donnan exclusion during transport. These parameters are usually obtained by fitting the model to solute retentions and membrane fluxes measured in membrane characterization experiments using pure water, single salt and single sugar solutions [7]. Usually, the membrane performance for processing a solution containing a mixture of salts can be fitted well. However, generally the results cannot be predicted on the basis of the parameters obtained in membrane characterization experiments with single component solutions [7]. The same applies for mixtures containing neutral components and salts, or combinations of neutral organic molecules with different molecular weight [12]. Clearly, the interactions between different components and the membrane, and their effect on the separation characteristics of nanofiltration membranes, are not yet sufficiently well understood and fitting of the mean pore radius, the effective membrane thickness and the surface charge density for individual membrane processing the solution of interest is still required for the development of industrial applications.

Previous studies studying the interactions between neutral and/or charged components [12-21], some of them even including $\mathrm{pH}$ and temperature effects [16], and their effect on retentions are based on nanofiltration of solutions with relatively low concentrations of the charged solutes and neutral solutes. In these studies clear effects of changes in salt concentrations on glucose retention, which reduced when the salt concentration increased, have been reported by several authors e.g. [12, 13]. Several explanations have been proposed for these effects. These explanations include a change in effective 
pore radius of the membrane as a consequence of membrane swelling or a flux change in combination with the presence of a pore size distribution as e.g. proposed in [12] and a change in effective molecular size of the neutral component as a consequence of the presence of salt as e.g. proposed in [13]. Recently, it has been shown that both of the mechanisms can contribute to the reduction of the retention of neutral components as a consequence of the addition of salt [22, 23].

Even though a lot of knowledge has been obtained in the recent years on the effects of salts on the retention of neutral components during nanofiltration, the knowledge for processing of feeds with high solute concentrations is still limited. This hampers the development of nanofiltration application for these concentrated feed streams. Only recently Luo and Wan [24] have presented interesting results from nanofiltration experiments with solutions containing glucose at low concentrations and $\mathrm{NaCl}$ concentrations up to $175 \mathrm{~g} \cdot \mathrm{L}^{-1}$. Earlier, Sjoman et al. [25] have presented results for the separation of two neutral components, xylose and glucose, from concentrated monosaccharide solutions and Bargeman et al. [26] have presented results for nanofiltration of solutions saturated in both, $\mathrm{NaCl}$ and $\mathrm{Na}_{2} \mathrm{SO}_{4}$, showing the effects of high $\mathrm{Na}_{2} \mathrm{SO}_{4}$ concentrations on $\mathrm{NaCl}$ retention.

The objective of this study is to evaluate whether effects observed during nanofiltration of solutions with very high $\mathrm{NaCl}$ (up to almost saturated solutions) and glucose concentrations (up to $80 \mathrm{~g} \cdot \mathrm{L}^{-1}$ ) are similar to those found for nanofiltration of solutions containing relatively low $\mathrm{NaCl}$ and glucose concentrations. Studying the effects of other salts and neutral molecules at high concentrations during nanofiltration could further improve insights, but this is outside of the scope of the current study. First indications on the behavior of different salts and neutral components at high concentrations can be obtained by combining the results of this work with earlier publications describing nanofiltration at lower concentrations. The effect of different salts at lower concentrations on glucose retention has been studied in Bargeman et al. [12]. Additionally, the effect of several salts on PEG retention at lower concentrations has been reported by Bouranene et al. [17]. Furthermore, it is the objective of this study to determine values for the mean pore diameter and the effective membrane thickness for several commercially available nanofiltration membranes during processing of the concentrated solutions. The availability of these parameters will facilitate the development of nanofiltration applications in industry. Examples of such applications 
are the use of nanofiltration for separation of sodium sulfate from sodium chloride in the Chlor/Alkali industry [27] and in the sugar industry [28]. Thus, the operating window for nanofiltration is extended to practically saturated feeds, knowledge about the performance of more nanofiltration membranes becomes publically available, especially for processing of concentrated feeds, and fundamental understanding of nanofiltration processes is extended to processing of feeds with high solute concentrations.

\section{Theoretical background}

The extended Nernst-Planck description is most often used to interpret the flux and retention results obtained from nanofiltration experiments. Therefore we have used this description in this study as well. The mean pore radius and effective thickness reported in this study were obtained using the equations described in [1, 2].

For uncharged solutes like glucose, the transport through the membrane is governed purely by diffusive and convective flows. Consequently, the Nernst-Planck equation yields:

$j_{i}=-D_{i, p} \frac{d c_{i}}{d x}+K_{i, c} c_{i} v$

where

$D_{i, p}=K_{i, d} D_{i, \infty}$

$K_{i, d}$ and $K_{i, c}$, account for the hindrance due to diffusion and convection respectively and can be related to the hydrodynamic coefficients $K^{-1}$ (enhanced drag) and $G$ (lag coefficient) according to the following equations [1]:

$$
\begin{aligned}
& K^{-1}(\lambda, 0)=1.0-2.3 \lambda+1.154 \lambda^{2}+0.224 \lambda^{3} \\
& G(\lambda, 0)=1.0+0.054 \lambda-0.988 \lambda^{2}+0.441 \lambda^{3}
\end{aligned}
$$

where

$$
\lambda=\frac{r_{s}}{r_{p}}
$$

In equation (5) $r_{s}$ represents the solute radius and $r_{p}$ the mean pore radius of the membrane. 
In our approach it is assumed that the solute velocity was fully developed [1] and the solute velocity had a parabolic profile of the Hagen-Poiseuille type. Thus the hindrance factors become [1]:

$$
\begin{aligned}
& K_{i, d}=K^{-1}(\lambda, 0) \\
& K_{i, c}=(2-\Phi) G(\lambda, 0)
\end{aligned}
$$

where

$$
\Phi=(1-\lambda)^{2}
$$

Equation (1) can be expressed in terms of real rejection of the solute by the membrane as:

$$
R_{\text {real }}=\frac{C_{i, m}-C_{i, p}}{C_{i, m}}=1-\frac{K_{i, c} \Phi}{1-\exp \left(-P e_{m}\right)\left[1-\Phi K_{i, c}\right]}
$$

where the Peclet number $P e_{m}$ is defined as:

$$
P e_{m}=\frac{K_{i, c} J}{K_{i, d} D_{i, \infty}} \frac{\Delta x}{A_{k}}
$$

where $J$ is the permeate flux in $\left(\mathrm{m}^{3} \mathrm{~m}^{-2} \mathrm{~s}^{-1}\right), D_{i, \infty}$ is the bulk diffusivity in $\left(\mathrm{m}^{2} \mathrm{~s}^{-1}\right)$ and $\Delta x / A_{k}$ is the effective membrane thickness $(m)$.

Concentration polarization at the membrane surface was taken into account as well. The relation between the real retention and the observed retention can be obtained from $[1,2]$ :

$$
\ln \left(\frac{1-R_{\text {obs }}}{R_{\text {obs }}}\right)=\ln \left(\frac{1-R_{\text {real }}}{R_{\text {real }}}\right)+\frac{J}{k}
$$

Since cross-flow operation was used in this study, the correlation for the mass transfer coefficient $k$ as proposed in [1] for dead end stirred cell operation could not be used. Consequently, we assumed the mass transfer coefficient $k$ to be equal to the ratio of the diffusion coefficient at infinite dilution $D_{\infty}$ over the film thickness $\delta$. On the basis of earlier studies in the DSS labstak at similar flow-rate [12] a constant value for the film thickness of $\delta=2.0 * 10^{-5} \mathrm{~m}$ has been selected. 
Furthermore, in the approach described in [1, 2], the effective membrane thickness $\Delta x / A_{k}$ was obtained from the Hagen-Poiseuille equation using the pure water flux of the membrane:

$$
\frac{J_{w}}{\Delta P}=\frac{r_{p}{ }^{2}}{8 \mu\left(\Delta x / A_{k}\right)}
$$

where $J_{w} / \Delta P$ is the pure water permeance in $\left(\mathrm{m}^{-1} \mathrm{~s}^{-1} \cdot \mathrm{kPa}^{-1}\right)$ and $\mu$ is dynamic viscosity of the solution in (kPa.s).

This is a good approach for processing of solutions containing neutral solutes only. However, when the solution contains salts next to neutral solutes such as glucose, the mean pore radius and effective thickness of the membrane depend on the composition of the solution [12] and is different from values obtained for pure water. Consequently, the product flux $(J)$ and the viscosity of the solution treated has to be used in the Hagen-Poiseille equation. Furthermore, the osmotic pressure difference between the concentrate and permeate for highly concentrated solutions affects the driving force for the flow through the membrane and needs to be taken into account as well. Instead of equation (12) the following equation therefore has been used to calculate the effective membrane thickness $\Delta \mathrm{x} / \mathrm{A}_{\mathrm{k}}$ :

$$
\frac{J}{(\Delta P-\Delta \pi)}=\frac{r_{p}{ }^{2}}{8 \mu\left(\Delta x / A_{k}\right)}
$$

The osmotic pressure difference $\Delta \pi$ for the different nanofiltration membranes and for processing of the different solutions can be obtained from equation (13) by determining the flux at different trans-membrane pressures $\Delta P$.

\section{Experimental}

\subsection{Membranes}

Retention experiments were carried out with five different commercially available nanofiltration membranes (Desal 5DK, Desal 5HL, NP030, NTR 7450 and NF270). Desal 5DK and Desal 5HL (GE Water Technologies) are thin film composite (TFC) semi-permeable membranes with a polyamide top layer. NP030 (NADIR) is a permanently hydrophilic poly-ether sulfone membrane. NTR 7450 (SOMICON, Nitto 
Denko) is a synthetic polymer composite membrane. NF 270 (Dow) is a polyamide based TFC membrane. Further information about these membranes, as reported by their suppliers, is listed in Table 1.

Table 1: $\quad$ Molecular weight cut-off (MWCO), pure water permeance and $\mathrm{Na}_{2} \mathrm{SO}_{4}$, $\mathrm{MgSO}_{4}$ and $\mathrm{NaCl}$ retentions of nanofiltration membranes as reported by suppliers.

\begin{tabular}{|c|c|c|c|c|c|c|}
\hline Membrane & $\begin{array}{c}\text { (Pure) water } \\
\text { permeance } \\
\left(\mathrm{L} \cdot \mathrm{m}^{-2} \cdot \mathrm{h}^{-1} \cdot \text { bar }^{-1}\right)\end{array}$ & $\begin{array}{c}\mathrm{MgSO}_{4} \\
\text { retention } \\
(\%)\end{array}$ & $\begin{array}{c}\mathrm{Na}_{2} \mathrm{SO}_{4} \\
\text { retention } \\
(\%)\end{array}$ & $\begin{array}{c}\mathrm{NaCl} \\
\text { retention } \\
(\%)\end{array}$ & $\begin{array}{c}\mathrm{CaCl}_{2} \\
\text { retention } \\
(\%)\end{array}$ & $\begin{array}{c}\text { MWCO } \\
\text { (Da) }\end{array}$ \\
\hline Desal 5DK ${ }^{(1)}$ & 5.4 & 98 & & & & 200 \\
\hline Desal $5 \mathrm{HL}^{(1)}$ & 7.2 & 98 & & & & $150-300$ \\
\hline NP $030^{(2)}$ & $>1$ & & $80-95$ & $25-35$ & & \\
\hline NTR $7450^{(3)}$ & 11 & & & 50 & & \\
\hline NF270 & $11^{(4)}-13^{(5)}$ & $>97^{(4)}$ & & & $40-60^{(5)}$ & \\
\hline
\end{tabular}

(1) Specifications are based on a $2,000 \mathrm{mg} \cdot \mathrm{L}^{-1} \mathrm{MgSO}_{4}$ solution at $100 \mathrm{psig}(6.9 \mathrm{bar}), 77^{\circ} \mathrm{F}$ $\left(25^{\circ} \mathrm{C}\right), 10 \%$ recovery, after 24 hours. Individual element flux may vary $\pm 20 \%$.

(2) Test conditions: 40 bar, $20{ }^{\circ} \mathrm{C}$, stirred cell $(700 \mathrm{rpm})$. Retention of $\mathrm{Na}_{2} \mathrm{SO}_{4}$ with solution of $\mathrm{Na}_{2} \mathrm{SO}_{4}(0.5 \%)$. Retention of $\mathrm{NaCl}$ with solution of $0.5 \% \mathrm{NaCl}$.

(3) Average flux: for a lot more than 50 elements. Test conditions for $\mathrm{NaCl}$ retention: $\mathrm{NaCl}$ 0.2 wt $\%$, at 10 bar, $25{ }^{\circ} \mathrm{C}$, and $20-35 \%$ recovery.

(4) Permeate flow and salt passage based on the following test conditions: $2000 \mathrm{mg} \cdot \mathrm{L}^{-1}$ $\mathrm{MgSO}_{4}, 70 \mathrm{psi}(4.8 \mathrm{bar}), 77^{\circ} \mathrm{F}\left(25^{\circ} \mathrm{C}\right)$, and $15 \%$ recovery.

(5) Permeate flow and salt passage based on the following test conditions: $500 \mathrm{mg} \cdot \mathrm{L}^{-1}$ $\mathrm{CaCl}_{2}, 70$ psi (4.8 bar), $77^{\circ} \mathrm{F}\left(25^{\circ} \mathrm{C}\right)$, and $15 \%$ recovery.

\subsection{Feed components}

Glucose and $\mathrm{NaCl}$ used during the experiments were analytical grade materials obtained from Fisher Emergo (The Netherlands) and Sigma Aldrich (The Netherlands), respectively. Some properties of these solutes are listed in Table 2. All feed batches used during the experimental program were prepared by dissolving these components in reverse osmosis permeate of tap water. 
Table 2: Diffusivities and Stokes radii of ion and neutral solute [12].

\begin{tabular}{lccc}
\hline Solute & $\begin{array}{c}\text { Ionic } \text { or molecular } \\
\text { weight } \\
\left(\mathrm{g} \mathrm{mol}^{-1}\right)\end{array}$ & $\begin{array}{c}\text { Diffusivity } \\
\mathrm{D} \infty\end{array}$ & $\begin{array}{c}\text { Solute radius } \\
\left(\mathrm{m}^{2} \mathrm{~s}^{-1}\right) \times 10^{-9}\end{array}$ \\
\hline $\mathrm{Na}^{+}$ & 23 & 1.33 & $\begin{array}{c}\mathrm{r}_{\mathrm{s}} \\
(\mathrm{nm})\end{array}$ \\
$\mathrm{Cl}^{-}$ & 35.5 & 2.03 & 0.161 \\
Glucose & 180 & 0.60 & 0.106 \\
\hline
\end{tabular}

\subsection{Experimental set-up}

Retention experiments were carried out using a DSS Labstak@ M20 unit as described by Van der Horst et al. [6]. The experiments were performed in batch circulation mode, recycling both the retentate and permeates to the feed tank. NP 030, Desal 5HL, NTR 7450, NF 270, and Desal 5DK, were placed in series from top to bottom in the module. Each membrane type had a surface area of $0.036 \mathrm{~m}^{2}$. In the DSS Labstak® M20 unit used, the liquid feed was supplied to the top of the membrane stack, flowing downwards to the outlet at the bottom of the stack. Pressure indicators were placed at the inlet (feed side) and the outlet (retentate side) of the Labstak ${ }^{\circledR}$ M20. Temperature was controlled in the feed vessel of the unit. A Hydracel pump was used to pump the feed from the feed vessel to the Labstak® M20. A Julabo cooling unit was used to control the temperature of the feed to the membrane unit. The cooling liquid was sent to a cooler installed in the feed vessel.

\subsection{Experimental conditions}

Prior to the experiments the membranes were pre-compacted by increasing the pressure to 25 bar and maintaining circulation operation at this pressure, for 1 hour. During the short pre-compaction procedure a temperature of $20^{\circ} \mathrm{C}$ and a cross-flow rate of 600-650 L.h ${ }^{-1}$ were used. This cross-flow rate results in a cross-flow velocity of 0.9$1.0 \mathrm{~m} . \mathrm{s}^{-1}$. Reverse osmosis permeate of tap water was used as feed.

The temperature and cross-flow rate during all further experiments were approximately $20^{\circ} \mathrm{C}$ and $600-650$ L. $^{-1}$, respectively. Since the combined permeate flow of the membranes was always less than $5 \%$ of the retentate flow, the cross-flow velocity was practically equal for all the membranes. The pressure-drop along the feed/retentate side 
of the module was 1 bar from top to bottom during all experimental conditions. This pressure drop was taken into account in the calculation of trans-membrane pressures for each individual membrane. The position of the membrane in the module therefore did not have a significant effect on the results obtained.

Pure water fluxes for determination of the pure water permeances of individual membranes were measured using RO permeate of tap water at pressures between 6 bar to 24 bar, going from low to high pressures. Subsequently, an experiment with a 1 g. $\mathrm{L}^{-1}$ sodium chloride solution at 10 bar pressure was performed. These experiments were done to characterize the membranes and to validate their performance against earlier reported results.

Retention experiments were carried out with pressures between 5 bar and 25 bar, increasing pressure in steps of 5 bar or 10 bar. After each pressure adjustment, at least 60 minutes were allowed for equilibrium to be reached. At each pressure, the temperature, the permeate flux, and the feed and permeates composition were determined. To investigate the influence of salt concentration on glucose retention and the effect of glucose concentration on $\mathrm{NaCl}$ retention, experiments were carried out using feeds containing $1 \mathrm{~g} \cdot \mathrm{L}^{-1}$ glucose in combination with a $\mathrm{NaCl}$ concentration of either approximately $100 \mathrm{~g} . \mathrm{L}^{-1}, 185 \mathrm{~g} . \mathrm{L}^{-1}$ or $275 \mathrm{~g} . \mathrm{L}^{-1}$, and feeds consisting of a single salt solution containing $100 \mathrm{~g} . \mathrm{L}^{-1}, 190 \mathrm{~g} \cdot \mathrm{L}^{-1}$ or $260 \mathrm{~g} \cdot \mathrm{L}^{-1} \mathrm{NaCl}$ without glucose. Furthermore, a series of experiments was performed using solutions of $80 \mathrm{~g} \cdot \mathrm{L}^{-1}$ glucose in combination with either $100 \mathrm{~g} . \mathrm{L}^{-1} \mathrm{NaCl}, 175 \mathrm{~g} . \mathrm{L}^{-1} \mathrm{NaCl}$ or $260 \mathrm{~g} \cdot \mathrm{L}^{-1} \mathrm{NaCl}$.

\subsection{Analyses}

Glucose concentrations were analyzed by HPLC, using two different columns. The glucose analyses were done in several series. The characteristics of both columns are summarized in Table 3.

For analysis performed using column 1 (see Table 3), samples containing both glucose and $\mathrm{NaCl}$ samples were diluted, extracted with a silver ion solution containing cartridge and subsequently filtered to remove remaining $\mathrm{AgCl}$ from the sample, to avoid disturbance of the glucose analysis due to the presence of $\mathrm{NaCl}$. For column number 2, only dilution of the samples was required. Several samples were analyzed using both columns. Both columns showed the same analytical results. The $\mathrm{NaCl}$ concentrations 
were analyzed by titration by a Metrohm titroprocessor and conductivity measurements with a WTW conductometer. The $\mathrm{NaCl}$ analyses obtained from the titration procedure are based on the calculation of the quantity of $\mathrm{NaCl}$ by means of addition of $\mathrm{AgNO}_{3}$ to the sample. The density for all samples was measured by weighing a known volume of sample.

Table 3: Characteristics of the HPLC columns used.

\begin{tabular}{lcc}
\hline & Column 1 & Column 2 \\
\hline Column & Alltech IOA-1000 Organic Acids & Ubondapak $\mathrm{NH}_{2}$ \\
Temperature $\left({ }^{\circ} \mathrm{C}\right)$ & 40 & 30 \\
Mobile phase & $0.01 \mathrm{~N} \mathrm{H}_{2} \mathrm{SO}_{4}$ & $\mathrm{H}_{2} \mathrm{O} / \mathrm{CAN} 25 / 75$ \\
Injection Volumes $(\mu \mathrm{L})$ & 20 & 20 \\
Detection & $\mathrm{RI}$ & $\mathrm{RI}$ \\
Time of run $(\mathrm{min})$ & 43 & 12 \\
Flow $\left(\mathrm{ml} \cdot \mathrm{min}^{-1}\right)$ & 0.5 & 1 \\
\hline
\end{tabular}

\section{Results and Discussion}

\subsection{Pure water permeances}

The pure water permeances, determined on the basis of pure water flux measurements, have been determined to check whether the membranes samples used were representative samples. Results are shown in Table 4, where measured values are compared with permeance ranges reported in open literature. For all membranes evaluated in this study measured values fall within the range reported in open literature. Only for Desal $5 \mathrm{HL}$ a slightly higher value is obtained than reported in other literature sources so far. For NP030 a comparison with its predecessor N30F is made, since permeance data for NP030 could not be found. On the basis of the results NP030 appears to be superior to its predecessor. Despite these small differences, the membrane samples used in our study are considered to be sufficiently representative for the purpose of this study. 
Table 4: $\quad$ Pure water permeance of nanofiltration membranes at room temperature as reported in open literature.

\begin{tabular}{|c|c|c|c|}
\hline Membrane & $\begin{array}{c}\text { Measured pure water } \\
\text { permeance } \\
\left(\mathrm{L} \cdot \mathrm{m}^{-2} \cdot \mathrm{h}^{-1} \cdot \mathrm{bar}^{-1}\right)\end{array}$ & $\begin{array}{c}\text { Literature pure water } \\
\text { permeance range } \\
\left(\mathrm{L} \cdot \mathrm{m}^{-2} \cdot \mathrm{h}^{-1} \cdot \mathrm{bar}^{-1}\right)\end{array}$ & References \\
\hline Desal 5DK & 4.5 & $3.1-7.9$ & {$[3,7,12,13,31-38]$} \\
\hline Desal 5HL & 11.6 & $4.3-9.0$ & {$[35,37,47]$} \\
\hline N $30 \mathrm{~F}$ & 4.4 & $2.9-3.8$ & {$[39,51]$} \\
\hline NTR 7450 & 6.3 & $5.8-23$ & {$[12,34,39-41,48]$} \\
\hline NF270 & 13.5 & $8.6-16$ & {$[31,37,42-46]$} \\
\hline
\end{tabular}

4.2. Fluxes and retentions using a $1 \mathrm{~g} \cdot \mathrm{L}^{-1} \mathrm{NaCl}$ solution at 10 bar trans-membrane pressure

The $\mathrm{NaCl}$ retentions determined for Desal 5DK, Desal 5HL, NTR 7450 and NF 270 during processing of a $1 \mathrm{~g} \cdot \mathrm{L}^{-1} \mathrm{NaCl}$ solution at a trans-membrane pressure of 10 bar are significantly higher than that for NP 030 (see Fig. 1). It should be noted that for Desal $5 \mathrm{DK}$ the flux at 10 bar pressure processing the $1 \mathrm{~g} \cdot \mathrm{L}^{-1} \mathrm{NaCl}$ solution was slightly higher than the pure water flux at the same condition. A permeance increase, as observed in this study for Desal $5 D K$, is reported more often for nanofiltration membranes. For NFT50 Nilsson et al. [29] showed that the permeance of this membrane increased after introduction of a solution containing $\mathrm{NaCl}$. For Desal 5DL (a membrane type quite similar to Desal 5DK) higher membrane permeance was obtained after the pressure was increased to 25 bar as reported by Mänttäri et al. [30]. Since for Desal 5DK in the current study nanofiltration of the $\mathrm{NaCl}$ solution was performed immediately after the determination of the clean water flux at 25 bar and the clean water flux was determined by gradually increasing pressure, the higher flux for Desal 5DK during processing of the $\mathrm{NaCl}$ solution can therefore also be due to the fact that just prior to processing of this solution operation at 25 bar had occurred. Alternatively, first time operation with the $\mathrm{NaCl}$ solution immediately after processing of pure water could have led to the observed higher flux (similar to the effect of $\mathrm{NaCl}$ on the performance of NFT-50 as reported by Nilsson et al. [29]). 
The $\mathrm{NaCl}$ retention found for Desal 5DK at 10 bar trans-membrane pressure and room temperature is in between retentions reported by Bowen and Welfoot [49] and Hagmeyer and Gimbel [3]. The NaCl retention for NTR 7450 seems to be reasonably well in line with results reported by Schaep et al. [41, 50], despite the significant difference found in flux between the NTR 7450 samples evaluated by Schaep et al. and in this study. The $\mathrm{NaCl}$ retention obtained in this study for $\mathrm{NF} 270$ is similar to that reported by Boussu et al. [44]. Tang et al. [45] reported a slightly lower $\mathrm{NaCl}$ retention for NF 270, possibly as a consequence of the relatively low cross-flow velocity used during their test. For NP030 the $\mathrm{NaCl}$ retention was similar to the retention found for N30F (the predecessor of NP030) [51]. The characterization results using the $1 \mathrm{~g} \cdot \mathrm{L}^{-1}$ $\mathrm{NaCl}$ solution confirm the earlier conclusion that the membrane samples used are sufficiently representative for the purpose of this study.

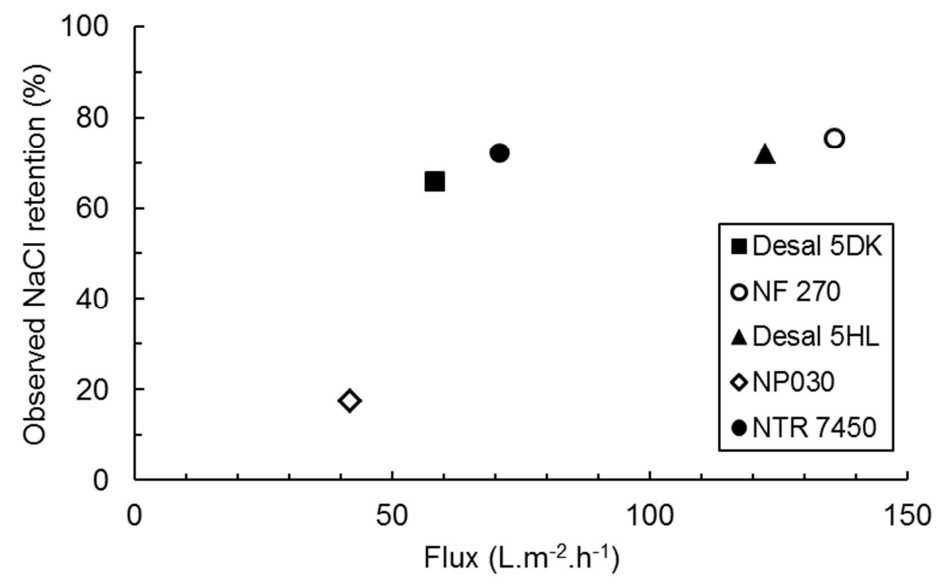

Figure 1: Observed $\mathrm{NaCl}$ retention and flux for NP 030, Desal 5HL, NTR 7450, NF 270 and Desal $5 \mathrm{DK}$ processing a $1 \mathrm{~g}^{-\mathrm{L}^{-1}} \mathrm{NaCl}$ solution at a transmembrane pressure of 10 bar and $20^{\circ} \mathrm{C}$.

\subsection{Membrane characterization using a 1 g. $L^{-1}$ glucose solution}

The glucose retentions obtained for Desal 5DK, Desal $5 \mathrm{HL}$ and NF 270 during processing of a $1 \mathrm{~g} . \mathrm{L}^{-1}$ glucose solution are significantly higher than those for NTR 7450 and NP 030. At a flux of $50 \mathrm{~L} . \mathrm{m}^{-2} \cdot \mathrm{h}^{-1}$ glucose retentions of $93 \%, 96 \%, 97 \%, 67 \%$ and $42 \%$ have been obtained for Desal 5HL, Desal 5DK, NF 270, NP 030 and NTR 7450, 
respectively (see Fig. 2). From this flux value on the glucose retention for Desal 5DK, Desal 5HL, NF 270 and NTR 7450 started to decrease with increasing flux. This indicates that concentration polarization clearly affected the glucose retention at these high fluxes, which is observed more frequently. For NP 030 and NTR 7450 at flux values below $30 \mathrm{~L} \cdot \mathrm{m}^{-2} \cdot \mathrm{h}^{-1}$ the glucose retention was found to increase for an increasing flux.

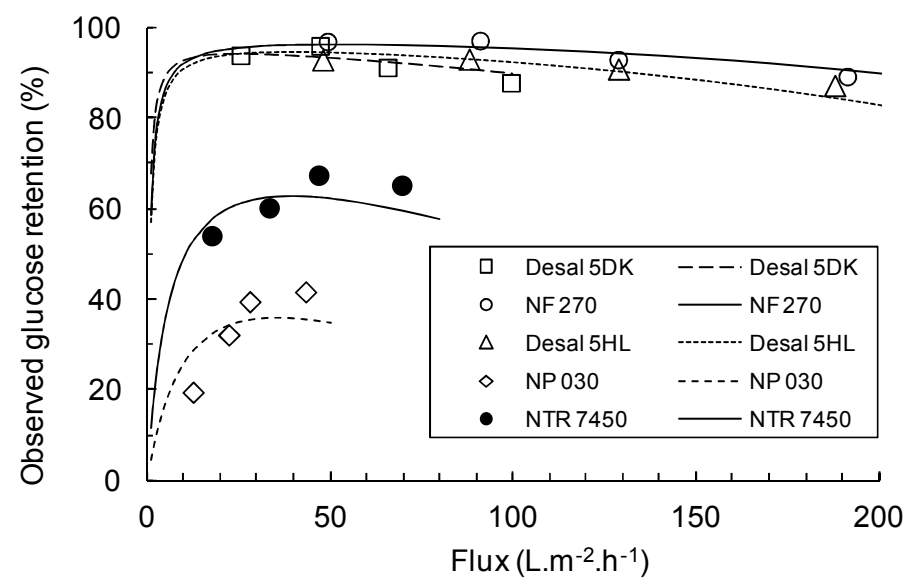

Figure 2: Observed glucose retention as function of flux for NP 030, Desal 5DK, Desal 5HL, NTR 7450 and NF 270 during processing of a 1 g. $\mathrm{L}^{-1}$ glucose solution at room temperature and operating pressures of 5 bar, 10 bar, 20 bar and 30 bar (symbols are measured values and lines are calculated values based on pore radius and effective thickness reported in Table 5).

The mean pore radius $\left(r_{p}\right)$ and the effective thickness $\left(\Delta x / A_{k}\right)$ of the individual membranes, based on the permeance and the maximum glucose retention, obtained for the individual membranes during processing of the $1 \mathrm{~g} \cdot \mathrm{L}^{-1}$ glucose solution, have been listed in Table 5. The approximate characterization method as proposed in [1, 41], taking into account concentration polarization, has been used, as mentioned and described in earlier in section 2 . In the calculation a diffusion coefficient at infinite solution for glucose of $D_{\infty}=0.60^{*} 10^{-9} \mathrm{~m}^{2} . \mathrm{s}^{-1}$ and a glucose radius of $r_{\mathrm{s}}=0.36 \mathrm{~nm}$ have been assumed [12]. The determination of the effective thickness of the membranes, using the Hagen-Poiseuille equation, has been based on obtained fluxes for the $1 \mathrm{~g} \cdot \mathrm{L}^{-1}$ glucose feed solution. 
Table 5: Estimated pore radii and effective thicknesses $\left(\Delta x / A_{k}\right)$ for NP030, Desal 5DK, Desal 5HL, NTR 7450 and NF270.

\begin{tabular}{lcc}
\hline Membrane type & $\begin{array}{c}\mathrm{r}_{\mathrm{p}} \\
(\mathrm{nm})\end{array}$ & $\begin{array}{c}\Delta \mathrm{x} / \mathrm{A}_{\mathrm{k}} \\
(\mu \mathrm{m})\end{array}$ \\
\hline NP030 & 0.90 & 23 \\
Desal 5HL & 0.43 & 1.2 \\
NTR 7450 & 0.62 & 6.6 \\
NF 270 & 0.41 & 1.0 \\
Desal 5DK & 0.44 & 2.3 \\
\hline
\end{tabular}

NF 270, Desal 5HL and Desal 5DK have the smallest mean pore radii, while NTR 7450 and NP030 appear to be more open, as expected. The effective membrane thickness for NF 270 and Desal $5 \mathrm{HL}$ is similar, whereas that for Desal DK is considerably larger, reflecting the relatively low permeance of Desal 5DK as compared to NF 270 and Desal $5 \mathrm{HL}$. The relatively high permeance of NTR 7450 as compared to NP030 is due to its lower effective thickness (see Table 5). Calculated retentions based on the obtained pore radii and effective membrane thicknesses describe the measured glucose retentions as function of flux well (see Fig. 2).

The mean pore radius determined for Desal $5 \mathrm{DK}(0.44 \mathrm{~nm})$ is close to those reported by Bargeman et al. [12] $(0.42 \mathrm{~nm}$ based on glucose retention and $0.44 \mathrm{~nm}$ based on glycerin retention), Bowen et al. [52] (0.43 nm based on glucose retention and $0.45 \mathrm{~nm}$ based on glycerol retention) and Straatsma et al. [7] (0.46 nm based on glucose retention). Mohammad et al. [38] have reported a slightly higher pore radius of $0.49 \mathrm{~nm}$. The effective thickness for this membrane of $2.3 \mu \mathrm{m}$ (see Table 5) is slightly lower than thicknesses reported by Bargeman et al. [12] $(2.59 \mu \mathrm{m})$, Straatsma et al. [7] $(3.13 \mu \mathrm{m})$ and Mohammad et al. [38] $(3.92 \mu \mathrm{m})$.

NTR 7450, reported to have a MWCO of $0.6-0.8 \mathrm{kDa}$ [41], is clearly more open than Desal $5 \mathrm{DK}$, Desal $5 \mathrm{HL}$ and NF 270. The mean pore radius for this membrane $(0.62 \mathrm{~nm}$, see Table 5$)$ is clearly lower than reported by Bargeman et al. $\left(r_{p}=1.34 \mathrm{~nm}\right.$ [12]) and Bowen and Mohammad ( $r_{p}=1.41 \mathrm{~nm}$ [34]). However, Schaep et al. [41] reported mean pore radii for NTR 7450 of $0.55 \mathrm{~nm}, 0.71 \mathrm{~nm}$ and $0.80 \mathrm{~nm}$ for solutions containing 
galactose, maltose, and raffinose, respectively, while Timmer et al. reported a pore radius for NTR 7450 of $0.76 \mathrm{~nm}$ [53] and $0.82 \mathrm{~nm}$ [54] on the basis of Paselli MD6 (glucose oligomers with sugar radii between 0.5 and $1.2 \mathrm{~nm}$ ) solution experiments. Wang et al. [55] reported a pore radius $(0.70 \mathrm{~nm})$ more in line with the radius obtained in this study and reported by Timmer et al. [53] and Schaep et al. [41] as well. The reason for the large spread in reported pore radii (and permeances as shown earlier) is not known. However, part of the explanation has recently been given by Shirley et al. [48], who showed that the dipole moment of the solute used and the concentration of the solutes with high dipole moment affects the obtained molecular weight cut-off and therefore the pore radius for NTR 7450 .

\subsection{The effect of $\mathrm{NaCl}$ concentration on $\mathrm{NaCl}$ retention for single solute solutions.}

For single $\mathrm{NaCl}$ solutions the $\mathrm{NaCl}$ retention for all membranes tested reduced strongly by increasing the salt concentration from $1 \mathrm{~g} \cdot \mathrm{L}^{-1}$ to $100 \mathrm{~g} \cdot \mathrm{L}^{-1}$. A reduction of the $\mathrm{NaCl}$ retention with increased $\mathrm{NaCl}$ concentration is in line with observations reported for several nanofiltration membranes in several other publications (e.g. [12, 31, 49, 51]). The $\mathrm{NaCl}$ retention for processing feed solutions containing $100 \mathrm{~g} \cdot \mathrm{L}^{-1}$ increased with increasing flux, but remained below $20 \%$ (and mostly below $15 \%$ ) for all membranes evaluated (results not shown). These results are in line with $\mathrm{NaCl}$ retentions reported by Tanninen et al. [31]. In their study a reduction in $\mathrm{NaCl}$ retention with increasing $\mathrm{NaCl}$ concentration was also observed, processing feeds with $\mathrm{NaCl}$ concentrations in the range between $0.04 \mathrm{M}\left(2.3 \mathrm{~g} . \mathrm{L}^{-1}\right)$ and $0.88 \mathrm{M}\left(51 \mathrm{~g} . \mathrm{L}^{-1}\right)$ at $\mathrm{T}=40^{\circ} \mathrm{C}$. The retention decrease reported by Tanninen et al. was especially strong when $\mathrm{NaCl}$ concentrations were increased from 0 to $10-15 \mathrm{~g} \cdot \mathrm{L}^{-1}$, while a further increase of the $\mathrm{NaCl}$ concentration led to a more gradual decrease in $\mathrm{NaCl}$ retention as function of $\mathrm{NaCl}$ concentration in the feed. For Desal 5DK, NF 270 and NF 20 a NaCl retention below $20 \%$ was reported for feeds containing $0.88 \mathrm{M}\left(51 \mathrm{~g}^{-\mathrm{L}^{-1}}\right) \mathrm{NaCl}$. Despite the considerable differences in $\mathrm{NaCl}$ retention for the various membranes during processing of the $1 \mathrm{~g} \cdot \mathrm{L}^{-1} \mathrm{NaCl}$ solution, the differences in retention for processing a $100 \mathrm{~g}^{-\mathrm{L}^{-1}} \mathrm{NaCl}$ solution were consequently limited in our study. This observation is in line with results presented by Tanninen et al. [31] as well. The $\mathrm{NaCl}$ retention for nanofiltration membranes is generally believed to be caused by Donnan exclusion, since ion radii for this salt are much smaller than the pore radii of commonly used nanofiltration membranes. This is indeed valid for low $\mathrm{NaCl}$ concentrations (see e.g. [7, 12]). However, the influence of this (Donnan) separation mechanism becomes less important for feed solutions with a high ionic strength, as 
indicated by the reduction of $\mathrm{NaCl}$ retention at higher $\mathrm{NaCl}$ concentrations. This also justifies why zeta potential measurements have not been conducted, since these measurements will not provide any insights in the salt retention characteristics of nanofiltration membranes during processing of concentrated solutions.

Furthermore, for processing feeds containing $100 \mathrm{~g} \cdot \mathrm{L}^{-1} \mathrm{NaCl}$ or more, there is only a minor effect of the $\mathrm{NaCl}$ concentration on $\mathrm{NaCl}$ retention see Fig. 3), and retentions remain low, showing the low resistance of the evaluated nanofiltration membranes for $\mathrm{NaCl}$ transport at high $\mathrm{NaCl}$ concentrations. It should be noted that for solutions containing $100 \mathrm{~g} \cdot \mathrm{L}^{-1} \mathrm{NaCl}$ or more at membrane fluxes lower than $20 \mathrm{~L} \cdot \mathrm{m}^{-2} \cdot \mathrm{h}^{-1}$ the observed $\mathrm{NaCl}$ retention reduced when flux was reduced, irrespective of the salt concentration in the feed. At very low fluxes retentions became practically zero (results not shown). This behavior was observed for all nanofiltration membranes evaluated.

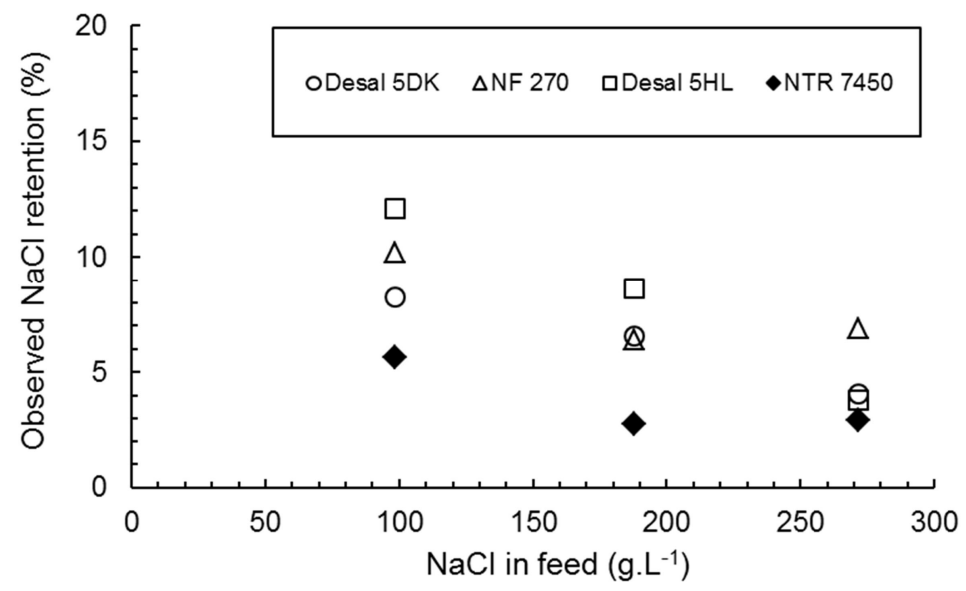

Figure 3: The effect of $\mathrm{NaCl}$ concentration in the feed on observed $\mathrm{NaCl}$ retention at a flux of $25 \mathrm{~L} \cdot \mathrm{m}^{-2} \cdot \mathrm{h}^{-1}$ at room temperature for Desal $5 \mathrm{HL}$, Desal $5 \mathrm{DK}, \mathrm{NF}$ 270 and NTR 7450.

4.5. The effect of the $\mathrm{NaCl}$ concentration on glucose retention and membrane characteristics

The $\mathrm{NaCl}$ concentration in a $1 \mathrm{~g} \cdot \mathrm{L}^{-1}$ glucose solution strongly affects the glucose retention. This is illustrated for Desal $5 \mathrm{DK}$ and Desal $5 \mathrm{HL}$ in Figure 4, where the 
glucose retention is shown as function of the membrane flux for a $1 \mathrm{~g} \cdot \mathrm{L}^{-1}$ glucose solution containing different $\mathrm{NaCl}$ concentrations. The observed reduction in glucose retention is not (only) due to the reduction in flux at higher $\mathrm{NaCl}$ concentrations, but is clearly caused by the $\mathrm{NaCl}$ concentration for all membranes evaluated. For operation at a membrane flux of $25 \mathrm{~L} . \mathrm{m}^{-2} \cdot \mathrm{h}^{-1}$ the glucose retention as function of the $\mathrm{NaCl}$ concentration shows a similar pattern for NF 270, Desal 5DK and Desal 5HL (see Fig. $5)$, although the reduction in glucose retention as a consequence of the increase in $\mathrm{NaCl}$ concentration in the feed seems to be slightly lower for Desal $5 \mathrm{HL}$ and slightly higher for NF 270. It should be noted that glucose retention results at $25 \mathrm{~L} \cdot \mathrm{m}^{-2} \cdot \mathrm{h}^{-1}$ for NF 270 and Desal $5 \mathrm{HL}$ during processing of the $1 \mathrm{g.L}^{-1}$ glucose solution without $\mathrm{NaCl}$ are extrapolated values on the basis of the calculated ratio of pore radius over glucose radius and the effective diameter. During operation at a flux of $25 \mathrm{~L} \cdot \mathrm{m}^{-2} \cdot \mathrm{h}^{-1}$ the glucose retention for NF 270 dropped from approximately $98 \%$ at $0 \mathrm{~g} \cdot \mathrm{L}^{-1} \mathrm{NaCl}$ in the feed solution to $69 \%$ for 275 g. $\mathrm{L}^{-1} \mathrm{NaCl}$ in the feed, while for Desal $5 \mathrm{HL}$ and Desal $5 \mathrm{DK}$ the glucose retention dropped from $93 \%$ to $77 \%$, and $94 \%$ to $73 \%$, respectively. It should be noted that for operation at a flux of $25 \mathrm{~L} \cdot \mathrm{m}^{-2} \cdot \mathrm{h}^{-1}$ obviously a higher trans-membrane pressure is required for processing of feeds containing more $\mathrm{NaCl}$ as a consequence of the higher viscosity of the permeate at higher $\mathrm{NaCl}$ concentration. For Desal 5DK a reduction of the glucose retention from $98 \%$ to $95 \%$ was reported earlier by Bargeman et al. [12] for processing solutions containing $1.5 \mathrm{~g} \cdot \mathrm{kg}^{-1}$ glucose and either no $\mathrm{NaCl}$ or $1.0 \mathrm{M}\left(58.5 \mathrm{~g} \cdot \mathrm{L}^{-1}\right) \mathrm{NaCl}$ at a flux of $75 \mathrm{~kg} \cdot \mathrm{m}^{-2} \cdot \mathrm{h}^{-1}$.

NTR 7450 showed a decrease in observed glucose retention from $58 \%$ to $39 \%$ over the $\mathrm{NaCl}$ concentration range (see Fig. 5), while for NP 030 only a limited effect of the $\mathrm{NaCl}$ concentration on the glucose retention was found. It should be noted that the glucose retention obtained for NTR 7450 was quite different from that found in [12], indicating strong variations in membrane quality for these membrane sheets as mentioned before. 

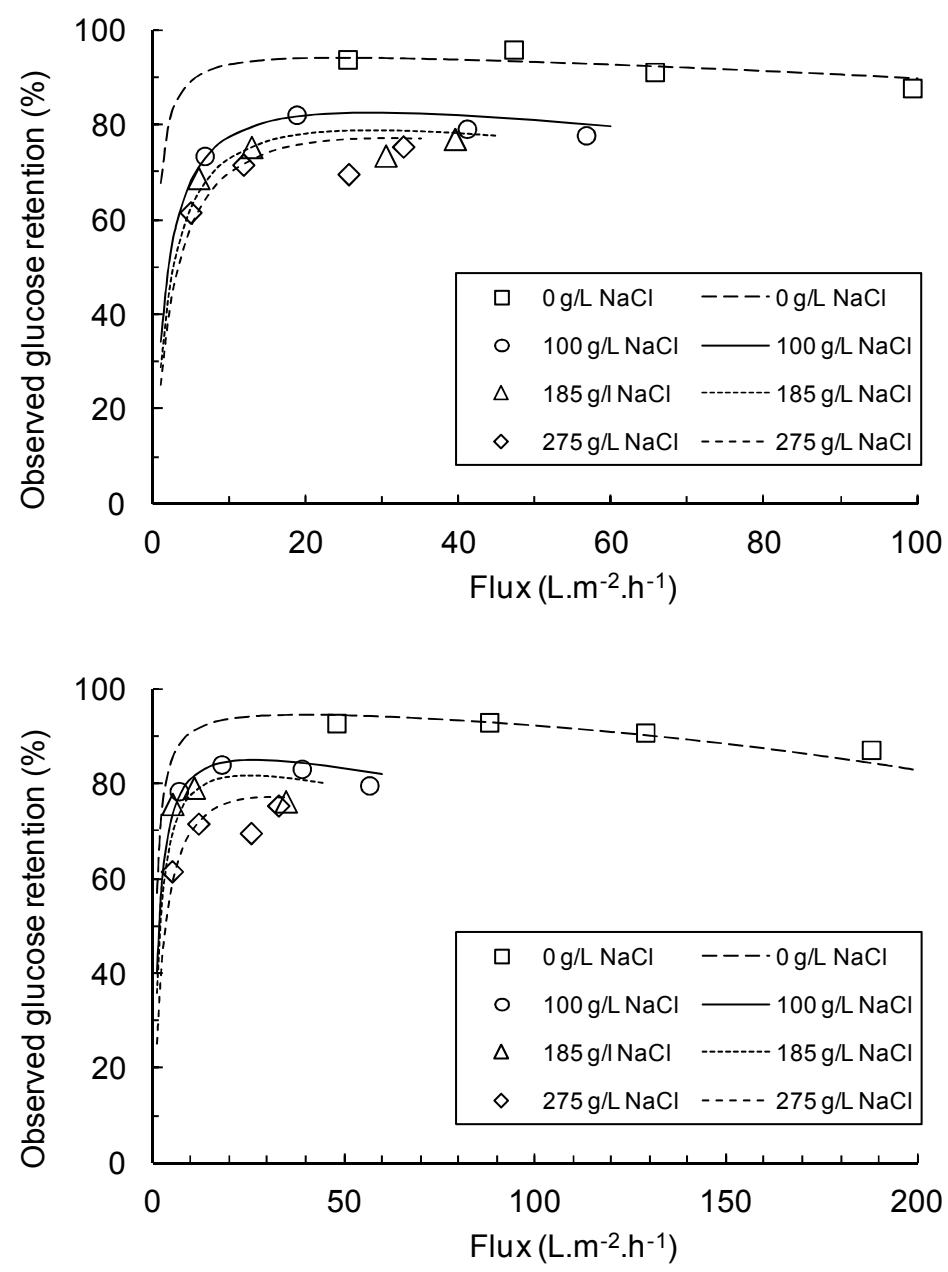

Figure 4: Effect of flux and $\mathrm{NaCl}$ concentration on the observed glucose retention for Desal 5DK (top) and Desal 5HL (bottom) processing a $1{\mathrm{~g} . \mathrm{L}^{-1}}^{-1}$ glucose solution containing different salt concentrations (symbols are measured values and lines are calculated values based on pore radius and effective thickness reported in Tables 5 and 6 ). 


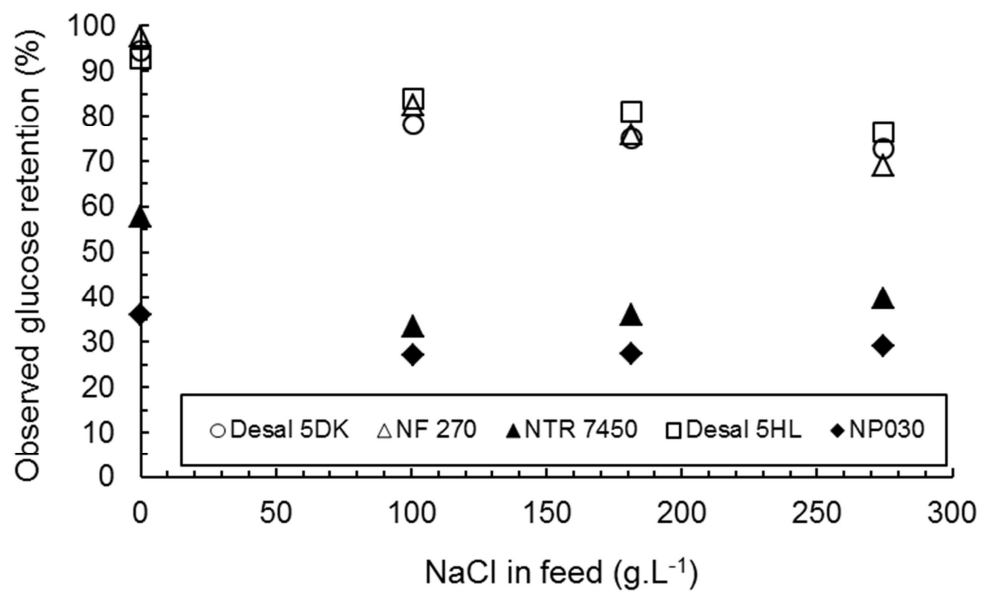

Figure 5: Effect of $\mathrm{NaCl}$ concentration in feed on the observed glucose retention operating at $25 \mathrm{~L} . \mathrm{m}^{-2} \cdot \mathrm{h}^{-1}$ processing a $1 \mathrm{~g} \cdot \mathrm{L}^{-1}$ glucose solution with different $\mathrm{NaCl}$ concentrations.

Table 6: Estimated effective pore radius and effective thickness for Desal 5HL, NF 270 and Desal 5DK as function of the $\mathrm{NaCl}$ concentration in the feed solution (assuming a constant glucose radius of $0.36 \mathrm{~nm}$ ).

\begin{tabular}{|c|c|c|c|c|c|c|c|c|}
\hline Feed & \multicolumn{2}{|c|}{$1 \mathrm{~g} \cdot \mathrm{L}^{-1}$ glucose } & \multicolumn{2}{|c|}{$\begin{array}{c}1 \text { g. } \mathrm{L}^{-1} \text { glucose } \\
+100 \mathrm{~g}^{-\mathrm{L}^{-1}}\end{array}$} & \multicolumn{2}{|c|}{$\begin{array}{c}1 \text { g. } \mathrm{L}^{-1} \text { glucose } \\
+185 \mathrm{~g} \cdot \mathrm{L}^{-1}\end{array}$} & \multicolumn{2}{|c|}{$\begin{array}{l}1{\mathrm{~g} . \mathrm{L}^{-1} \text { glucose }}+275 \mathrm{~g} \cdot \mathrm{L}^{-1}\end{array}$} \\
\hline $\begin{array}{l}\text { Membrane } \\
\text { characteristics }\end{array}$ & $\begin{array}{c}r_{p} \\
(n m)\end{array}$ & $\begin{array}{l}\Delta x / A_{k} \\
(\mu \mathrm{m})\end{array}$ & $\begin{array}{c}r_{p} \\
(n m)\end{array}$ & $\begin{array}{r}\Delta \mathrm{x} / \mathrm{A}_{k} \\
(\mu \mathrm{m})\end{array}$ & $\begin{array}{c}r_{p} \\
(n m)\end{array}$ & $\begin{array}{l}\Delta \mathrm{x} / \mathrm{A}_{\mathrm{k}} \\
(\mu \mathrm{m})\end{array}$ & $\begin{array}{c}\mathrm{r}_{\mathrm{p}} \\
(\mathrm{nm})\end{array}$ & $\begin{array}{l}\Delta \mathrm{x} / \mathrm{A}_{\mathrm{k}} \\
(\mu \mathrm{m})\end{array}$ \\
\hline Desal 5HL & 0.43 & 1.2 & 0.51 & 4.2 & 0.53 & 6.2 & 0.54 & 6.8 \\
\hline NF 270 & 0.41 & 1.0 & 0.51 & 3.7 & 0.53 & 5.4 & 0.52 & 6.4 \\
\hline Desal 5DK & 0.44 & 2.3 & 0.52 & 4.3 & 0.54 & 5.8 & 0.55 & 5.6 \\
\hline
\end{tabular}

The effective pore radius and the effective thickness for the individual membranes calculated on the basis of the glucose retention obtained for the individual membranes during processing of each feed solution containing $1 \mathrm{~g} . \mathrm{L}^{-1}$ glucose and different salt concentrations are listed in Table 6 . The procedure used for determination of the 
effective pore radius and thickness has been explained earlier. During this procedure it was assuming that the viscosity of the permeate was similar to that for a $\mathrm{NaCl}$ solution of either $100 \mathrm{~g} . \mathrm{L}^{-1}, 185 \mathrm{~g} . \mathrm{L}^{-1}$ or $275 \mathrm{~g} . \mathrm{L}^{-1}$. This provides an indication of the effective thickness, sufficient for recognizing trends. Viscosity values for the sodium chloride containing permeates, as used during the modelling procedure, were obtained from the Handbook of Chemistry and Physics [56]. Information in this reference furthermore clearly indicates that the presence of glucose at low concentrations does not change the viscosity of the solution to a significant extent, justifying the earlier described assumption to neglect the effect of the presence of glucose on viscosity. The product flux was used instead of the pure water flux for calculation of the effective membrane thickness as it is believed that the obtained effective membrane thickness is affected by the liquid processed.

Required osmotic pressures were obtained from flux measurements as function of the operating pressure as described by equation (13) in the theoretical background section.

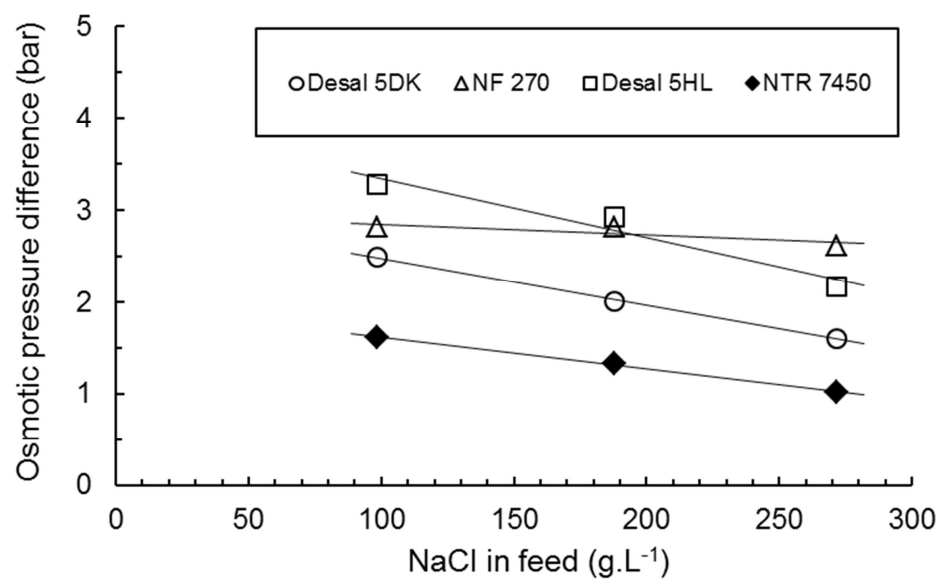

Figure 6: Effect of $\mathrm{NaCl}$ feed concentration on the osmotic pressure difference between retentate and permeate $\Delta \pi$ for processing a $1 \mathrm{~g} . \mathrm{L}^{-1}$ glucose solution with different $\mathrm{NaCl}$ concentrations.

Despite the high salt concentrations in the feed solution, osmotic pressure differences for the different nanofiltration membranes are below 3.5 bar (see Fig, 6). These relatively low osmotic pressure differences are due to the low sodium chloride 
retentions obtained for these membranes during nanofiltration of concentrated sodium chloride solutions, and the low glucose concentration in the feed. An increase in sodium chloride concentration results in a lower osmotic pressure difference for most of the membranes, and especially for Desal $5 \mathrm{HL}$ and Desal 5DK. This reduction in osmotic pressure difference as function of the sodium chloride concentration in the feed is in line with the observed reduction in sodium chloride retention when the salt concentration in the feed is increased (see Fig. 3). The reduction in osmotic pressure difference for NTR 7450 and NF 270 with increasing sodium chloride concentration is less strong as expected on the basis of their retention behavior (see Fig. 3). Osmotic pressures for NP030 were negligible for all salt concentrations in the feed.

As reported by Bargeman et al. [12] for Desal 5DK processing solutions containing $0.15 \% \mathrm{w}$ glucose and $10^{-3}-1 \mathrm{M}\left(0.0585-58.5 \mathrm{~g} . \mathrm{L}^{-1}\right) \mathrm{NaCl}$, an increase in effective pore radius is found when salt is present in the glucose solution (assuming constant glucose radius). For Desal $5 D K$ the increase in effective pore radius found in the current study is relatively high as compared to that reported in [12], although it should be realized that the models used to obtain the pore radii were different, which may have affected the values obtained. Furthermore, the effective radius for this membrane seems to increase further even at high $\mathrm{NaCl}$ concentrations. For NF 270 and Desal $5 \mathrm{HL}$ the effective pore radius also increases slightly when the $\mathrm{NaCl}$ concentration in the feed is increased from $100 \mathrm{~g} . \mathrm{L}^{-1}$ via $185 \mathrm{~g} \cdot \mathrm{L}^{-1}$ to $275 \mathrm{~g} . \mathrm{L}^{-1}$. For Desal $5 \mathrm{HL}$ and NF 270 the addition of $100 \mathrm{~g} . \mathrm{L}^{-1}$ $\mathrm{NaCl}$ to a $1 \mathrm{~g} . \mathrm{L}^{-1}$ glucose solution, starting from a pure glucose solution also results in a considerable increase of the effective pore radius (see Table 6). When salt is added to the $1 \mathrm{~g} \cdot \mathrm{L}^{-1}$ glucose solution the effective thickness also increases substantially. As can be seen in Figure 4, the model results based on the fitted pore radius and effective thickness describe the obtained glucose retentions well.

Explanations for this observed phenomenon are in line with earlier publications. Bargeman et al. [12] proposed two hypotheses to explain the results obtained. The reduced glucose retention in the presence of salt could be caused by an increased effective average pore radius as a consequence of the presence of pore size distribution and relatively more liquid flowing through the larger pores, or a real increase in the actual radius of the pores present in the membranes due to higher repulsion forces caused by higher membrane surface charges when salts are present in the solution. Effects of the pore size distribution on retention for single component solutions 
have been described by Bowen and Welfoot [49] as well. Due to the presence of a pore size distribution a smaller fraction of the permeate flows through the smaller pores when the flux reduces as shown by Bargeman et al. [12]. This means that the glucose retention will decrease, but it can also mean that part of the smaller pores do not contribute to the flow anymore or to a lesser extent. This can result in a smaller effective void fraction and can be an explanation for the higher effective thickness found. Furthermore, swelling of the membrane as a consequence of the presence of salt in the membrane pores can also occur. This increases the thickness of the membrane separation layer, causing an increase in pore size, but at the same time an increase in effective thickness [12]. Recently, spectroscopic ellipsometry has been used to look at swelling of the top layer of the membrane during nanofiltration of solvents [57]. Evaluation of nanofiltration membranes during processing of concentrated salt solutions using the same technique could potentially contribute to further clarifying which mechanisms are responsible for the observed effect of salts on retention of neutral components such as glucose. Bouchoux et al. [13] have added another possible explanation for the observed reduction in glucose retention at higher $\mathrm{NaCl}$ concentrations. This could be due to a smaller glucose Stokes radius caused by reduced glucose hydration as a consequence of the higher $\mathrm{NaCl}$ concentration.

In our calculations, the glucose radius was assumed to be independent of the salt concentration. However it is realized that this is not necessarily true as shown in [22], where both a reduction in pore radius and solute radius are shown to give the increase in neutral solute retention. In fact, a smaller value for the glucose radius at higher salt concentrations would have resulted in a smaller increase of the effective pore radius, but still, it is expected that an increase of the effective pore radius would still be required to explain the observed experimental results. Since, to the best of our knowledge, proper glucose solute radii are not available for solutions containing different salt concentrations some authors (e.g. [24]) use the ratio of the glucose radius over the pore radius to interpret the effect of sodium chloride concentration on glucose retention. However, this means that they either implicitly assume a specific value for the solute radius to be able to obtain a specific value for the pore radius $r_{p}$, which is needed in equation (12) or (13), or they solve the set of equations simultaneously without taking the Hagen-Poiseuille equation (12) or (13) into account. The latter approach will lead to multiple solutions for $r_{p} / r_{s}$ and the effective thickness. Obviously, there is a need for the determination of solute radii for glucose in salt solutions to further improve insights in 
the effects of salt on nanofiltration membrane characteristics. However, this is outside of the scope of the current study.

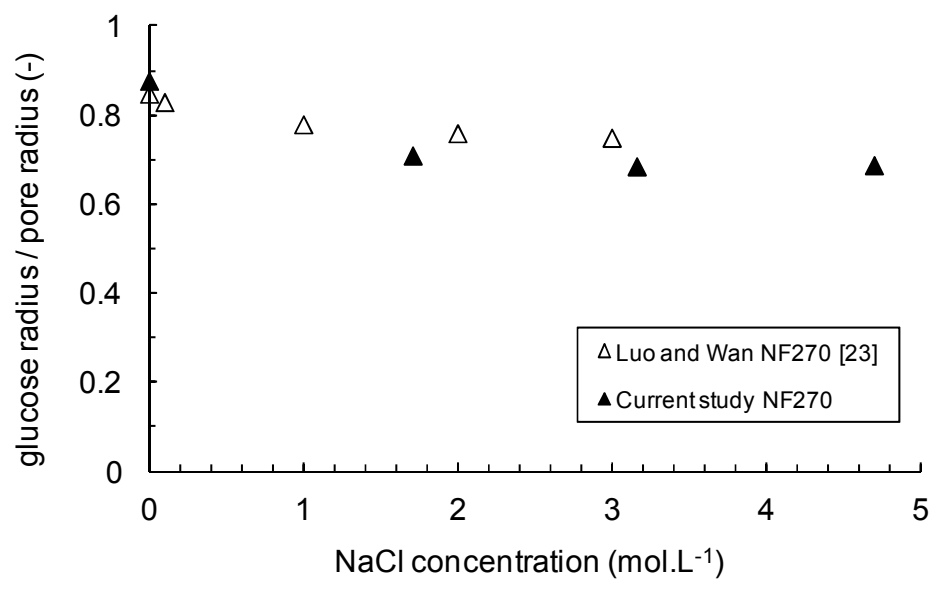

Figure 7: The ratio of the glucose radius over mean pore radius $(\lambda)$ as function of the $\mathrm{NaCl}$ concentration in the solution for NF 270 based on results from the current study and from Luo and Wan [24].

For NF 270 Luo and Wan [24] have presented results for the ratio of glucose ratio over pore radius obtained on the basis of extended Nernst-Plank modeling of experimental results processing solutions of $15 \mathrm{~g} \cdot \mathrm{L}^{-1}$ glucose with $\mathrm{NaCl}$ concentrations as high as 3 mol. $L^{-1}$ (see Fig. 7). When comparing their results with the results obtained in the current study it is seen that both studies show a reduction of the ratio of glucose radius over mean pore radius, when the $\mathrm{NaCl}$ concentration in the solution is increased. For the current study this reduction for NF 270 is larger than obtained by Luo and Wan [24].

This is further illustrated in Figure 8 top, where the change in the ratio of the glucose radius over pore radius $\left(\Delta \lambda=\lambda_{\mathrm{NaCl}=\mathrm{o}}-\lambda_{\mathrm{NaCl}=\mathrm{x}}\right)$ as a consequence of the addition of salt is shown as function of the sodium chloride concentration. For NF 270 the changes in this ratio $(\Delta \lambda)$ obtained in the current study are twice as high as the $\Delta \lambda$ found by Luo and Wan [24], who determined $\Delta \lambda$ as function of the $\mathrm{NaCl}$ concentration for NF 270 and Desal 5DL. For the two Desal membranes evaluated in our study (Desal 5DK and Desal $5 \mathrm{HL}$ ) the changes in the ratio as a consequence of the addition of $\mathrm{NaCl}$ are higher as 
well, but only by approximately a factor 1.5 . Earlier results obtained by Bargeman et al. [12] for Desal 5DK and NF gave slightly higher values for $\Delta \lambda$ as well.

From their work it seems that Luo and Wan [24] did not use the Hagen-Poiseuille relation, but merely solved equations (9) and (11) by fitting the pore radius and the effective thickness. Since this would mean that they have solved a single equation by fitting two parameters it would mean that multiple solutions would be available. Since most other publications erroneously use the Hagen-Poiseuille equation based on the pure water flux (equation (12)) as other equation to obtain a single solution for the pore radius and the effective thickness, we have evaluated the effect of using this equation instead of equation (13) on the change in $\Delta \lambda$ as well. The results are shown in Figure 8 (bottom). Although there are still some small deviations from the correlation proposed by Luo and Wan [24], the results now seem to be more in line with their correlation. 

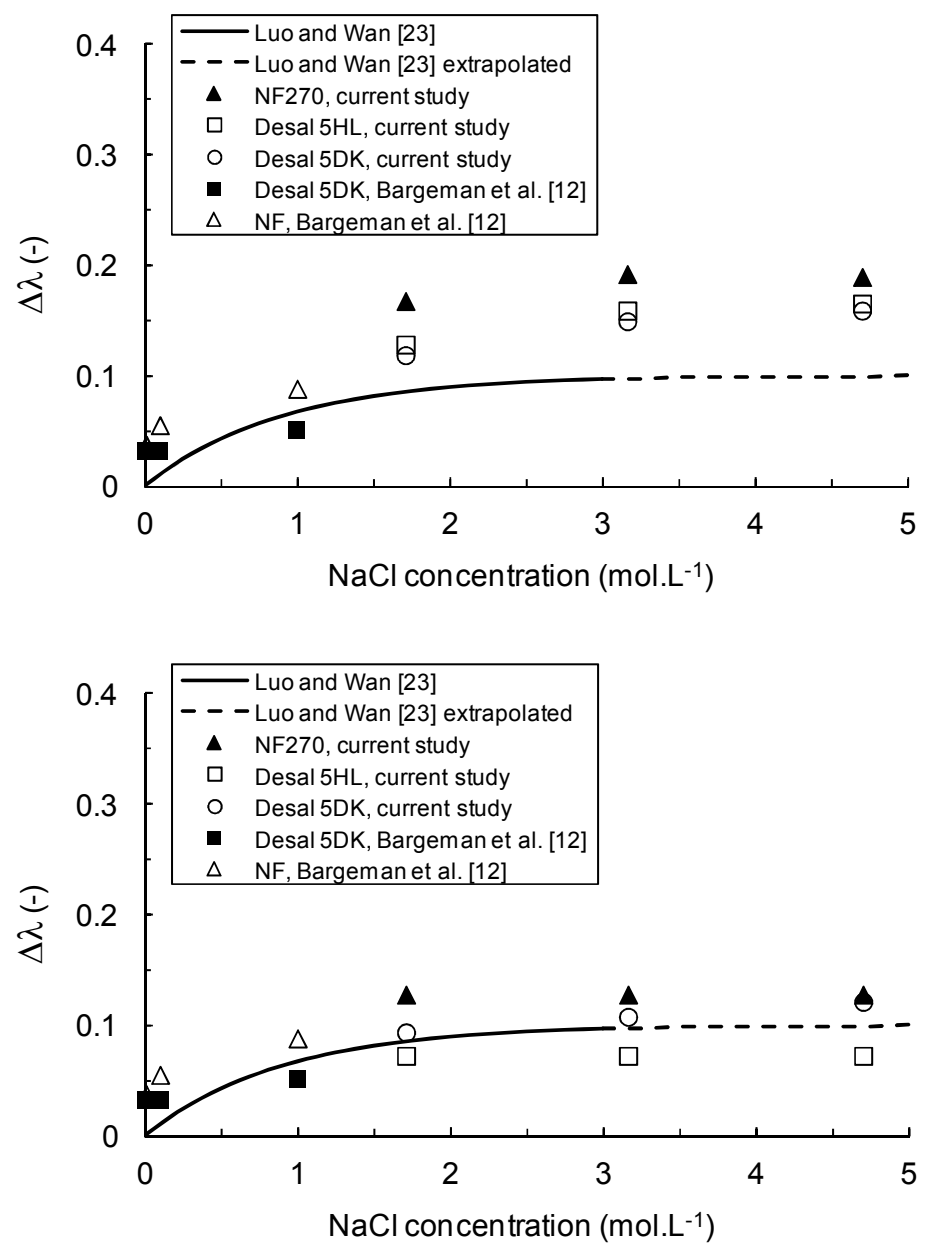

Figure 8: The change in the ratio of glucose radius over mean pore radius $(\Delta \lambda)$ as function of the $\mathrm{NaCl}$ concentration in the solution related to the correlation determined by Luo and Wan for NF 270 and Desal 5DL [24]. Results from the current study and experimental results reported by Bargeman et al. [12] for Desal 5DK and NF (top). Results from the current study using effective thicknesses and pore radii using equation (12) based on the clean water permeability and experimental results reported by Bargeman et al. [12] for Desal 5DK and NF (bottom). 


\subsection{Effect of glucose concentration on glucose retention.}

The glucose concentration hardly affects its own retention for processing of solutions containing $175 \mathrm{~g} . \mathrm{L}^{-1} \mathrm{NaCl}$ or more, as long as operation at similar flux is compared. This is illustrated for Desal 5DK and NF 270 in Fig. 9. For these membranes the retention for processing a solution containing $80 \mathrm{~g} \cdot \mathrm{L}^{-1}$ glucose and either $175 \mathrm{~g} . \mathrm{L}^{-1} \mathrm{NaCl}$ or $275 \mathrm{~g} . \mathrm{L}^{-1}$ $\mathrm{NaCl}$ can be predicted quite well using the effective thickness and the ratio of pore radius over glucose radius obtained for a solution containing $1 \mathrm{~g} \cdot \mathrm{L}^{-1}$ glucose and 275 g. $\mathrm{L}^{-1} \mathrm{NaCl}$.

Table 7: Osmotic pressure differences for evaluated nanofiltration membranes during processing of solutions containing $80 \mathrm{~g}^{-\mathrm{L}^{-1}}$ glucose and either 175 g. $\mathrm{L}^{-1} \mathrm{NaCl}$ or $275 \mathrm{~g} \cdot \mathrm{L}^{-1} \mathrm{NaCl}$.

\begin{tabular}{cc}
\hline Nanofiltration membrane & $\begin{array}{c}\text { Osmotic pressure difference } \\
(\mathrm{bar})\end{array}$ \\
\hline Desal 5DK & $6-7$ \\
Desal 5HL & 7 \\
NP 30 & $0-1$ \\
NTR 7450 & $2-3$ \\
NF 270 & $8-9$ \\
\hline
\end{tabular}

When comparing the retentions at similar operating pressure a difference in glucose retention can be observed, since the flux for feed solutions containing considerable amounts $\left(80 \mathrm{~g}^{\mathrm{L}} \mathrm{L}^{-1}\right)$ of glucose will be lower than those for feed solutions containing limited amounts of glucose $\left(1 \mathrm{~g} \cdot \mathrm{L}^{-1}\right)$, and the flux has a clear influence on the glucose retention below flux values of $8 \mathrm{~L} \cdot \mathrm{m}^{-2} \cdot \mathrm{h}^{-1}$ (see Fig. 9). The flux reduction at higher glucose feed concentrations for similar operating pressures is attributed to a higher permeate viscosity and osmotic pressure difference between concentrate and permeate (see Table 7). The higher osmotic pressure difference than obtained for nanofiltration of the solutions containing $\mathrm{NaCl}$ and only $1 \mathrm{~g} \cdot \mathrm{L}^{-1}$ glucose originates from the high glucose concentration in the feed and the substantial glucose retention. Furthermore, the membranes showing relatively high glucose retention during processing of the salt solutions containing $80 \mathrm{~g} \cdot \mathrm{L}^{-1}$ glucose show relatively high osmotic pressure differences as well, as expected. For Desal $5 \mathrm{HL}$ the retention trend is similar to that for NF 270 (results not shown). 

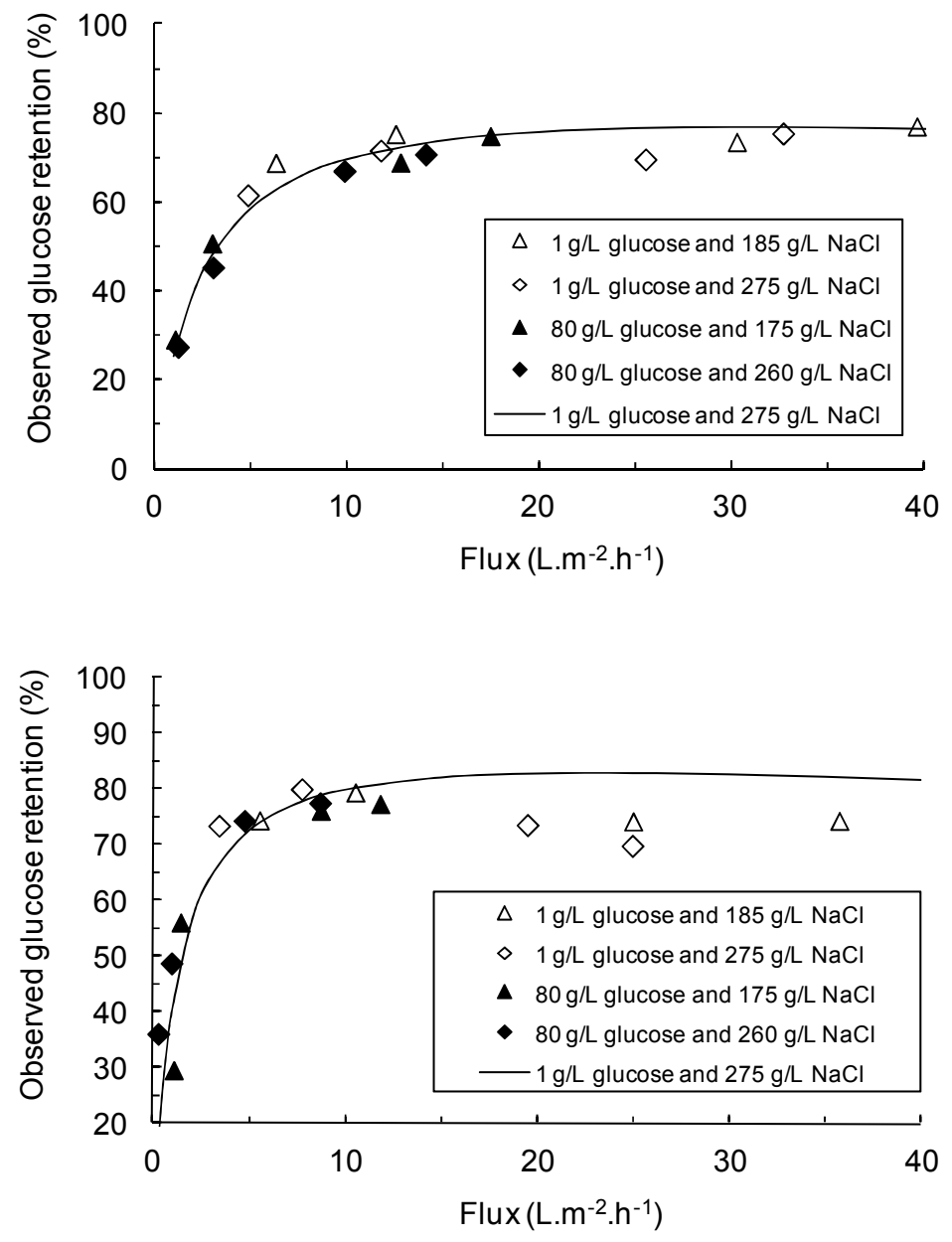

Figure 9: The effect of flux, glucose and $\mathrm{NaCl}$ concentration in the feed on observed glucose retention for Desal 5DK (top) and NF 270 (bottom) at room temperature (symbols are measured values and the line represents calculated values for $1 \mathrm{~g} . \mathrm{L}^{-1}$ glucose and $275 \mathrm{~g} . \mathrm{L}^{-1} \mathrm{NaCl}$ based on mean pore radius and effective thickness reported in Table 6).

For NTR 7450 the glucose retention during processing of feeds containing $80 \mathrm{~g} \cdot \mathrm{L}^{-1}$ glucose (and high $\mathrm{NaCl}$ concentrations) was substantially higher than for processing of 
feeds containing $1 \mathrm{~g} . \mathrm{L}^{-1}$ glucose and similar $\mathrm{NaCl}$ concentrations (see Fig. 10). This shows that the trends obtained for NF 270 and Desal 5DK as shown in Figure 9 are not evident. The observed higher glucose retention at higher glucose concentration for NTR 7450 is recently reported by Shirley et al. [48] as well, for solutions that contained glucose only. A unique explanation for the observed phenomenon cannot be given. However, hypothetically the following phenomena could explain the observations. For NTR 7450 the pore radius of the (swollen) membrane, as a consequence of the presence of the sodium chloride, is approximately twice the glucose radius. It may be that due to the high concentration of glucose, this leads to more interaction between the glucose molecules and therefore more friction inside the pores, leading to higher retention for glucose at higher glucose concentration. It is furthermore known that NTR 7450 is very sensitive to membrane compaction (as shown in Bargeman et al. [12]). Since the viscosity of the $80 \mathrm{~g} \cdot \mathrm{L}^{-1}$ glucose solution is higher than for the $1 \mathrm{~g} . \mathrm{L}^{-1}$ glucose solution this means that a higher pressure is needed to obtain similar flux. This means that for processing of the $80 \mathrm{~g} \cdot \mathrm{L}^{-1}$ glucose solution, the membrane may be more compacted than for processing the $1 \mathrm{~g} \cdot \mathrm{L}^{-1}$ glucose solution. This could be reflected in higher glucose retentions at similar flux (as shown in Fig. 10). Obviously, more reasons can be thought of and additional study would be required to elucidate the reasons for this phenomenon.

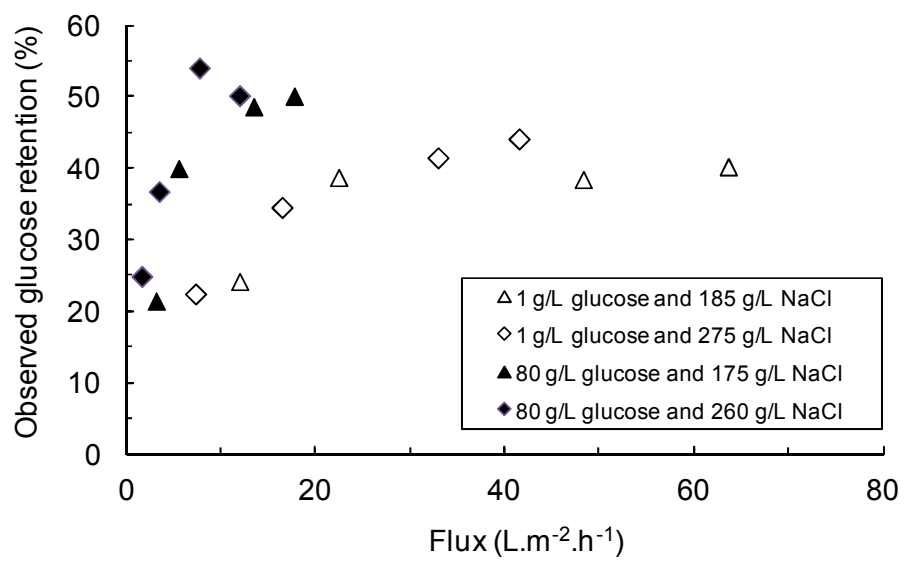

Figure 10: The effect of flux, glucose and $\mathrm{NaCl}$ concentration in the feed on observed glucose retention for NTR 7450 at room temperature. 
For NP 030 (results not shown) a trend similar to that for Desal 5DK, Desal 5HL and NF 270 was found, albeit at much lower glucose retention level.

\section{7. $\mathrm{NaCl}$ retention at high glucose feed concentration.}

For nanofiltration of concentrated $\mathrm{NaCl} /$ glucose solutions, observed $\mathrm{NaCl}$ retentions based on $\mathrm{NaCl}$ concentrations analyzed in concentrate and permeate $\left(\mathrm{R}=1-\left(\mathrm{C}_{\mathrm{NaCl}, \mathrm{p}}\right)\right.$ $\mathrm{C}_{\mathrm{NaCl}, \mathrm{C}}$ )) have been determined as function of the observed difference in glucose concentration between concentrate and permeate. Results are shown in Fig. 11 for nanofiltration of a $260 \mathrm{~g} \cdot \mathrm{L}^{-1} \mathrm{NaCl} / 80 \mathrm{~g} \cdot \mathrm{L}^{-1}$ glucose solution (top left, a), and a $175 \mathrm{~g} . \mathrm{L}^{-1}$ $\mathrm{NaCl} / 80 \mathrm{~g} \cdot \mathrm{L}^{-1}$ glucose solution (bottom left, b), respectively. For all nanofiltration membranes evaluated (NP 030, Desal 5HL, Desal 5DK, NTR 7450 and NF 270) the $\mathrm{NaCl}$ retention obtained appears to be close to zero (slightly positive for some membranes and slightly negative for others). The $\mathrm{NaCl}$ retentions are only marginally dependent on the difference in glucose concentration between concentrate and permeate (see Figs. 11a and 11b). At higher glucose concentration differences, slightly negative $\mathrm{NaCl}$ retentions are observed, as stated earlier. In first instance this seems to be surprising, however, this observation is caused by the presence of considerable amounts of glucose in the feed and the relatively high retention of glucose for the tighter membranes (resulting in considerably higher glucose concentrations in concentrate than in permeate). Since for cases with high differences in glucose concentration between concentrate and permeate, glucose retention and glucose concentration in feed are relatively high, permeates contain very limited amounts of glucose. Thus, the membrane characteristics and membrane resistance for $\mathrm{NaCl}$ transport are similar and permeates obtained resemble those obtained during processing of similar salt solutions without glucose. However, since the retentate is more diluted by glucose compared to the retentate for processing of $\mathrm{NaCl}$ solutions without glucose, the retentate $\mathrm{NaCl}$ concentration is lower when glucose is present in the retentate. Therefore, the $\mathrm{NaCl}$ retention, which was already close to zero for solutions not containing any glucose at all (especially for situations where the flux was below $20 \mathrm{~L} \cdot \mathrm{m}^{-2} \cdot \mathrm{h}^{-1}$, which is found for the tight membranes during processing of $80 \mathrm{~g}^{-1} \mathrm{~L}^{-1}$ glucose containing feed solutions as well), can now drop to negative values. To illustrate that indeed $\mathrm{NaCl}$ retentions for solutions without glucose and solutions containing glucose are similar when $\mathrm{NaCl}$ retentions are based on the $\mathrm{NaCl}$ and water fractions only (excluding glucose), the following alternative retentions are calculated: 
$\mathrm{R}_{\mathrm{NaCl}, \mathrm{alt}}=1-\left(\mathrm{X}_{\mathrm{NaCl}, \mathrm{p}} / \mathrm{X}_{\mathrm{NaCl}, \mathrm{C}}\right)$

with: $\mathrm{x}_{\mathrm{NaCl}, \mathrm{p}}=\mathrm{w}_{\mathrm{NaCl}, \mathrm{p}} /\left(\mathrm{w}_{\mathrm{NaCl}, \mathrm{p}}+\mathrm{w}_{\mathrm{H} 2 \mathrm{O}, \mathrm{p}}\right)$ and $\mathrm{x}_{\mathrm{NaCl}, \mathrm{C}}=\mathrm{w}_{\mathrm{NaCl}, \mathrm{c}} /\left(\mathrm{w}_{\mathrm{NaCl}, \mathrm{C}}+\mathrm{w}_{\mathrm{H} 2 \mathrm{O}, \mathrm{c}}\right)$

Indeed, slightly positive alternative $\mathrm{NaCl}$ retentions $\mathrm{R}_{\mathrm{NaCl}}$, alt, very close to zero are obtained (see Figs. 11c and 11d) for both feeds $\left(260 \mathrm{~g} \cdot \mathrm{L}^{-1} \mathrm{NaCl} / 80 \mathrm{~g} \cdot \mathrm{L}^{-1}\right.$ glucose solution and 175 g. $\mathrm{L}^{-1} \mathrm{NaCl} / 80 \mathrm{~g} \cdot \mathrm{L}^{-1}$ glucose solution), irrespective of the glucose concentration difference between concentrate and permeate. This observation confirms the occurrence of a very low membrane resistance for $\mathrm{NaCl}$ transport for all membranes evaluated, as can be expected for these high $\mathrm{NaCl}$ concentrations. Since the resistance for glucose transport through especially the tighter membranes is much higher than for $\mathrm{NaCl}$ transport (as reflected by the relatively high glucose retention), the $\mathrm{NaCl}$ in the concentrate is diluted to a larger extent by the presence of glucose than the $\mathrm{NaCl}$ in permeate as explained earlier. This causes a stronger drop in $\mathrm{NaCl}$ concentration in concentrate than in permeate and thus leads to the observed negative $\mathrm{NaCl}$ retention. The observed negative retention at higher concentrations is therefore not an artifact, but due to the presence of high amounts of glucose in the concentrate (relative to permeate) and an only marginally higher resistance during transport for $\mathrm{NaCl}$ compared to water as mentioned earlier.

As shown, the difference in glucose concentration between concentrate and permeate does not seem to affect the $\mathrm{NaCl}$ retention to a large extent. This is quite different from nanofiltration of solutions saturated in $\mathrm{NaCl}$ and $\mathrm{Na}_{2} \mathrm{SO}_{4}$, where higher differences in sulfate concentrations between concentrate and permeate resulted in more negative $\mathrm{NaCl}$ retentions [26]. Clearly, glucose and sodium sulfate show a quite different 'saltingout' behavior for sodium chloride during nanofiltration.

For solutions containing only $1 \mathrm{~g} \cdot \mathrm{L}^{-1}$ glucose and $\mathrm{NaCl}$ concentrations in excess of 100 g. $\mathrm{L}^{-1} \mathrm{NaCl}$, at low flux $\mathrm{NaCl}$ retentions of approximately zero were obtained as well. However, at higher flux the $\mathrm{NaCl}$ retention increased, as illustrated for Desal DK and NF 270 in Figure 12 (top) and (bottom), respectively. This trend is in line with the effect of flux on $\mathrm{NaCl}$ retention for $\mathrm{NaCl}$ solutions that do not contain any glucose. 

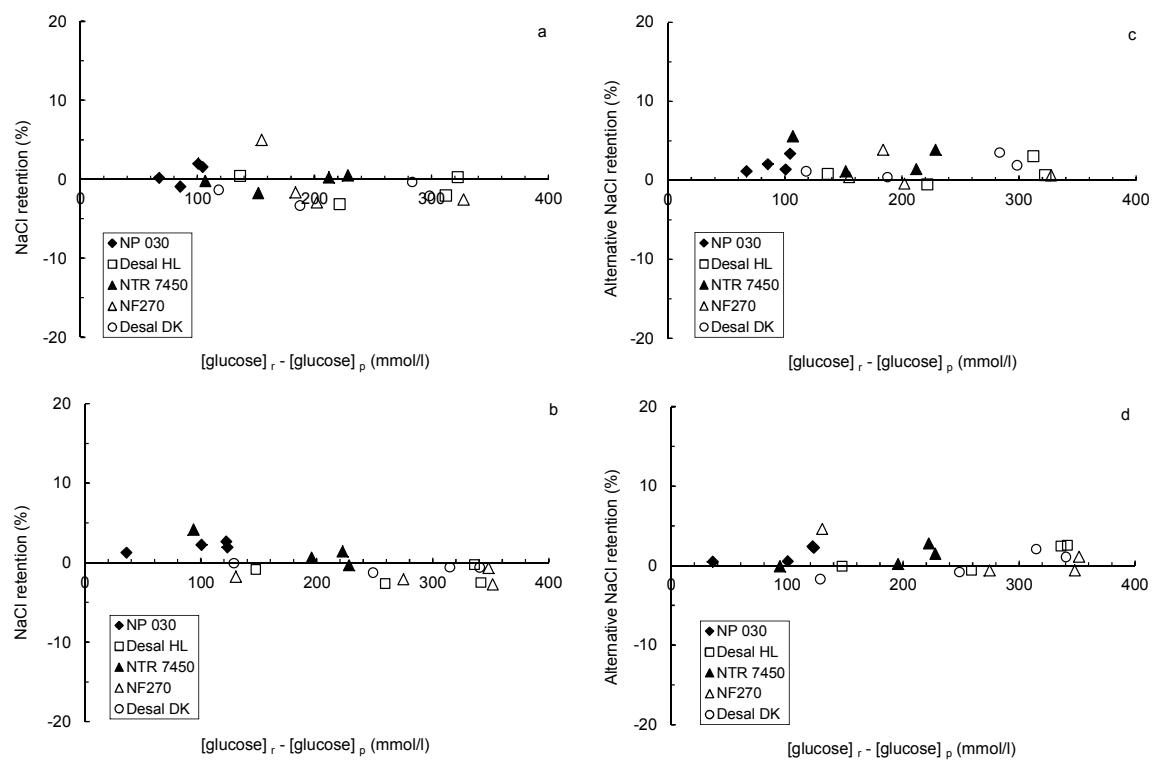

Figure 11: Observed $\mathrm{NaCl}$ retention as function of the difference in glucose concentration between retentate and permeate at room temperature, pressures between 5 and 25 bar and neutral $\mathrm{pH}$. Normal retention based on $\mathrm{NaCl}$ concentrations measured in retentate and concentrate and processing feed solutions containing $260 \mathrm{~g} . \mathrm{L}^{-1}$ sodium chloride and 80 g. $\mathrm{L}^{-1}$ glucose (top left, a), and $175 \mathrm{~g} . \mathrm{L}^{-1}$ sodium chloride and $80 \mathrm{~g} \cdot \mathrm{L}^{-1}$ glucose (bottom left, b). Alternative retentions based on $\mathrm{NaCl}$ in water only (excluding glucose, see equations 14 and 15) and processing feed solutions containing $260 \mathrm{~g} . \mathrm{L}^{-1}$ sodium chloride and $80 \mathrm{~g} . \mathrm{L}^{-1}$ glucose (top right, c), and $175 \mathrm{~g} . \mathrm{L}^{-1}$ sodium chloride and $80 \mathrm{~g} . \mathrm{L}^{-1}$ glucose (bottom right, d). 

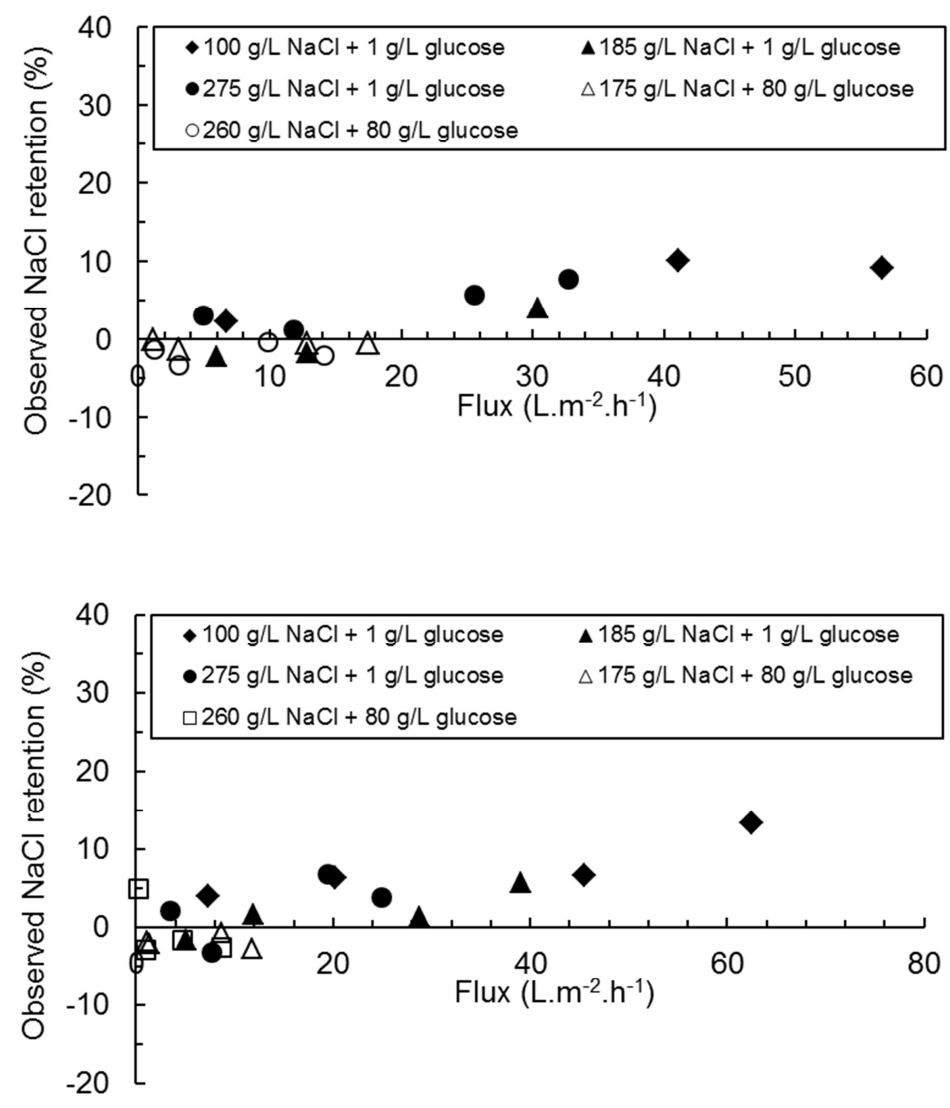

Figure 12: The effect of membrane flux on observed $\mathrm{NaCl}$ retention for Desal $\mathrm{DK}$ (top) and NF 270 (bottom) processing solutions containing 1 g. $\mathrm{L}^{-1}$ glucose or $80 \mathrm{~g} . \mathrm{L}^{-1}$ glucose and different $\mathrm{NaCl}$ concentrations.

\section{Conclusions}

In this study results from nanofiltration of aqueous solutions containing $\mathrm{NaCl}$ in concentrations between $1 \mathrm{~g} . \mathrm{L}^{-1}$ and $300 \mathrm{~g} \cdot \mathrm{L}^{-1}$ and glucose concentrations as high as 80 g. $\mathrm{L}^{-1}$ are reported using NF 270, NTR 7450, NP030, Desal 5 DK and Desal $5 \mathrm{HL}$ membranes. For single salt $\mathrm{NaCl}$ solutions with a $\mathrm{NaCl}$ concentration of $100 \mathrm{~g} \cdot \mathrm{L}^{-1}$ or higher, all membranes evaluated show $\mathrm{NaCl}$ retentions below $20 \%$. The glucose retention for solutions containing $1 \mathrm{~g} \cdot \mathrm{L}^{-1}$ glucose decreases strongly when the $\mathrm{NaCl}$ 
concentration is increased from $0 \mathrm{~g} \cdot \mathrm{L}^{-1}$ to $100 \mathrm{~g} \cdot \mathrm{L}^{-1}$, when compared at similar flux. A change in the pore radius at assumed constant glucose radius or alternatively a change in the ratio of glucose molecular radius over the membrane effective pore radius explains the obtained results. A further increase in $\mathrm{NaCl}$ concentration results in slight further reductions of the glucose retentions and consequently slightly higher mean pore radii. At very high glucose concentrations in the feed solution and $\mathrm{NaCl}$ concentrations in excess of $175 \mathrm{~g} \cdot \mathrm{L}^{-1}$, the $\mathrm{NaCl}$ retention is around 0 for all membranes evaluated, and only slightly affected by the difference in glucose concentration between retentate and permeate. The presence of glucose only has a minor salting-out effect on $\mathrm{NaCl}$, leading to slightly negative $\mathrm{NaCl}$ retentions for high glucose concentrations.

For mixed glucose and $\mathrm{NaCl}$ solutions containing $\mathrm{NaCl}$ concentrations higher than 90 $\mathrm{g} . \mathrm{L}^{-1}$, an increase in the glucose concentration from $1 \mathrm{~g} . \mathrm{L}^{-1}$ to $80 \mathrm{~g} \cdot \mathrm{L}^{-1}$ does not affect the glucose retention at the same flux for NF 270, Desal 5DK, Desal 5HL and NP 030. However, at the same operating pressure an increase in glucose concentration from 1 g. $\mathrm{L}^{-1}$ to $80 \mathrm{~g} . \mathrm{L}^{-1}$ results in significantly lower glucose retentions due to the lower flux at higher glucose concentrations. For solutions containing $1 \mathrm{~g} \cdot \mathrm{L}^{-1}$ glucose and $\mathrm{NaCl}$ concentrations of $100 \mathrm{~g} \cdot \mathrm{L}^{-1}$ and higher, the membrane flux has a significant influence on the $\mathrm{NaCl}$ retention. For all membranes evaluated mean pore radii and effective membrane thicknesses have been determined. Changes in the pore radii and effective diameters can be explained by hypothesis proposed in earlier studies. The obtained parameters can be used to facilitate the development of nanofiltration applications for desalination of concentrated glucose solutions in industry.

\section{Nomenclature}
$A_{k} \quad$ porosity of the membrane
$c_{i} \quad$ concentration of component $\mathrm{i}$ in the membrane $\mathrm{mol} \mathrm{m}^{-3}$
$C_{i, m} \quad$ concentration of component $\mathrm{i}$ on the feed side of the membrane $\mathrm{mol} \mathrm{m}^{-3}$ concentration of component $i$ on the permeate side of the
$C_{i, p} \quad$ membrane
$\mathrm{mol} \mathrm{m}{ }^{-3}$
$D_{\infty} \quad$ diffusivity of the solute
$\mathrm{m}^{2} \mathrm{~s}^{-1}$
$D_{i, \infty} \quad$ bulk diffusivity of solute $\mathrm{i}$
$\mathrm{m}^{2} \mathrm{~s}^{-1}$ 
$D_{i, p} \quad$ hindered diffusivity

$m^{2} s^{-1}$

$G \quad$ hydrodynamic enhanced lag coefficient

$J \quad$ volume flux

$m^{3} m^{-2} s^{-1}$

$j_{i} \quad$ flux of component i

$\mathrm{mol} \mathrm{m} \mathrm{m}^{-2} \mathrm{~s}^{-1}$

$J_{w} / \Delta P \quad$ pure water permeance

$\mathrm{m} \mathrm{s}^{-1} \mathrm{kPa}^{-1}$

$k \quad$ mass transfer constant

$K^{-1} \quad$ hydrodynamic enhanced drag coefficient

$K_{i, c} \quad$ hindrance factor for convection

$K_{i, d} \quad$ hindrance factor for diffusion

$P e_{m} \quad$ Peclet number

$R^{\prime} \mathrm{NaCl}$, alt alternative $\mathrm{NaCl}$ retention based on $x_{\mathrm{NaCl}, \mathrm{C}}$ and $x_{\mathrm{NaCl}, \mathrm{p}}$

$R_{\text {obs }} \quad$ observed rejection

$r_{p} \quad$ mean pore radius

m

$R_{\text {real }} \quad$ real rejection

$r_{s} \quad$ solute Stokes radius

$\mathrm{m}$

$x \quad$ distance normal to membrane

m

$x_{\mathrm{NaCl}, \mathrm{c}}$ weight fraction $\mathrm{NaCl}$ in concentrate excluding glucose

$x_{\mathrm{NaCl}, p}$ weight fraction $\mathrm{NaCl}$ in permeate excluding glucose

$W_{H 2 O, c} \quad$ weight water in concentrate

$\mathrm{kg}$

$W_{H 2 O, p} \quad$ weight water in permeate

$\mathrm{kg}$

$w_{\mathrm{NaCl}, \mathrm{C}}$ weight $\mathrm{NaCl}$ in concentrate

$\mathrm{kg}$

$w_{\mathrm{NaCl}, p}$ weight $\mathrm{NaCl}$ in permeate

$\mathrm{kg}$

$\Delta x \quad$ membrane thickness

m

$\Lambda$ ratio of solute to pore radius

$\mu \quad$ viscosity of solution

$\mathrm{kPa} \mathrm{s}$

$v \quad$ solute velocity

$\mathrm{m} \mathrm{s}^{-1}$

$\Phi \quad$ steric partition term 


\section{References}

[1] W.R. Bowen, A.W. Mohammad, N. Hilal, Characterization of nanofiltration membranes for predictive purposes- use of salts, uncharged solutes and atomic force microscopy, J. Membr. Sci. 126 (1997) 91-105.

[2] J. Schaep, C. Vandecasteele, A. W. Mohammad, W.R. Bowen, Modelling the retention of ionic components for different nanofiltration membranes, Sep. Purif. Technol. 22-23 (2001) 169-179.

[3] G. Hagmeyer, R. Gimbel, Modelling the salt rejection of nanofiltration membranes for ternary ion mixtures and for single salts at different $\mathrm{pH}$ values, Desalination 117 (1998) 247-256.

[4] W.R. Bowen, H. Mukhtar, Characterization and prediction of separation performance of nanofiltration membranes, J. Membr. Sci. 112 (1996) 263-274.

[5] Y. Garba, S. Taha, N. Gondrexon , G. Dorange, lon transport modelling through nanofiltration membranes, J. Membr. Sci. 160 (1999) 187-200.

[6] H.C. van der Horst, J.M.K. Timmer, T. Robbertsen, J. Leenders, Use of nanofiltration for concentration and demineralization in the dairy industry: model for mass transport, J. Membr. Sci. 104 (1995) 205-218.

[7] J. Straatsma, G. Bargeman, H.C. van der Horst, J.A. Wesselingh, Can nanofiltration be fully predicted by a model? J. Membr. Sci. 198 (2002) 273-284.

[8] T.R. Noordman, P. Vonk, V.H.J.T. Damen, R. Brul, S.H. Schaafsma, M. de Haas, J.A. Wesselingh, Rejection of phosphates by a $\mathrm{ZrO}_{2}$ ultrafiltration membrane, J. Membr. Sci. 135 (1997) 203-210.

[9] T.R. Noordman, High flux membrane filtration, Ph.D.thesis, University of Groningen, 1994.

[10] A.E. Yaroshchuk, Dielectric exclusion of ions from membranes, Adv. Coll. Interface Sci. 85 (2000) 193-230.

[11] A.E. Yaroshchuk, V. Ribitsch, The use of trace ions for advanced characterization of transport properties of NF membranes in electrolyte solutions: theoretical analysis, J. Membr. Sci. 201 (2002) 85-94.

[12] G. Bargeman , J.M. Vollenbroek, J. Straatsma, C.G.P.H. Schoën, R.M. Boom, Nanofiltration of multi-component feeds. Interactions between neutral and charged components and their effect on retention, J. Membr. Sci. 247 (2005) 1120. 
[13] A. Bouchoux, H. Roux-de Balmann, F. Lutin, Nanofiltration of glucose and sodium lactate solutions Variations of retentions between single- and mixedsolute solutions, J. Membr. Sci. 258 (2005) 123-132.

[14] E. Vellenga, G. Trägårdh, Nanofiltration of combined salt and sugar solutions: coupling between retentions, Desalination 120 (1998) 211-220.

[15] B. Cuartas-Uribe, M.C. Vincent-Vela, S. Álvarez-Blanco, M.I. Alcaina-Miranda, E. Soriano-Costa, Nanofiltration of sweet whey and prediction of lactose retention as a function of permeate flux using the Kedem-Spiegler and Donnan Steric Partitioning models, Sep. Pur. Techn. 56 (2007), 38-46.

[16] M. Nilsson, G. Trägårdh, K. Östergren, The influence of $\mathrm{pH}$, salt and temperature on nanofiltration performance, J. Membr. Sci. 312 (2008), 97-106.

[17] S. Bouranene, A. Szymczyk, P. Fievet, A. Vidonne, Effects of salts on the retention of polyethyleneglycol by a nanofiltration membrane, Desalination 240 (2009), 94-98.

[18] M. Dalwani, N.E. Benes, G. Bargeman, D. Stamatialis, M. Wessling, A method for characterizing membranes during nanofiltration at extreme $\mathrm{pH}, \mathrm{J}$. Membr. Sci. 363 (2010) 188-194.

[19] M. Dalwani, N.E. Benes, G. Bargeman, D. Stamatialis, M. Wessling, Effect of pH on the performance of polyamide/polyacrylonitrile based thin film composite membranes, J. Membr. Sci. 372 (2011) 228-238.

[20] M. Dalwani, G. Bargeman, S. Hosseiny, M. Boerrigter, M. Wessling, N. Benes, Sulfonated poly (ether ether ketone) based composite membranes for nanofiltration of acidic and alkaline media, J. Membr. Sci. 381 (2011) 81-89.

[21] S. Bouranene, A. Szymczyk, P. Fievet, A. Vidonne, Influence of inorganic electrolytes on the retention of polyethyleneglycol by a nanofiltration ceramic membrane, J. Membr. Sci. 290 (2007) 216-221.

[22] A. Escoda, P. Fievet, S. Lakard, A. Szymczyk, S. Déon, Influence of salts on the rejection of polyethyleneglycol by an NF organic membrane: Pore swelling and salting-out effects, J. Membr. Sci. 347 (2010), 174-182.

[23] V. Boy, H. Roux-de Balmann, S. Galier, Relationship between volumetric properties and mass transfer through NF membrane for saccharide/electrolyte systems, J. Membr. Sci. 390-391 (2012), 254-262.

[24] J. Luo and Y. Wan, Effect of highly concentrated salt on retention of organic solutes by nanofiltration polymeric membranes, J. Membr. Sci. 372 (2011) 145153. 
[25] E. Sjoman, M. Manttari, M. Nystrom, H. Koivikko, H. Heikkil, Separation of xylose from glucose by nanofiltration from concentrated monosaccharide solutions, J. Membr. Sci. 292 (2007) 106-115.

[26] G. Bargeman, M. Steensma, A. ten Kate, J.B. Westerink, R.L.M. Demmer, H. Bakkenes and C.F.M. Manuhutu, Nanofiltration as energy-efficient solution for sulfate waste in vacuum salt production, Desalination 245 (2009) 460-468.

[27] M. Kyburz and G.W. Meindersma, Nanofiltration in the chemical processing industry, in A.I. Schafer, A.G. Fane, T.D. Waite (Eds), Nanofiltration - Principles and Applications, Elsevier Ltd., Oxford, UK, 2005.

[28] G. Bargeman, M. Timmer, C. van der Horst, Nanofiltration in the food industry, in A.I. Schafer, A.G. Fane, T.D. Waite (Eds), Nanofiltration - Principles and Applications, Elsevier Ltd., Oxford, UK, 2005.

[29] M. Nilsson, G. Trägårdh, K. Östergren, The influence of sodium chloride on mass transfer in a polyamide nanofiltration membrane at elevated temperatures, J. Membr. Sci. 280 (2006) 928-936.

[30] M. Mänttäri, A. Pihlajamäki, E. Kaipainen, M. Nyström , Effect of temperature and membrane pre-treatment by pressure on the filtration properties of nanofiltration membranes, Desalination 145 (2002) 81-86.

[31] J. Tanninen, M. Mänttäri, M. Nyström, Effect of salt mixture concentration on fractionation with NF membranes, J. Membr. Sci. 283 (2006) 57-64.

[32] H. Matsumoto, Y.-C. Chen, R. Yamamoto, Y. Konosu, M. Minagawa, A. Tanioka, Membrane potentials across nanofiltration membranes: effect of nanoscaled cavity structure, J. of Molec. Struct. 739 (2005) 99-104.

[33] B. Cuartas-Uribe, A. Iborra-Clar, A. Bes-Piá, J.A. Mendoza-Roca, M.V. GalianaAleixandre, M.I. Iborra-Clar, Nanofiltration of a simulated tannery wastewater: influence of chlorides concentration, Desalination 191 (2006) 132-136.

[34] W.R Bowen and A.W. Mohammad, Characterization and prediction of nanofiltration membrane performance- a general assessment, Trans IChemE, Vol 76, Part A, November 1998, 885-893.

[35] S. Koter, Determination of the parameters of the Spiegler-Kedem-Katchalsky model for nanofiltration of single electrolyte solutions, Desalination 198 (2006) 335-345.

[36] S. Bandini, D. Vezzani, Nanofiltration modelling: the role of dielectric exclusion in membrane characterization, Chem. Eng. Sci. 58 (2003) 3303-3326. 
[37] K. Kosutic, D. Dolar, B. Kunst, On experimental parameters characterizing the reverse osmosis and nanofiltration membranes' active layer, J. Membr. Sci. 282 (2006) 109-114.

[38] A.W. Mohammad, R. Kadir Basha and C.P. Leo, Nanofiltration of glucose solutions containing salts: Effects of membrane characteristics, organic component and salts on retention, Journal of Food Engineering 97 (2010) 510518.

[39] K. Boussu, B. Van der Bruggen, A. Volodin, C. Van Haesendonck, J.A. Delcour, P. Van der Meeren, C. Vandecasteele, Characterization of commercial nanofiltration membranes and comparison with self-made polyethersulphone membranes, Desalination 191 (2006) 245-253.

[40] M. Mänttäri, A. Pihlajamäki, M. Nyström, Effect of pH on hydrophilicity and charge and their effect on the filtration efficiency of NF membranes at different pH, J. Membr. Sci. 280 (2006) 311-320.

[41] J. Schaep, C. VandeCasteele, A.W. Mohammad, W.R. Bowen, Analysis of the salt retention of nanofiltration membranes using Donnan-steric portioning pore model, Sep. Sci. Technol. 34 (1999) 3009-3030.

[42] M. Mänttäri, K. Viitikko, M. Nyström, Nanofiltration of biologically treated effluents from de pulp and paper industry, J. Membr. Sci. 272 (2006) 152-160.

[43] C. Fersi, L. Gzara, M. Dhahbi, Treatment of textile effluents by membrane technologies, Desalination 185 (2005) 399-409.

[44] K. Boussu, Y. Zhang, J. Cocquyt, P. Van der Meeren, A. Volodin, C. Van Haesendonck, J.A. Martens, B. van der Bruggen, Characterization of polymeric nanofiltration membranes for systematic analysis of membrane performance, J. Membr. Sci. 278 (2006) 418-427.

[45] C.Y. Tang, Y-N. Kwon, J. O. Leckie, Fouling of reverse osmosis and nanofiltration membranes by humic acid-Effects of solution composition and hydrodynamic conditions, J. Membr. Sci. 290 (2007), 86-94.

[46] M. Nyström, S. Butylina, S. Platt, NF retention and critical flux of small hydrophilic/hydrophobic molecules, Membrane Technology 10 (2004) 5-8.

[47] K. Hu and J.M. Dickson, Nanofiltration membrane performance on fluoride removal from water, J. Membr. Sci. 279 (2006) 529-538.

[48] J. Shirley, S. Mandale, V. Kochkodan, Influence of solute concentration and dipolemoment on the retention of uncharged molecules with nanofiltration, Desalination 344 (2014) 116-122. 
[49] W.R. Bowen, J.S. Welfoot, Modelling of membrane nanofiltration-pore size distribution effects, Chem. Eng. Sci. 57 (2002) 1393-1407.

[50] J. Schaep, B. Van der Bruggen, C. Vandecasteele, D. Wilms, Influence of ion size and charge in nanofiltration, Sep. Pur. Techn. 14 (1998) 155-162.

[51] M.D. Afonso, Surface charge on loose nanofiltration membranes, Desalination 191 (2006) 262-272.

[52] W.R. Bowen, J.S. Welfoot and P.M. Williams, Linearized transport model for Nanofiltration: Development and assessment, AIChE J. 48 (4), (2002), 760-773.

[53] J.M.K. Timmer, M.P.J. Speelmans, F. Donkers, H.C. van der Horst, Mass transfer of amino acids through nanofiltration membranes, in: A.J.B. Kemperman, G.H. Koops (Eds.), Progress in Membrane Science and Technology, Book of abstracts, Euromembrane'97, Enschede, The Nederlands, 22-27 June 1997, Dinkeldruk Oldenzaal, The Nederlands, p. 459.

[54] J.M.K. Timmer, Properties of nanofiltration membranes model development and industrial application, Ph.D. thesis, Technical Unisversity of Eindhoven, Eindhoven, The Nederlands, 2001.

[55] X.-L. Wang, T. Tsuru, M. Togoh, S.-I. Nakao, S. Kimura, Evaluation of pore structure and electrical properties of nanofiltration membranes, J. Chem. Eng. Jpn. 28 (1995), 186-192.

[56] W.M. Haynes (ed. in chief), Concentrative properties of aqueous solutions: Density, refractive index, freezing point depression, and viscosity, Section 5, CRC Handbook of Chemistry and Physics, 95 ${ }^{\text {th }}$ Edition, 2014-2015.

[57] W. Ogieglo, H. van der Werf, K. Tempelman, H. Wormeester, M. Wessling, A. Nijmeijer, N.E. Benes, n-Hexane induced swelling of thin PDMS films under nonequilibrium nanofiltration permeation conditions, resolved by spectroscopic ellipsometry, J. Membr. Sci. 437 (2013) 313-323. 


\section{Chapter 4}

Nanofiltration as energy-efficient solution for sulfate waste in vacuum salt production

This chapter has been published as:

G. Bargeman, M. Steensma, A. ten Kate, J.B. Westerink, R.L.M. Demmer, H. Bakkenes and C.F.H. Manuhutu, Desalination 245 (2009), 460-468. 


\begin{abstract}
In vacuum salt production sulfate is an important impurity, but it is also used to remove other cationic impurities from the raw brine. Removal of excess sulfate is currently done by purging salt crystallizer mother liquor from the brine plant, or crystallizing sodium sulfate through evaporative or cooling crystallization. The use of nanofiltration for the production of brines supersaturated in sodium sulfate is a technically feasible and attractive alternative. Crystallization of sodium sulfate in the membrane modules can be avoided by the presence of a primary nucleation inhibitor in the feed to the nanofiltration unit. Sodium sulfate crystallization can be induced in a separate crystallizer outside of the membrane unit by addition of crystal seeds. NF270 is a suitable membrane for this application and is preferred over Desal DK, Desal DL, TS-80 and MPF-34. Chloride and bromide retentions are negative and they are a function of the difference in sulfate concentration between concentrate and permeate. Carbonate retentions are linearly dependent on sulfate retentions. Calcium retention for NF270 is in excess of $95 \%$ and proven to be stable during 1200 hours of continuous on-site pilot plant operation. The same applies for the potassium retention albeit at a lower level of $10 \%$.
\end{abstract}




\section{Introduction}

During the production of vacuum salt $(\mathrm{NaCl})$ in conventional evaporative crystallization, sulfate is an important impurity. In the process, the sulfate concentration in the crystalline $\mathrm{NaCl}$ produced remains very low and the sulfate concentration in the mother liquor increases to the point of saturation. The mother liquor thus produced can sometimes be recycled to the brine purification or is (partly) discharged into the sea. In other cases, environmental permits may require crystallization of solid sodium sulfate, either by a steam-powered heating/evaporation process or by cooling crystallization. Both processes consume a lot of energy. Development of less energy consuming alternatives is therefore desired from economical and ecological perspective.

This paper describes the development of a nanofiltration (NF) process for mother liquor saturated in $\mathrm{NaCl}$ and $\mathrm{Na}_{2} \mathrm{SO}_{4}$ that produces a permeate practically saturated in $\mathrm{NaCl}$ and lean in sulfate, and a retentate practically saturated in $\mathrm{NaCl}$ and supersaturated in $\mathrm{Na}_{2} \mathrm{SO}_{4}$. After the nanofiltration step, solid sodium sulfate can be crystallized from the retentate without additional energy input. The intended application of this nanofiltration operation in a salt plant is illustrated in Fig. 1.

Separation of sulfates from chlorides is a well known application of nanofiltration $[1,2]$ and is commercially applied for concentration of depleted brine in chlor/alkali production [3] and production of seawater with a low sulfate content used for injection in off-shore oil and gas production [3]. However, operation is always maintained at concentrations below sulfate saturation to avoid formation of crystals in the membrane modules. Although it is known that for sparingly soluble salts operation in excess of saturation can be maintained because of a significant metastable region, this is normally not the case for readily soluble salts like sodium sulfate [4]. In this work, we have successfully controlled sodium sulfate supersaturation far outside the normal metastable region, by applying a primary nucleation inhibitor. In the following sections we will focus on the development of the nanofiltration part of the process. Additional information can be found in a filed patent application [5]. 


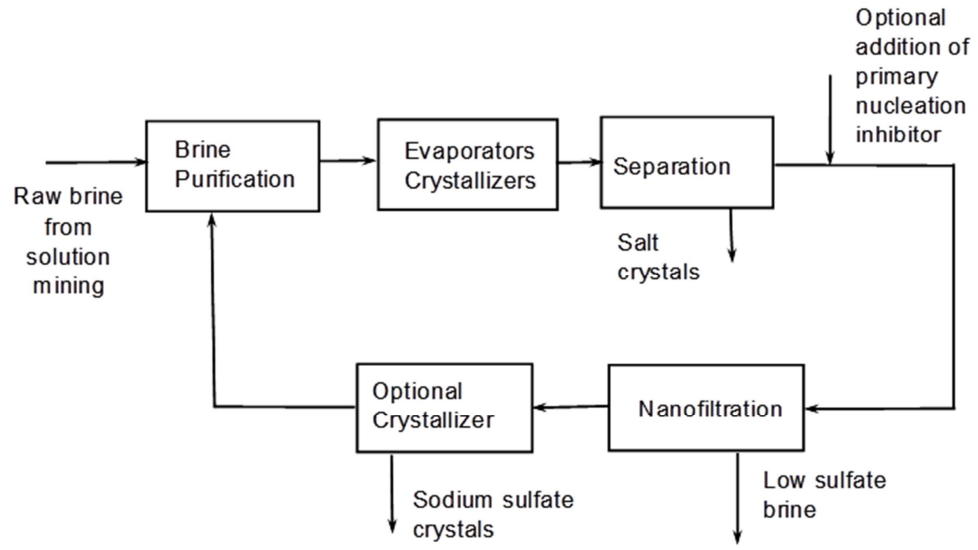

Figure 1: Nanofiltration of $\mathrm{NaCl}$ crystallizer mother liquor containing a primary nucleation inhibitor for production of a concentrate supersaturated in sodium sulfate. Schematic representation of implementation of the nanofiltration technology in a salt plant.

\section{Experimental}

Proof of principle experiments were done on lab-scale using a DSS Labstak M20 unit. This unit contains flat sheet membranes with a surface area of $0.036 \mathrm{~m}^{2}$ per membrane type. To come to a first membrane selection Desal DK and Desal DL (GE/Osmonics), NF270 (Dow FilmTec), TS-80 (TriSep) and MPF-34 (Koch) were evaluated using mother liquor from a commercial salt plant as feedstock. Experiments were initially performed in batch-wise operation purging the permeates from the unit, while recycling the concentrate to the feed vessel. The best performing membranes from these tests were used in feed and bleed mode feeding mother liquor to the installation and purging permeates and part of the concentrate from the unit, thus adjusting the concentration factor used in the installation. Lab-scale experiments were performed at transmembrane pressures between 30 bar and 55 bar, temperatures between $30^{\circ} \mathrm{C}$ and $50^{\circ} \mathrm{C}$, concentration factors up to $\mathrm{CF}=1.6$ and a cross-flow rate of $600 \mathrm{l} / \mathrm{h}$. The mother liquor contained 275-285 g/l NaCl and 550-600 mmol// sulfate. For most experiments with Desal DK, Desal DL, NF270 and TS-80 the pH of the mother liquor was adjusted to $\mathrm{pH}<11.0$. For nanofiltration with MPF-34 operation was maintained at $\mathrm{pH}=12.3$. To avoid crystallization in the membrane installation at supersaturated sodium sulfate 
conditions, $100 \mathrm{ppm}$ of a primary nucleation inhibitor (sometimes called a crystal growth inhibitor or CGI) was added to the mother liquor prior to the nanofiltration process. Examples of crystal growth inhibitors can be found in [5]. Addition is not required if sufficient amounts of these primary nucleation inhibitors are present in the mother liquor.

Following lab-scale experiments, on-site pilot plant experiments at a commercial salt production plant were performed. During these on-site experiments at least $100 \mathrm{ppm}$ CGI was present in the feed to membranes as well. The nanofiltration pilot unit (see Fig. 2) was operated in continuous feed and bleed mode using mother liquor brine from the salt plant as feed. Desal 5DK and NF270 modules were placed in separate 4 inch pressure housings operated in parallel for further membrane selection. Both pressure housings had their own concentrate recirculation loop and feed, permeate and concentrate lines. In this part of the trial 4 different membrane modules per type were evaluated (module sets 1 to 4 ) in different tests. Pressures, temperatures and concentration factors were varied between $29-37$ bar, $35-40^{\circ} \mathrm{C}$ and $1.2-1.5$ and a crossflow of around $3.0 \mathrm{~m}^{3} / \mathrm{h}$ was maintained over both modules. The $\mathrm{pH}$ of the mother liquor supplied to the nanofiltration unit ranged between 10.7 and 11.0, except for the occurrence of several excursions up to $\mathrm{pH}=12.4$ for operation with module sets $1-3$.

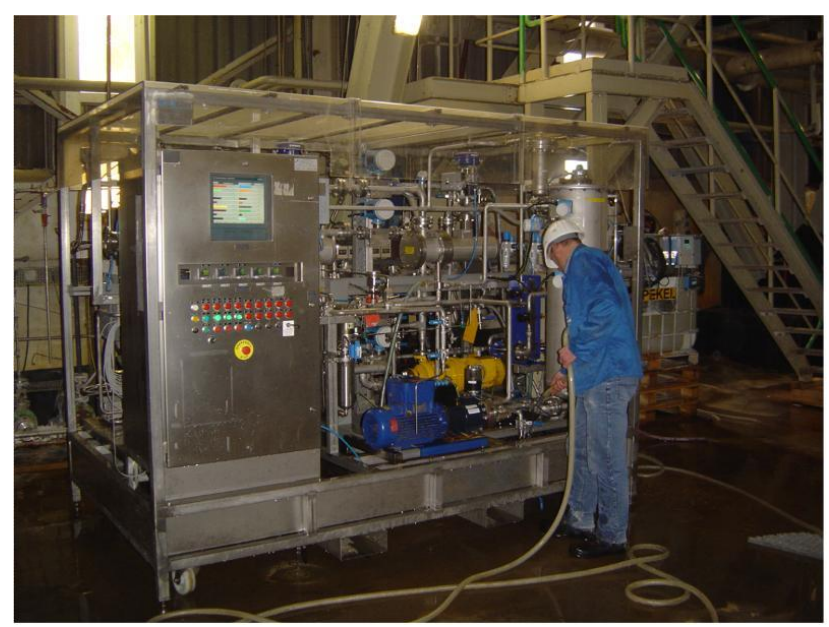

Figure 2: Pilot installation for on-site nanofiltration pilot trials. 
In the second part of this on-site pilot trial, NF270 was tested in two-stage operation mode (with two pressure housings, each containing one module, in series), with each stage having its own recirculation loop and concentration factor. In total 5 NF270 modules per stage were evaluated (module sets 5 to 9 ) in different experiments. During two-stage operation, the effect of different operating parameters was evaluated and input for the design of a commercial installation and an economical evaluation was gathered. During this long-term two-stage mode testing trans-membrane pressures in the range of 29-37 bar were used with temperatures ranging between $32^{\circ} \mathrm{C}$ and $59^{\circ} \mathrm{C}$ and concentration factors between 1.2 and 1.4. Cross-flow rates to the membrane module inlets were $3.0-3.4 \mathrm{~m}^{3} / \mathrm{h}$. The $\mathrm{pH}$ of the mother liquor sent to the nanofiltration unit ranged between 9.5-10.7.

\section{Results and discussion}

During batch-wise lab-scale trials NF270 and Desal DK showed better performance than the other membranes evaluated. Especially the sulfate retention of these membranes was high (almost 98\%) and met the sulfate retention target of $90 \%$, unlike the other membranes (see Table 1).

Table 1: Sulfate retention of nanofiltration membranes during processing of mother liquor $(\mathrm{pH}=12.3)$ saturated in sodium chloride and sodium sulfate at $\mathrm{CF}=1.0, \mathrm{~T}=30^{\circ} \mathrm{C}$ and $\mathrm{P}=35$ bar for MPF-34 and $\mathrm{CF}=1.0, \mathrm{~T}=32^{\circ} \mathrm{C}$ and $\mathrm{P}=54$ bar for the other membranes.

\begin{tabular}{l|c}
\hline Membrane type & Sulfate retention (\%) \\
\hline Desal DK & 98 \\
Desal DL & $62-78$ \\
NF270 & 98 \\
TS-80 & $73-76$ \\
MPF-34 & 89 \\
\hline
\end{tabular}

Lab-scale experiments in continuous feed and bleed mode with NF270 and Desal DK at a concentration factor of $\mathrm{CF}=1.5$ were maintained during 6 hours. During that period a concentrate supersaturated in sodium sulfate (see Fig. 3) was produced with concentrations as high as $800 \mathrm{mmol} / \mathrm{l}$ in combination with sodium chloride 
concentrations of $282 \mathrm{~g} / \mathrm{l}$. Crystallization of sodium sulfate or sodium chloride in the membrane module did not occur as a consequence of the presence of the CGI. Addition of sodium sulfate seeds to the concentrate in a separate crystallizer resulted in crystallization of sodium sulfate as indicated by a reduction in sulfate concentration from $800 \mathrm{mmol} / \mathrm{l}$ to below $600 \mathrm{mmol} / \mathrm{l}$. The stable flux for NF270 $\left(7 \mathrm{~kg} / \mathrm{m}^{2} . \mathrm{h}\right.$ at 35 bar transmembrane pressure) was higher than for Desal DK $\left(2.5 \mathrm{~kg} / \mathrm{m}^{2} . \mathrm{h}\right)$. Operation at a transmembrane pressure of 50 bar resulted in considerably higher fluxes of $16.6 \mathrm{~kg} / \mathrm{m}^{2} . \mathrm{h}$ and $9.8 \mathrm{~kg} / \mathrm{m}^{2}$.h for NF270 and Desal DK, respectively. This steep increase in flux is caused by the high osmotic pressure differences between concentrate and permeate, counteracting the trans-membrane pressure.

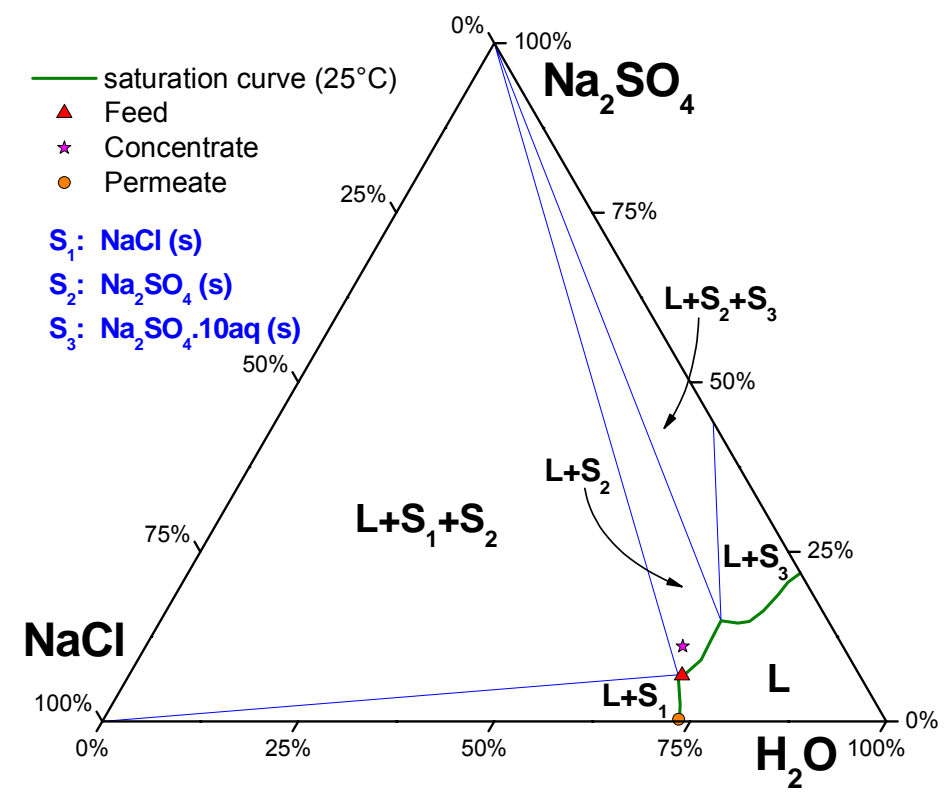

Figure 3: $\mathrm{NaCl}, \mathrm{Na}_{2} \mathrm{SO}_{4}$ and $\mathrm{H}_{2} \mathrm{O}$ composition (\%w) of feed, permeate and concentrate. 


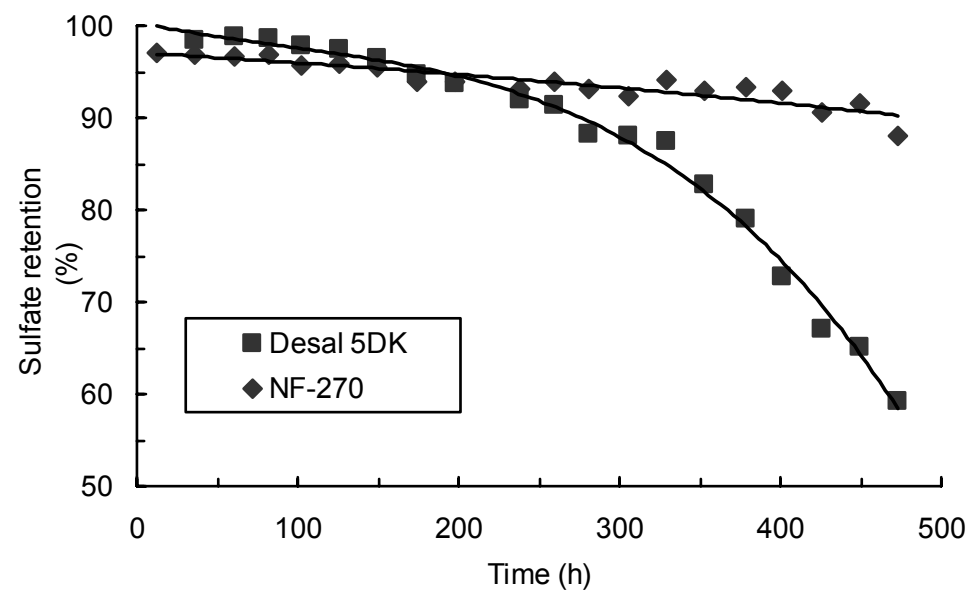

Figure 4: $\quad$ Sulfate retention as function of operation time for NF270 and Desal DK (set 4) during processing of mother liquor at $\mathrm{CF}=1.2-1.4$, a pressure of 32 bar until $315 \mathrm{~h}$ and 37 bar after $315 \mathrm{~h}$, a temperature between $35^{\circ} \mathrm{C}$ and $40^{\circ} \mathrm{C}$, and $\mathrm{a} \mathrm{pH}$ of the feed between 10.7 and 11.0

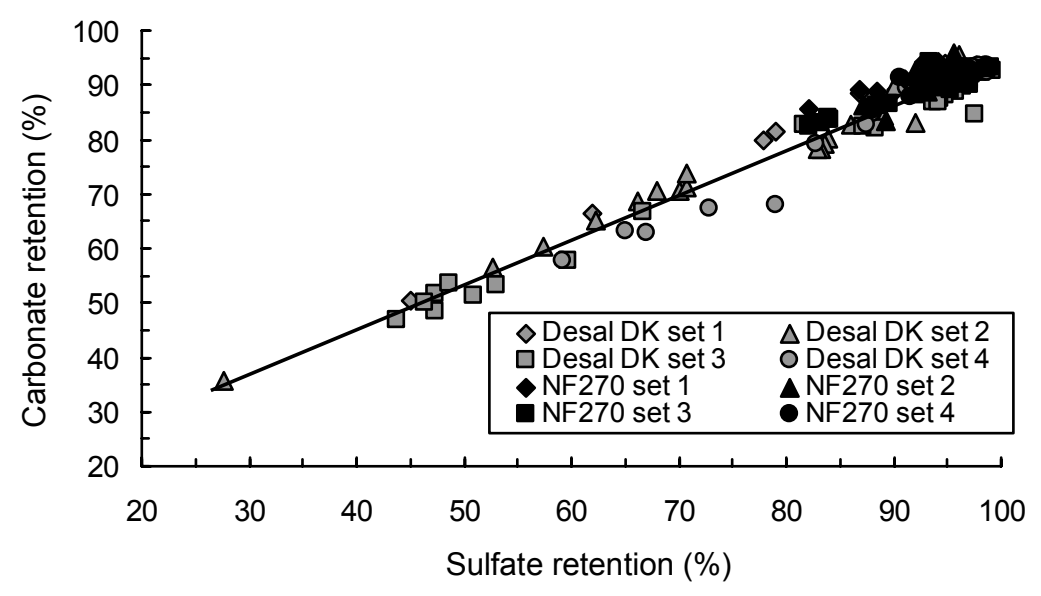

Figure 5: Carbonate retention for Desal DK and NF270 (sets 1-4) as function of the sulfate retention during processing of salt crystallizer mother liquor at $\mathrm{pH}=10.7-11.0$. 
During continuous on-site pilot trials processing mother liquor with a $\mathrm{pH}$ between 10.7 and 11.0 NF270 showed considerably better sulfate retention stability than Desal DK (see Fig. 4). For Desal DK the retention dropped from $98 \%$ to below $60 \%$ within 500 hours. For NF270 retention dropped from $97 \%$ to values in excess of $90 \%$ in the same period. Furthermore, with other membrane sets $\mathrm{pH}$ excursions occurred occasionally. This affected the performance of Desal DK to a larger extent. On the basis of this pilot scale membrane selection NF270 is considered to be more suitable for this application than Desal DK, in line with lab-scale results. NF270 not only showed a better pH stability and better sulfate retention stability than Desal DK, but a higher flux as well, while the initial sulfate retentions were about the same.

The carbonate (analyzed as a combination of carbonate and bi-carbonate) retention for Desal DK and NF270 is linearly dependent on the sulfate retention (see Fig. 5). This is not surprising since at the $\mathrm{pH}$ between 10.7 and 11.0 the fraction of bi-carbonate is limited, since carbonate has a pKa of 10.3 [6]. This implies that when the membrane performance for sulfate retention deteriorates carbonate retention reduces as well.

Chloride (see Fig. 6) and bromide (not shown) retentions for NF270 and Desal DK were negative, meaning that the concentrations of chloride and bromide in the permeate were higher than those in the retentate. These retentions can be described as a function of the difference in sulfate concentrations in concentrate and permeate (as illustrated in Fig. 6 for the chloride retention). For nanofiltration of brines practically saturated in $\mathrm{NaCl}$ and undersaturated in sodium sulfate using an unspecified membrane, Samhaber and Schwaiger [7] have related chloride retentions to the sulfate concentration in the feed. However, for operation with a constant sulfate concentration in the feed in this study, clear increases in chloride retention were found when the transmission of sulfate through the membrane increased. A relation between chloride (and bromide) retention with the difference in sulfate concentration in concentrate and permeate therefore gives a better description.

It is remarkable that the relations found for carbonate and chloride retention are similar for Desal DK and NF270. Furthermore, based on extrapolation of the obtained relation for NF270 and Desal DK, a chloride retention of 3\% would be expected for a brine saturated in $\mathrm{NaCl}$ with equal sulfate concentrations in the concentrate and permeate or without sulfate at all. This seems to be in line with extrapolated retention results for 
NF270 and Desal DK as reported by Tanninen et al. [8] and our own (yet unpublished) results for nanofiltration of single salt solutions containing around $300 \mathrm{~g} / \mathrm{l} \mathrm{NaCl}$. Conversion of the results published by Samhaber and Schwaiger [7] for a brine containing $180 \mathrm{~g} / \mathrm{l}$ chloride $(297 \mathrm{~g} / \mathrm{l} \mathrm{NaCl})$, assuming concentration factors close to $\mathrm{CF}=1$ and taking sulfate retentions at least equal to $98 \%$ as reported in that study, leads to chloride retentions in line with the results obtained in this study (see Fig. 7).

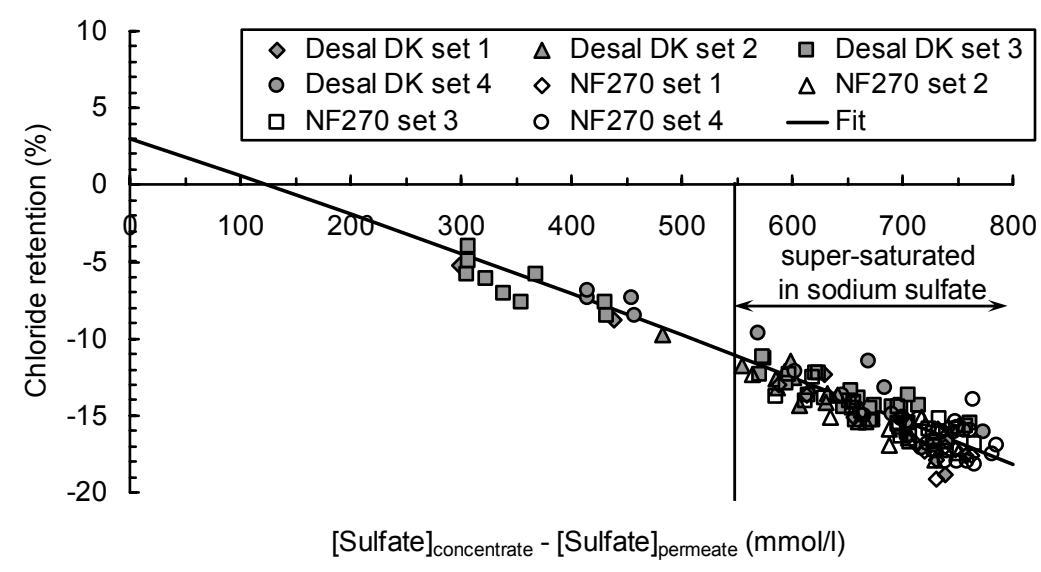

Figure 6: Chloride retention as function of the difference in sulfate concentration in concentrate and permeate during nanofiltration of mother liquor saturated in sodium chloride and sodium sulfate. 


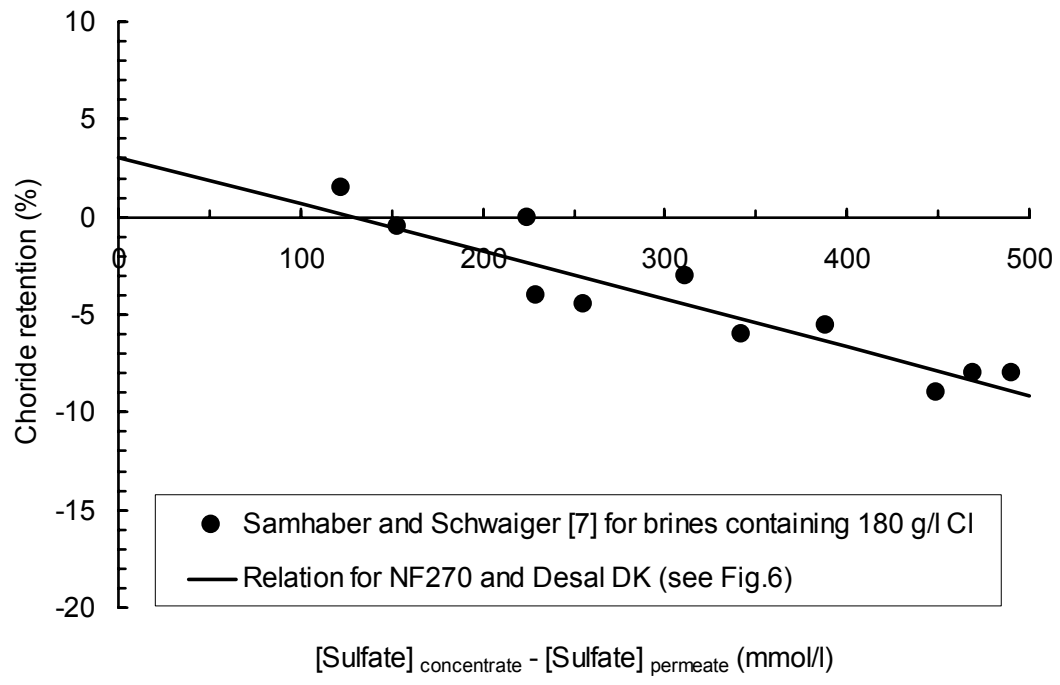

Figure 7: Chloride retentions obtained by Samhaber and Schwaiger [7] as function of the difference in sulfate concentration in concentrate and permeate for an unspecified nanofiltration membrane processing brines containing 180 $\mathrm{g} / \mathrm{l}$ chloride. Comparison with the relation obtained for NF270 and Desal DK.

In two stage operation with NF270 modules (set 6) in both stages at an overall concentration factor of $C F=1.3-1.4$, stable fluxes of $11 \mathrm{~kg} / \mathrm{m}^{2} . \mathrm{h}$ and $6 \mathrm{~kg} / \mathrm{m}^{2} . \mathrm{h}$ were obtained at 33.5 bar and 32 bar for stage 1 and stage 2 , respectively, and temperatures around $40^{\circ} \mathrm{C}$ (see Fig. 8). Increasing the pressures to 37 bar and 35 bar in stage 1 and 2 , resulted in stable fluxes of $14 \mathrm{~kg} / \mathrm{m}^{2} . \mathrm{h}$ and $7.5 \mathrm{~kg} / \mathrm{m}^{2} . \mathrm{h}$, respectively. These relatively steep increases in flux are caused by the high difference in osmotic pressure between retentate and permeate. High initial retentions for sulfate were obtained $(97 \%$ and $95 \%$ in stage 1 and 2, respectively). Although the sulfate retention reduced during the trial (see Fig. 9), it remained in excess of $90 \%$. Several reasons for the reduction of the sulfate retention were identified. Based on these insights the sulfate retention drop with time will be less severe in commercial operation. 


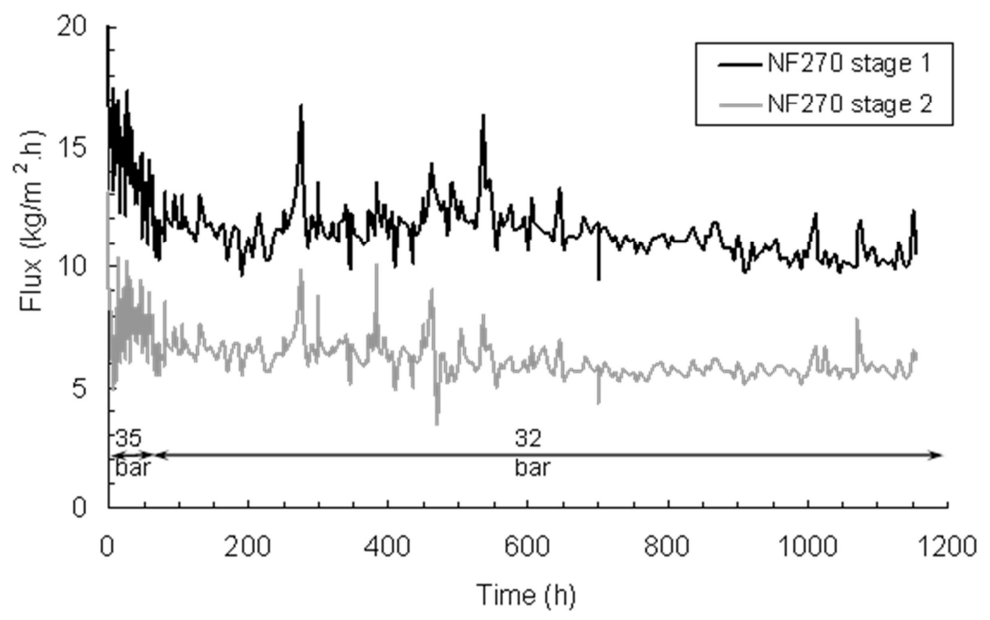

Figure 8: $\quad$ Flux for NF270 (module set 6) during two stage operation processing mother liquor at an overall concentration factor of $\mathrm{CF}=1.3-1.4$ and temperatures around $40^{\circ} \mathrm{C}$ producing a concentrate supersaturated in sodium sulfate.

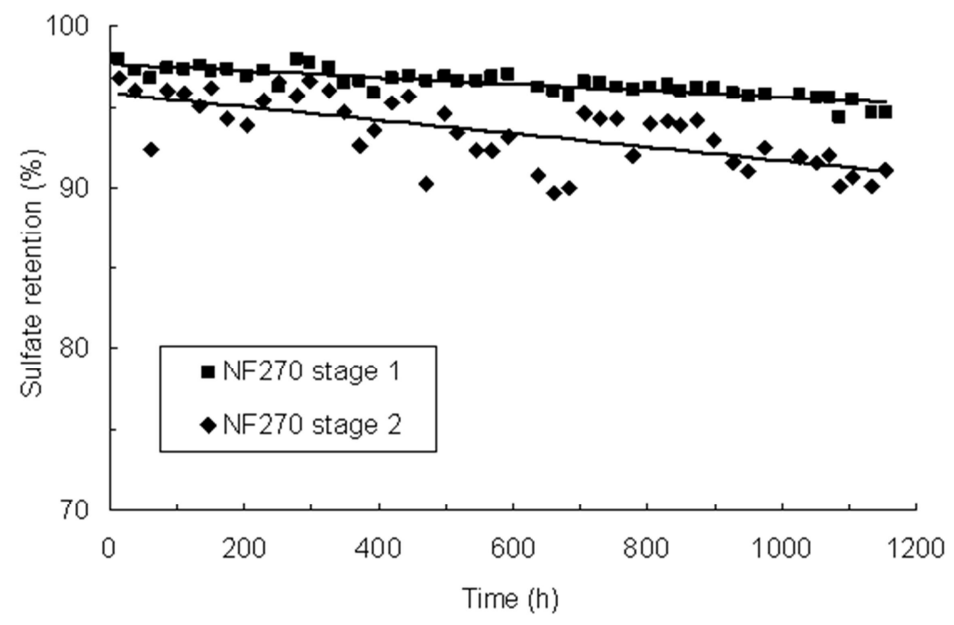

Figure 9: $\quad$ Sulfate retention for NF270 (module set 6) during two stage operation processing mother liquor at an overall concentration factor of $\mathrm{CF}=1.3-1.4$ and temperatures around $40^{\circ} \mathrm{C}$ producing a concentrate supersaturated in sodium sulfate. 
Retentions for calcium potassium, chloride and bromide were approximately 95\%, 10\%, $-15 \%$ and $-25 \%$ (see Fig. 10) and quite stable during the entire operating period. Differences in retentions in stage 1 and 2 were limited.

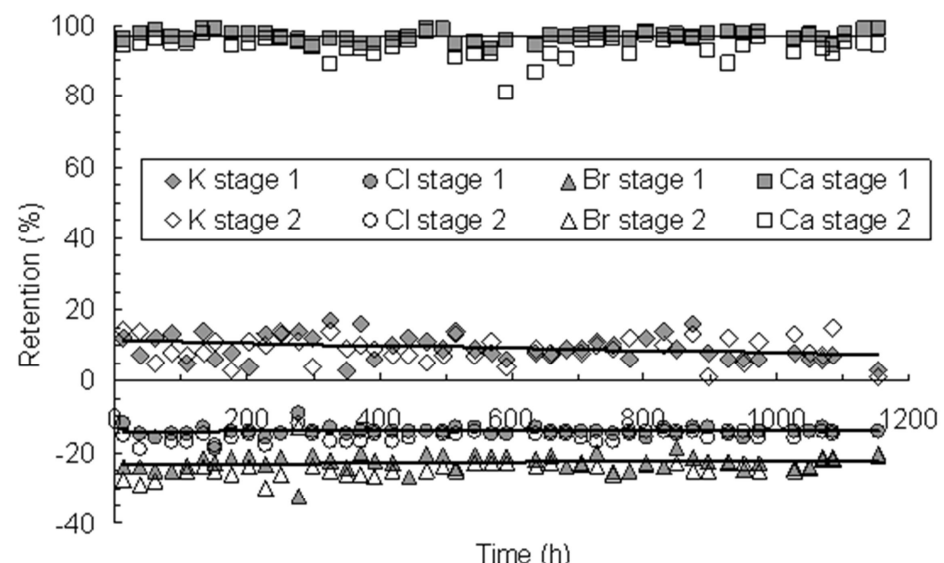

Figure 10: Calcium, potassium, chloride and bromide retention for NF270 (set 6) during two stage operation processing mother liquor at an overall concentration factor of $\mathrm{CF}=1.3-1.4$ producing concentrate supersaturated in sodium sulfate.

The trials have shown that concentration of mother liquor from a salt production plant with nanofiltration to produce a concentrate (retentate) supersaturated in $\mathrm{Na}_{2} \mathrm{SO}_{4}$ and practically saturated in $\mathrm{NaCl}$ is technically and economically feasible. Operation was maintained successfully during 1.5 months of continuous on-site operation at a concentration factor of $\mathrm{CF}=1.3-1.4$, processing mother liquor with a $\mathrm{pH}=10$. Sulfate concentrations could thus be increased from $0.55 \mathrm{M}$ in the mother liquor to $0.80 \mathrm{M}$ in the retentate without the occurrence of crystallization in the membrane modules. After that, sodium sulfate was crystallized successfully from the retentate in a separate pilot crystallizer. Several nanofiltration membranes are considered to be suitable for the application, but based on the experiments NF270 is considered to be the most suitable. 


\section{Conclusions}

The use of nanofiltration for the production of brines supersaturated in sodium sulfate is a technically feasible and attractive alternative. Crystallization of sodium sulfate in the membrane modules can be avoided by the presence of a primary nucleation inhibitor in the feed to the nanofiltration unit. Sodium sulfate crystallization can be induced in a separate crystallizer outside of the membrane unit by addition of crystal seeds. NF270 is a suitable membrane for this application and is preferred over Desal DK, Desal DL, TS-80 and MPF-34. Chloride and bromide retentions are negative and they are a function of the difference in sulfate concentration between concentrate and permeate. Carbonate retentions are linearly dependent on sulfate retentions. Calcium retention for NF270 is in excess of $95 \%$ and proven to be stable during 1200 hours of continuous onsite pilot plant operation. The same applies for the potassium retention albeit at a lower level of $10 \%$.

\section{Acknowledgements}

We want to thank Mateo Mayer, Maarten Schutyser, Boris Kuzmanovic and Coert van Lare for many fruitful discussions and Rutger Wilts and plant operators for their excellent cooperation during the on-site trial.

\section{References}

[1] M. Kyburz, G.W. Meindersma, in: A.I. Schäfer, A.G. Fane, T.D. Waite (Eds), Nanofiltration - Principles and Applications, Elsevier Ltd, Oxford, UK, 2005, pp. 329-361.

[2] Z. Twardowski, Nanofiltration of concentrated aqueous salt solutions, EP 0821 615 B2.

[3] D. Bessarabov and Z. Twardowski, Membr. Techn., September 2002, 6-9.

[4] A.I. Schäfer, N. Andritsos, A.J. Karabelas, E.M.V. Hoek, R. Schneider and M. Nyström in: A.I. Schäfer, A.G. Fane, T.D. Waite (Eds), Nanofiltration Principles and Applications, Elsevier Ltd, Oxford, UK, 2005, pp. 169-240.

[5] G. Bargeman, R.L. Demmer, B. Kuzmanovic, C.E.J. van Lare, M.J.J Mayer, M.A.I. Schutyser, J.B. Westerink, Method for crystallizing soluble salts of divalent anions from brine, WO 2006/045718 A1.

[6] T.D. Waite in: A.I. Schäfer, A.G. Fane, T.D. Waite (Eds), Nanofiltration Principles and Applications, Elsevier Ltd, Oxford, UK, 2005, pp. 147-168. 
[7] W.M. Samhaber and H. Schwaiger, The application of nanofiltration in the salt industry, $14^{\text {th }}$ International congress of Chem and Proc. Eng. (CHISA 2000), Prague August 2000.

[8] J. Tanninen, M. Mänttäri, M. Nyström, Effect of salt mixture concentration on fractionation with NF membranes, Journal of Membrane Science 283 (2006) 57-64. 


\section{Chapter 5}

\section{The effect of membrane characteristics on nanofiltration membrane performance during processing of practically saturated salt solutions}

This chapter has been published as:

G. Bargeman, J.B. Westerink, C.F.H. Manuhutu and A. ten Kate, The effect of membrane characteristics on nanofiltration membrane performance during processing of practically saturated salt solutions, J. Membr. Sci. 485 (2015) 112-122. 


\begin{abstract}
Information on the effect of membrane characteristics on the performance of nanofiltration membranes during processing of concentrated sodium chloride solutions is scarce. This hampers membrane selection for these applications. In this study nanofiltration membranes, ranging from very tight to very open, have been evaluated for processing of sodium chloride solutions obtained from solution mining. Sulfate retention of these membranes is inversely related to their pore radius obtained from membrane characterization. The chloride retention during nanofiltration of practically saturated salt solutions is a function of the sulfate concentration difference between concentrate and permeate. The observed relation is explained by the small sodium chloride chemical potential difference between concentrate and permeate, indicating low membrane resistance for sodium chloride transport. This is concluded from the sodium chloride concentration product ratios of permeate over concentrate, which were found to be between 0.9 and 1 for all membranes evaluated. This ratio is proportionally related to the membrane pore radius obtained from characterization. Based on the results the sulfate and chloride retention of nanofiltration membranes for processing of saturated sodium chloride solutions can now be obtained from a simple characterization experiment.
\end{abstract}




\section{Introduction}

Nanofiltration is a pressure driven membrane technology with membrane characteristics in between those for reverse osmosis and ultrafiltration [1]. This technology is commonly applied in amongst others the water production industry, in the food industry and the chemical industry [1]. One of the applications for which nanofiltration membranes are suitable is the separation of di-valent from mono-valent anions in an aqueous solution. One of the best known examples is the separation of sulfates from chlorides. Other technologies, e.g. liquid-liquid extraction, are being explored for the separation of sulfates from chlorides as well [2]. Yet, nanofiltration is (still) the preferred option for this application. Usually studies that report about this application deal with solutions containing low sulfate and chloride concentrations studied for modeling purposes. However, industrial applications often deal with the separation of more concentrated solutions, such as sea water (for off-shore applications) [3], depleted brines in the chlor/alkali industry (for more efficient sulfate purging) [3], practically saturated brines that are produced in the salt industry $[4,5]$ (e.g. for production of sodium sulfate crystals or processing of other salt brine streams) and, as recently reported, for treating reverse osmosis concentrates obtained from processing of sea water $[6,7]$.

For these types of applications only limited information is available in open literature and there is a lack of fundamental understanding of the performance of nanofiltration membranes for processing of these concentrated salt solutions. Bargeman et al. [5] have made a first effort to relate the chloride retention obtained during processing of salt plant mother liquor to the difference in sulfate concentration between retentate and permeate for NF-270 and Desal 5DK nanofiltration membranes. Although they have obtained a nice relation between the two, fundamental understanding of this relation has not been given. Furthermore, a broad range of nanofiltration membranes with molecular weight cut-offs (MWCO) ranging from 200 Da to 1000 Da are commercially available. It is unclear whether this relation obtained for NF-270 and Desal 5DK applies to other nanofiltration membranes as well. Because of this lack of information selection of a proper membrane for the required application is not straightforward. The objective of this work is to improve the fundamental understanding of processing of nearly saturated sodium chloride solutions with nanofiltration membranes and to facilitate the selection of these membranes for practical applications. Therefore a range of nanofiltration membranes based on different polymers and with different MWCO (as 
reflected by differences in average pore radii) have been evaluated. The membranes have been characterized with pure water and model solutions containing a single neutral solute to obtain pore radius and effective membrane thickness, and model solutions containing a single salt. The retention characteristics of the membranes obtained during single salt solutions experiments have been related to the obtained pore radii of the membranes. Subsequently, sulfate retentions obtained during nanofiltration of practically saturated salt solutions originating from solution mining have been related to the pore radii from the characterization experiments, and chloride retentions have been related to the difference in sulfate concentrations between retentate and permeate for all evaluated membranes. Obtained results have furthermore been explained by thermodynamic considerations.

\section{Theoretical considerations}

2.1. Determination of the pore radius and effective thickness during membrane characterization

The extended Nernst-Planck description is most often used to interpret the flux and retention results obtained from nanofiltration experiments. Therefore this description was used in the current study as well to obtain membrane pore radii and effective thicknesses from characterization experiments using single solute glycerol, glucose or sucrose solutions. The mean pore radius and effective thickness reported in this study were obtained using the equations described in $[8,9]$ and below.

For uncharged solutes such as glycerol, glucose or sucrose, the transport through the membrane is governed purely by diffusive and convective flows. Consequently, the Nernst-Planck equation yields:

$j_{i}=-D_{i, p} \frac{d c_{i}}{d x}+K_{i, c} c_{i} v$

where

$D_{i, p}=K_{i, d} D_{i, \infty}$

$K_{i, d}$ and $K_{i, c}$, account for the hindrance due to diffusion and convection respectively, and can be related to the hydrodynamic coefficients $K^{1}$ (enhanced drag) and $G$ (lag coefficient) according to the following equations [8]: 


$$
\begin{aligned}
& K^{-1}(\lambda, 0)=1.0-2.3 \lambda+1.154 \lambda^{2}+0.224 \lambda^{3} \\
& G(\lambda, 0)=1.0+0.054 \lambda-0.988 \lambda^{2}+0.441 \lambda^{3}
\end{aligned}
$$

where

$$
\lambda=\frac{r_{s}}{r_{p}}
$$

In equation (5) $r_{s}$ represents the solute radius and $r_{p}$ the mean pore radius of the membrane.

In our approach it is assumed that the solute velocity was fully developed [8] and the solute velocity had a parabolic profile of the Hagen-Poiseuille type. Thus the hindrance factors become [8]:

$$
\begin{aligned}
& K_{i, d}=K^{-1}(\lambda, 0) \\
& K_{i, c}=(2-\Phi) G(\lambda, 0)
\end{aligned}
$$

where

$$
\Phi=(1-\lambda)^{2}
$$

Equation (1) can be expressed in terms of real rejection of the solute by the membrane as:

$$
R_{\text {real }}=\frac{C_{i, m}-C_{i, p}}{C_{i, m}}=1-\frac{K_{i, c} \Phi}{1-\exp \left(-P e_{m}\right)\left[1-\Phi K_{i, c}\right]}
$$

where the Peclet number $\mathrm{Pe}_{m}$ is defined as:

$$
P e_{m}=\frac{K_{i, c} J}{K_{i, d} D_{i, \infty}} \frac{\Delta x}{A_{k}}
$$

where $J$ represents the permeate flux in $\left(\mathrm{m}^{3} \mathrm{~m}^{-2} \mathrm{~s}^{-1}\right), D_{i, \infty}$ is the bulk diffusivity in $\left(\mathrm{m}^{2} \mathrm{~s}^{-1}\right)$ and $\Delta x / A_{k}$ is the effective membrane thickness (m). 
To properly calculate the pore radius of the different membranes from single neutral solute solution experiments concentration polarization at the membrane surface was taken into account as well. The relation between the real retention and the observed retention can be obtained from $[8,9]$ :

$\ln \left(\frac{1-R_{\text {obs }}}{R_{\text {obs }}}\right)=\ln \left(\frac{1-R_{\text {real }}}{R_{\text {real }}}\right)+\frac{J}{k}$

where the observed retention (in the remainder of this work referred to as retention) is defined as:

$$
R_{o b s}=1-\frac{C_{p}}{C_{c}}
$$

Since cross-flow operation was used in this study, the correlation for the mass transfer coefficient $k$ as proposed in [8] for dead end stirred cell operation could not be used. Consequently, we assumed the mass transfer coefficient $k$ to be equal to the ratio of the diffusion coefficient at infinite dilution $D_{\infty}$ over the film thickness $\delta$. On the basis of earlier studies in the DSS labstak at similar flow-rate [10] a constant value for the film thickness of $\delta=2.0 * 10^{-5} \mathrm{~m}$ has been selected.

Furthermore, in the approach described in $[8,9]$, the effective membrane thickness $\Delta x / A_{k}$ was obtained from the Hagen-Poiseuille equation using the pure water flux of the membrane:

$$
\frac{J_{w}}{\Delta P}=\frac{r_{p}{ }^{2}}{8 \eta\left(\Delta x / A_{k}\right)}
$$

where $J_{w} / \Delta P$ is the pure water permeance in $\left(\mathrm{m}^{-\mathrm{s}^{-1}} \cdot \mathrm{kPa} \mathrm{a}^{-1}\right)$ and $\eta$ is the dynamic viscosity of the solution in (kPa.s). 


\subsection{Thermodynamic considerations for sodium chloride salting-out by sodium sulfate}

during nanofiltration operation processing nearly saturated salt solution.

In earlier work [5] the retention of NF-270 and Desal 5DK for chloride during nanofiltration of saturated mother liquor brines (with very high sulfate concentrations in the solution) was shown to be negative and a function of the difference in sulfate concentration between concentrate and permeate. The observed effect is ascribed to the salting-out effect on (sodium) chloride due to the presence of (sodium) sulfate. Salting-out is a well-known phenomenon in extraction and crystallization processes, where the solubility of a specific salt is reduced e.g. by the addition of a common-ion salt (Le Chatelier's principle), leading to crystallization. Similarly, during nanofiltration of salt solutions practically saturated in sodium chloride, the concentration of sodium sulfate in the retentate leads to salting-out of sodium chloride due to common ion effects. This salting-out effect can either lead to sodium chloride crystallization in the retentate, or to sodium chloride passage through the semi-permeable nanofiltration membrane. Since the retention of the nanofiltration membranes at high $\mathrm{NaCl}$ concentrations is close to 0 for single salt solutions, and long term nanofiltration operation for salt solutions saturated in both sodium chloride and sodium sulfate is possible [5], which would not be expected for situations where crystals are produced in the retentate, it is assumed that the primary salting-out effect is the transport through the nanofiltration membrane. Salting-out of the sodium chloride for practically saturated sodium chloride solutions is a thermodynamic phenomenon. In nanofiltration processes per definition the chemical potential of the permeate is lower than the chemical potential of the concentrate due to transport related resistances. This means that the following equation applies for ion $\mathrm{i}$ :

$\mu_{\mathrm{i}}(\mathrm{X}, \mathrm{P}, \mathrm{T})_{\mathrm{c}}-\mu_{\mathrm{i}}(\mathrm{x}, \mathrm{P}, \mathrm{T})_{\mathrm{p}}=\Delta \mu_{\mathrm{i}, \text { membr. }}$

(chemical potential of ion $\mathrm{i}$ in concentrate - chemical potential of ion $\mathrm{i}$ in permeate $=$ resistance membrane for transport of ion i)

In this equation the transport resistance for ion i through the membrane (including resistances due to concentration polarization) is equal to the difference between the chemical potential of ion $\mathrm{i}$ in the retentate (concentrate) and the chemical potential of ion $i$ in the permeate. The chemical potential drop is a measure of the non-equilibrium over the membrane. It is an expression of the driving force over the membrane that 
drives the transport through the membrane. Note that since the equation is a definition of the membrane transport resistance in terms of chemical potential, it is also exact, meaning that it is without any approximations.

The equation resembles other equations, like the Maxwell-Stefan equation, which in fact provides an approximation for the membrane transport resistance as function of process variables such as concentrations and velocities and physical parameters such as the friction coefficient. The Maxwell-Stefan modelling approach specifies the membrane resistance as the friction between the individual solutes and between the solutes and the membrane, as illustrated in equation (15) for a situation when an electrical potential difference would be present [11, 12]:

$\mu_{i}(x, P, T)_{c}+z_{i} F \Psi_{c}-\mu_{i}(x, P, T)_{p}-z_{i} F \Psi_{p}=\Sigma_{j}\left(x_{j} \zeta_{i, j}\left(v_{i}-V_{j}\right)\right) \Delta l$

Since in our nanofiltration experiments an external electrical potential difference over the membrane is not applied and electro-neutrality conditions apply to the concentrate and permeate, the electrical potential difference driving force for the overall process $\left(\Psi_{c}-\Psi_{p}\right)$ as described in equation (15) can be neglected, resulting in equation (16).

$\mu_{\mathrm{i}}(\mathrm{x}, \mathrm{P}, \mathrm{T})_{\mathrm{c}}-\mu_{\mathrm{i}}(\mathrm{x}, \mathrm{P}, \mathrm{T})_{\mathrm{p}}=\Sigma_{\mathrm{j}}\left(\mathrm{x}_{\mathrm{j}} \zeta_{\mathrm{i}, \mathrm{j}}\left(\mathrm{u}_{\mathrm{i}}-\mathrm{u}_{\mathrm{j}}\right)\right) \Delta \mathrm{l}$

The right hand side of equation (16) is an expression for the membrane resistance as defined in equation (14). In fact, it provides an approximation for the observed drop in chemical potential.

Neglecting the difference in chemical potential caused by the transport of $\mathrm{Na}^{+}$and $\mathrm{Cl}^{-}$ through the membrane, thus assuming that the membrane resistance for transport of these ions is relatively small and even negligible, equations (14) and (16) can be simplified to (assuming that the concentrate and retentate are incompressible fluids):

$\mu_{\mathrm{i}}(\mathrm{x}, \mathrm{P}, \mathrm{T})_{\mathrm{c}}-\mu_{\mathrm{i}}(\mathrm{x}, \mathrm{P}, \mathrm{T})_{\mathrm{p}}=\Delta \mu_{\mathrm{i}, \text { membr. } \sim 0} \quad$ for $\mathrm{i}=\mathrm{Na}^{+}$and $\mathrm{Cl}^{-}$

or

$\mu_{i}\left(x, P_{o}, T\right)_{c}+V_{m, i}\left(P_{c}-P_{o}\right)-\mu_{i}\left(x, P_{o}, T\right)_{p}+V_{m, i}\left(P_{p}-P_{o}\right)=\Delta \mu_{i, m e m b r .} \sim 0$

$$
\text { for } \mathrm{i}=\mathrm{Na}^{+} \text {and } \mathrm{Cl}^{-}
$$


This furthermore means that for the sum of the chemical potentials for sodium and chloride the following equation applies:

$\Sigma_{i} \mu_{i}\left(x, P_{o}, T\right)_{c}=\Sigma_{i} \mu_{i}\left(x, P_{o}, T\right)_{p}-\Sigma_{i} V_{m, i}\left(P_{c}-P_{p}\right) \quad$ for $\mathrm{i}=\mathrm{Na}^{+}$and $\mathrm{Cl}^{-}$

Since concentrate and permeate temperatures are similar $\left(T_{c}=T_{p}=T\right)$ and the transmembrane pressure $\Delta P=P_{c}-P_{p}$, this furthermore means that:

$\mu^{*}{ }_{\mathrm{NaCl}}+\mathrm{RT} \ln \left(\mathrm{a}_{\mathrm{Na}}+\right)_{\mathrm{c}}+\mathrm{RT} \ln \left(\mathrm{a}_{\mathrm{Cl}}-\right)_{\mathrm{c}}=\mu^{*}{ }_{\mathrm{NaCl}}+\mathrm{RT} \ln \left(\mathrm{a}_{\mathrm{Na}}+\right)_{\mathrm{p}}+\mathrm{RT} \ln \left(\mathrm{a}_{\mathrm{Cl}}\right)_{\mathrm{p}}-\mathrm{V}_{\mathrm{m}, \mathrm{NaCl}} \Delta \mathrm{P}$

with $\mu^{*} \mathrm{NaCl}=\Sigma_{\mathrm{i}} \mu_{\mathrm{i}}\left(\mathrm{x}_{\mathrm{ref}}, \mathrm{P}_{\mathrm{o}}, \mathrm{T}\right)^{*}$ and $\mathrm{V}_{\mathrm{m}, \mathrm{NaCl}}=\Sigma_{\mathrm{i}} \mathrm{V}_{\mathrm{m}, \mathrm{i}} \quad$ for $\mathrm{i}=\mathrm{Na}^{+}$and $\mathrm{Cl}^{-}$.

This equation can be simplified to:

$\ln \left(\left(\mathrm{a}_{\mathrm{Na}}+. \mathrm{a}_{\mathrm{Cl}}\right)_{\mathrm{c}} /\left(\mathrm{a}_{\mathrm{Na}}+. \mathrm{a}_{\mathrm{Cl}}\right)_{\mathrm{p}}\right)=\mathrm{V}_{\mathrm{m}, \mathrm{NaCl}}(-\Delta \mathrm{P} / \mathrm{R} \mathrm{T})$

The apparent molar volume of an electrolyte (such as $\mathrm{V}_{\mathrm{m}, \mathrm{NaCl}}$ ) is described according to Masson's rule [13] and obtained from the density of the $\mathrm{NaCl}$ solutions. Since the sodium chloride concentration used in our experiments was below $5.6 \mathrm{M}$ and the pressure difference was (mostly substantially) below $35^{*} 10^{5} \mathrm{~Pa}$ in all cases, the value for $V_{m, N a C l}\left(P_{p}-P_{c}\right) /(R T)$ will be between $-3.0^{*} 10^{-2}$ and 0 . Consequently, the exponent of this value will be between 0.97 and 1.0. This means that the effect of the pressure difference between the concentrate and permeate side on the chemical potential is relatively small. Thus, assuming that the contribution of the pressure term can be neglected, equation (21) can be simplified to:

$\ln \left(\mathrm{a}_{\mathrm{Na}}+. \mathrm{a}_{\mathrm{Cl}}\right)_{\mathrm{C}}=\ln \left(\mathrm{a}_{\mathrm{Na}}+. \mathrm{a}_{\mathrm{Cl}}\right)_{\mathrm{p}}$

or

$\left(\gamma_{\mathrm{Na}}+\cdot \mathbf{x}_{\mathrm{Na}}+\cdot \gamma_{\mathrm{Cl}^{-}} \cdot \mathbf{x}_{\mathrm{Cl}^{-}}\right)_{\mathrm{C}}=\left(\gamma_{\mathrm{Na}}+\cdot \mathbf{x}_{\mathrm{Na}}+\cdot \gamma_{\mathrm{Cl}^{-}} \cdot \mathbf{x}_{\mathrm{Cl}^{-}}\right)_{\mathrm{p}}$ 
Modification of equation (23) from ion mole fractions to ion concentrations can be done by replacing the ion mole fraction by the product of the ion molar concentration and the molar volume of the solution, leading to:

$$
\left(\gamma_{\mathrm{Na}^{+}} \cdot\left[\mathrm{Na}^{+}\right] \cdot \mathrm{V}_{\mathrm{m}} \cdot \gamma_{\mathrm{Cl}^{-}} \cdot\left[\mathrm{Cl}^{-}\right] \cdot \mathrm{V}_{\mathrm{m}}\right)_{\mathrm{c}}=\left(\gamma_{\mathrm{Na}^{+}} \cdot\left[\mathrm{Na}^{+}\right] \mathrm{V}_{\mathrm{m}} \cdot \gamma_{\mathrm{Cl}^{-}} \cdot[\mathrm{Cl}] \cdot \mathrm{V}_{\mathrm{m}}\right)_{\mathrm{p}}
$$

Assuming that the activity coefficients in permeate and concentrate are similar and the molar volumes of permeate and concentrate are similar as well, this is furthermore simplified to:

$\left(\left[\mathrm{Na}^{+}\right]_{\mathrm{p}} \cdot\left[\mathrm{Cl}_{\mathrm{p}}^{-}\right]_{\mathrm{p}}\right) /\left(\left[\mathrm{Na}^{+}\right]_{\mathrm{C}} \cdot\left[\mathrm{Cl}^{-}\right]_{\mathrm{C}}\right)=\beta_{\mathrm{NaCl}} \approx 1$

Thus, for sodium chloride salting-out through the nanofiltration membrane by sodium sulfate, a similar chemical potential for sodium chloride in permeate and concentrate should be reflected by a ratio of the sodium chloride concentration product in the permeate over that in the concentrate $\left(\left[\mathrm{Na}^{+}\right]_{\mathrm{p}} \cdot\left[\mathrm{Cl}_{\mathrm{p}}\right]_{\mathrm{p}}\right) /\left(\left[\mathrm{Na}^{+}\right]_{\mathrm{C}} \cdot\left[\mathrm{Cl}^{-}\right]_{\mathrm{c}}\right)$ or $\beta_{\mathrm{NaCl}}$ close to 1 . It should be noted that as a consequence of the presence of sulfate, the sodium concentration and chloride concentration in the concentrate and permeate are not necessarily the same for electro-neutrality reasons.

Equation (25) holds when the activity coefficients for $\mathrm{NaCl}$ in the concentrate and the permeate are similar, the molar volumes of permeate and concentrate are similar and the effect of the pressure difference and the membrane resistance (including resistance effects due to concentration polarization) on the chemical potential is relatively small as stated earlier. A deviation of the concentration product ratio $\beta_{\mathrm{NaCl}}$ from 1 is caused by the small resistance of the membrane for $\mathrm{NaCl}$ transport, and the deviation of the ratio of the molar volumes of permeate and concentrate and of the ratio of activity coefficients from 1 (see equations (14) to (25)). This activity coefficient ratio effect can be caused by the presence of a salting-out component, such as sodium sulfate, in the nearly saturated $\mathrm{NaCl}$ solution. This presence will lead to deviations of the ratio of activity coefficients $\left(\gamma_{\mathrm{Na}^{+}}+\gamma_{\mathrm{Cl}}\right)_{\mathrm{C}} /\left(\gamma_{\mathrm{Na}^{+}}+\gamma_{\mathrm{Cl}}\right)_{\mathrm{p}}$ and the ratio of the molar volumes of the concentrate and permeate solutions $\left(V_{m, c} / V_{m, p}\right)^{2}$ from 1 , especially when the salting-out agent is retained well by the nanofiltration membrane and is present at high concentration. 
The concentration product ratio $\beta_{\mathrm{NaCl}}$ will be used in this manuscript to explain the experimental observations for nanofiltration of saturated salt solutions.

\section{Experimental}

\subsection{Evaluated membranes}

Nanofiltration lab-scale and module-scale experiments have been conducted with NF270 and NF-90 (both Dow / Filmtec), Desal 5DK (GE/Osmonics), NTR-7410, NTR7450, NTR-7470 and NTR-7250 (all Nitto Denko), and TS-80, TS-82, and XN-45 (all TriSep). Characteristics of these membranes as provided by the membrane supplier can be found in Table 1.

Table 1: Membrane characteristics information provided by membrane suppliers for commercially available NF membranes.

\begin{tabular}{|c|c|c|c|c|c|}
\hline $\begin{array}{l}\text { Membrane } \\
\text { type }\end{array}$ & $\begin{array}{l}\mathrm{pH} \\
\text { range }\end{array}$ & $\begin{array}{l}\mathrm{T}_{\max } \\
\left({ }^{\circ} \mathrm{C}\right)\end{array}$ & $\begin{array}{l}P_{\max } \\
\text { (bar) }\end{array}$ & $\begin{array}{l}\text { Permeance } \\
\left(\mathrm{L} \cdot \mathrm{m}^{-2} \cdot \mathrm{h}^{-1} \cdot \mathrm{bar}^{-1}\right)\end{array}$ & $\begin{array}{l}\text { Retention } \\
(\%)\end{array}$ \\
\hline NF-270 & $3-10$ & 45 & 41 & $11^{b}-13^{a}$ & $\begin{array}{l}>97 \text { for } 2 \mathrm{~g} / \mathrm{IgSO}_{4} \text { at } 5 \text { bar } \\
40-60 \text { for } 0.5 \mathrm{~g} / \mathrm{C} \mathrm{CaCl}_{2} \text { at } 5 \text { bar }\end{array}$ \\
\hline NF-90 & $3-10$ & 45 & 41 & $6.4^{\mathrm{b}}$ & $\begin{array}{l}>97 \text { for } 2 \mathrm{~g} / \mathrm{l} \mathrm{MgSO}_{4} \text { at } 5 \mathrm{bar} \\
85-95 \text { for } \mathrm{NaCl}\end{array}$ \\
\hline NTR-7450 & $2-11$ & $90^{\mathrm{c}}$ & 50 & 11 & 50 for $2 \mathrm{~g} / \mathrm{l} \mathrm{NaCl}$ at 10 bar \\
\hline NTR-7410 & $2-11$ & $90^{\mathrm{c}}$ & 50 & 18 & 10 for $2 \mathrm{~g} / \mathrm{l} \mathrm{NaCl}$ at 10 bar \\
\hline NTR-7470 & $2-11$ & 40 & 50 & 4 & 70 for $2 \mathrm{~g} / \mathrm{l} \mathrm{NaCl}$ at 10 bar \\
\hline NTR-7250 & $2-8$ & 40 & 30 & 4 & 50 for $2 \mathrm{~g} / \mathrm{l} \mathrm{NaCl}$ at 10 bar \\
\hline Desal 5DK & $2-11$ & 50 & 35 & 5.5 & 98 for $2 \mathrm{~g} / \mathrm{l} \mathrm{MgSO}{ }_{4}$ at 7 bar \\
\hline TS-80 & $4-11$ & & 41 & 5 & 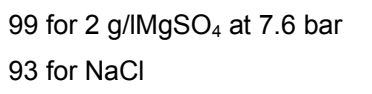 \\
\hline TS-82 & $4-11$ & & & 5.5 & 88 for $\mathrm{NaCl}$ \\
\hline $\mathrm{XN}-45$ & $4-11$ & & 41 & 5 & $\begin{array}{l}95 \text { for } 2 \mathrm{~g} / \mathrm{l} \mathrm{MgSO} \text { at } 7.6 \text { bar } \\
25 \text { for } 0.5 \mathrm{~g} / \mathrm{l} \mathrm{NaCl}\end{array}$ \\
\hline
\end{tabular}

${ }^{a}$ For $\mathrm{CaCl}_{2}$ solutions instead of de-mineralized water

b $\mathrm{For} \mathrm{MgSO}_{4}$ solutions instead of de-mineralized water

c Special high temperature versions, normal versions with maximum temperatures of $40^{\circ} \mathrm{C}$. For the other membranes special high temperature versions may be available as well. 
NTR-7410 and NTR-7450 are reported to be sulfonated poly(ether)sulfone (SPES) membranes [14-16]. NTR-7470 is reported to be a polysulfone based membrane as well [17] and is most likely made out of the same materials as the other two membranes from the NTR-74xx series, whereas NTR-7250 is a polypiperazine amide based membrane [15]. TS-80, XN-45, NF-90, NF-270 and Desal 5DK are polyamide (PA) based membranes as well $[18,19]$. For TS- 82 information about the membrane material is not available in open literature to the best of our knowledge. However, this membrane most likely consists of polyamide as well, similar to the other two TriSep membranes evaluated in this work.

\subsection{Experimental set-up}

Most (lab scale) experiments were carried out using a DSS Labstak® M20 equipment as described by Van der Horst et al. [20]. The experiments were performed in batch circulation mode, meaning that both the retentate (concentrate) and permeates were recycled continuously to the liquid vessel. Each membrane type installed in the labstack equipment had a surface area of $0.036 \mathrm{~m}^{2}$. In the DSS Labstak® M20 equipment used, the liquid was supplied to the top of the membrane stack, flowing downwards to the outlet at the bottom of the stack. Pressure indicators were placed at the liquid inlet and the outlet (retentate side) of the Labstak $®$ M20. Temperature was controlled in the liquid vessel of the equipment. A Hydracel pump was used to pump the liquid from the liquid vessel to the Labstak ${ }^{\circledR}$ M20. A Julabo cooling unit was used to control the temperature of the liquid to the membrane equipment. The cooling liquid was sent to a cooler installed in the liquid vessel.

A few experiments using 4 inch NF-270 membrane modules were performed. Membrane surface area per module was $7.6 \mathrm{~m}^{2}$. The equipment used consisted of a high pressure liquid pump, two recirculation pumps recycling the majority of the concentrate produced back to the inlet of the individual modules and a concentrate outlet and two permeate outlets. Continuous experiments were performed under steady state conditions with two NF-270 modules in series, each having their own recirculation loop. Flows, pressures and temperatures were monitored continuously.

\subsection{Solutions used during characterization and nanofiltration of saturated salt solutions}

During lab-scale characterization experiments de-mineralized water and liquid solutions containing $1 \mathrm{~g}^{\mathrm{L}} \mathrm{L}^{-1}$ of a single solute were used. These solutions were created by 
dissolving analytical grade sucrose, glucose, glycerol (all obtained from Fischer Emergo, The Netherlands), or $\mathrm{NaCl}, \mathrm{Na}_{2} \mathrm{SO}_{4}$ (anhydrous), $\mathrm{MgSO}_{4}$, or $\mathrm{CaCl}_{2}$ (all obtained from Sigma Aldrich) in de-mineralized water. Relevant properties of these solutes are listed in Table 2.

Table 2: Diffusivities and Stokes radii used for ions and neutral solutes [10, 11, 21].

\begin{tabular}{lccc}
\hline Solute & $\begin{array}{c}\text { Ionic or molecular weight } \\
\left(\mathrm{g} \mathrm{mol}^{-1}\right)\end{array}$ & $\begin{array}{c}\text { Diffusivity } \\
\mathrm{D}\left(\mathrm{m}^{2} \mathrm{~s}^{-1}\right) \times 10^{-9}\end{array}$ & $\begin{array}{c}\text { Solute radius } \\
\mathrm{r}_{\mathrm{s}}(\mathrm{nm})\end{array}$ \\
\hline $\mathrm{Na}^{+}$ & 23 & 1.33 & 0.161 \\
$\mathrm{Mg}^{2+}$ & 24.3 & 0.706 & 0.305 \\
$\mathrm{Cl}^{-}$ & 35.5 & 2.03 & 0.106 \\
$\mathrm{SO}_{4}{ }^{2-}$ & 96 & 1.07 & 0.202 \\
$\mathrm{Glycerol}^{-}$ & 92 & 0.81 & 0.264 \\
Glucose & 180 & 0.60 & 0.360 \\
Sucrose & 342 & 0.46 & 0.470 \\
\hline
\end{tabular}

During the saturated salt solution experiments practically saturated raw brines from different origins (Delfzijl, The Netherlands and Mariager, Denmark) were used. Brines were obtained from solution mining by infiltrating water into subterraneous sodium chloride rock salt caverns. The Mariager raw salt solution thus produced was used in the nanofiltration lab-scale experiments as obtained. For Delfzijl raw salt solution used in the module experiments Drewsperse 747A was added in such an amount that the raw salt solution contained a $100 \mathrm{ppm}$ polymaleic acid. The raw salt solutions mainly contained sodium chloride $\left(4.7-5.2 \mathrm{~mol}^{\mathrm{L}} \mathrm{L}^{-1}\right)$ and sodium sulfate $\left(10-15 \mathrm{mmol} . \mathrm{L}^{-1}\right.$ and 45-50 mmol. $\mathrm{L}^{-1}$ for Mariager and Delfzijl, respectively). Only negligible amounts of potassium, calcium, magnesium and bromides were present in the raw salt solutions.

\subsection{Experimental conditions}

Prior to the lab-scale experiments with Mariager raw salt solution the newly installed membrane sheets were flushed with de-mineralized water at 15 bar and $20^{\circ} \mathrm{C}$ during 1 hour, followed by flushing at 25 bar during 10 minutes (permeate was discharged during the entire period). Subsequently, membrane characterization was done in batch mode 


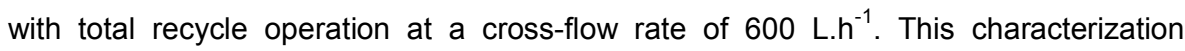
procedure consisted of the following steps:

- $\quad$ Determination of the pure water flux at temperatures between $19^{\circ} \mathrm{C}$ and $20^{\circ} \mathrm{C}$ and three different trans-membrane pressures (7, 15 and 23 bar) using demineralized water.

- Determination of the $\mathrm{NaCl}$ retention at 10 bar trans-membrane pressure and $20.5^{\circ} \mathrm{C}$, using a solution containing $1 \mathrm{~g} \cdot \mathrm{L}^{-1} \mathrm{NaCl}$.

- Determination of the glucose, $\mathrm{MgSO}_{4}$, glycerol, $\mathrm{CaCl}_{2}, \mathrm{Na}_{2} \mathrm{SO}_{4}$ and sucrose retention with single component solutions of $1 \mathrm{~g} \cdot \mathrm{L}^{-1}$ at 10 bar and temperatures of $21^{\circ} \mathrm{C}$

Evaluation of NF membranes for processing raw Mariager salt solution was done at two different trans-membrane pressures (10.5 bar and 21 bar) and temperatures in the range of $20-22^{\circ} \mathrm{C}$. As for the membrane characterization tests the equipment was operated in full recycle mode at a cross-flow rate of $600 \mathrm{~L} . \mathrm{h}^{-1}$ at the inlet of the module. The reduction of the cross-flow rate at the top of the module due to permeate production was less than $3 \%$. Samples of the individual permeates and the concentrate were taken for operation at 21 bar pressure. These samples were analyzed for chloride and sulfate. Since the cross-flow rate was far in excess of the total permeate flow, it is assumed that solution provided to the membrane inlet and the concentrate have the same composition.

Module experiments were performed with Delfzijl raw salt solution. Two NF270 modules in series were used at a temperature of $8^{\circ} \mathrm{C}$ and $13^{\circ} \mathrm{C}$ for the first and second module, respectively. The pressure of the membrane modules was 35 bar and an overall concentration factor (defined as the volume flow of fresh solution over concentrate discharged) of 1.4 was maintained. The cross-flow rate for both modules was $3.1 \mathrm{~m}^{3} / \mathrm{h}$.

Chloride and sulfate concentrations were determined through titration with silver nitrate and ion chromatography, respectively. Sucrose, glucose and glycerol retentions were determined from NPOC (non-purgeable organic carbon) concentrations of concentrates and permeates. $\mathrm{NaCl}, \mathrm{MgSO}_{4}, \mathrm{Na}_{2} \mathrm{SO}_{4}$ and $\mathrm{CaCl}_{2}$ retention during characterization experiments using $1 \mathrm{~g} \cdot \mathrm{L}^{-1}$ single salt solutions were determined from conductivity 
measurements of permeates and the concentrate samples using a WTW LF340 conductivity meter.

\section{Results and discussion}

\subsection{Membrane characterization}

Membrane pure water permeances are shown in Table 3. For NF-270, NTR-7450 and Desal 5DK permeances are within the permeance ranges reported for these membranes [22]. For TS-80 the obtained pure water permeance is close to values reported by the membrane supplier and [18].

Table 3: $\quad$ Pure water permeances for evaluated membranes.

\begin{tabular}{lccc}
\hline Membrane & $\begin{array}{c}\text { Obtained } \\
\text { permeance } \\
\left(\mathrm{L} \cdot \mathrm{m}^{-2} \cdot \mathrm{h}^{-1} \cdot \mathrm{bar}^{-1}\right)\end{array}$ & $\begin{array}{c}\text { Permeance range } \\
\text { from open literature } \\
\left(\mathrm{L} \cdot \mathrm{m}^{-2} \cdot \mathrm{h}^{-1} \cdot \mathrm{bar}^{-1}\right)\end{array}$ & Source \\
\hline NF-270 & 11.5 & $8.6-16$ & summarized in [22] \\
NF-90 & 9.6 & 6.0 & [23] \\
NTR-7450 & 7.4 & $5.8-23$ & summarized in [22] \\
NTR-7410 & 27.6 & & \\
NTR-7470 & 4.3 & & summarized in [22] \\
NTR-7250 & 3.6 & $3.1-7.9$ & \\
Desal 5DK & 4.2 & 5.2 & \\
TS-80 & 6.0 & & \\
TS-82 & 4.7 & & \\
XN-45 & 6.7 & & \\
\hline
\end{tabular}

On the basis of flux and retention results for processing of the single neutral solute solutions, pore radii and effective thicknesses were estimated using the equations (1) (13) as presented earlier. Results are shown in Table 4. For several membranes (NF270, NF-90, NTR-7250, Desal 5DK, TS-80 and TS-82) average pore radii below 0.47 $\mathrm{nm}$ were found. Therefore, pore radii on the basis of processing of the $1 \mathrm{~g} \cdot \mathrm{L}^{-1}$ sucrose solution were not fitted. For these membranes sucrose retentions quite close to $100 \%$ were obtained. Since retentions were slightly below $100 \%$ pore radii could be obtained, but these were obviously in excess of $0.47 \mathrm{~nm}$, which is not representative for these 
membranes. The fact that the sucrose retention was below $100 \%$ is caused by the presence of a pore size distribution. It should be noted that the pore radius fitted is a mean pore radius. For processing of the sucrose solution only the bigger pores of the membrane will contribute to the passage of sucrose, thus leading to a higher mean pore radius as compared to processing of glucose or glycerol solutions. Apart from this phenomenon, practically all membranes showed a pore radius and effective thickness independent of the solute used (see Table 4). In most cases deviations were within $5 \%$. For NTR-7410 a pore radius and effective thickness were not determined from permeation results processing the glycerol solution, since the retention was practically 0 in this case. On the basis of the results the tightness of the individual membranes (going from the most open to the tightest membrane) is:

NTR-7410 >> NTR-7450 >> NTR-7470 >> XN-45 > NTR-7250 > Desal 5DK > NF$270>$ NF-90 $=$ TS- $80=$ TS -82

Table 4: Estimated effective pore radius and effective thickness for evaluated nanofiltration membranes based on processing of $1 \mathrm{~g} \cdot \mathrm{L}^{-1}$ solutions of glycerol, glucose or sucrose.

\begin{tabular}{lcccccc}
\hline Solution & \multicolumn{2}{c}{$1 \mathrm{~g} \cdot \mathrm{L}^{-1}$ glycerol } & \multicolumn{2}{c}{$1 \mathrm{~g} \cdot \mathrm{L}^{-1}$} & glucose & \multicolumn{2}{c}{$1{\mathrm{~g} \cdot \mathrm{L}^{-1}}^{2}$} & sucrose \\
\hline Membrane & $\begin{array}{c}\mathrm{r}_{\mathrm{p}} \\
(\mathrm{nm})\end{array}$ & $\begin{array}{c}\Delta \mathrm{X} / \mathrm{A}_{\mathrm{k}} \\
(\mu \mathrm{m})\end{array}$ & $\begin{array}{c}\mathrm{r}_{\mathrm{p}} \\
(\mathrm{nm})\end{array}$ & $\begin{array}{c}\Delta \mathrm{x} / \mathrm{A}_{\mathrm{k}} \\
(\mu \mathrm{m})\end{array}$ & $\begin{array}{c}\mathrm{r}_{\mathrm{p}} \\
(\mathrm{nm})\end{array}$ & $\begin{array}{c}\Delta \mathrm{x} / \mathrm{A}_{\mathrm{k}} \\
(\mu \mathrm{m})\end{array}$ \\
& & & & & & \\
NF-270 & 0.40 & 0.74 & 0.40 & 0.75 & & \\
NF-90 & 0.35 & 0.77 & 0.38 & 0.89 & & \\
NTR-7450 & 0.83 & 5.5 & 0.84 & 3.9 & 0.83 & 4.3 \\
NTR-7410 & & & 1.4 & 3.3 & 1.2 & 2.8 \\
NTR-7470 & 0.63 & 5.5 & 0.66 & 4.1 & 0.66 & 4.7 \\
NTR-7250 & 0.41 & 1.9 & 0.44 & 2.2 & & \\
Desal 5DK & 0.41 & 1.7 & 0.42 & 1.6 & & \\
TS-80 & 0.36 & 1.2 & 0.38 & 1.3 & & \\
TS-82 & 0.36 & 1.4 & 0.38 & 1.6 & & \\
XN-45 & 0.53 & 1.7 & 0.55 & 1.8 & 0.55 & 1.8 \\
\hline
\end{tabular}


Sodium sulfate and magnesium sulfate retentions obtained during the characterization experiments reduce from $99.5 \%$ to $75 \%$ and $99 \%$ to $6.5 \%$, respectively when the average pore radius increases from $0.35 \mathrm{~nm}$ to $1.2 \mathrm{~nm}$ (see Figs. 1a and 1b).
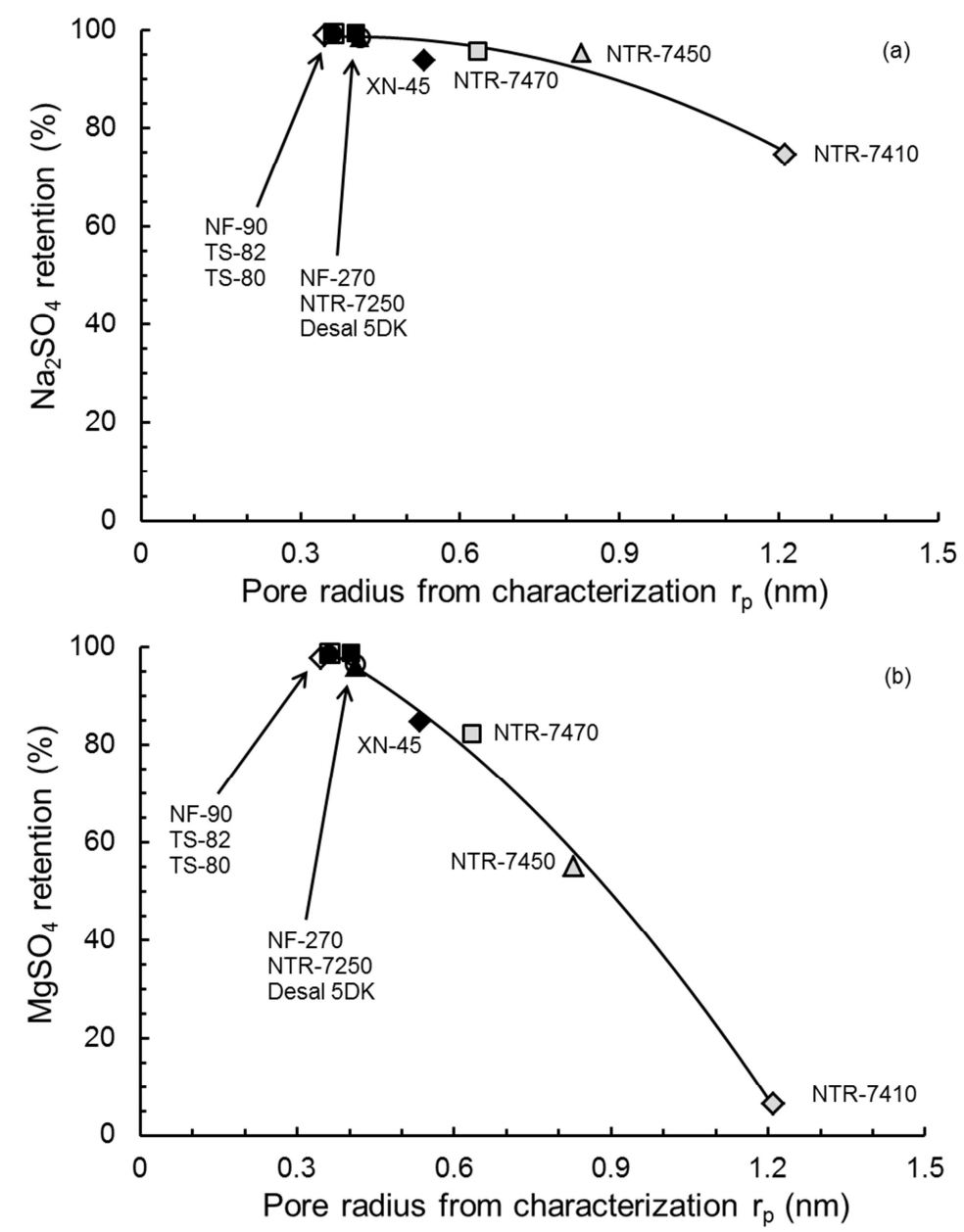

Figure 1: $\quad$ Sodium sulfate (a) and magnesium sulfate (b) retentions for all evaluated membranes as function of pore radius determined via glycerol retention measurements (apart from NTR-7410 for which the pore radius determined from sucrose retention measurements was used). Symbols represent measured results and lines represent the trends for all (PA and SPES) membranes. 
Magnesium sulfate retentions obtained for NF-270, NF-90, TS-80 are in line with values reported by the membrane supplier. For Desal $5 \mathrm{DK}$ and $\mathrm{XN}-45$ slightly lower magnesium sulfate retentions are found than reported by the membrane suppliers. Figure $1 \mathrm{~b}$ seems to indicate that the membrane material used, and therefore the original membrane surface charge density, does not seem to have a significant influence on the retentions for this sulfate salt. This would mean that the separation is either mainly caused by the size exclusion effect or that the surface charge densities for the different membranes have become similar due to adsorption of the ions, and the volumetric charge density, which is inversely related to the pore radius $[11,25]$ determines the retention characteristics. However, it should be realized that although all results can be described by a single relation between magnesium sulfate retention and pore radius based on glycerol characterization experiments, there is no overlap between retention results for the sulfonated polyether sulfone based membranes and those of the polyamine based membranes. Thus additional studies are required to fully elucidate the observed effect.

The magnesium sulfate retention is lower than the sodium sulfate retention for most membranes. This is only partly caused by the slightly lower ionic strength of the $1 \mathrm{~g} \cdot \mathrm{L}^{-1}$ $\mathrm{Na}_{2} \mathrm{SO}_{4}$ solution as compared to the $1 \mathrm{~g} \cdot \mathrm{L}^{-1} \mathrm{MgSO}_{4}$ solution. More importantly, for these low ionic strength solutions negatively charged membranes are reported to have lower retention for di-valent cations than for mono-valent cations when these have the same anion as counter ion [19]. Since characterization experiments have occurred at neutral $\mathrm{pH}$ and the membranes contain sulfonic and carboxylic groups, all membranes are negatively charged at characterization conditions. In this case the volumetric charge densities of the nanofiltration membranes appear to be smaller for the $1 \mathrm{~g}^{-\mathrm{L}^{-1}} \mathrm{MgSO}_{4}$ solution than for the $1 \mathrm{~g} \cdot \mathrm{L}^{-1} \mathrm{Na}_{2} \mathrm{SO}_{4}$ solution. However, other explanations for the observed behavior such as stronger membrane swelling for processing of the $1 \mathrm{~g} \cdot \mathrm{L}^{-1}$ $\mathrm{Na}_{2} \mathrm{SO}_{4}$ solution than for the $1 \mathrm{~g} \cdot \mathrm{L}^{-1} \mathrm{MgSO}_{4}$ solution can be a reason for the observed results as well. This latter hypothetical solution can be verified by performing spectroscopic ellipsometry experiments, but these are outside of the scope of the current study. It should be noted that for sodium sulfate retention, as for magnesium sulfate retention, the membrane material does not seem to influence the sodium sulfate retention, and the retention can be described by a unique relation with the pore radius as obtained from glycerol characterization experiments. However, as for the $1 \mathrm{~g} \cdot \mathrm{L}^{-1}$ 
$\mathrm{MgSO}_{4}$ solution, there is no overlap between the retention results for the sulfonated polyether sulfone based membranes and the polyamine based membranes.

Calcium chloride and sodium chloride retentions decrease with increasing pore size as well (see Fig. 2a and 2b). However, in this case the choice of membrane material also affects the retention for both salts. It is well known that for the retention of sodium chloride membrane charge density plays an important role (Donnan exclusion). Since the sulfonate groups will be more highly charged than the carboxylic groups at neutral $\mathrm{pH}$, it is expected that the charge density of the SPES membranes (NTR-7410, NTR7450 and NTR-7470) will be higher at neutral $\mathrm{pH}$ than that of the PA membranes, provided that the concentration of electrically charged groups on the membrane surface for the SPES membrane is similar or higher than for PA membranes. For example for the SPES based NTR-7450, Nystrom et al. [24] have shown that the charge density is higher than for the PA based membrane NTR-7250. This may explain why SPES membranes can have similar $\mathrm{NaCl}$ retention as the PA membranes at bigger average pore radius (as for example seen for NTR-7450, NF-7470 and NTR-7250 in Figs. 2a and $2 b$ ). The effect of the pore size on the retention for membranes from the same material (or at least quite similar polymeric material) is explained as follows. The membranes produced from the same polymeric material are all expected to have approximately similar surface charge density, because the same charged groups are present. However, for the membranes with bigger pore radii, the membrane charge concentration based on the pore volume, which determines Donnan exclusion, will become smaller since this concentration is proportional to the surface charge density and inversely proportional to the pore radius $[11,25]$. Thus, the Donnan exclusion experienced by the negatively charged (chloride) ions that are retained is on average lower for membranes with similar surface charge density and bigger pores. Consequently, lower chloride retention is found, in line with the observations presented in Figs. $2 a$ and $2 b$. For the PA based membranes it is evident that the materials used and the membrane production processes are not exactly the same for all PA membranes $[26,27]$. These differences may give rise to some deviation from the established relation between pore radius and $\mathrm{NaCl}$ and $\mathrm{CaCl}_{2}$ retention. This can for instance be seen from the reversed sequence of $\mathrm{NaCl}$ and $\mathrm{CaCl}_{2}$ retentions for NTR7250, NF-270 and Desal 5DK membranes. The NaCl retention for NTR-7250 is higher than that for NF-270, which shows higher $\mathrm{NaCl}$ retention than Desal 5DK, whereas the $\mathrm{CaCl}_{2}$ retentions for these membranes show the reversed sequence. Further analysis of 
these differences will be required to fully explain the obtained results in detail, but is outside of the scope of the current study. Nevertheless, as can be seen from Figs. 2a and $2 \mathrm{~b}$, a first indication of the retentions can be obtained from the pore size of the individual membranes.

For NTR-7410, NTR-7450, NTR-7470 and NTR-7250 obtained sodium chloride retentions are slightly higher than reported by the membrane supplier. This is most likely due to the difference in sodium chloride concentration used $\left(1 \mathrm{~g}^{-\mathrm{L}^{-1}}\right.$ in this study vs. $2 \mathrm{~g} \cdot \mathrm{L}^{-1}$ as used in the reported membrane supplier tests) as it is generally known that for negatively charged membranes sodium chloride solutions with higher ionic strength (higher concentrations) show lower sodium chloride retention, as a consequence of screening of the original membrane charge, leading to decreasing electrostatic repulsion of chloride at increasing ionic strength (e.g. [11]). 

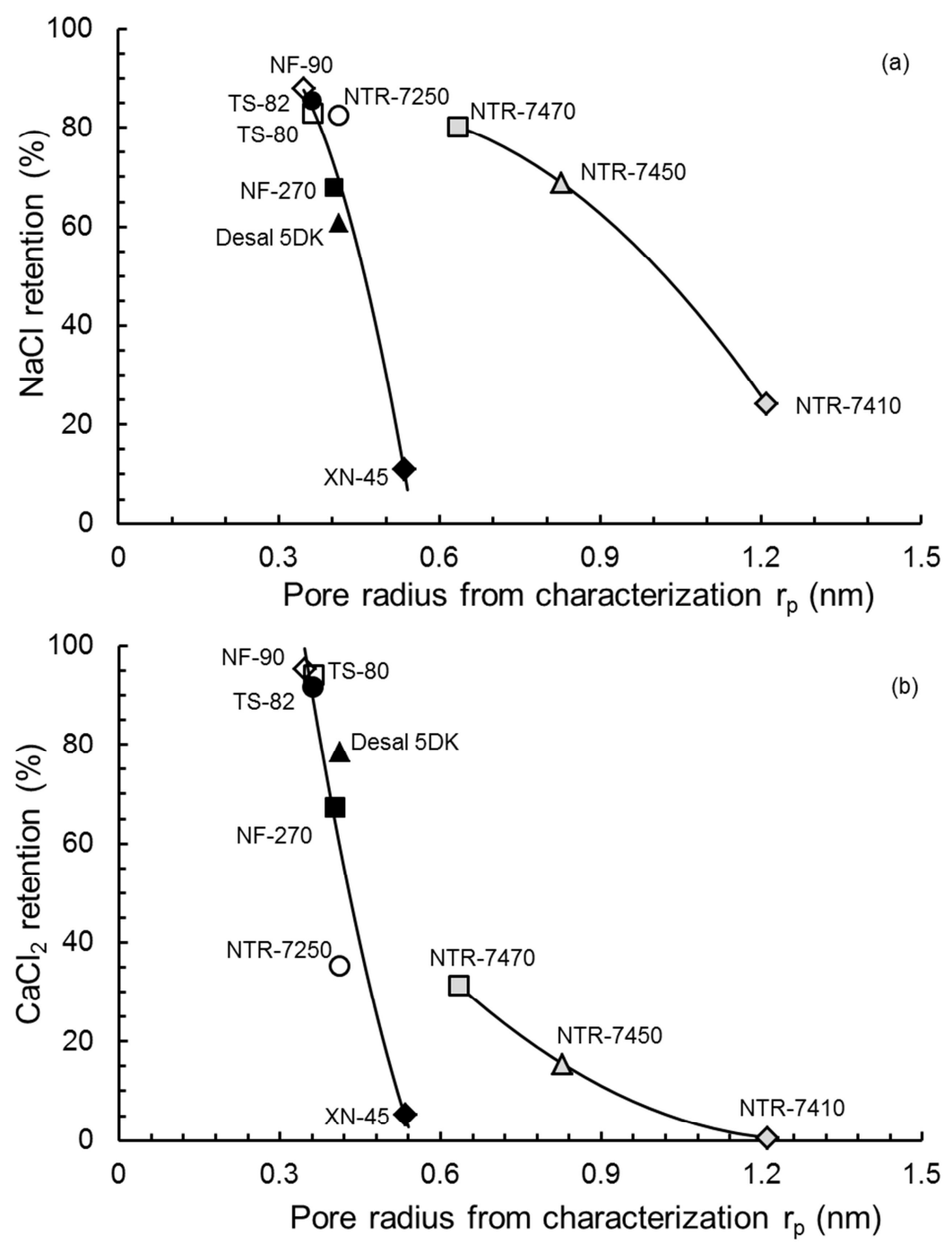

Figure 2: $\quad$ Sodium chloride (a) and calcium chloride (b) retentions for all evaluated membranes as function of pore radius determined via glycerol retention measurements (apart from NTR-7410 for which the pore radius determined from sucrose retention measurements was used). Symbols represent measured results and lines represent the trends for either PA or SPES membranes. 


\subsection{Nanofiltration of practically saturated salt solutions}

For all membranes evaluated the osmotic pressure differences between retentate and permeate, as obtained during processing of Mariager raw salt solution, appear to be limited. For the most open membranes (NTR-7410, NTR-7450, NTR-7470 and XN-45) obtained osmotic pressure differences are between 0 - 1 bar, whereas for tighter membranes (NTR-7250, Desal 5DK and NF270) osmotic pressure differences are between 1 - 2 bar (results not shown). For the tightest membranes (TS-80, TS-82 and NF-90) the flux has become that low, that a proper determination of the osmotic pressure differences was not possible. It should be noted that the osmotic pressure was determined from limited pressure variation results and consequently only gives a first indication. The permeances of the NF membranes obtained during practically saturated salt solution experiments are clearly lower than those obtained during the characterization procedure. On the basis of the ratio of the pure water viscosity over the viscosity of the nearly saturated (and sulfate lean) permeate salt solutions

$\left(\eta_{w} / \eta_{\text {brine permeate }}\right)$ of 0.55 [28], it is expected that the ratio of the salt solution permeance over pure water permeance $\left(\right.$ Perm brine / Perm ${ }_{w}$ ) would be around 0.55 as well for all nanofiltration membranes evaluated. However, this is only true for the most open NF membranes (NTR-7410 and NTR-7450). For tighter NF membranes the ratio of the salt solution permeance over pure water permeance becomes smaller (see Fig. 3). The decrease in this ratio is especially strong for membranes with pore sizes of approximately $0.4 \mathrm{~nm}$. An explanation for this decrease in permeance ratio from the ratio expected on the basis of the bulk viscosities of pure water and salt solution can be the increase in viscosity in narrow NF pores as explained by Bowen and Welfoot [29]. These authors state that this increase in viscosity (and therefore decrease in permeance) for smaller membrane pores is difficult to quantify. Nevertheless, if the change in viscosity for processing of water is different from the change in viscosity for processing of salt solution a permeance ratio different from 0.55 can occur. Another explanation could be that, as a consequence of the presence of a pore size distribution, permeate through tight nanofiltration membranes only flows through the bigger pores at higher permeate viscosity. Since this would lead to a smaller effective porosity of the membrane, permeance would drop more than expected on the basis of bulk viscosity increase when changing from pure water to practically saturated salt solution. Indications for this phenomenon have been reported earlier [10]. 
The sodium sulfate retentions that are obtained during processing of the practically saturated salt solutions are a function of the obtained average pore radius as well (see Fig. 4). Only membranes that showed a membrane flux below $2 \mathrm{~kg} \cdot \mathrm{m}^{-2} \cdot \mathrm{h}^{-1}$ (NF-90, TS82 and TS-80) had relatively low sodium sulfate retentions and deviated from the observed trend. Nanofiltration membranes that are operated at very low flux (typically below $10 \mathrm{~kg} \cdot \mathrm{m}^{-2} \cdot \mathrm{h}^{-1}$ ) commonly show lower retentions than when they are operated at higher membrane flux.

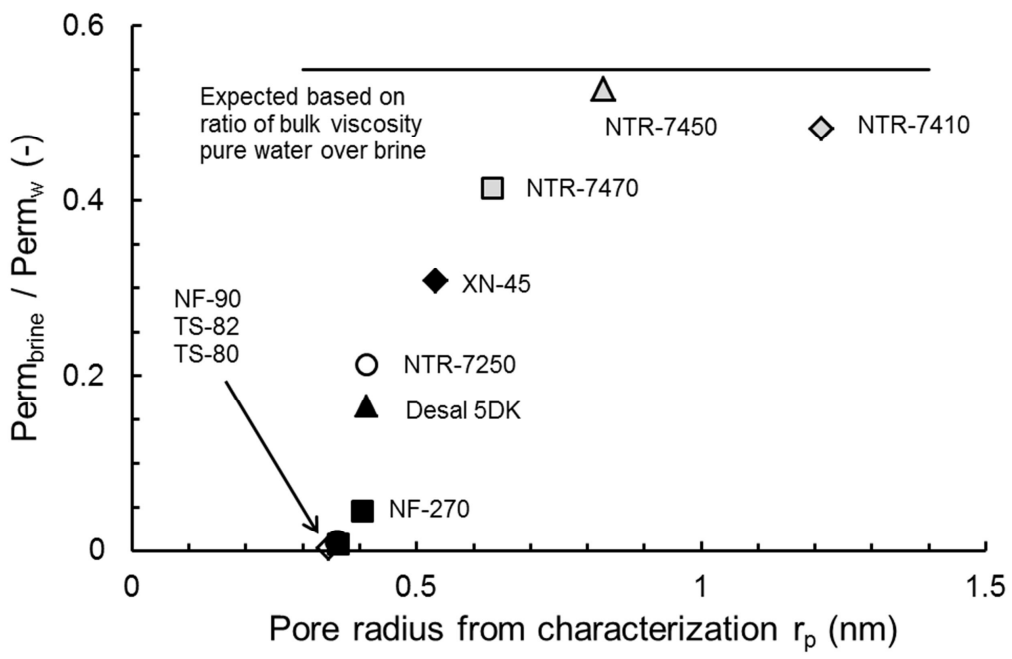

Figure 3: The ratio of salt solution permeance over pure water permeance as function of the pore radius as determined during membrane characterization.

Furthermore, the sodium sulfate retentions during processing of practically saturated salt solutions for all membranes evaluated (see Fig. 4) are lower than those for processing of a $1 \mathrm{~g} . \mathrm{L}^{-1}$ sodium sulfate model solution (see Fig. 1), even though the sodium sulfate concentrations in the salt solution and the model solution are similar. It is generally believed that the ratio of the solute radius over the average pore radius decreases when the ionic strength of a solution increases. Explanations for the changes in solute radius over pore radius ratio at higher salt concentrations can be found in [10, 19, 22 and 30]. Since for the nearly saturated salt solution very high concentrations of sodium chloride are present in the solution it is clear that the ionic strength of the nearly saturated salt solution is significantly higher than that of the $1 \mathrm{~g} \cdot \mathrm{L}^{-1}$ sodium sulfate 
solution used for characterization. Therefore it can be expected that the ratio of the sulfate radius over the pore radius of the nanofiltration membranes will be smaller for the nearly saturated salt solution as compared to the sodium sulfate model solution. Furthermore, the higher ionic strength of the nearly saturated salt solution (as compared to the $1 \mathrm{~g} \cdot \mathrm{L}^{-1}$ sodium sulfate solution used for characterization) leads to shielding of charges (adsorbed) on the membrane surface and in the membrane pores, and consequently may lead to a smaller contribution of Donnan exclusion for the nearly saturated salt solution. These effects can explain why the sulfate retention for processing of the salt solution is lower than that for the sodium sulfate model solution.

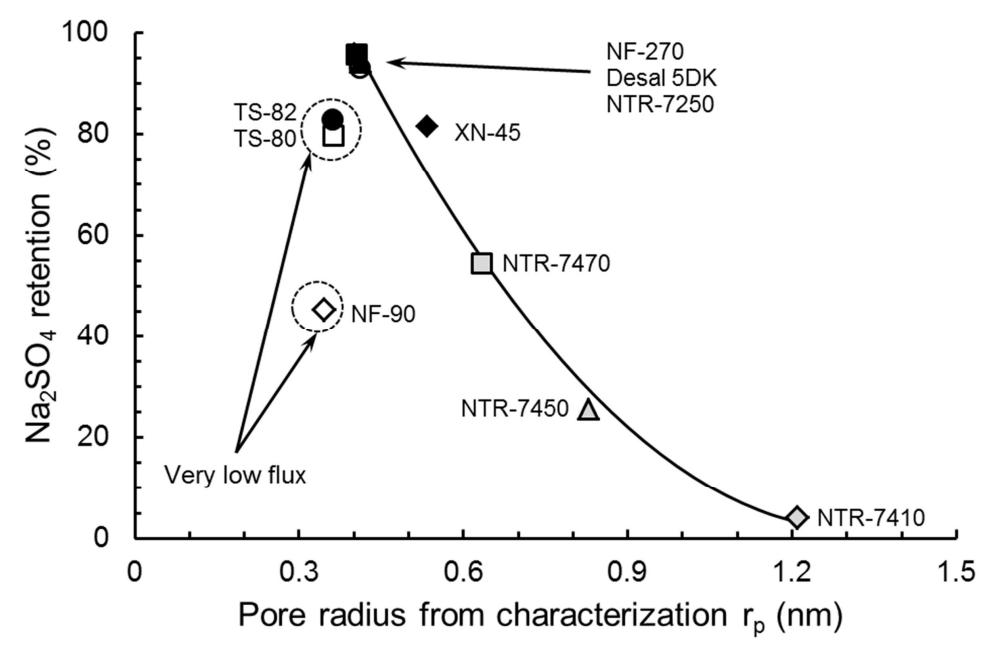

Figure 4: $\quad$ Sodium sulfate retentions for all evaluated membranes during processing of Mariager raw salt solution as function of pore radius determined via glycerol retention measurements (apart from NTR-7410 for which the pore radius determined from sucrose retention measurements was used). Symbols represent measured results and the line represents the trends for PA and SPES membranes having membrane fluxes in excess of 10 $\mathrm{kg} \cdot \mathrm{m}^{-2} \cdot \mathrm{h}^{-1}$.

In earlier work [5] nanofiltration of mother liquor brines from $\mathrm{NaCl}$ salt production with much higher sulfate concentrations of around 550-600 mmol. $\mathrm{L}^{-1}$ and sodium chloride concentrations similar to those used in the current study $\left(4.7-4.9\right.$ mol. $\left.\mathrm{L}^{-1}\right)$ has been described. For the membranes evaluated in that study (NF-270 and Desal 5DK) the 
sodium chloride retention could be described as function of the sulfate concentration difference between retentate and permeate, and negative chloride retentions were obtained. For nanofiltration of raw salt solutions with much lower sulfate concentrations, positive chloride retentions are obtained. These retentions differ only marginally from the extrapolated relation determined for nanofiltration of the mother liquor brine, not only for NF-270 and Desal 5DK (see Fig. 5), but for all other nanofiltration membranes evaluated as well (see Fig. 6). It should be noted that the deviation from the expected retention on the basis of the earlier obtained relation is limited to less than $3 \%$ (absolute). The relation can therefore be used to obtain a first prediction of the chloride retention when the sulfate retention is known or is estimated from the pore radius of the membrane as determined from the characterization experiments. However, for the membranes with a very low sulfate retention and consequently a very small sulfate concentration difference between retentate and permeate, chloride retentions start to marginally deviate from the earlier obtained relation approach zero retention (see Fig.6).

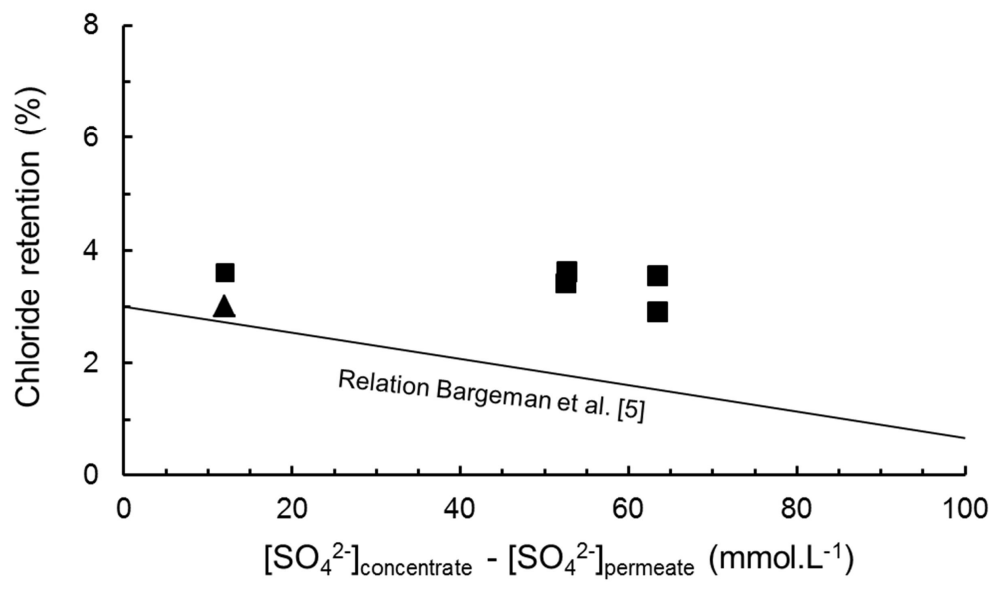

Figure 5: Chloride retentions for NF-270 (squares) and Desal 5DK (triangle) during processing of practically saturated raw salt solutions from Mariager and Delfzijl as function of the difference in sulfate concentration between concentrate and permeate. The line represents a relation found [5] for NF270 and Desal 5DK processing high sulfate containing mother liquor brines. 


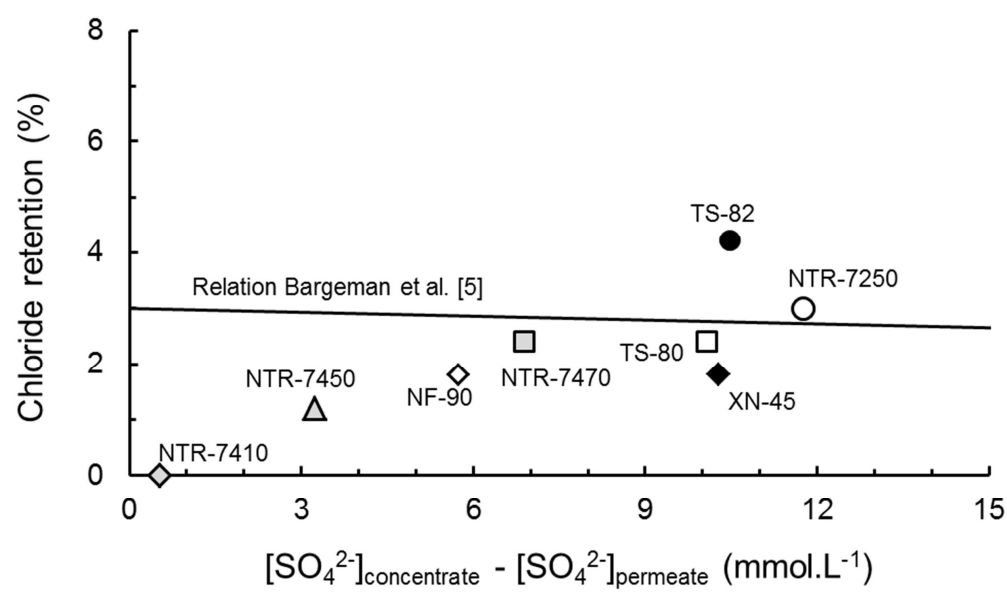

Figure 6: Chloride retentions for all evaluated membranes during processing of practically saturated salt solution as function of the difference in sulfate concentration between concentrate and permeate. The line represents a relation found [5] for NF-270 and Desal 5DK processing high sulfate containing mother liquor brines.

A more accurate prediction of the sodium chloride retention for these membranes and an explanation why the deviation from observed chloride retentions from the extrapolated relation occurs is therefore desired. Furthermore, to the best of our knowledge an explanation for the observation that the sodium chloride retentions for all nanofiltration membranes, ranging from very tight to very open, can be predicted reasonably well by the obtained relation between chloride retention and the difference in sulfate concentration between retentate and permeate has not been given in open literature so far. 


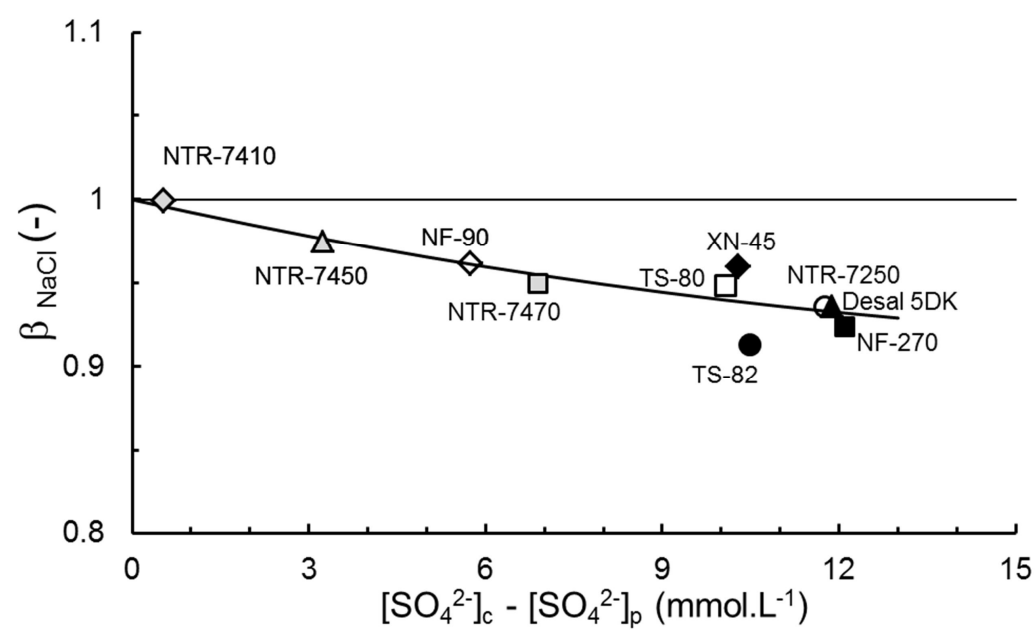

Figure 7: $\quad$ Sodium chloride concentration ratio $\beta$ NaCl for all evaluated membranes during processing of practically saturated Mariager raw salt solution as function of the difference in sulfate concentration between concentrate and permeate.

Translation of the retention results for the raw salt solution experiments into the concentration product ratio for sodium chloride in the permeate over the retentate $\left(\beta_{\mathrm{NaCl}}\right)$ reveals that at small differences in sulfate concentration between concentrate and permeate, values slightly lower but very close to 1 are found for all membranes evaluated (see Figs. 7 and 8). Based on the theoretical considerations explained earlier in this document this means that the resistance for sodium chloride transport is very small, molar volumes of concentrates and permeates are similar, and activity coefficients in retentate and permeate are similar for processing of the raw salt solutions containing low amounts of sulfate, irrespective of which nanofiltration membrane is used. It furthermore means that the chemical potential of sodium chloride in both phases (permeate and retentate) is practically the same for all membranes evaluated in this study. The presence of the sodium sulfate in the solution practically saturated in sodium chloride and the minor resistance for sodium chloride transport through the membrane thus leads to salting-out of sodium chloride from the retentate to the permeate. Since the concentration difference of sulfate between retentate and permeate is the driving force for salting-out of sodium chloride from the retentate to the 
permeate, a relation between chloride retention and the difference in sulfate concentration between retentate and permeate is obtained, independent of the nanofiltration membrane used. The only effect of the membrane on the distribution of sodium chloride and sodium sulfate over retentate and permeate is caused by the sulfate retention of the membrane, which is directly related to the pore radius obtained during membrane characterization, and to a minor extent by the $\mathrm{NaCl}$ transport resistance.

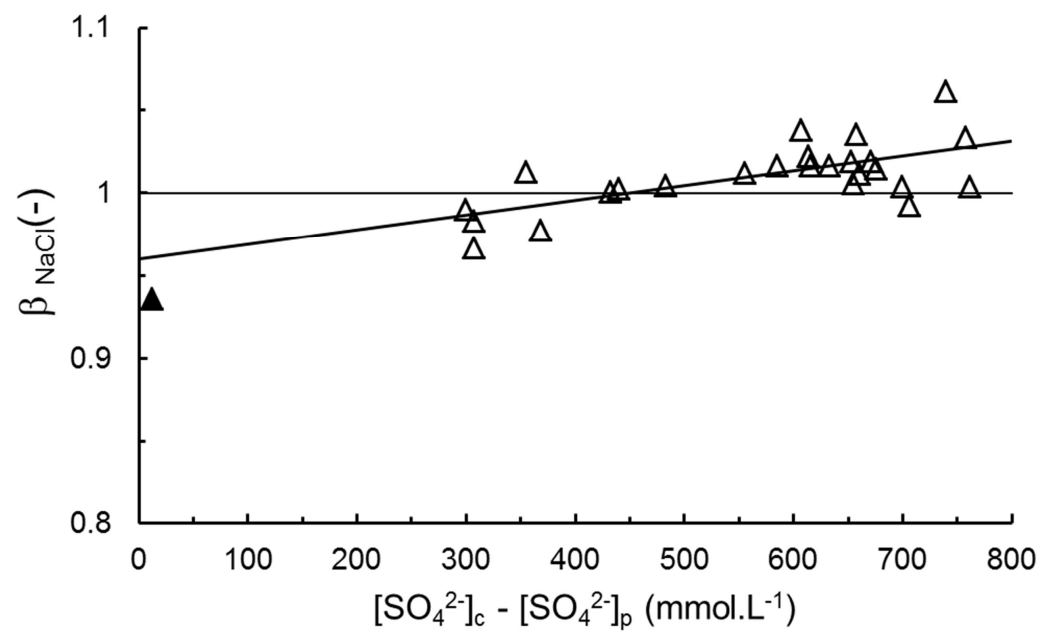

Figure 8: $\quad$ Sodium chloride concentration ratio $\beta$ NaCl for Desal $5 \mathrm{DK}$ as function of the difference in sulfate concentration between concentrate and permeate. The filled symbols represents the result for processing of raw salt solution originating from Mariager and open symbols represent mother liquor brines originating from Delfzijl as obtained from [5].

When the concentration product ratio $\beta_{\mathrm{NaCl}}$ is related to the pore radius of the individual membranes obtained during the characterization procedure, it furthermore becomes clear that $\beta_{\mathrm{NaCl}}$ increases linearly from 0.9 for the most tight nanofiltration membranes to 1 for the most open nanofiltration membranes (see Fig. 9). This trend can be explained by slight changes in the resistance for $\mathrm{NaCl}$ transport (which gets slightly lower when more open membranes are used), in combination with relatively low sodium sulfate retention for the relatively open nanofiltration membranes. In contrast to the sodium chloride retentions obtained during characterization experiments using a $1 \mathrm{~g} . \mathrm{L}^{-1}$ model 
solution, the membrane material used does not have an effect on sodium chloride retention for processing of practically saturated salt solution. This is due to the very high ionic strength of the practically saturated raw salt solution, leading to negligible contribution of the membrane charge density. Thus mainly pore size is important for sodium chloride retention (sieving effect), since the Donnan exclusion contribution for processing of practically saturated salt solutions is negligible. Furthermore, the lower the sulfate retention becomes during processing of the raw salt solution, the closer the activity coefficient ratio for permeate over concentrate to 1 , and the more similar the molar volumes for concentrate and permeate become. Consequently, since these contributions mainly cause the difference in chemical equilibrium of $\mathrm{NaCl}$ between retentate and permeate, the concentration product ratio for more open membranes is expected to be closer to 1 than that for more tight membranes.

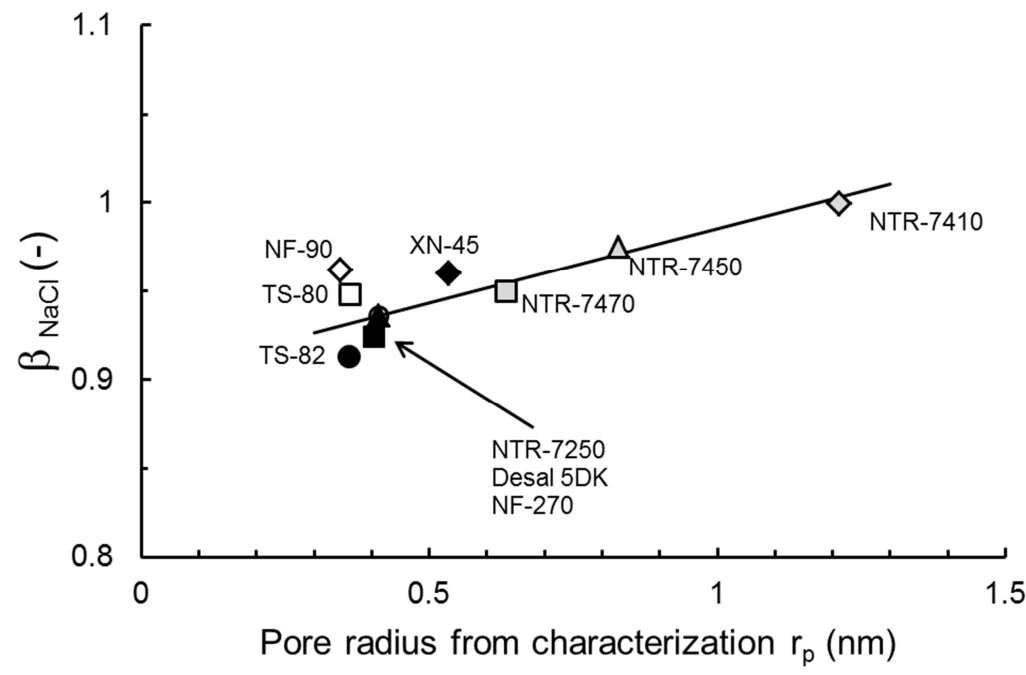

Figure 9: $\quad$ Sodium chloride concentration ratio $\beta_{\mathrm{NaCl}}$ for all evaluated membranes during processing of practically saturated raw salt solution originating from Mariager as function of pore radius determined during membrane characterization with model solutions.

When the retention results for nanofiltration of mother liquor brine (with a relatively high sulfate concentration in the salt solution) using NF-270 (not shown, but similar results as for Desal 5DK are obtained) and Desal 5DK as reported in [5] are translated into sodium concentration ratios $\beta_{\mathrm{NaCl}}$, it is clear that the sodium chloride concentration ratio 
$\beta_{\mathrm{NaCl}}$ increases with a strong increase in the sulfate concentration difference (see Fig. 8). At high concentration differences even values in excess of 1 are obtained. This increase in $\beta_{\mathrm{NaCl}}$ is not caused by significant changes in membrane resistance for $\mathrm{NaCl}$ transport, but by the fact that the activity coefficients ratio $\left(\gamma_{\mathrm{Na}}{ }^{+} \cdot \gamma_{\mathrm{Cl}^{-}}\right)_{\mathrm{C}} /\left(\gamma_{\mathrm{Na}^{+}}{ } \cdot \gamma_{\mathrm{Cl}}\right)_{\mathrm{p}}$ increases at higher sulfate concentration difference and the ratio $\left(\mathrm{V}_{\mathrm{m}, \mathrm{c}} / \mathrm{V}_{\mathrm{m}, \mathrm{p}}\right)^{2}$ of molar volumes of concentrate over permeate solutions starts to differ from 1 . Since the activity ratio $\left(\mathrm{a}_{\mathrm{Na}}+. \mathrm{a}_{\mathrm{Cl}}\right)_{\mathrm{c}} /\left(\mathrm{a}_{\mathrm{Na}}+. \mathrm{a}_{\mathrm{Cl}}\right)_{\mathrm{p}}$ remains constant at unchanged membrane resistance, the sodium chloride concentration ratio $\beta_{\mathrm{NaCl}}=\left(\left[\mathrm{Na}^{+}\right]_{\mathrm{p}} \cdot\left[\mathrm{Cl}_{\mathrm{p}}\right]_{\mathrm{p}}\right) /\left(\left[\mathrm{Na}^{+}\right]_{\mathrm{c}} \cdot\left[\mathrm{Cl}^{-}\right]_{\mathrm{c}}\right)$ needs to increase, and values slightly in excess of 1 can be obtained as well.

Consequently, the sulfate retention during nanofiltration of almost saturated salt solutions depends on the openness of the nanofiltration membrane and is a function of the pore radius determined from membrane characterization experiments using a model solution containing a single neutral solute. The chloride retention for nanofiltration membranes can subsequently be determined quite accurately from the sulfate concentration difference between retentate and permeate, which is a function of the sulfate retention, irrespective of whether open or tight nanofiltration membranes have been used. This means that for practically saturated sodium chloride solutions, a methodology has been developed to predict sodium chloride and sodium sulfate retentions from the pore radius of the nanofiltration membrane determined in a simple characterization experiment. An explanation for the relation between these variables has been given on the basis of thermodynamic considerations. It has furthermore been shown that this relation holds since for these salt solutions practically saturated in sodium chloride the resistance for sodium chloride transport is negligible and the activity coefficients ratio for permeate over retentate is close to one.

\section{Conclusions}

During nanofiltration of practically saturated raw salt solutions obtained from solution mining, the sulfate retention can be estimated from the mean pore radius of the nanofiltration membrane as determined from simple characterization experiments. For all nanofiltration membranes, ranging from tight to relatively open, the sulfate retention obtained for nanofiltration of raw salt solutions is lower than that obtained during characterization experiments with a single salt sodium sulfate solution at similar sulfate concentration. This reduction is due to the presence of sodium chloride in the solution. It is ascribed to the lower sulfate radius over mean pore radius at high ionic strength of 
the solution and possibly reduced Donnan exclusion. As a first estimate, the chloride retention of the nanofiltration membranes for processing of practically saturated salt solutions, irrespective of the openness of the membrane, can be obtained from the difference in sulfate concentration between concentrate (retentate) and permeate. This difference can be obtained from the sulfate retention and therefore indirectly from the mean pore radius obtained from characterization experiments. The fact that this correlation is practically independent of the membrane type used is caused by the low restriction of the membrane for sodium chloride transport and the negligible difference in activity coefficient for sodium chloride between concentrate and permeate, as indicated by thermodynamic considerations. This is illustrated by the ratio of the concentration product for sodium chloride for permeate over concentrate, which is between 0.9 and 1 for all membranes. This ratio is linearly dependent on the pore radius of the nanofiltration membrane as obtained from the characterization and is relatively small for the tightest membranes, indicating that the membrane resistance for transport of sodium chloride is slightly higher than for more open membrane, as expected. At high sulfate concentration differences between concentrate and permeate as obtained for nanofiltration of mother liquor brine, sodium chloride concentration ratios in excess of 1 can be obtained as a consequence of changes in activity coefficients and molar volumes of the solutions. The ratio of the permeance for raw salt solution over pure water drops from 0.55 (as expected on the basis of the bulk viscosity ratio) for the most open membranes to much lower values for tighter nanofiltration membranes. This phenomenon may be caused by viscosity changes in small pores or by a change in effective membrane porosity during permeation conditions.

\section{Acknowledgement}

The authors would like to thank Prof. Matthias Wessling for fruitful discussions.

\section{Nomenclature}

\begin{tabular}{|c|c|c|}
\hline$a$ & activity & $\mathrm{mol} \mathrm{m}^{-3}$ \\
\hline$A_{k}$ & porosity of the membrane & \\
\hline$C_{c}$ & concentration in the concentrate (retentate) & $\mathrm{mol} \mathrm{m}^{-3}$ \\
\hline$c_{i}$ & $\begin{array}{l}\text { concentration of component } i \text { in the membrane } \\
\text { concentration of component } i \text { on the feed side of the }\end{array}$ & $\mathrm{mol} \mathrm{m}^{-3}$ \\
\hline$C_{i, m}$ & $\begin{array}{l}\text { membrane } \\
\text { concentration of component } i \text { on the permeate side of the }\end{array}$ & $\mathrm{mol} \mathrm{m}^{-3}$ \\
\hline$C_{i, p}$ & membrane & $\mathrm{mol} \mathrm{m}^{-3}$ \\
\hline$C_{p}$ & concentration in the permeate & $\mathrm{mol} \mathrm{m}^{-3}$ \\
\hline
\end{tabular}




\begin{tabular}{|c|c|c|}
\hline$D_{\infty}$ & diffusivity of the solute & $\mathrm{m}^{2} \mathrm{~s}^{-1}$ \\
\hline$D_{i, \infty}$ & bulk diffusivity of solute i & $\mathrm{m}^{2} \mathrm{~s}^{-1}$ \\
\hline$D_{i, p}$ & hindered diffusivity & $\mathrm{m}^{2} \mathrm{~s}^{-1}$ \\
\hline$d x$ & differential distance normal to membrane & \\
\hline$F$ & Faraday constant & $\mathrm{C} \mathrm{mol}{ }^{-1}$ \\
\hline G & hydrodynamic enhanced lag coefficient & \\
\hline$J$ & volume flux & $m^{3} m^{-2} s^{-1}$ \\
\hline$j_{i}$ & flux of component $i$ & $\mathrm{~mol} \mathrm{~m}^{-2} \mathrm{~s}^{-1}$ \\
\hline $\begin{array}{l}J_{w} / \Delta P \\
k\end{array}$ & $\begin{array}{l}\text { pure water permeance } \\
\text { mass transfer constant }\end{array}$ & $\mathrm{m} \mathrm{s}^{-1} \mathrm{kPa}^{-1}$ \\
\hline$K^{-1}$ & hydrodynamic enhanced drag coefficient & \\
\hline$K_{i, c}$ & hindrance factor for convection & \\
\hline$K_{i, d}$ & hindrance factor for diffusion & \\
\hline$P$ & pressure & $\mathrm{Pa}$ \\
\hline$P_{c}$ & concentrate pressure & $\mathrm{Pa}$ \\
\hline$P_{p}$ & permeate pressure & $\mathrm{Pa}$ \\
\hline$P_{0}$ & pressure at reference state & $\mathrm{Pa}$ \\
\hline$P e_{m}$ & Peclet number & \\
\hline Perm $_{w}$ & pure water permeance $\left(J_{w} / \Delta P\right)$ & $\mathrm{m} \mathrm{s}^{-1} \mathrm{kPa}^{-1}$ \\
\hline Perm $_{\text {brine }}$ & salt solution permeance $\left(J_{\text {brine }} /(\Delta P-\Delta \Pi)\right.$ & $\mathrm{m} \mathrm{s}^{-1} \mathrm{kPa}^{-1}$ \\
\hline$R_{o b s}$ & observed rejection & \\
\hline$r_{p}$ & mean pore radius & $\mathrm{m}$ \\
\hline$R_{\text {real }}$ & real rejection & \\
\hline$r_{s}$ & solute Stokes radius & $\mathrm{m}$ \\
\hline$T$ & temperature & $\mathrm{K}$ \\
\hline$T_{c}$ & concentrate temperature & $\mathrm{K}$ \\
\hline$T_{p}$ & permeate temperature & $\mathrm{K}$ \\
\hline$u$ & diffusive velocity & $\mathrm{m} \mathrm{s}^{-1}$ \\
\hline$x$ & mole fraction & \\
\hline$x_{C l}$ & chloride ion fraction & \\
\hline$x_{\mathrm{Na}}^{+}$ & sodium ion fraction & \\
\hline$\Delta x$ & membrane thickness & $\mathrm{m}$ \\
\hline$v$ & solute velocity & $\mathrm{m} \mathrm{s}^{-1}$ \\
\hline$V_{m}$ & molar volume & $\mathrm{L} \mathrm{mol}^{-1}$ \\
\hline$z_{i}$ & ion valency & \\
\hline \multicolumn{3}{|l|}{ Greek } \\
\hline & concentration product ratio of $[\mathrm{Na}] .[\mathrm{Cl}]$ for permeate over & \\
\hline$\beta$ & retentate & \\
\hline$\gamma$ & molal activity coefficient & \\
\hline$\delta$ & film thickness & $\mathrm{m}$ \\
\hline$\Delta l$ & distance & $\mathrm{m}$ \\
\hline$\Delta P$ & pressure difference & $\mathrm{Pa}$ \\
\hline
\end{tabular}




\begin{tabular}{|c|c|c|}
\hline$\Delta \mu$ & chemical potential drop or difference & $\mathrm{J} \mathrm{mol}^{-1}$ \\
\hline$\Delta \mu_{\mathrm{membr}}$ & $\begin{array}{l}\text { chemical potential drop due to resistance of the membrane } \\
\text { (including } \\
\text { resistances due to concentration polarization) }\end{array}$ & $\mathrm{J} \mathrm{mol}^{-1}$ \\
\hline$\Delta \Pi$ & osmotic pressure difference & $\mathrm{Pa}$ \\
\hline$\zeta_{i, j}$ & friction between solute $\mathrm{i}$ and $\mathrm{j}$ & \\
\hline$\eta$ & viscosity of solution & $\mathrm{kPa} \mathrm{s}$ \\
\hline$\lambda$ & ratio of solute to pore radius & \\
\hline$\mu$ & chemical potential & $\mathrm{J} \mathrm{mol}^{-1}$ \\
\hline$\mu^{*}$ & chemical potential of component in solution at reference state & $\mathrm{J} \mathrm{mol}^{-1}$ \\
\hline$\Phi$ & steric partitioning term & \\
\hline$\Psi$ & electrical potential & $\mathrm{V}$ \\
\hline
\end{tabular}

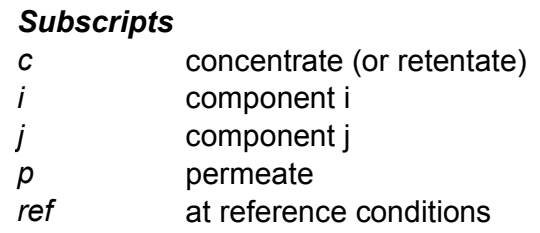

\section{References}

[1] A.I. Schafer, A.G. Fane, T.D. Waite (Eds), Nanofiltration - Principles and Applications, Elsevier Ltd., Oxford, UK, 2005.

[2] M. Milosevic, K.J.J. Staal, G. Bargeman, B Schuur, A.B. de Haan, Fractionation of aqueous sodium salts by liquid-liquid extraction in aqueous two phase systems, Separation and Purification Technology 125 (2014) 208-215.

[3] D. Bessarabov, Z. Twardowski, Industrial application of nanofiltration - new perspectives, Membrane Technology 9 (2002) 6-9.

[4] W.M. Samhaber, H. Schwaiger, The application of nanofiltration in the salt industry, 14th International Congress of Chem. and Proc. Eng. (CHISA 2000), Prague, August 2000.

[5] G. Bargeman, M. Steensma, A. ten Kate, J.B. Westerink, R.L.M. Demmer, H. Bakkenes, C.F.M. Manuhutu, Nanofiltration as energy-efficient solution for sulfate waste in vacuum salt production, Desalination 245 (2009) 460-468.

[6] A. Pérez-González, R. Ibáñez, P. Gómez, A.M. Urtiaga, I. Ortiz, J.A. Irabien, Nanofiltration separation of polyvalent and monovalent anions in desalination brines, J. Membr. Sci. 473 (2015) 16-27. 
[7] A, Pérez-González, R. Ibáñez, P. Gómez, A. Urtiaga, I. Ortiz, Integration of nanofiltration for the sustainable management of reverse osmosis brines Chem. Eng. Trans. 39 (2014) 85-90.

[8] W.R. Bowen, A.W. Mohammad, N. Hilal, Characterization of nanofiltration membranes for predictive purposes- use of salts, uncharged solutes and atomic force microscopy, J. Membr. Sci. 126 (1997) 91-105.

[9] J. Schaep, C. Vandecasteele, A. W. Mohammad, W.R. Bowen, Modelling the retention of ionic components for different nanofiltration membranes, Separation and Purification Technology 22-23 (2001) 169-179.

[10] G. Bargeman, J.M. Vollenbroek, J. Straatsma, C.G.P.H. Schoën, R.M. Boom, Nanofiltration of multi-component feeds. Interactions between neutral and charged components and their effect on retention, J. Membr. Sci. 247 (2005) 1120.

[11] J. Straatsma, G. Bargeman, H.C. van der Horst, J.A. Wesselingh, Can nanofiltration be fully predicted by a model?, J. Membr. Sci. 198 (2002) 273-284.

[12] T.R. Noordman, J.A. Wesselingh, Transport of large molecules through membranes with narrow pores, The Maxwell-Stefan description combined with hydrodynamic theory, J. Membr. Sci. 210 (2002) 227-243.

[13] K. Thomsen, Thermodynamics of electrolyte systems of industry in T.M. Letcher (ed.) Chemical Thermodynamics for Industry (2004) 227, Royal Society of Chemistry.

[14] Y. Yoon, G. Amy, J. Cho, N. Her, Effects of retained natural organic matter (NOM) on NOM rejection and membrane flux decline with nanofiltration and ultrafiltration, Desalination 173 (2005) 209-221.

[15] S. Lee, C-H. Lee, Effect of membrane properties and pretreatment on flux and NOM rejection in surface water nanofiltration, Separation and Purification Technology 56 (2007) 1-8.

[16] K. Boussu, C. Vandecasteele, B. Van der Bruggen, Relation between membrane characteristics and performance in nanofiltration, J. Membr. Sci. 310 (2008) 5165.

[17] R. Schlesinger, G. Götzinger, H. Sixta, A. Friedl, M. Harasek, Evaluation of alkali resistant nanofiltration membranes for the separation of hemicellulose from concentrated alkaline process liquors, Desalination 192 (2006) 303-314. 
[18] A. Gautam, T.J. Menkhaus, Performance evaluation and fouling analysis for reverse osmosis and nanofiltration membranes during processing of lignocellulosic biomass hydrolysate, J. Membr. Sci. 451 (2014) 252-265.

[19] J. Luo, Y. Wan, Effects of $\mathrm{pH}$ and salt on nanofiltration - a critical review J. Membr. Sci. 438 (2013) 18-28.

[20] H.C. van der Horst, J.M.K. Timmer, T. Robbertsen, J. Leenders, Use of nanofiltration for concentration and demineralization in the dairy industry: model for mass transport, J. Membr. Sci. 104 (1995) 205-218.

[21] W.M. Haynes, Handbook of Chemistry and Physics, $94^{\text {th }}$ edition 2013-2014

[22] G. Bargeman, J.B. Westerink, O. Guerra Miguez, M. Wessling, The effect of $\mathrm{NaCl}$ and glucose concentration on retentions for nanofiltration membranes processing concentrated solutions, Separation and Purification Technology 134 (2014) 46-57.

[23] K. Kosutic, D. Dolar, B. Kunst, On experimental parameters characterizing the reverse osmosis and nanofiltration memrbanes' active layer, J. Membr. Sci. 282 (2006) 109-114.

[24] M. Nystrom, L. Kaipia and S. Luque, Fouling and retention of nanofiltration membranes, J. Membr. Sci. 98 (1995), 249-262.

[25] M.D. Afonso, G. Hagmeyer and R. Gimbel, Streaming potential measurements to assess the variation of nanofiltration membranes surface charge with the concentration of salt solutions, Separation and Purification Technology, 22-23 (2001) 529-541.

[26] C.Y. Tang, Y-N. Kwon, J.O. Leckie, Effect of membrane chemistry and coating layer on physiochemical properties of thin film composite polyamide $\mathrm{RO}$ and $\mathrm{NF}$ membranes I. FTIR and XPS characterization of polyamide and coating layer chemistry, Desalination 242 (2009) 149-167

[27] C.Y. Tang, Y-N. Kwon, J.O. Leckie, Effect of membrane chemistry and coating layer on physiochemical properties of thin film composite polyamide $\mathrm{RO}$ and $\mathrm{NF}$ membranes II. Membrane physiochemical properties and their dependence on polyamide and coating layers, Desalination 242 (2009) 168-182.

[28] J. Kestin, H.E. Khalifa, R.J. Correia, Tables of the dynamic and kinematic viscosity of aqueous $\mathrm{NaCl}$ solutions in the temperature range 20-150 C and pressure range 0.1-35 MPa, J. Phys. Chem. Ref. Data 10 (1981) 71-87 
[29] W.R. Bowen, J.S. Welfoot, Modelling the performance of membrane nanofiltration-critical assessment and model development, Chem. Eng. Sci. 57 (2002) 1121-1137.

[30] A. Bouchoux, H. Roux-de Balmann, F. Lutin, Nanofiltration of glucose and sodium lactate solutions Variations of retentions between single- and mixedsolute solutions, J. Membr. Sci. 258 (2005) 123-132. 


\section{Chapter 6}

Conclusions and recommendations 


\section{Conclusions}

In Chapter 2 it is shown that for several commercially available nanofiltration membranes the addition of salt ions to a glucose solution can result in reduction of the glucose retention, even at low salt concentrations. The reduction in glucose retention is membrane specific, and furthermore depends on the retention of the salt ion added. A relatively low retention for the salt results in a higher decrease in glucose retention. For addition of $\mathrm{NaCl}, \mathrm{CaCl}_{2}$, and $\mathrm{KCl}$ to the glucose solution, the retention drop is a function of the $\mathrm{Cl}^{-}$concentration in the permeate for the nanofiltration membranes Desal 5DK and NF. This function is independent of the cation used. The observed effect is important for prediction of membrane performance during the demineralization of sugar solutions. However, it is not well described by a predictive model on the basis of the Maxwell-Stefan equation, which uses only pore size exclusion, Donnan exclusion, and average pore size to describe the separation process. The reduced glucose retention in the presence of salt can be described well when the pore radius value substituted in the model is increased. Several hypotheses are available to explain the observed phenomenon. An example is that the glucose retention reduction is caused by an increased effective average pore size, as a consequence of higher repulsion forces between the double layers in the pores when the concentration of ions and therefore the membrane charge, as is predicted by the model, is increased. Another possible explanation is the presence of a pore size distribution. The Maxwell-Stefan model shows that the addition of salt with relatively low retention reduces the flux of the small pores to a higher extent than the larger pores. Thus the retention of glucose is determined to a larger extent by the larger pores and reduces when salt is added. This explains why in experiments where salts with low retention characteristics are present, the glucose retention drop is relatively large and a larger pore size estimate in the Maxwell-Stefan model is required to predict the glucose retention more accurately.

In Chapter 3 results from nanofiltration of aqueous solutions containing $\mathrm{NaCl}$ in concentrations between $1 \mathrm{~g} . \mathrm{L}^{-1}$ and $300 \mathrm{~g} \cdot \mathrm{L}^{-1}$ and glucose concentrations as high as 80 g. $\mathrm{L}^{-1}$ are reported using NF 270, NTR 7450, NP030, Desal 5 DK and Desal $5 \mathrm{HL}$ membranes. Extending the sodium chloride concentration range in the glucose solution from 58.5 g. $\mathrm{L}^{-1}$ (as maximally used in the study reported in Chapter 2) to almost 300 $\mathrm{g} \cdot \mathrm{L}^{-1}$ shows that the glucose retention for solutions containing $1 \mathrm{~g} \cdot \mathrm{L}^{-1}$ glucose decreases strongly when the $\mathrm{NaCl}$ concentration is increased from $0 \mathrm{~g} \cdot \mathrm{L}^{-1}$ to $100 \mathrm{~g} \cdot \mathrm{L}^{-1}$, when 
compared at similar flux. As in the study reported in Chapter 2 a change in the pore radius at assumed constant glucose radius or alternatively a change in the ratio of glucose molecular radius over the membrane effective pore radius explains the obtained results. A further increase in $\mathrm{NaCl}$ concentration results in slight further reductions of the glucose retentions and consequently slightly higher mean pore radii. This means that the effect of adding salt to the glucose solution stabilized at higher salt concentration. At very high glucose concentrations (of around $80 \mathrm{~g} \cdot \mathrm{L}^{-1}$ ) in the feed solution and $\mathrm{NaCl}$ concentrations in excess of $175 \mathrm{~g} \cdot \mathrm{L}^{-1}$, the $\mathrm{NaCl}$ retention is around 0 for all membranes evaluated, and is only slightly affected by the difference in glucose concentration between retentate and permeate. The presence of glucose only has a minor salting-out effect on $\mathrm{NaCl}$, leading to slightly negative $\mathrm{NaCl}$ retentions for high glucose concentrations. For mixed glucose and $\mathrm{NaCl}$ solutions containing $\mathrm{NaCl}$ concentrations higher than $90 \mathrm{~g} . \mathrm{L}^{-1}$, an increase in glucose concentration from $1 \mathrm{~g} . \mathrm{L}^{-1}$ to $80 \mathrm{~g} . \mathrm{L}^{-1}$ does not affect the glucose retention at the same flux for NF 270, Desal 5DK, Desal $5 \mathrm{HL}$ and NP 030. However, at the same operating pressure an increase in glucose concentration from $1 \mathrm{~g} \cdot \mathrm{L}^{-1}$ to $80 \mathrm{~g} \cdot \mathrm{L}^{-1}$ results in significantly lower glucose retentions due to the lower flux at higher glucose concentrations. For solutions containing 1 g. $\mathrm{L}^{-1}$ glucose and $\mathrm{NaCl}$ concentrations of $100 \mathrm{~g} \cdot \mathrm{L}^{-1}$ and higher, the membrane flux has a significant influence on the $\mathrm{NaCl}$ retention. For all membranes evaluated mean pore radii and effective membrane thicknesses have been determined. Changes in the pore radii and effective diameters can be explained by hypotheses proposed in earlier studies. The obtained parameters can be used to facilitate the development of nanofiltration applications for desalination of concentrated glucose solutions in industry and to get a feel for changing membrane characteristics for solutions with high salt concentrations.

In Chapter 4 it is shown that the use of nanofiltration for the production of brines supersaturated in sodium sulfate is a technically feasible and attractive alternative for evaporative of cooling concentration. Crystallization of sodium sulfate in the membrane modules can be avoided by the presence of a primary nucleation inhibitor in the feed to the nanofiltration unit. Sodium sulfate crystallization can be induced in a separate crystallizer outside of the membrane unit by addition of crystal seeds. NF270 is a suitable membrane for this application and is preferred over Desal DK, Desal DL, TS-80 and MPF-34. Chloride and bromide retentions are negative and they are a function of the difference in sulfate concentration between concentrate and permeate. Carbonate 
retentions are linearly dependent on sulfate retentions. Calcium retention for NF270 is in excess of $95 \%$ and proven to be stable during 1200 hours of continuous operation. The same applies for the potassium retention albeit at a lower level of $10 \%$.

During nanofiltration of practically saturated raw salt solutions obtained from solution mining, the sulfate retention can be estimated from the mean pore radius of the nanofiltration membrane as determined from simple characterization experiments as shown in Chapter 5. For all nanofiltration membranes, ranging from tight to relatively open, the sulfate retention obtained for nanofiltration of raw salt solutions is lower than that obtained during characterization experiments with a single salt sodium sulfate solution at similar sulfate concentration. This reduction is due to the presence of sodium chloride in the solution. Based on results obtained in Chapters 2 and 3 this phenomenon is ascribed to the lower sulfate radius over mean pore radius at high ionic strength of the solution and possibly reduced Donnan exclusion. As a first estimate, the chloride retention of the nanofiltration membranes for processing of practically saturated salt solutions, irrespective of the openness of the membrane, can be obtained from the difference in sulfate concentration between concentrate (retentate) and permeate. This is in line with results shown in Chapter 4 for nanofiltration of solutions saturated in sodium chloride and containing much higher sodium sulfate concentrations, using NF270 and Desal DK membranes. This difference in sodium sulfate concentration between retentate and permeate can be obtained from the sulfate retention and therefore indirectly from the mean pore radius obtained from characterization experiments. The fact that this correlation is practically independent of the membrane type used is caused by the low restriction of the membrane for sodium chloride transport and the negligible difference in activity coefficient for sodium chloride between concentrate and permeate, as indicated by thermodynamic considerations. This is illustrated by the ratio of the concentration product for sodium chloride for permeate over concentrate, which is between 0.9 and 1 for all membranes. This ratio is linearly dependent on the pore radius of the nanofiltration membrane as obtained from the characterization and is relatively low for the tightest membranes, indicating that the membrane resistance for transport of sodium chloride is slightly higher than for more open membrane, as expected. At high sulfate concentration differences between concentrate and permeate as obtained for nanofiltration of mother liquor brine, sodium chloride concentration ratios in excess of 1 can be obtained as a consequence of changes in activity coefficients and molar volumes of the solutions. 
The results obtained and reported in this thesis consequently provide a better insight in the effect of salt ions on glucose retention and vice versa during processing of solutions containing both components. Furthermore, this has led to improved insight in the transport process through the nanofiltration membranes. In addition, nanofiltration of saturated salt solutions has been shown to be feasible. Even nanofiltration operation with solutions super-saturated in a soluble salt such as sodium sulfate is shown to be possible. During nanofiltration of these solutions retentates and permeates practically saturated in sodium chloride are obtained. Sulfate and chloride retentions for nanofiltration membranes can now be determined from a simple membrane characterization method and thermodynamic considerations.

\section{Recommendations}

Despite the progress that has been made in explaining the effect of the presence of salt ions during nanofiltration of glucose containing aqueous solutions, there is still a lot of study needed to fully unravel the fundamental background of the observed phenomena. In the current work several hypothesis have been put forward which may explain the observations and the phenomena occurring. However, despite targeted approaches to get full understanding of the phenomena occurring, both in the work presented in this thesis and the work performed by several other authors as cited in chapters 2 and 3 , the real phenomenon or combinations of phenomena occurring have not yet been proven completely. This leaves room for further investigations. One of the techniques that can assist in getting a better insight in the effects hypothesized to occur is the use of in-situ ellipsometry [1]. With this technique a better insight can be created in membrane swelling during nanofiltration operation. Furthermore, the fundamental work performed so far has mainly focused on retention of glucose during nanofiltration. It is not unlikely that for ultrafiltration operation the retention of neutral components that normally retained well (e.g. bigger polyethylene glycols) is affected by the presence of salt in the solution as well. This leaves room for further investigations as well.

For practically saturated sodium chloride solutions a proper description of retention behavior for sodium chloride and sodium sulfate has been developed in the studies reported in this thesis. However, it would be very helpful to extend this approach to 
concentrated, but unsaturated sodium chloride solutions such as used in depleted chlor/alkali brine and seawater. This would facilitate the design of nanofiltration units for these applications. Furthermore, it would be very valuable to extend this work to other saturated solutions to facilitate the development of other applications and to facilitate the design of membrane installations for these applications.

\section{References}

[1] W. Ogieglo, H. Wormeester, K.-J. Eichhorn, M. Wessling, N.E. Benes, In situ ellipsometry studies on swelling of thin polymer films: A review, Progress in Polymer Science 42 (2015) 42-78. 


\section{Acknowledgement}

When you are more than 50 years old, you have learned a lot of things in your life from many different people, such as your colleagues, friends and family. You owe gratitude to all of them for teaching you something, giving you a different perspective on life or your work, or just allowing you to enjoy life together with them. This makes it undoable for me to mention all people that need to be thanked for enriching my life. Therefore, for all persons who believe that they have made a positive contribution to my development, my work or my private life, I would like to express my sincere gratitude to you and I hope that you will keep on contributing to my life in a positive way.

Still, I do want to make an exception for some special people who have been an important part of my life for almost two decades or more, and mention and thank them specifically. Bob for his long lasting friendship and for cheering up my life during our Friday evening music sessions. My family in law, who you always can rely on when you need them. Heleen, my sister, who I admire for her strong feeling for justice and her courage to speak up despite the consequences for her personal life. My mother, who not only gave me birth but who was always there when I needed her. My father, who raised my interest in science, politics and sports. I still miss you a lot. Dennis, Edwin and Michel, my three grown-up sons, with their own unique personality and strong points. I love you. You have given me so much joy in life and I am extremely proud to be your father. Last but not least, Janine. In my eyes your contribution to society is much more important and valuable than mine. You have saved people's lives and have taken care of the sick and dying without asking anything in return. You are always there for me, giving me good advice. I love you with all of my heart. 


\section{Publications and Patents}

Peer Reviewed Journal Publications

- $\quad$ A.A. Kiss, J.J. Pragt, H.J. Vos, G. Bargeman, M.T. de Groot, Enhanced process for methanol production by $\mathrm{CO}_{2}$ hydrogenation, Comp. Aided Chem. Eng. 38 (2016) 985-990.

- A.A. Kiss, J.J. Pragt, H.J. Vos, G. Bargeman, M.T. de Groot, Novel efficient process for methanol synthesis by $\mathrm{CO}_{2}$ hydrogenation, Chem. Eng. J. 284 (2016) 260-269.

- G. Bargeman, J.B. Westerink, C.F.H. Manuhutu, A. ten Kate, The effect of membrane characteristics on nanofiltration membrane performance during processing of practically saturated salt solutions, J. Membr. Sci. 485 (2015) 112-122.

- $\quad$ K.P. Lee, J. Zheng, G. Bargeman, A.J.B. Kemperman, N.E. Benes, pH stable thin film composite polyamine nanofiltration membranes by interfacial polymerization, J. Membr. Sci. 478 (2015) 75-84.

- G. Bargeman, J.B. Westerink, O. Guerra Miguez and M. Wessling, The effect of $\mathrm{NaCl}$ and glucose on retentions for nanofiltration membranes processing concentrated solutions, Sep. Purif. Technol. 134 (2014) 46-57.

- M. Milosevic, K.J.J. Staal, G. Bargeman, B. Schuur, A.B. de Haan, Fractionation of aqueous sodium salts by liquid-liquid extraction in aqueous two phase systems, Sep. Purif. Technol. 125 (2014) 208-215.

- M.T.G. Jongmans, A. Londono, S. Babu Mamilla, H. Pragt, K. Aaldering, G. Bargeman, M. Nieuwhof, A. ten Kate, P. Verwer, T. Kiss, C. van Strien, B. Schuur, A.B. de Haan, Extractant screening for the separation of dichloroacetic acid from monochloroacetic acid by extractive distillation, Sep. Purif. Technol. 98 (2012) 206215.

- M. Dalwani, G. Bargeman, S. Hosseiny, M. Boerrigter, M. Wessling, N. Benes, Sulfonated poly (ether ether ketone) based composite membranes for nanofiltration of acidic and alkaline media, J. Membr. Sci. 381 (2011) 81-89.

- M.T. de Groot, R. de Rooij, A.A.C.M. Bos, G. Bargeman, Bipolar membrane electrodialysis for the alkanization of ethanolamine salts. The effect of the operation mode and feed composition on proton tunnelling and current utilization, J. Membr. Sci. 378 (2011) 415-424. 
- M. Dalwani, N.E. Benes, G. Bargeman, D. Stamatialis, M. Wessling, Effect of pH on the performance of polyamide/polyacrylonitrile based thin film composite membranes, J. Membr. Sci. 372 (2011) 228-238.

- M.T. de Groot, A.A.C.M. Bos, A. Peris Lazaro, R. de Rooij, G. Bargeman, Electrodialysis for the concentration of ethanolamine salts, J. Membr. Sci. 371 (2011) 75-83.

- P. Domínguez de María, P. Bracco, L. Fernando Castelhano and G. Bargeman, Influence of the organocatalyst in the Aldol/Mannich-type product selectivities in C-C bond forming reactions, ACS Catal. 1 (2011) 70-75.

- M. Dalwani, N.E. Benes, G. Bargeman, D. Stamatialis, M. Wessling, A method for characterizing membranes during nanofiltration at extreme $\mathrm{pH}$, J. Membr. Sci. 363 (2010) 188-194.

- P. Domínguez de María, E. Fernández-Álvaro, A. ten Kate, G. Bargeman, Role of apparent pKa of carboxylic acids in lipase-catalyzed esterifications in biphasic systems, J. Molec. Cat. B: Enz. 59 (2009) 220-224.

- G. Bargeman, M. Steensma, A. ten Kate, J.B. Westerink, R.L.M. Demmer, H. Bakkenes and C.F.M. Manuhutu, Nanofiltration as energy-efficient solution for sulfate waste in vacuum salt production, Desalination 245, 1-3 (2009) 460-468.

- P. Domínguez de María, C. García-Burgos, G. Bargeman, R.W. van Gemert, Pig Liver Esterase (PLE) as Biocatalyst in Organic Synthesis: From Nature to Cloning and Practical Applications, Review, Synthesis 10 (2007) 1439-1452.

- C. Carboni-Oerlemans, P. Domínguez de María, B. Tuin, G. Bargeman, A. van der Meer, R. van Gemert, Hydrolase-catalysed synthesis of peroxycarboxylic acids: Biocatalystic promiscuity for practical applications, J. Biotechnol. 126 (2006) 140-151.

- P. Domínguez de María, C. Carboni-Oerlemans, B. Tuin, G. Bargeman, A. van der Meer, R. van Gemert, Biotechnological Applications of Candida antartica lipase A: State of the Art, J. Molec. Cat. B: Enz. 37 (2005) 36-46.

- G. Bargeman, J.M. Vollenbroek, J. Straatsma, C.G.P.H. Schroën, R.M. Boom, Nanofiltration of multi-component feeds. Interactions between neutral and charged components and their effect on retention, J. Membr. Sci. 247 (2005) 11-20.

- G. Bargeman, G.H. Koops, J. Houwing, I. Breebaart, H.C. van der Horst, M. Wessling, The development of electro-membrane filtration for the isolation of valuable charged components, Chemie Ingenieur Technik 74 (5) (2002) 639-640. 
- G. Bargeman, J. Houwing, I. Recio, G.H. Koops and H.C. van der Horst, Electromembrane filtration for the selective isolation of bio-active peptides from an as2casein hydrolysate, Biotechn. and Bioeng. 80 (6) (2002) 599-609.

- R.E.M. Verdurmen, H. Straatsma, M. Verschueren, J.J. van Haren, E. Smit, G. Bargeman, P. de Jong, Modelling spray drying processes for dairy products, Lait 82 (2002) 453-463.

- G. Bargeman, G.H. Koops, J. Houwing, I. Breebaart, H.C. van der Horst, M. Wessling, The development of electro-membrane filtration for the isolation of bioactive peptides. The effect of membrane selection and operating parameters on the transport rate, Desalination 149 (2002) 369-374.

- J. Straatsma, G. Bargeman, H.C. van der Horst, J.A. Wesselingh, Can nanofiltration be fully predicted by a model?, J. Membr. Sci. 198 (2) (2002) 273-284.M. Frank, G. Bargeman, A. Zwijnenburg and M. Wessling, Capillary hollow fiber nanofiltration membranes, Sep. Purif. Technol. 22-23 (2001) 499-506.

- G. Bargeman, M.P.J. Dohmen-Speelmans, I. Recio, M. Timmer and C. van der Horst, Selective isolation of peptides and amino acids with electro-membrane filtration, Lait 80 (2000) 175-185.

\section{Book Chapters}

- G. Bargeman, Separation technologies to produce dairy Ingredients, Chapter 17 in Dairy Processing. Improving Quality, Editor, G. Smit, (2003), 366-390, Woodhead Publishing Limited, Cambridge, UK.

- G. Bargeman, M. Timmer, C. van der Horst, Nanofiltration in the food industry, Chapter 12 in Nanofiltration - Principles and Applications $1^{\text {st }}$ edition, Eds. A.I. Schaefer, A.G. Fane and T. D. Waite, (2005), 305-328, Elsevier Advanced Technologies, Oxford, UK.

\section{Patents and published patent applications}

- G. Bargeman, F.P.F. van Berkel, M.J. den Exter, M.T. de Groot, H.J. Mengers, D.C. Nijmeijer, M.M.A. van Tuel, H.J. Vos, Process for separation methanol and water from non-condensables, EP 2974785 A1

- J.J. Pragt, M.T.G. Jongmans, G. Bargeman, B. Schuur, J.T.J. Aaldering, M.R. Nieuwhof, A.A. Kiss, A.B. de Haan, A. Londono Rodriguez, C.J.G. van Strien, Process for separating monochloro acetic acid and dichloro acetic acid via extractive 
distillation using an organic solvent, BR 112014023076 A1 (granted), CN 104203895 B, EP 2834213 B1, JP2015516960 A1 (granted) and US 9187400 B2.

- A.A. Kiss, J.J. Pragt, M.M. van lersel, G. Bargeman, M.T. de Groot, Continuous process for the preparation of methanol by hydrogenation of carbon dioxide, WO 2013/144041 A1.

- M.T.G. Jongmans, J.J. Pragt, G. Bargeman, B. Schuur, J.T.J. Aaldering, A.B. de Haan, M.R. Nieuwhof, P. Verwer, A.A. Kiss, A.J.B. ten Kate, C.J.G. van Strien, Process for separating monochloroacetic acid from dichloroacetic acid via extractive distillation, BR 112013032034 A1 (granted), CN 103608325 B, JP 5823611 B2, US 9073848 B2 and ZA 201309222 B.

- A.J.B. ten Kate, G. Bargeman, A.M. Koolaard, T. Baks, Process for preparing epichlorohydrin from dichlorohydrin, WO 2011/092270 A2.

- G. Bargeman, R.L.M. Demmer, A. ten Kate, B. Kuzmanovic, C.E.J. van Lare, M.J.J. Mayer, M.A.I. Schutyser, J.B. Westerink, Process to prepare chlorine containing compounds, CA 2598480 C, MX2007010060 A (granted), TWI 429590 B, and US 8038884 B2.

- G. Bargeman, R.L.M. Demmer, A. ten Kate, B. Kuzmanovic, C.E.J. van Lare, M.J.J. Mayer, M.A.I. Schutyser, J.B. Westerink, Process to prepare salt, CA2598339 C, CN101119930 B, EP 1858806 B1, MX2007010061 A (granted), TWI 417244 B, and US 8038883 B2.

- G. Bargeman, R.L.M. Demmer, B. Kuzmanovic, C.E.J. van Lare, M.J.J. Mayer, M.A.I. Schutyser, J.B. Westerink, Method for crystallizing soluble salts of divalent anions from brine, CA 2584969 C, CN 101044091 B, EP 1807349 B1, JP 5166034 B2, and US 7858058 B2.

- G. Bargeman, R.L.M Demmer, A. ten Kate, B. Kuzmanovic, C.E.L. van Lare, M.J.J. Mayer, M.A.I. Schutyser, C.J.G. van Strien, Processes involving the use of antisolvent crystallization, WO06/045795 A2.

- $\quad$ G. Bargeman, R.M. Geertman, A. Giatti, M.J.J. Mayer, R.A.G.M. Bergevoet, Process for preventing membrane degeneration using complexing agents, WO05/121411A2.

- W.J.W. Bakker, R.M. Geertman, M.F. Reedijk, J.J.M. Baltussen, G. Bargeman, C.E.J. van Lare, Antisolvent solidification process, AR 044140 A (granted), CA 2523883 C, CN 100434133 C, EP 1620193 B1, HK1088268 A (granted standard patent), IL 171613 A1 (granted patent), IN 229420 B, JP 5207432 B2, KR 101183046 
B1, MXPA 05011626 A (granted), MY 141189 A (granted), NZ 543772 A (granted), RU 2339364 C2, and ZA 200509597 A (granted).

- P.J. Nieuwenhuizen, M.J.W. Frank and G. Bargeman, Method for removing a nitrogen oxide from a gas, EP 1492611 B1, JP 4427334 B2, and US 7405069 B2.

- E.P. Kieffer, D. Bode, D. Visser and G. Bargeman, Heavy oil conversion process, EP 0400743 B1. 


\section{About the author}

Gerrald Bargeman was born on May 4, 1962 in Groningen, the Netherlands. After finalizing his Master studies in Chemical Technology at the University of Twente in 1986 he worked for approximately twelve years at the Shell Research and Technology Center in Amsterdam and for four and a half years at NIZO food research in Ede in different positions. In September 2002 he joined Akzo Nobel Chemicals B.V., where he worked in different positions in Arnhem and Deventer. Currently, he is employed as Strategic Research Group Leader Process Technology at AkzoNobel Research Development \& Innovation in Deventer, the Netherlands. In combination with his work at AkzoNobel he started as PhD student (under a PNUT contract) at the University of Twente in the Soft Matters, Fluidics and Interfaces group, under the supervision of Prof. M. Wessling in the beginning of 2015. This PhD work, based on research performed at NIZO food research and AkzoNobel has resulted in this dissertation. 


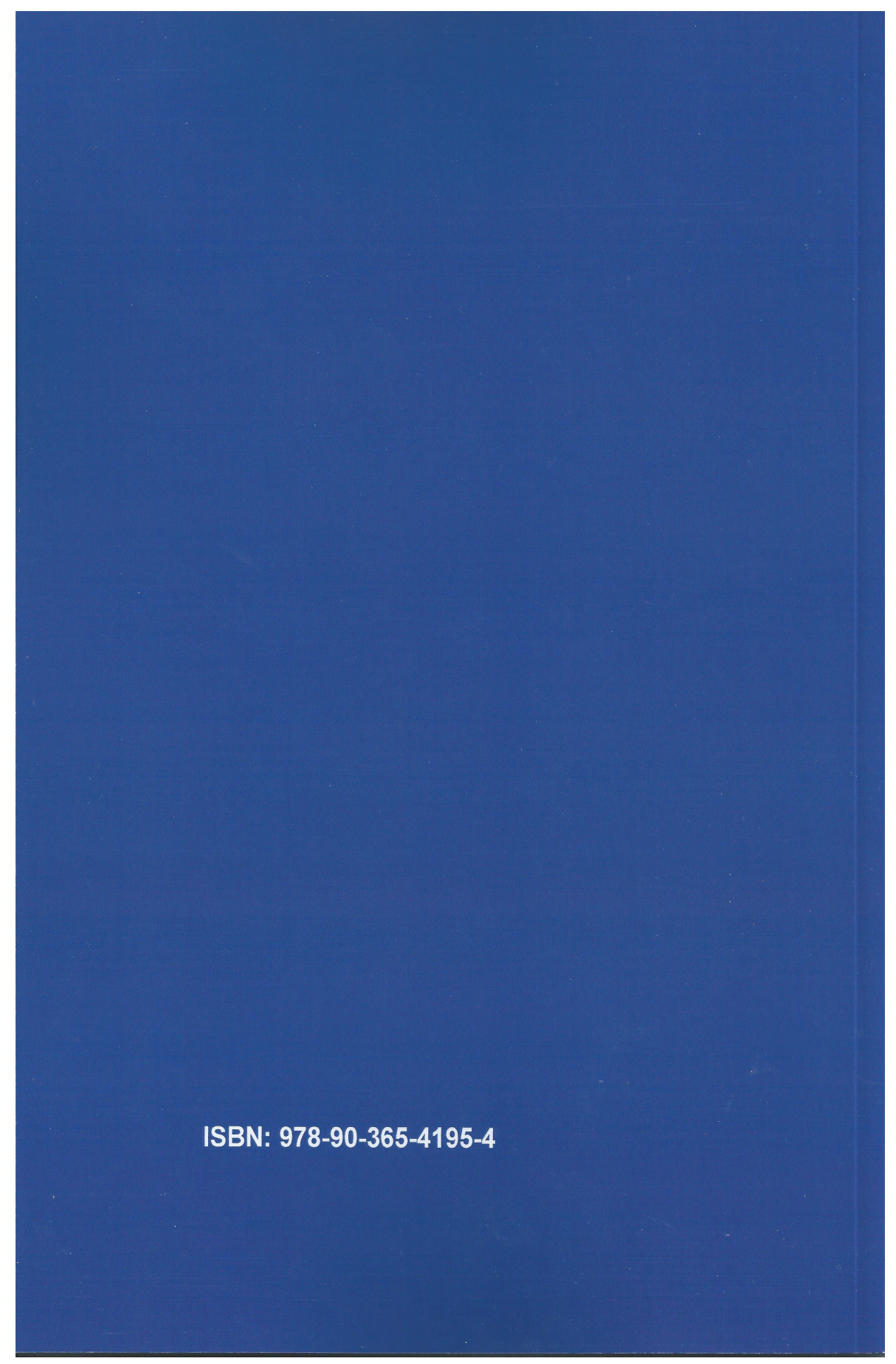

